\title{
ANALYSIS OF STREAMFLOW CHARACTERISTICS FOR STREAMS ON THE ISLAND OF TUTUILA, AMERICAN SAMOA
}

By Michael F. Wong

U.S. GEOLOGICAL SURVEY

Water-Resources Investigations Report 95-4185

Prepared in cooperation with the GOVERNMENT OF AMERICAN SAMOA ENVIRONMENTAL PROTECTION AGENCY, and AMERICAN SAMOA POWER AUTHORITY 


\title{
U.S. DEPARTMENT OF THE INTERIOR BRUCE BABBITT, Secretary
}

\author{
U.S. GEOLOGICAL SURVEY \\ Gordon P. Eaton, Director
}

Any use of trade, product, or firm names in this publication is for descriptive purposes only and does not imply endorsement by the U.S. Government

For sale by the U.S. Geological Survey

Earth Science Information Center

Open-File Reports Section

Box 25286, MS 517

Denver Federal Center

Denver, CO 80225

For additional information write to:

District Chief

U.S. Geological Survey

677 Ala Moana Blvd., Suite 415

Honolulu, HI 96813 


\section{CONTENTS}

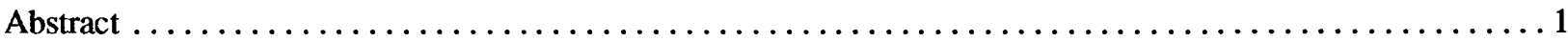

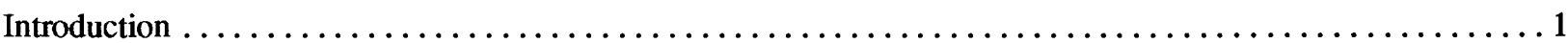

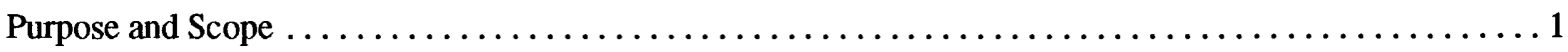

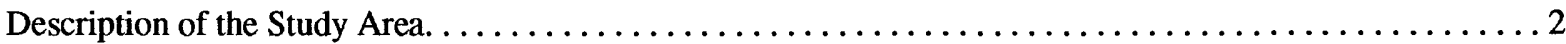

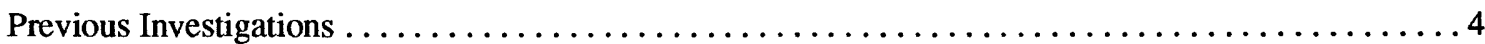

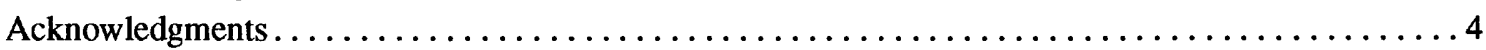

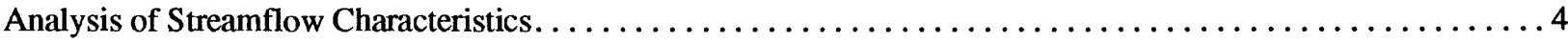

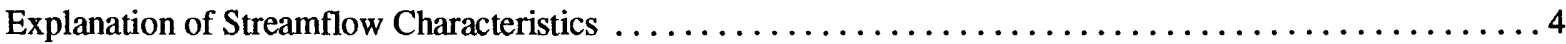

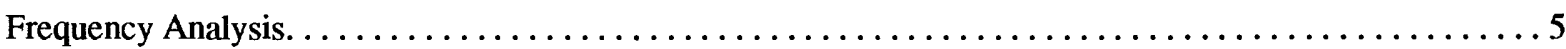

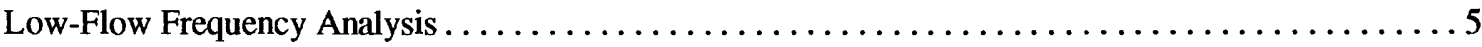

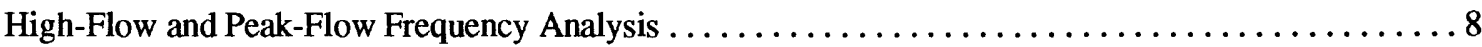

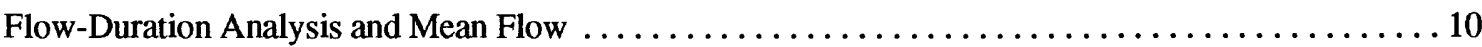

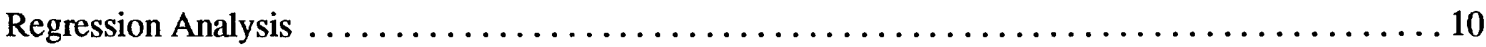

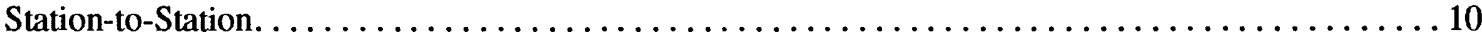

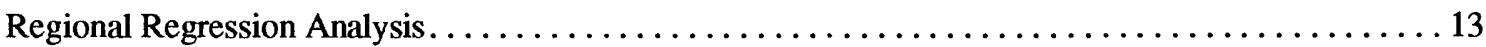

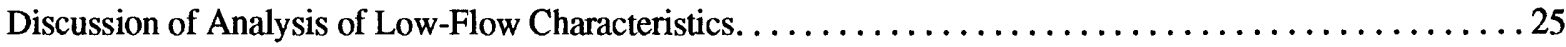

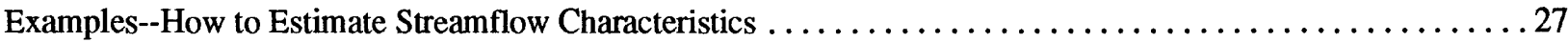

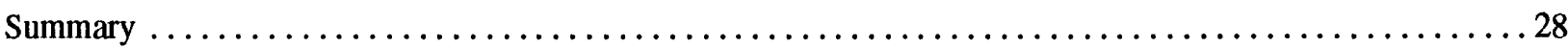

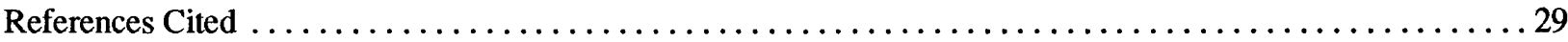

\section{FIGURES}

1-6. Graphs showing:

1. Monthly occurrence of annual peak discharges for the period of record through 1990 for 11 continuous-record stream-gaging stations on Tutuila, American Samoa . . . . . . . . . . . 3

2. Hydrograph of daily discharge of Pago Stream at Afono (station 16912000), for 1988 climatic year, showing annual low-flow periods for various numbers of consecutive days,

Tutuila, American Samoa. . . . . . . . . . . . . . . . . . . . . . . . . . . . . . . . . 6

3. N-day low flow frequency curve for Pago Stream at Afono (station 16912000) for the period of record through 1990, Tutuila, American Samoa $\ldots \ldots \ldots \ldots \ldots \ldots \ldots \ldots \ldots \ldots$

4. Flow-duration curves showing the percentage of time a given flow was equalled or exceeded at Pago Stream at Afono (station 16912000) and Aasu Stream at Aasu (station 16920500) for water years $1960-90$, Tutuila, American Samoa ................ 11

5. Graphical method of estimating low-flow characteristics at sites with eight or more

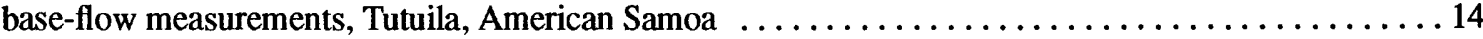

6. Maximum observed flood discharges compared with drainage area and 100-year flood regression line (with bias-correction factor) for gaging stations, Tutuila, American Samoa ........ 23

\section{PLATE}

1. Map showing continuous-record stream-gaging stations, low-flow partial-record stations, miscellaneous sites, and major volcanoes, Tutuila, American Samoa in pocket 


\section{TABLES}

1. Low-flow and high-flow characteristics for continuous-record stream-gaging stations

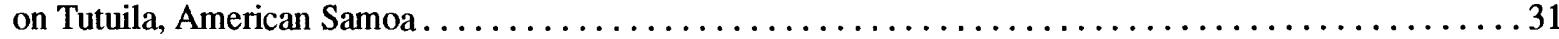

2. Peak flow statistics and estimates for selected recurrence intervals and maximum observed flood discharges at 11 continuous-record stream-gaging stations on Tutuila,

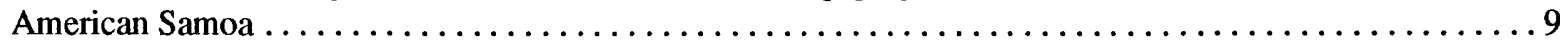

3. Low-flow characteristics for low-flow partial-record stations on Tutuila, American Samoa . . . . . . . . . . 54

4. Low-flow characteristics for miscellaneous sites on Tutuila, American Samoa . . . . . . . . . . . . . . . . . 129

5. Summary of data for continuous-record stream-gaging stations, partial-record stations, and miscellaneous sites used in regional regression analysis, Tutuila,

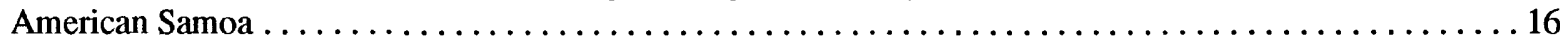

6. Regression equations for estimating low-flow characteristics for ungaged streams in

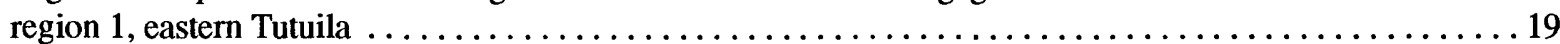

7. Regression equations for estimating low-flow characteristics for streams with some streamflow measurements in region 1, eastern Tutuila, American Samoa ..................... 19

8. Regression equations for estimating low-flow characteristics for ungaged streams in

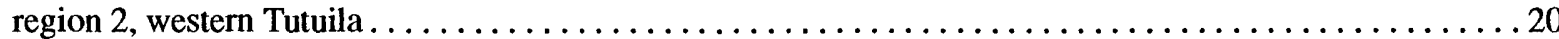

9. Regression equations for estimating low-flow characteristics for streams with some streamflow measurements in region 2, western Tutuila, American Samoa . . . . . . . . . . . . . 20

10. Regression equations for estimating peak flood flows for streams on Tutuila,

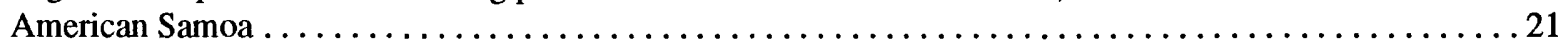

11. Methods available to estimate low-flow characteristics in region 1, eastern Tutuila,

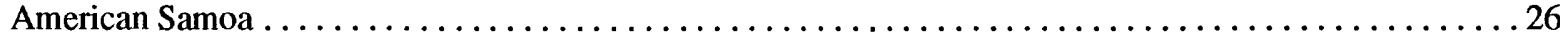

12. Methods available to estimate low-flow characteristics in region 2, western Tutuila,

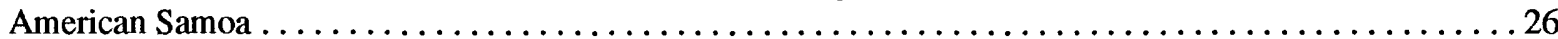

13. Summary of index stations and the number of partial-record stations which used that index station to estimate low-flow characteristics by region, Tutuila, American Samoa . . . . . . . . . . . . 27

\section{Conversion Factors}

\begin{tabular}{rll}
\hline Multiply & By & To obtain \\
\hline foot $(\mathrm{ft})$ & 0.3048 & meter \\
foot per mile $(\mathrm{ft} / \mathrm{mi})$ & 0.1894 & meter per kilometer \\
cubic foot per second $\left(\mathrm{ft}^{3} / \mathrm{s}\right)$ & 0.02832 & cubic meter per second \\
cubic foot per second per square mile $\left(\mathrm{ft}^{3} / \mathrm{s}\right)$ & 0.01093 & cubic meter per second per square kilometer \\
mile $\left(\mathrm{mi}^{2}\right)$ & 1.609 & kilometer \\
square mile $\left(\mathrm{mi}^{2}\right)$ & 2.590 & square kilometer \\
inch per year $(\mathrm{in} / \mathrm{yr})$ & 2.54 & centimeter per year
\end{tabular}




\section{EXPLANATION OF TERMS}

Base-flow--That part of streamflow derived from ground water.

Cubic foot per second $\left(\mathrm{ft}^{3} / \mathrm{s}\right)$-- The rate of discharge representing a volume of 1 cubic foot of water passing a given point during 1 second.

Daily record station--A particular site where gage height measurements are made only once per day.

Drainage area--An area from which streamflow is carried away by a single drainage system. Also called drainage basin.

Continuous-record stream-gaging station--A particular site on a stream where systematic, continuous observations of gage heights, which are subsequently converted to discharge, are obtained.

Index station--A long-term gaging station whose streamflow characteristics are used to estimate characteristics at short-term or low-flow partial-record gaging stations.

Low-flow--The minimum stream discharge that occurs within a given time period.

Low-flow partial-record station--A station where eight or more base-flow discharge measurements are made, typically during a 3 to 4 year period, to determine low-flow characteristics.

Miscellaneous site--A site where discharge measurements have been made as part of studies that were not restricted just to the determination of low-flow characteristics.

Peak flow--The highest instantaneous stream discharge that occurs within a given time period. Used interchangeably with peak discharge.

Recurrence interval--The average interval of time within which a given discharge magnitude will be equaled or exceeded once. Implies no regularity in the time of recurrence. The inverse of recurrence interval can be thought of as the probability of a discharge magnitude being equaled or exceeded in a given year. In the case of lowflow discharges, the recurrence interval is the average interval of time within which the given discharge magnitude is less than or equaled.

Residuals--The difference between the observed and computed values.

Station numbers--Continuous-gaging and low-flow partial-record stations are given eight digit numbers for identification purposes. In this report these numbers are presented as four digit abbreviations such as 9060 , where the complete number for this stations is 16906000 . The two left (16) and two right (00) digits of this and all other station numbers have been omitted in the text of this report for brevity because they are common to all station numbers. 


\title{
Analysis of Streamflow Characteristics for Streams on the Island of Tutuila, American Samoa
}

\author{
By Michael F. Wong
}

\section{Abstract}

Several methods for estimating streamflow characteristics for low and peak flows for streams on Tutuila, American Samoa are presented. These methods, derived from frequency, flow-duration, and regression analyses, allow the user to compute estimates for the 7-day low flow with 2-year and 10-year recurrence intervals; the median flow; the mean flow; and the 2-, 5-, 10-, 25-, 50, and 100year peak flood flows at gaged and ungaged streams. In addition, frequency techniques using the log-Pearson type III distribution were also used to compute for gaged sites the 1-, 7-, 14-, 30-, 60-, 90-, 120-, and 183-day low flows with 2-, 5-, 10-, and 20-year recurrence intervals; the 1-, 7-, 15-, 30day high flows with 2-, 5-, 10-, and 25-year recurrence intervals; and the 2-, 5-, 10-, 25-, 50-, 100year peak flows. The regression equations and estimated streamflow characteristics are based on streamflow data collected from 1958 through 1990 at 11 continuous-record gaging stations with 9 to 32 years of record, 75 low-flow partial-record stations, and 49 miscellaneous sites.

Low-flow regression analysis using the baseflow index basin characteristic provided results with standard errors of estimate ranging from 13.3 to 43.8 percent. These standard errors are comparable to the average values at the low-flow partialrecord stations. Regional analysis, using the method of residuals, divided Tutuila into two hydrologic regions which correspond to differences in geology. Peak-flow regression equations had coefficients of determination ranging from 0.60 to 0.66 and standard errors of estimate ranging from 44.0 to 47.4 percent. The large standard errors result from the large variability of flood peaks compared with drainage area. The geology of Tutuila also affects the magnitude of observed flood peaks.

\section{INTRODUCTION}

The U.S. Geological Survey (USGS) in cooperation with the Government of American Samoa began a systematic stream-gaging program on the island of Tutuila in 1957. Matsuoka (1978) summarized this network of continuous- and partial-record stream-gaging stations. Since 1960, villages and urban centers, located on the flatlands of the island, have become increasingly crowded as Tutuila's population increased from 20,000 in 1960 to 47,000 in 1990 (U.S. Department of Commerce, 1992). The increasing population and development has placed a strain on the water resources of Tutuila. Therefore, this study was undertaken in cooperation with the American Samoa Environmental Protection Agency and the American Samoa Power Authority to provide updated information regarding streamflow characteristics. This information is needed to develop streamflow and drainage standards, to provide water-budget calculations, and to locate potential hydropower and reservoir sites.

\section{Purpose and Scope}

The purpose of this report is to provide updated streamflow characteristics at gaged and low-flow partial-record sites and to describe methods that can be used to estimate streamflow characteristics at miscellaneous and ungaged sites. Streamflow characteristics computed at sites with continuous-record gages include the 1-, 7-, 14-, 30-, 60-, 90-, 120-, and 183-day low flows with 2-, 5-, 10-, and 20-year recurrence intervals; the 1-, 7-, 15-, 30-day high flows with 2-, 5-, 10-, and 25 -year recurrence intervals; the mean flow; flow dura- 
tion; and the 2-, 5-, 10-, 25-, 50-, 100-year peak flows. At low-flow partial-record, miscellaneous, and ungaged sites, the streamflow characteristics evaluated include the 7-day low-flow with 2-year and 10-year recurrence intervals; the median flow; mean flow; and 2-, 5-, 10-, 25-, 50-, 100-year peak flows. Uncertainties in these streamflow characteristics are also evaluated.

This report expands on the work of Matsuoka (1978) who analyzed streamflow characteristics at gaged and low-flow partial-record sites. In the present study, 14 years of additional data are included, low and peak-flow characteristics were regionalized, and updated statistical techniques were applied. Streamflow data collected at 11 continuous-record stream-gaging stations, 75 low-flow partial-record stations, and 49 miscellaneous sites on Tutuila from 1957 through 1990, are used in the analysis. From 1957 through 1958, the USGS operated six daily record stations on Tutuila. These stations are treated as low-flow partial-record stations in this report and are counted in the 75 low-flow partial-record stations. With the exception of a few miscellaneous sites and data from the 1989 and 1990 water years, all data used were published in USGS annual data reports (see Nakahara and others, 1990, as an example) or in Water-Supply Papers (U.S. Geological Survey, 1962, 1971, 1977).

\section{Description of the Study Area}

The island of Tutuila lies in the Pacific Ocean at about latitude $14^{\circ} \mathrm{S}$ and longitude $17^{\circ} \mathrm{W}$ (plate 1). Tutuila has an area of $53 \mathrm{mi}^{2}$ and is the third largest island in the Samoan island chain. Tutuila is the center of government, commerce, and population for the U.S. territory of American Samoa.

Like the other Samoan islands, Tutuila was created by volcanic action and shaped by erosional forces. Four centers of volcanic activity created Tutuila about one million years ago. These centers are, from east to west, the two smaller volcanoes of Olomoana and Alofau, the central Pago Volcano, and the Taputapu Volcano, whose rocks overlap those of the Pago Volcano (Stearns, 1944). Short-lived eruptions, about 12,000 years ago at the summit and south side of Taputapu Volcano, created the Tafuna-Leone plain and blanketed the Taputapu summit with a layer of permeable cinders (P.R. Eyre and G.P.L. Walker, USGS, written commun., 1993). These later eruptions changed the surface runoff characteristics of the Taputapu Volcano. Floods on Tutuila usually are generated in upland areas, where rainfall is high, slopes are steep, and rocks have low permeability; however, the domed summit area of Taputapu, with its blanket of permeable cinders, generates little direct runoff (P.R. Eyre and G.P.L. Walker, USGS, written commun., 1993). The headwaters of streams that radiate from the Taputapu summit are fed by springs that issue from the cinders, resulting in greater sustained base flows than from the other volcanic regions on the island.

The climate of Tutuila is tropical, with uniform temperatures and high humidity throughout the year. Mean annual temperature at the Pago Pago International Airport is $80^{\circ} \mathrm{F}$. Mean daily temperature during the year varies from about $78^{\circ}$ to $82^{\circ} \mathrm{F}$. Most rain falls during the typhoon season from October through April and lower amounts of rain fall in the dry season, from May through September. A compilation of 212 annual peak discharges and dates of occurrence show that 65.5 percent of the annual peaks occur during the wet season (fig. 1). Orographic effects associated with the steep mountain slopes cause rainfall to range from 94 in/yr at the shoreline to $250 \mathrm{in} / \mathrm{yr}$ at the $1,610 \mathrm{ft}$ elevation above Pago Pago Harbor (P.R. Eyre and G.P.L. Walker, USGS, written commun., 1993). Average annual rainfall over the entire island is estimated to be about 150 in/yr (P.R. Eyre and G.P.L. Walker, USGS, written commun., 1993). Rainfall is primarily generated by southeasterly tradewinds bringing moist sea air over the steep mountain slopes or by cyclonic rain associated with ocean storms. Periods of low rainfall, when rainfall at the airport is less than 90 percent of the annual average, recur at roughly 3 to 4 year intervals (P.R. Eyre and G.P.L. Walker, USGS, written commun., 1993). Rainfall was 63 percent of the annual average in 1974, the driest year of record, and 134 percent in 1981, the wettest year of record (National Oceanic and Atmospheric Administration, 1957-88).

Flashy streamflow is characteristic of the small steep-sided drainage basins of the island, whose headwaters meet along the east-west trending central mountain summit of the island (plate 1). Flood hydrographs are steep and of short duration. The rising limb of a typical hydrograph from a gaged stream on Tutuila usually lasts about 1 hour and the recession for about a day to a day and a half. Gaged drainage basins range in area from 0.1 to $1 \mathrm{mi}^{2}$. Most streams on Tutuila are perennial; however, base flows are low and sometimes highly variable (Matsuoka, 1978). 


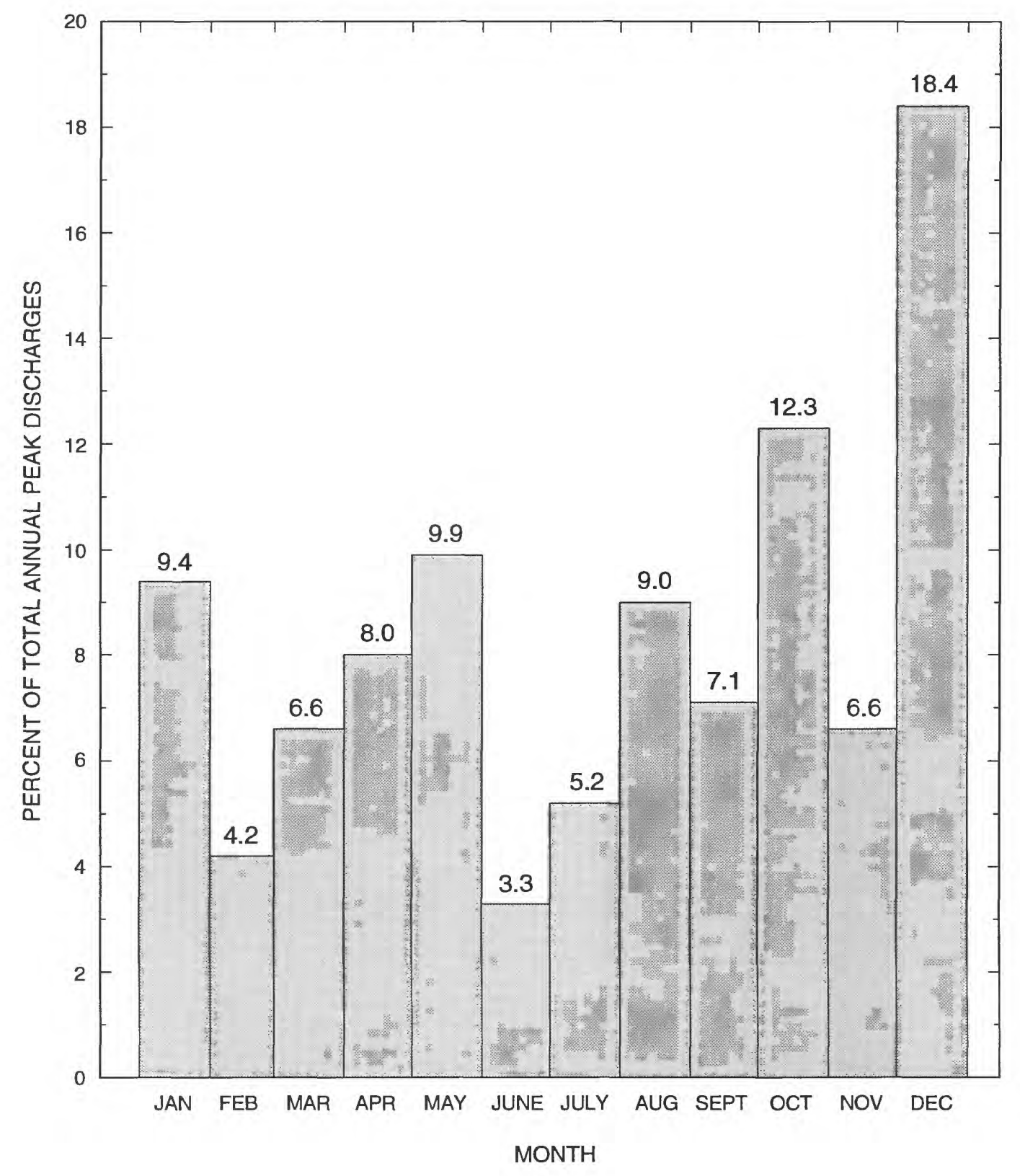

Figure 1. Monthly occurrence of annual peak discharges for the period of record through 1990 for 11 continuous-record stream-gaging stations on Tutuila, American Samoa. 


\section{Previous Investigations}

A study of streamflow characteristics on Tutuila was done by Matsuoka (1978). Matsuoka provided lowand high-flow frequency data and flow-duration curves for 6 continuous-record stations using 18 years of record, from 1959 through 1977, and peak-flow frequency curves for 5 streams with 15 years of continuous streamflow data collected between 1958 and 1973. The low- and high-flow frequency analyses and flow-duration curves were updated through 1977 because of the 1974 drought. All frequency curves were calculated using the log-Pearson type III distribution with station skew coefficients. Matsuoka (1978) also estimated, using regression analysis, the 7-day 2-year and 10-year low flows for 45 of 72 low-flow partial-record stations.

Water-supply studies that discuss low or base flows on Tutuila include Austin, Smith and Associates (1963), R.H. Dale (written commun., 1970), Government of American Samoa (1975), U.S. Army Engineer District, Honolulu (1977, 1978a, 1978b), and M \& E Pacific (1987). The U.S. Army Engineer District, Honolulu (1978b) presented flow-duration curves for six USGS-gaged streams and a "composite" flow-duration curve for regionalization purposes. The U.S. Army Corps of Engineers also conducted some flood hazard studies for a number of streams (Department of the Army, 1976a, 1976b, 1977a, 1977b, 1977c). These studies presented frequency curves computed using methods in Beard (1962) and based on peak-flow data from eight USGS stream-gaging stations. Flood plains for the 100year flood are discussed briefly in U.S. Army Engineer District, Honolulu (1977).

\section{Acknowledgements}

The author gratefully acknowledges the late Folasa Tiumalu, Department of Public Works, Government of American Samoa, the late Falani "Frank" Taotoai, and Asomuamua "John" Ito of the American Samoa Power Authority for their dedicated service in the collection of streamflow data for the USGS.

\section{ANALYSIS OF STREAMFLOW CHARACTERISTICS}

This section describes the analytical methods used to determine streamflow characteristics and the results from applying these methods. These methods are frequency analysis, flow-duration and mean flow analysis, and regression analysis. The use of each method was dependent on the location and type of site and the quality and quantity of data available. Discussions of streamflow characteristics, the available data, and the computation of streamflow characteristics by the various methods are presented. It is assumed that readers have a familiarity with basic statistical procedures and with statistical methods in hydrology as discussed by Riggs (1968a, 1968b, 1973).

\section{Explanation of Streamflow Characteristics}

Natural streamflow is highly variable and dependent on the geology, climate, and topography of a given region. Streamflow characteristics are quantitative measures of the magnitude, variability, and extremes of instantaneous, daily, monthly, and yearly means of streamflow (Riggs, 1985). Most streamflow characteristics are usually categorized as either low- or high-flow characteristics.

Low-flow characteristics include the 7-day 2- and 10-year low flows, the median flow, and the mean flow. The 7-day 2- or 10-year low flow is the discharge at the 2- or 10-year recurrence interval measured from a frequency curve developed for a gaging station using the lowest mean discharge for 7 consecutive days for each year. The minimum mean discharge for 7 consecutive days within a given year will equal or fall below the 7day 2- or 10-year low flow on average once every 2 or 10 years. In any given year, the probability of this happening is one-half ( 50 percent) for 2-year recurrence intervals and one-tenth ( 10 percent) for 10 -year recurrence intervals. This same general definition applies to the 1-, 7-, 14-, 30-, 60-, 90-, 120-, and 183-day low flows with 2-, 5-, 10-, and 20-year recurrence intervals. The 7-day 2-year low-flow value usually represents the normal low flow that would be expected each year. The 7-day 10-year low-flow value represents a measure of extreme low-flow conditions commonly associated with droughts. Riggs (1985) mentions that the severity of a seasonal drought can be expressed by the recur- 
rence interval associated with the minimum 30-day mean low flow at a gaging station. The 7-day 10-year low flow is also used as a design flow for water-quality management by many states in the United States. The median flow represents the flow that is equaled or exceeded 50 percent of the time at a given stream site. The median is estimated from a flow-duration curve. A flow-duration curve is a cumulative frequency curve that shows the percentage of time that a daily mean flow equals or exceeds a given discharge (Searcy, 1959). The median flow is used in hydropower studies as an index of power potential with storage (Searcy, 1959). The median flow is also used to regulate streamflow allocation in the State of Hawaii. The mean flow is the mean of all daily recorded streamflows at a gaged site. The mean flow represents the long-term average flow that would be observed at a given site. The mean flow has been used in the calculation of streamflow resources for water-budget and ground-water recharge studies.

High-flow characteristics include the instantaneous peak flows with 2-, 5-, 10-, 25-, 50, and 100-year recurrence intervals and the 1-, 7-, 15-, 30-day high flows with 2-, 5-, 10-, and 25-year recurrence intervals. Instantaneous peak flows with recurrence intervals of 2-, 5-, 10-, 25-, 50-, and 100-years are peak-flow discharges expected to be equalled or exceeded once on average every $2,5,10,25,50$, and 100 years, respectively. The 30 -day high flow with a 10 -year recurrence interval is the average discharge for a 30-consecutiveday period expected to be equalled or exceeded once on average every 10 years. This same general definition applies to the 1-, 7-, and 15-day high-flow values. Peak flows are used in the design of bridges, culverts, and other structures to prevent flood damages. The Federal Emergency Management Agency (FEMA) uses the 100-year peak flood to estimate the extent of flood plains for flood insurance studies. Peak flows, along with the consecutive-day high and low flows, also are used in the design and management of dams and reservoirs.

\section{Frequency Analysis}

In a frequency analysis, a theoretical frequency distribution is assumed for the population of streamflow events and the statistical parameters of this distribution are computed from the collected streamflow data. The resulting frequency curve relates the magnitude of a streamflow event to the frequency of occurrence
(Riggs, 1968b). Frequency analysis was conducted on annual series of low-flow, high-flow and peak-flow characteristics for the continuous-record stream-gaging stations on Tutuila. The proper interpretation of frequency curves requires that the data set used consist of homogeneous and independent streamflow events. Thus, the use of annual series.

\section{Low-Flow Frequency Analysis}

For low-flow frequency analysis, an annual series of low flows were calculated by climatic year (April 1 through March 31). The climatic year was used to ensure that the entire low-flow cycle (usually May through September) was maintained as a continuous period within a given year. The annual series of 1-, 7-, 14-, 30-, 60-, 90-, 120-, and 183-day low flows were determined as the lowest mean discharge for that number of consecutive days within each climatic year of record as shown in figure 2. Proper analysis of low-flow frequency data requires that a representative sample of the type of streamflow data involved be available. Given the 3 to 4 year cycle of wet and dry years on Tutuila (P.R. Eyre and G.P.L. Walker, USGS, written commun., 1993), a minimum of 9 to 12 years of streamflow data are required to provide a representative sample. Of the 11 stream-gaging stations on Tutuila, only 7 had at least 9 continuous climatic years of record. For these 7 stations, the low-flow frequency characteristics were determined using the log-Pearson type III distribution with graphical adjustment for fit if necessary (Riggs, 1972).

The log-Pearson type III is a three-parameter distribution. These parameters are the mean, standard deviation, and coefficient of skew computed from the logarithms of the annual series of low-flow data by the method of moments. As a result, these parameters are also called moments (the mean is the first moment, the standard deviation is the second moment) (Kite, 1977). USGS computer program A193 in ANNIE (Lumb and others, 1990) was used to compute the frequency curves. Examples of frequency curves are shown in figure 3.

Results of the low-flow frequency analysis are given in table 1 (at end of report). For two stations, 9060 and 9480, diversions were significant enough to prevent using their entire data sets for frequency analysis. A significant diversion is one where the streamflow diverted has a noticeable effect on the observed streamflow 


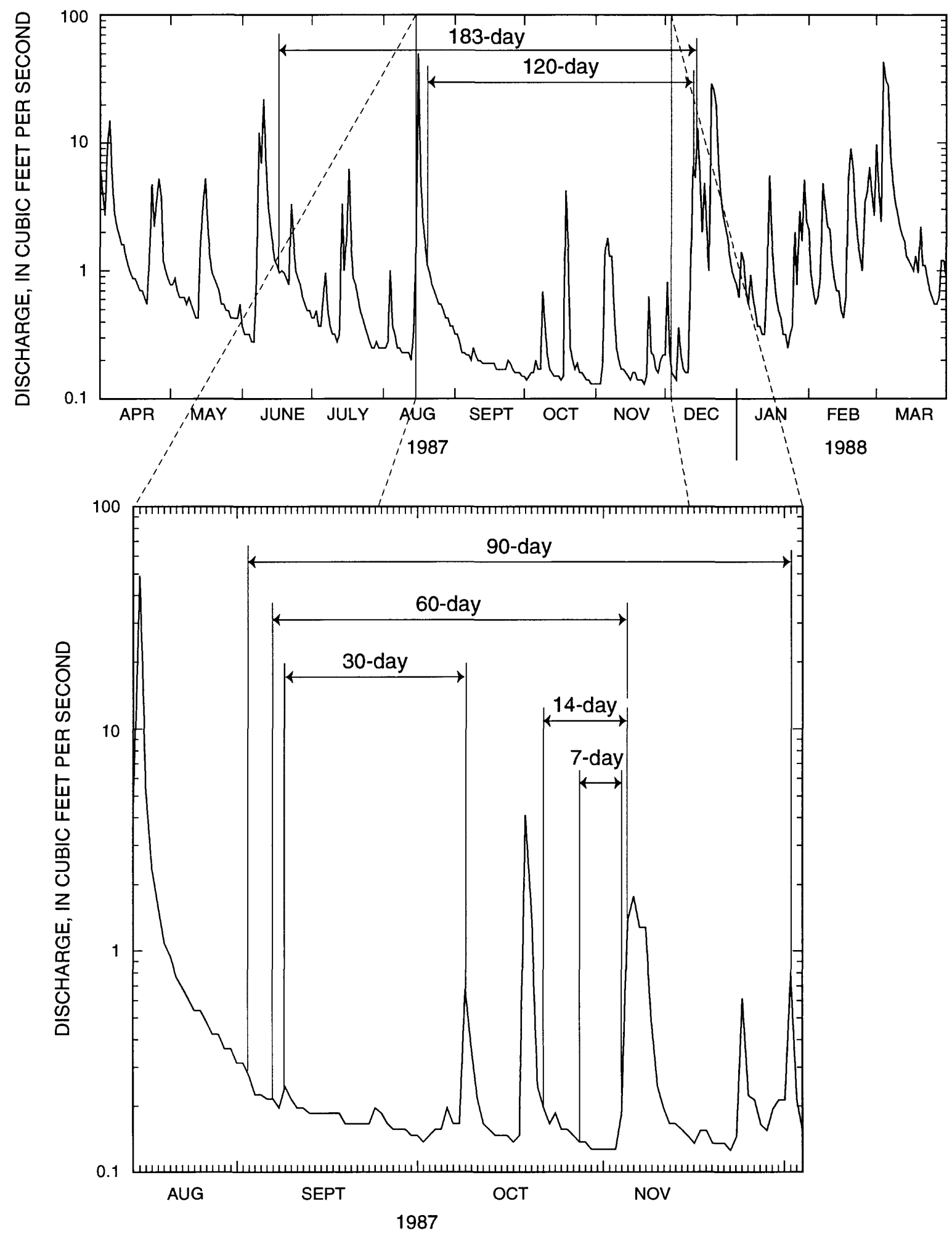

Figure 2. Hydrograph of daily discharge of Pago Stream at Afono (station 9120), for 1988 climatic year, showing annual low-flow periods for various numbers of consecutive days, Tutuilla, American Samoa. 


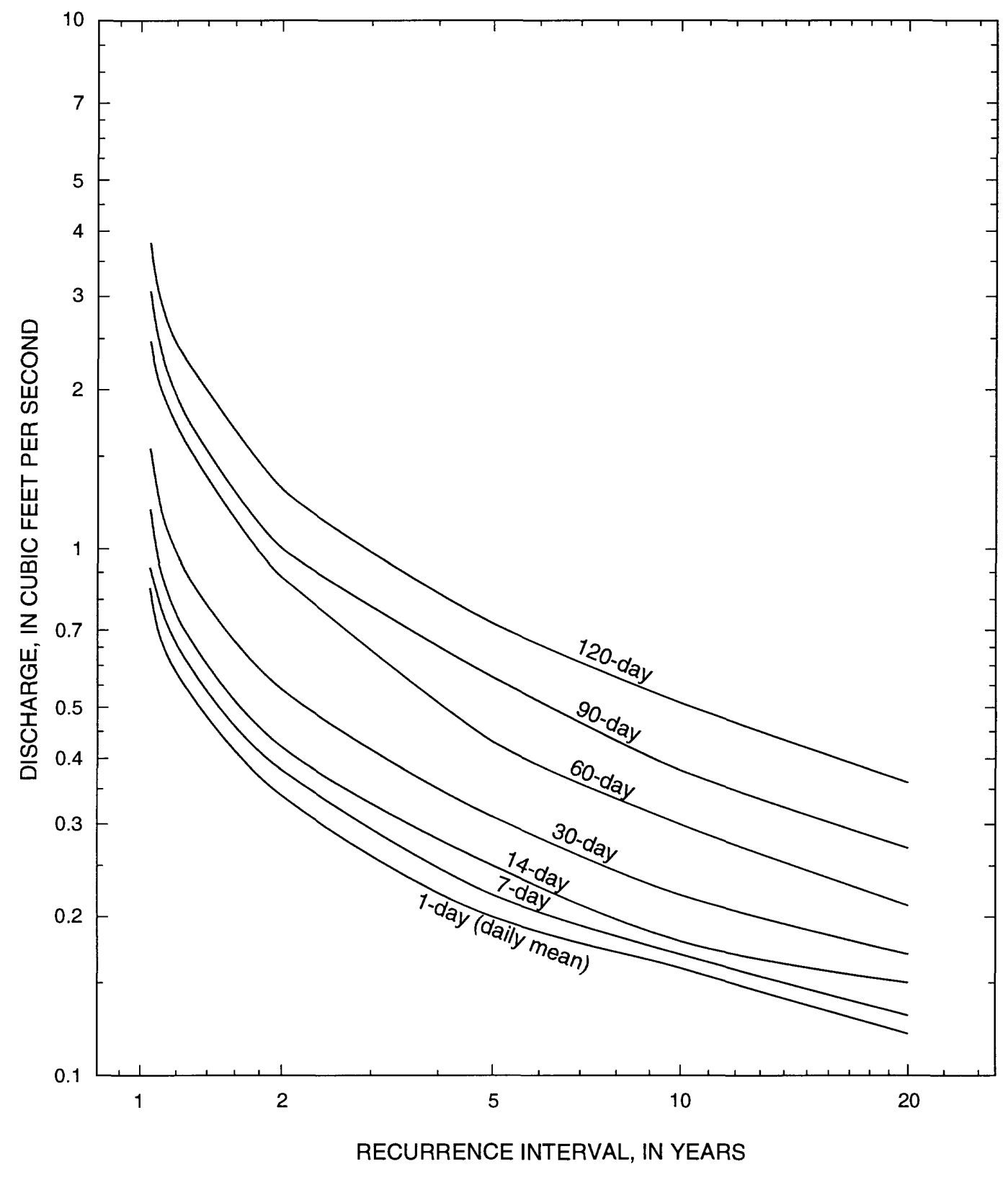

Figure 3. N-day low-flow frequency curves for Pago Stream at Afono (station 9120) for the period of record through 1990, Tutuila, American Samoa. 
compared to the streamflow prior to the diversion. For station 9060, the average annual median flows were reduced by 30 percent from pre-diversion flows; at station 9480 , the reduction was 48 percent. Since the proper interpretation of frequency curves requires homogeneous data sets, only one data set could be used, either the preor the post-diversion data set. At station 9060, the postdiversion data set was too short to provide a good representation. At station 9480 , only the 17 climatic years of post-diversion data were used to compute the frequency curves. For the four stations $(9060,9315,9335$, and 9442) with insufficient data for low-flow frequency analysis, low-flow characteristics were estimated by the station-to-station regression procedures described below. Locations of continuous-record stream-gaging stations are shown in plate 1.

Accuracy of the 7-day 2- and 10-year low flows at continuous-record stream-gaging stations was determined by the method developed by Hardison and Moss (1972). This method computes standard error as a function of the standard deviation of the logarithms of the annual low flows, the coefficient of skew of the same annual series, the recurrence interval, and the number of years of record at the gaging station. This method could also be used to compute accuracies for the other lowflow and high-flow frequency values. Only the accuracies for the 7-day 2- and 10-year low flows are given in table 1.

\section{High-Flow and Peak-Flow Frequency Analysis}

A high-flow frequency analysis is similar to lowflow frequency analysis but uses the available highflow data instead of low-flow data. The log-Pearson type III frequency distribution was used with the annual series of 1-, 7-, 15-, and 30-day high flows. The annual series of 1-, 7-, 15-, and 30-day high flows were determined as the highest mean discharge in the year for that number of consecutive days. For high- and peak-flow analyses, the year used is the water year (October 1 through September 30). High-flow frequency characteristics were calculated for the 10 continuous-record stream-gaging stations with 9 or more water years (October 1 to September 30) of record (table 1). No highflow characteristics were computed for station 9442 , which had only 8 years of daily flow record. USGS computer program A193 in ANNIE (Lumb and others, 1990) was used to compute the high-flow frequency curves as well.

For peak-flow frequency analysis, the log-Pearson type III distribution was applied to the annual series of instantaneous peak discharges following procedures outlined in Bulletin 17B (Interagency Advisory Committee on Water Data, 1982). Bulletin 17B procedures recommend the skew coefficient at each gaging station be weighted with a generalized skew, which is determined from long-term records from several gaging stations. Because the skew coefficient is sensitive to the magnitude of rare events such as large floods, the station skew for a short-term record is generally a poor estimate of the population skew. The use of a generalized skew provides for an improved skew estimate at shortterm stations. No previous value of generalized skew exists for Tutuila, so one was calculated by taking the arithmetic mean of skew values, as discussed in Bulletin 17B (Interagency Advisory Committee on Water Data, 1982), from the four long-term continuous-record stream-gaging stations having more than 30 years of record. To calculate the generalized skew, the station skew coefficients were multiplied by a bias-correction factor of $(1+8.5 / \mathrm{N})$, where $\mathrm{N}$ is the number of years of record. This bias-correction factor was proposed by Hazen (1930, p. 46) and used by Hardison (1974) to compensate for the low bias exhibited by skew coefficients of data from records of finite length. Hazen's (1930) correction factor was chosen over others (for example, that of Tasker and Stedinger, 1986) because its applicability is not limited by the range of skew values or record lengths. After the bias adjustment, the mean skew for the four long-term stations $(9120,9205,9310$, and 9480 ) was determined to be -0.4 with a variance of 0.291 .

Flood-frequency curves were estimated using the -0.4 generalized skew in USGS program J407, which uses Bulletin 17B guidelines and is located in WATSTORE (Kirby, 1979) and in ANNIE (Lumb and others, 1990). Table 2 gives the peak-flow statistics from the logarithms of the annual floods and the magnitude and frequency of floods at the 11 continuous gaging stations on Tutuila with recurrence intervals of 2-, 5-, 10-, 25-, 50-, and 100-years. Accuracy of high-flow estimates are dependent on the same factors as low-flow frequency estimates. Accuracy of peak-flow estimates also are dependent on the same factors as low-flow frequency estimates with the addition of the correlation between the mean and standard deviation of the annual series of peak discharges. Accuracies for the high-flow and peak-flow estimates are not provided in this report, but can be computed by the methods in Hardison and Moss (1972) and Hardison (1969, 1971). 


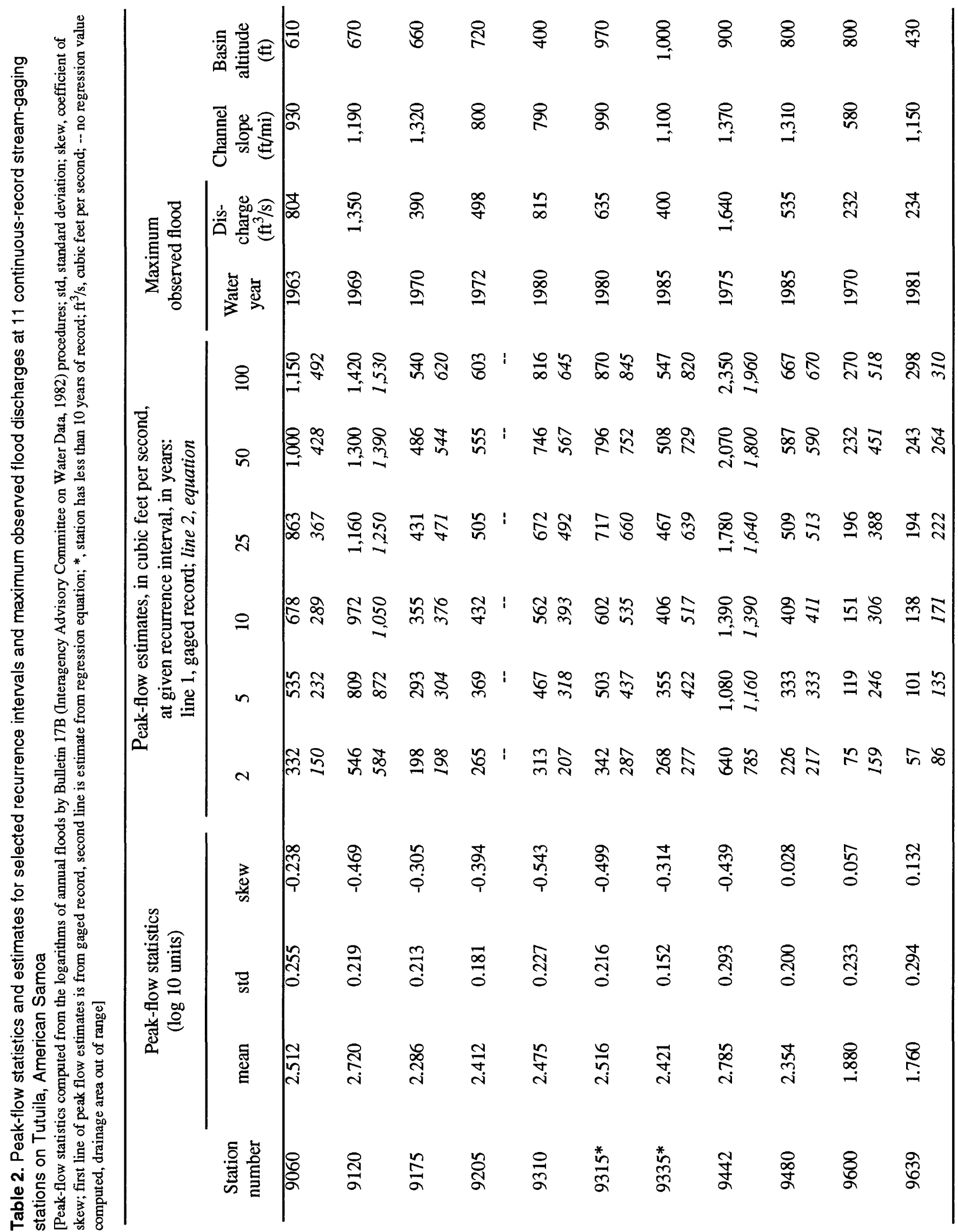




\section{Flow-Duration Analysis and Mean Flow}

Flow-duration analysis uses all the daily mean discharges for complete water years for the entire period of record to compute a flow-duration curve. A flow-duration curve indicates the percentage of time that a given discharge is equalled or exceeded. Examples of flowduration curves are shown in figure 4 . The median flow is the flow equalled or exceeded 50 percent of the time. Flow-duration curves were computed by the method in Searcy (1959) and results are tabulated for all 11 stream-gaging stations in table 1. For two stations, 9060 and 9480 , the low-flow data were affected by diversions so that flow-duration curves are given for both the preand post-diversion time periods. USGS computer program A969 in WATSTORE was used to compute the flow-duration curves (Meeks, 1975).

Flow-duration curves imply no frequency of events and comparisons of flow-duration values between gaging stations require that the duration curves be computed from discharge data covering the same time period. Included with the flow-duration data in table 1 is an index of variability. This index is computed from the flow-duration curve (Searcy, 1959) and may be used to explain ground-water effects on streamflow. A high value of variability indicates a steep slope of the flow-duration curve, high variability of streamflow, and low ground-water storage (Searcy, 1959; Friel and others, 1989). A low value of variability indicates a greater ground-water storage capacity, which maintains higher sustained streamflow during dry periods (Friel and others, 1989). The index of variability for the 11 continuous-gaging stations ranged from 0.265 to 1.04 (table 1).

The mean flow is the average of all the daily discharges recorded at a given station for the period of record. Mean flow values are given at all gaging stations for the period of record through 1990 (table 1), except for stations 9060 and 9480 . Because of the upstream diversions of streamflow at these stations only the mean flow discharges from the post-diversion period are given. The large differences between median and mean streamflow characteristics observed for streams on Tutuila can be attributed to the flashy nature of the streams.

The mean and median values are computed without error for a given period of record. Accuracies of the true, or long-term, value of the mean and median flows were estimated by equations in Kendall and Stuart
(1963). The accuracies given in table 1 for the mean and median are those for the true or long-term value of the mean and median.

\section{Regression Analysis}

Because streamflow records are collected at only a few of the many sites where information is needed, streamflow characteristics commonly are estimated at low-flow partial-record, miscellaneous, and ungaged sites using information obtained from gaged sites. Regression analysis is a tool allowing the transfer of data from one site to another. Regression analysis is used to describe a relation using either streamflow measurements or basin characteristics. From this relation, streamflow characteristics can be transferred. In this report, regression analysis was used to transfer low-flow characteristics from a gaged site to other gaged sites, low-flow partial-record sites, and some miscellaneous sites and to relate selected streamflow characteristics to basin characteristics so that the selected streamflow characteristics can be transferred to low-flow partialrecord, miscellaneous, and ungaged sites.

\section{Station-to-Station}

Station-to-station regression analysis was used to transfer low-flow characteristics from continuousrecord index stations to sites with 8 or more base-flow measurements. These sites can include continuousrecord, low-flow partial-record, and miscellaneous sites. The relation between data at sites with base-flow measurements and mean daily flow at index stations was determined by one of two different methods: the moments approach or graphical regression. The selection of method was dependent on the number of measurements available and the strength of the linear relation, as determined by the correlation coefficient, between the site and its index station. The correlation coefficient measures the degree of linear relation between two variables and varies from -1 to 1 , with values close to -1 and 1 indicating strong linear relationships. The negative sign indicates an inverse relation. For sites with 10 or more base-flow measurements, a correlation coefficient greater than 0.70 , and a linear relation, the moments method was used. At sites with fewer than 10 measurements and/or sites with non-linear relations, the graphical regression, also called graphical correlation, method was used. Sites with data that correlated poorly with data from index stations (correlation coefficient 


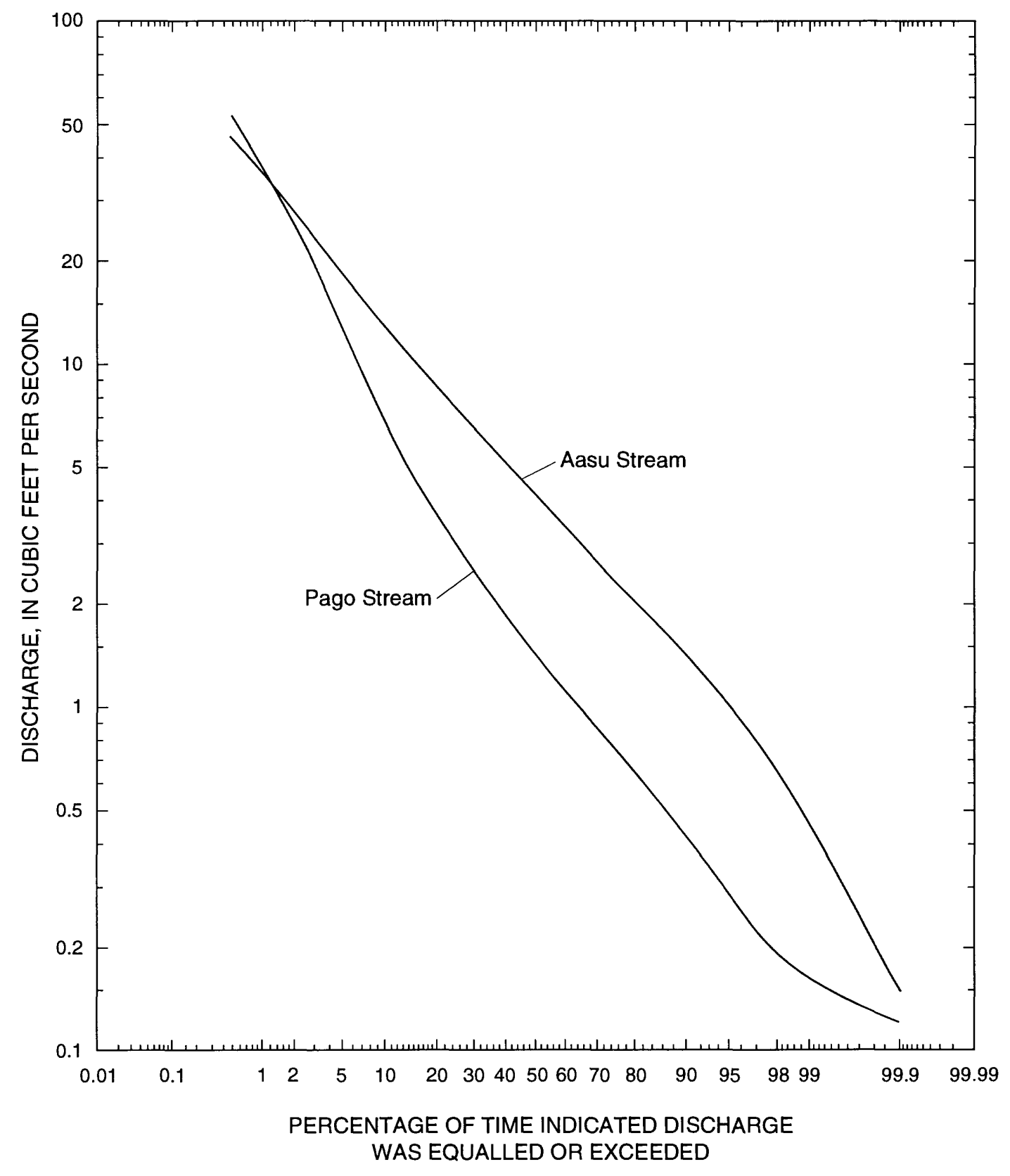

Figure 4. Flow-duration curves showing the percentage of time a given flow was equalled or exceeded at Pago Stream at Afono (station 9120) and at Aasu Stream at Aasu (station 9205), for water years 1960-90, Tutuila, American Samoa. 
less than 0.50) and/or seven or fewer measurements were treated as miscellaneous sites. All discharge data were normalized by logarithmic (base 10) transformation before analysis (Searcy, 1960). The logarithmic transformation commonly creates a linear relation among streamflow data. The index station with concurrent daily discharges having the highest correlation coefficient with the base-flow measurements for a site, regardless of method, was selected as the index station for that particular site.

Some low-flow partial-record stations have measurements that include surface runoff. In some cases surface runoff was occurring at the index station on the days when discharge measurements were made at the low-flow partial-record stations. Only base-flow data were used to determine the relation in either the moments approach or the graphical correlation method. Therefore, streamflow measurements which included surface runoff were not used in the low-flow analysis.

Of the seven continuous-record gaging stations with computed low-flow frequency curves, only five had periods of record long enough to cover the dates of the base-flow measurements at the remaining four continuous-record stations, the low-flow partial-record stations, and the miscellaneous sites. The five gaging stations $(9120,9205,9310,9480$, and 9600) were used as index stations in the analysis. Two different sets of low-flow characteristics from station 9480 were used for transferring. When most of the base-flow measurements at the partial-record and miscellaneous sites were made during the pre-diversion time period at station 9480 , then low-flow characteristics computed for the pre-diversion base-flow period were used. When most of the base-flow measurements were made during the post-diversion time period at station 9480 , the post-diversion characteristics were used.

Moments approach.--The moments approach is a mathematical method that transfers the parameters of a frequency curve (the moments) from an index station to a site with base-flow measurements. This method is discussed in detail by Stedinger and Thomas (1985) and briefly explained here. Because the moments approach is a mathematical method, a large number of base-flow measurements and a high correlation coefficient are needed to provide reliable results. The moments approach uses ordinary least-squares regression analysis to describe the relation between the index station and the site with base-flow measurements. The site with base-flow measurements is assumed to have the same coefficient of skew as the index station and the other moments (mean and standard deviation) are then transferred using the regression line. A frequency curve is then created at the site with base-flow measurements using the transferred moments. The 7-day 2-year and 10 -year low flows are calculated from this curve. For sites where this approach was used, the median and mean flows were transferred using the same regression line. The moments approach can be used with one or two index stations and provides results comparable to estimates computed by frequency analysis when applied to data from continuous-record gaging stations on Tutuila.

The regression equation used in the moments approach simply relates the streamflow measurements at the continuous-record, low-flow partial-record, or miscellaneous site to the daily mean streamflow at the index station and has the form:

$$
\log Q=\log a+b_{1} \log X_{1}+b_{2} \log X_{2},
$$

where:

$\log Q=$ logarithm of streamflow at site with base-flow measurements,

$\log X_{1}, \log X_{2}=\operatorname{logarithm}$ of daily mean streamflow at index stations,

$a=$ the regression constant, and

$b_{1}, b_{2}=$ the regression coefficients.

The moments also in logarithmic format are then transferred using equation 1 . For the mean and median streamflow characteristics, the regression equations were untransformed from logarithms, and have the form:

$$
Q=a\left(X_{1}^{b_{1}}\right)\left(X_{2}^{b_{2}}\right)(\mathrm{BCF})
$$

where:

$Q=$ streamflow at site with base-flow measurements,

$X_{1}, X_{2}=$ streamflow at index stations,

$a=$ the regression constant,

$b_{1}, b_{2}=$ the regression coefficients or exponents of the streamflow characteristics at the index stations, and

$\mathrm{BCF}=$ the bias-correction factor.

The bias-correction factor is used to correct for re- 
transformation bias that results when the logarithmic transformation is used (Miller, 1984). In this study the bias-correction factor was determined by the "smearing estimate" (Duan, 1983). Bias-correction factors were applied to the regression constants when determining the mean streamflow characteristics. Median streamflow estimates were not corrected because no bias was shown when moments approach was applied using data from continuous-streamflow stations. Bias-correction factors for the 45 low-flow partial-record sites using the moments approach ranged from 1.012 to 1.333 and had an average of 1.082 .

Graphical regression.--The graphical regression or graphical correlation method is discussed in detail by Searcy (1960) and also by Hardison and Moss (1972). This method consists of plotting the base-flow measurements for the continuous-record station, low-flow partial-record station, or miscellaneous site against the concurrent daily discharges for the index station on logarithmic graph paper. A line which best fits the given data is then drawn through the data. This is the line of relation. Low-flow characteristics are then transferred from the index station to the site with base-flow measurements by using the line of relation and the low-flow characteristics for the index station. An example of this procedure is provided in figure 5.

Low-flow estimates.--Estimates of the 7-day 2and 10-year low flows at the 4 continuous-record stations $(9060,9315,9335,9442)$ using station-to-station methods are given in table 1 (at end of report). At some of these continuous-record stations, daily mean flows or annual 7-day low-flow values were used in place of base-flow measurements in the above methods. Estimates of the 7-day 2- and 10-year low flows, median flows, and mean flows for 73 of the 75 low-flow partialrecord stations are given in table 3 (at end of report). Locations of low-flow partial-record sites are shown in plate 1 . The two partial-record stations without estimates for low-flow characteristics were daily record stations 9500 and 9505 (old) which measured a municipal diversion and have been excluded from further analysis. Only 4 of the 49 miscellaneous sites had eight or more discharge measurements. These sites $(2,43,44$, and 46) had low-flow characteristics estimated by the methods described above and are presented in table 4 (at end of report). The remaining miscellaneous sites had low-flow characteristics estimated by using the regional regression equations discussed in the section of the re- port on "Regional regression analysis."

Accuracy of the low-flow characteristics for continuous-record stations, low-flow partial-record stations, and miscellaneous sites were computed using methods summarized by Stedinger and Thomas (1985) and Hardison and Moss (1972). The method by Stedinger and Thomas (1985) is a modification to the method by Hardison and Moss (1972) and applies only to sites where the low-flow characteristics were computed by the moments approach. Accuracy estimated using either method is dependent on the number of base-flow measure-ments at the site, the variance of these measurements, the magnitude of the 7-day 2- or 10-year estimate relative to the base-flow measurements, and the standard error of the 7-day 2- or 10-year low flow at the index station.

\section{Reglonal Regression Analysis}

Regional regression analysis relates the streamflow characteristics to measurable basin characteristics. The resulting regression equation can then be used to estimate streamflow characteristics at any site using the basin characteristics from that site.

The ordinary least-squares estimator used in traditional regression analysis, such as that applied in using the moments approach, assumes that the errors (residuals) are random, uncorrelated, normally distributed, and have equal standard deviations (Draper and Smith, 1981). Therefore, all stations used in the regression analysis are given equal weight. However, these conditions are not always met with regional hydrologic data because streamflow records at gaged sites used in the regression analysis are of different record lengths. In addition, cross-correlation of concurrent flows among nearby gaged sites can exist especially when using lowflow characteristics from partial-record stations. To solve these problems, Stedinger and Tasker (1985) developed a generalized least-squares estimator that accounts for cross-correlation among sites as well as for unequal record length. The generalized least-squares estimators assign each station a different regression weight and therefore improve model accuracy. Where the ordinary least-squares assumptions were violated it has been shown that generalized least-squares estimators are appropriate for certain situations and provide reduced standard errors of estimate for the regression equations (Stedinger and Tasker, 1985). 


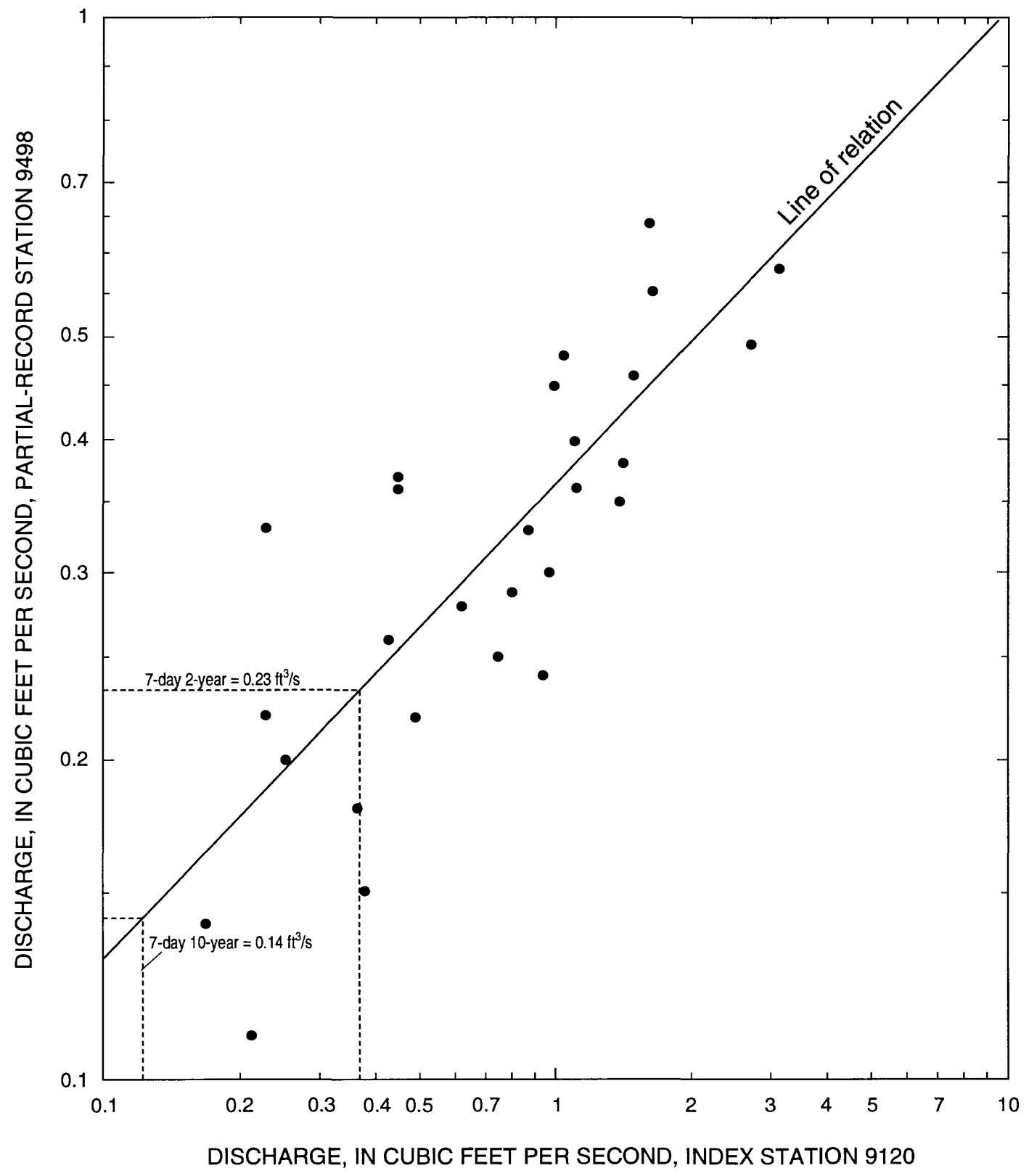

Figure 5. Graphical method of estimating low-flow characteristics at sites with eight or more base-flow measurements, Tutuila, American Samoa. 
For the regression analysis in this study, the 7-day 2- and 10-year low flows, the median flow, the mean flow, and the peak flood estimates for the 2-, 5-, 10-, 25-, 50-, and 100-year recurrence intervals were the dependent variables and the drainage-basin characteristics were the independent variables. For the low-flow characteristics, regression analysis was done using the baseflow index basin characteristic to compute equations that are applicable for sites with some base-flow data and without the base-flow index variable to produce equations for ungaged sites. Data for sites having significant upstream diversions were excluded, leaving 81 out of 88 stations and miscellaneous sites available for regression analysis (table 5). Data for the regional regression analysis were also transformed using the common (base 10) logarithm. This transformation was based on examination of the streamflow, basin, and climatic characteristics and results from previous studies (Thomas and Benson, 1970) which have shown that the logarithmically transformed variables are linearly related.

After transforming the variables, the first step of the regional regression analysis was to determine the significant independent variables for each of the streamflow characteristics. This was done by using correlation and stepwise regression procedures. Correlation was used to calculate the degree of correlation between the dependent and independent variables, and between all pairs of independent variables. Because high correlation between two independent variables tends to reduce the statistical significance of each variable involved in regression analysis, only the more significant and reliable one was retained.

The stepwise regression procedure was used to determine the most statistically significant independent variables. In this procedure, variables are added or deleted one at a time into the regression model according to their level of significance for entry and retention (Draper and Smith, 1981). In this study, an entry and retention significance level of 0.05 ( 5 percent) was used in the stepwise regression F-test to limit the number of variables. Also, the use of the 5-percent significance level generally limited the final regression equations to two or three variables. The stepwise procedure was run for each streamflow variable using data for the entire island and for each of the individual regions that were later identified.

In choosing variables and regions, a study of the standard error of estimate in percent (\%SE) and the co- efficient of determination $\left(\mathrm{R}^{2}\right)$ was done on the stepwise regression results. The \%SE is the measure of model error and lack of fit of the regression equation and the $R^{2}$ is the fraction of the total variability of the observed dependent variables explained by the independent variables. For multiple regression analysis the $\mathrm{R}^{2}$ is adjusted for lost degrees of freedom caused by multiple independent variables (Draper and Smith, 1981). In general, use of statistically significant predictor variables minimized the \%SE and maximized $\mathrm{R}^{2}$. The chosen variables were then used to develop the regression equations. The resulting regression equations have the form:

$$
Q=a\left(x_{1}^{b_{1}}\right)\left(x_{2}^{b_{2}}\right) \ldots\left(X_{n}^{b_{n}}\right)(\mathrm{BCF})
$$

where:

$$
\begin{aligned}
Q= & \text { streamflow characteristic (dependent } \\
& \text { variable), } \\
X_{1}, X_{2}, \ldots X_{\mathrm{n}}= & \text { basin and/or climatic characteristics } \\
& \text { (independent variables), } \\
a= & \text { the regression constant, } \\
b_{1}, b_{2}, \ldots b_{n}= & \text { the regression coefficients or exponents } \\
& \text { of the basin and/or climatic } \\
& \text { characteristics, and } \\
\mathrm{BCF}= & \text { the bias-correction factor. }
\end{aligned}
$$

The bias-correction factor is the same as explained under equation 2. Bias-correction factors were applied to the regression constants for the equations in tables 6 through 9. Bias-correction factors for the equations in tables 6 through 9 ranged from 1.024 to 1.490 , with an average of 1.138. Bias-correction factors were not used in the peak-flow equations in table 10 because of the small data base.

The generalized least-squares estimator in the GLSNET program (Tasker and Stedinger, 1989) in ANNIE (Lumb and others, 1990) was then used to compute the final regression equations. The final regression equations were checked to ensure that all independent variables were statistically significant, the coefficients of the independent variables were hydrologically reasonable, correlation between independent variables was not significant, the standard error was minimized, the coefficient of determination was maximized, overly influential observations were not present, and that residual variances were constant. 
Table 5. Summary of data for continuous-record gaging stations, partial-record stations, and miscellaneous sites used in regional regression analysis, Tutuila, American Samoa

[7Q2, 7-day, 2-year low flow; 7Q10, 7-day 10-year low flow; $\mathrm{ft}^{3} / \mathrm{s}$, cubic feet per second; DA, drainage area; GA, gage altitude; CL, main channel length; $\mathrm{DD}$, drainage density; BR, basin relief; BS, basin slope; BFI, base-flow index; $\mathrm{mi}^{2}$, square mile; $\mathrm{ft}, \mathrm{feet} ; \mathrm{ft} / \mathrm{mi}$, feet per mile; $\mathrm{ft}^{3} / \mathrm{s} / \mathrm{mi}^{2}$, cubic foot per second per square mile]

\begin{tabular}{|c|c|c|c|c|c|c|c|c|c|c|c|c|}
\hline Station & $\begin{array}{c}7 \mathrm{Q} 2 \\
\left(\mathrm{ft}^{3} / \mathrm{s}\right)\end{array}$ & $\begin{array}{l}7 \mathrm{Q} 10 \\
\left(\mathrm{ft}^{3} / \mathrm{s}\right)\end{array}$ & $\begin{array}{c}\text { Mean } \\
\text { flow } \\
\left(\mathrm{ft}^{3} / \mathrm{s}\right)\end{array}$ & $\begin{array}{l}\text { Me- } \\
\text { dian } \\
\text { flow } \\
\left(\mathrm{ft}^{3} / \mathrm{s}\right)\end{array}$ & $\begin{array}{c}\mathrm{DA} \\
\left(\mathrm{mi}^{2}\right)\end{array}$ & $\begin{array}{l}\text { GA } \\
(\mathrm{ft})\end{array}$ & $\begin{array}{c}\mathrm{CL} \\
\text { (mi) }\end{array}$ & $\begin{array}{c}\mathrm{DD} \\
(1 / \mathrm{mi})\end{array}$ & $\begin{array}{l}\text { BR } \\
\text { (ft) }\end{array}$ & $\begin{array}{c}\mathrm{BS} \\
(\mathrm{ft} / \mathrm{mi})\end{array}$ & $\begin{array}{c}\text { BFI } \\
\left(\mathrm{ft}^{3} / \mathrm{s} /\right. \\
\left.\mathrm{mi}^{2}\right)\end{array}$ & $\begin{array}{c}\text { Re- } \\
\text { gion } \\
\text { (plate } \\
1 \text { ) }\end{array}$ \\
\hline 9000 & 0.01 & $<0.01$ & 0.05 & 0.02 & 0.06 & 180 & 0.46 & 5.83 & 590 & 3,440 & 0.17 & 1 \\
\hline 9010 & 0.08 & 0.04 & 0.35 & 0.18 & 0.09 & 160 & 0.63 & 5.89 & 680 & 4,000 & 1.11 & 1 \\
\hline 9020 & 0.02 & 0.01 & 0.08 & 0.04 & 0.03 & 150 & 0.31 & 7.67 & 410 & 3,140 & 1.00 & 1 \\
\hline 9025 & 0.07 & 0.03 & 0.36 & 0.25 & 0.12 & 40 & 0.73 & 7.25 & 800 & 5,800 & 0.71 & 1 \\
\hline 9030 & 0.02 & $<0.01$ & 0.13 & 0.07 & 0.06 & 120 & 0.43 & 9.50 & 430 & 4,080 & 0.50 & 1 \\
\hline 9040 & 0.01 & $<0.01$ & 0.07 & 0.03 & 0.05 & 140 & 0.24 & 3.60 & 640 & 2,300 & 0.21 & 1 \\
\hline 9050 & 0.03 & 0.01 & 0.29 & 0.11 & 0.09 & 220 & 0.65 & 6.00 & 470 & 2,820 & 0.22 & 1 \\
\hline $9060^{b}$ & 0.02 & $<0.01$ & 0.33 & 0.08 & 0.18 & 190 & 0.59 & 6.67 & 690 & 4,600 & 0.17 & ${ }^{\mathrm{a}} 1$ \\
\hline 9070 & 0.02 & 0.01 & 0.11 & 0.07 & 0.06 & 75 & 0.33 & 2.50 & 510 & 1,280 & 0.36 & 1 \\
\hline 9080 & 0.01 & $<0.01$ & 0.18 & 0.07 & 0.08 & 230 & 0.49 & 6.88 & 550 & 3,780 & 0.13 & 1 \\
\hline 9095 & 0.19 & 0.08 & 0.83 & 0.43 & 0.47 & 20 & 0.80 & 4.96 & 1,080 & 5,360 & 0.36 & 1 \\
\hline 9100 & 0.02 & $<0.01$ & 0.22 & 0.12 & 0.01 & 290 & 0.11 & 4.00 & 350 & 1,400 & 2.15 & 1 \\
\hline 9110 & 0.07 & 0.03 & 0.42 & 0.28 & 0.10 & 70 & 0.46 & 7.80 & 880 & 6,864 & 0.60 & 1 \\
\hline $9120^{b}$ & 0.38 & 0.17 & 3.38 & 1.40 & 0.60 & 30 & 1.17 & 5.02 & 1,460 & 7,330 & 0.70 & 1 \\
\hline 9130 & 0.04 & 0.01 & 0.41 & 0.26 & 0.20 & 100 & 0.64 & 8.30 & 1,270 & 10,500 & 0.29 & 1 \\
\hline 9140 & 0.08 & 0.06 & 0.47 & 0.25 & 0.18 & 200 & 0.87 & 8.28 & 810 & 6,710 & 0.95 & 1 \\
\hline 9160 & 0.04 & 0.01 & 0.34 & 0.14 & 0.14 & 80 & 0.54 & 2.86 & 910 & 2,600 & 0.24 & 1 \\
\hline 9170 & 0.13 & 0.04 & 1.10 & 0.62 & 0.19 & 100 & 0.61 & 3.79 & 1,340 & 5,080 & 1.19 & 1 \\
\hline $9175^{b}$ & 0.20 & 0.07 & 1.50 & 0.65 & 0.23 & 10 & 0.77 & 3.83 & 1,430 & 5,480 & 0.96 & 1 \\
\hline 9180 & $<0.01$ & 0 & 0.22 & 0.02 & 0.02 & 40 & 0.36 & 11.00 & 800 & 8,800 & 0.10 & 1 \\
\hline 9190 & 0.75 & 0.32 & 3.46 & 2.40 & 0.60 & 120 & 1.37 & 4.38 & 1,280 & 5,610 & 1.28 & 2 \\
\hline 9192 & 0.16 & 0.09 & 0.52 & 0.40 & 0.16 & 120 & 0.88 & 4.88 & 1,250 & 6,100 & 1.15 & 2 \\
\hline 9194 & 0.09 & 0.05 & 0.26 & 0.21 & 0.15 & 90 & 0.87 & 2.13 & 1,310 & 2,790 & 0.79 & 2 \\
\hline 9198 & 0.07 & 0.03 & 0.35 & 0.24 & 0.24 & 1,080 & 0.52 & 0.92 & 340 & 310 & 0.40 & 2 \\
\hline 9200 & 0.92 & 0.39 & 4.09 & 2.85 & 0.82 & 130 & 1.70 & 3.56 & 1,270 & 4,520 & 2.26 & 2 \\
\hline $9205^{b}$ & 0.97 & 0.40 & 6.09 & 4.10 & 1.03 & 5 & 2.20 & 3.32 & 1,390 & 4,620 & 1.36 & 2 \\
\hline 9220 & 0.74 & 0.28 & 5.40 & 3.60 & 0.78 & 140 & 1.52 & 4.78 & 1,160 & 5,540 & 1.18 & 2 \\
\hline 9230 & 0.24 & 0.13 & 0.96 & 0.70 & 0.18 & 250 & 0.62 & 6.22 & 1,060 & 6,590 & 1.50 & 2 \\
\hline 9240 & 0.16 & 0.07 & 0.90 & 0.61 & 0.17 & 180 & 0.66 & 6.18 & 1,080 & 6,670 & 1.14 & 2 \\
\hline 9250 & 0.90 & 0.52 & 5.00 & 3.30 & 0.74 & 120 & 1.40 & 4.43 & 1,120 & 4,960 & 1.23 & 2 \\
\hline
\end{tabular}


Table 5. Summary of data for continuous-record gaging stations, partial-record stations, and miscellaneous sites used in regional regression analysis, Tutuila, American Samoa--Continued

[7Q2, 7-day, 2-year low flow; 7Q10, 7-day 10-year low flow; $\mathrm{ft}^{3} / \mathrm{s}$, cubic feet per second; DA, drainage area; GA, gage altitude; CL, main channel length; $\mathrm{DD}$, drainage density; $\mathrm{BR}$, basin relief; $\mathrm{BS}$, basin slope; $\mathrm{BFI}$, base-flow index; $\mathrm{mi}^{2}$, square mile; $\mathrm{ft}$, feet; $\mathrm{ft} / \mathrm{mi}$, feet per mile; $\mathrm{ft}^{3} / \mathrm{s} / \mathrm{mi}^{2}$, cubic foot per second per square mile]

\begin{tabular}{|c|c|c|c|c|c|c|c|c|c|c|c|c|}
\hline Station & $\begin{array}{c}7 \mathrm{Q}^{2} \\
\left(\mathrm{ft}^{3} / \mathrm{s}\right)\end{array}$ & $\begin{array}{l}7 \mathrm{Q} 10 \\
\left(\mathrm{ft}^{3} / \mathrm{s}\right)\end{array}$ & $\begin{array}{c}\text { Mean } \\
\text { flow } \\
\left(\mathrm{ft}^{3} / \mathrm{s}\right)\end{array}$ & $\begin{array}{l}\text { Me- } \\
\text { dian } \\
\text { flow } \\
\left(\mathrm{ft}^{3} / \mathrm{s}\right)\end{array}$ & $\begin{array}{c}\text { DA } \\
\left(\mathrm{mi}^{2}\right)\end{array}$ & $\begin{array}{l}\text { GA } \\
\text { (ft) }\end{array}$ & $\begin{array}{c}\mathrm{CL} \\
(\mathrm{mi})\end{array}$ & $\begin{array}{c}\text { DD } \\
(1 / \mathrm{mi})\end{array}$ & $\begin{array}{l}\text { BR } \\
\text { (ft) }\end{array}$ & $\begin{array}{c}\mathrm{BS} \\
(\mathrm{ft} / \mathrm{mi})\end{array}$ & $\begin{array}{c}\text { BFI } \\
\left(\mathrm{ft}^{3} / \mathrm{s} /\right. \\
\left.\mathrm{mi}^{2}\right)\end{array}$ & $\begin{array}{c}\text { Re- } \\
\text { gion } \\
\text { (plate } \\
1 \text { ) }\end{array}$ \\
\hline 9260 & 0.05 & 0.02 & 0.28 & 0.14 & 0.11 & 300 & 0.61 & 3.82 & 4,80 & 1,830 & 0.73 & 2 \\
\hline 9270 & 0.04 & 0.01 & 0.26 & 0.16 & 0.03 & 110 & 0.32 & 7.67 & 4,60 & 3,530 & 1.33 & 2 \\
\hline 9280 & 0.13 & 0.06 & 0.73 & 0.38 & 0.17 & 45 & 0.82 & 5.88 & 760 & 4,470 & 0.68 & 2 \\
\hline 9290 & 0.17 & 0.08 & 0.73 & 0.41 & 0.15 & 80 & 0.87 & 4.33 & 850 & 3,680 & 1.12 & 2 \\
\hline 9300 & 0.11 & 0.04 & 1.05 & 0.44 & 0.16 & 50 & 0.68 & 5.88 & 1,110 & 6,530 & 0.48 & 2 \\
\hline 9302 & 0.07 & 0.02 & 1.00 & 0.36 & 0.21 & 90 & 0.83 & 3.05 & 950 & 2,900 & 0.14 & 2 \\
\hline $9310^{b}$ & 0.20 & 0.08 & 1.45 & 0.69 & 0.24 & 20 & 1.11 & 4.04 & 960 & 3,880 & 0.92 & 2 \\
\hline $9315^{b}$ & 0.47 & 0.24 & 2.54 & 1.60 & 0.32 & 330 & 1.10 & 5.78 & 770 & 4,450 & 2.06 & 2 \\
\hline 9320 & 0.68 & 0.25 & 2.76 & 1.85 & 0.55 & 150 & 1.39 & 6.05 & 1,030 & 6,230 & 1.90 & 2 \\
\hline 9325 & 0.58 & 0.21 & 5.73 & 2.85 & 0.66 & 20 & 1.77 & 5.62 & 1,160 & 6,520 & 1.07 & 2 \\
\hline 9330 & 0.06 & 0.02 & 0.35 & 0.24 & 0.08 & 300 & 0.50 & 3.50 & 570 & 2,000 & 0.67 & 2 \\
\hline $9335^{b}$ & 0.73 & 0.38 & 4.56 & 2.50 & 0.31 & 370 & 0.86 & 5.13 & 920 & 4,720 & 3.55 & 2 \\
\hline 9340 & 0.88 & 0.38 & 4.55 & 2.61 & 0.69 & 240 & 1.21 & 5.35 & 1,050 & 5,620 & 1.84 & 2 \\
\hline 9350 & 0.17 & 0.06 & 1.20 & 0.79 & 0.29 & 280 & 0.88 & 6.24 & 1,040 & 6,490 & 0.79 & 2 \\
\hline 9355 & 0.01 & $<0.01$ & 0.05 & 0.03 & 0.01 & 200 & 0.40 & 8.00 & 280 & 2,240 & 1.00 & 2 \\
\hline 9360 & 0.11 & 0.05 & 0.47 & 0.33 & 0.15 & 620 & 0.82 & 4.93 & 490 & 2,420 & 0.57 & 2 \\
\hline 9370 & 0.32 & 0.18 & 0.85 & 0.67 & 0.18 & 220 & 1.10 & 5.61 & 1,450 & 8,130 & 1.68 & 1 \\
\hline 9380 & 0.11 & 0.05 & 0.55 & 0.26 & 0.09 & 180 & 0.60 & 5.55 & 1,100 & 6,100 & 1.22 & 1 \\
\hline 9390 & 0.06 & 0.03 & 0.20 & 0.12 & 0.02 & 400 & 0.24 & 8.00 & 880 & 7,040 & 3.00 & 2 \\
\hline 9400 & 0.09 & 0.02 & 0.30 & 0.22 & 0.04 & 360 & 0.33 & 6.50 & 960 & 6,240 & 3.00 & 2 \\
\hline 9410 & 0.10 & 0.05 & 0.29 & 0.23 & 0.08 & 400 & 0.59 & 5.50 & 960 & 5,280 & 2.29 & 2 \\
\hline 9420 & 0.10 & 0.05 & 0.37 & 0.25 & 0.09 & 190 & 0.61 & 5.00 & 1,250 & 6,250 & 1.48 & 1 \\
\hline 9430 & 0.31 & 0.15 & 0.98 & 0.60 & 0.14 & 220 & 0.58 & 2.00 & 1,320 & 2,640 & 3.36 & 1 \\
\hline 9440 & 0.54 & 0.21 & 2.83 & 1.48 & 0.57 & 120 & 0.98 & 4.32 & 1,700 & 7,340 & 1.35 & 1 \\
\hline $9442^{b}$ & 0.18 & 0.04 & 4.18 & 1.30 & 0.78 & 30 & 1.38 & 4.54 & 1,800 & 8,170 & 0.08 & ${ }^{a} 1$ \\
\hline 9450 & 0.11 & 0.04 & 1.30 & 0.45 & 0.19 & 190 & 1.14 & 5.74 & 1,420 & 8,150 & 1.22 & 1 \\
\hline 9460 & 0.10 & 0.05 & 0.40 & 0.23 & 0.09 & 140 & 0.50 & 4.44 & 9,80 & 4,350 & 0.85 & 1 \\
\hline 9470 & 0.03 & 0.01 & 0.58 & 0.17 & 0.22 & 100 & 0.82 & 5.18 & 1,650 & 8,550 & 0.19 & 1 \\
\hline $9480^{b}$ & 0.04 & 0.02 & 1.44 & 0.30 & 0.25 & 80 & 1.18 & 4.40 & 1,530 & 6,730 & 0.36 & ${ }^{\mathrm{a}} 1$ \\
\hline 9490 & 0.14 & 0.09 & 1.10 & 0.33 & 0.24 & 460 & 0.85 & 3.83 & 1,250 & 4,790 & 0.35 & ${ }^{a} 1$ \\
\hline 9495 & 0.13 & 0.08 & 1.10 & 0.32 & 0.42 & 75 & 1.33 & 5.64 & 1,640 & 9,250 & 0.42 & ${ }^{a_{1}}$ \\
\hline
\end{tabular}


Table 5. Summary of data for continuous-record gaging stations, partial-record stations, and miscellaneous sites used in regional regression analysis, Tutuila, American Samoa--Continued

[7Q2, 7-day, 2-year low flow; 7Q10, 7-day 10-year low flow; $\mathrm{ft}^{3} / \mathrm{s}$, cubic feet per second; DA, drainage area; GA, gage altitude; CL, main channel length; $\mathrm{DD}$, drainage density; BR, basin relief; BS, basin slope; BFI, base-flow index; $\mathrm{mi}^{2}$, square mile; $\mathrm{ft}$, feet; $\mathrm{ft} / \mathrm{mi}$, feet per mile; $\mathrm{ft}^{3} / \mathrm{s} / \mathrm{mi}^{2}$, cubic foot per second per square mile]

\begin{tabular}{|c|c|c|c|c|c|c|c|c|c|c|c|c|}
\hline Station & $\begin{array}{c}7 Q^{2} \\
\left(\mathrm{ft}^{3} / \mathrm{s}\right)\end{array}$ & $\begin{array}{l}7 \mathrm{Q} 10 \\
\left(\mathrm{ft}^{3} / \mathrm{s}\right)\end{array}$ & $\begin{array}{c}\text { Mean } \\
\text { flow } \\
\left(\mathrm{ft}^{3} / \mathrm{s}\right)\end{array}$ & $\begin{array}{l}\text { Me- } \\
\text { dian } \\
\text { flow } \\
\left(\mathrm{ft}^{3} / \mathrm{s}\right)\end{array}$ & $\begin{array}{c}\text { DA } \\
\left(\mathrm{mi}^{2}\right)\end{array}$ & $\begin{array}{l}\mathrm{GA} \\
(\mathrm{ft})\end{array}$ & $\begin{array}{l}\mathrm{CL} \\
\text { (mi) }\end{array}$ & $\begin{array}{c}\text { DD } \\
(1 / \mathrm{mi})\end{array}$ & $\begin{array}{l}B R \\
(f t)\end{array}$ & $\begin{array}{c}\mathrm{BS} \\
(\mathrm{ft} / \mathrm{mi})\end{array}$ & $\begin{array}{c}\mathrm{BFI} \\
\left(\mathrm{ft}^{3} / \mathrm{s} /\right. \\
\left.\mathrm{mi}^{2}\right)\end{array}$ & $\begin{array}{c}\mathrm{Re}- \\
\text { gion } \\
\text { (plate } \\
1 \text { ) }\end{array}$ \\
\hline 9497 & 0.06 & 0.02 & 0.35 & 0.16 & 0.05 & 540 & 0.40 & 6.40 & 980 & 6,270 & 1.23 & 1 \\
\hline 9498 & 0.23 & 0.14 & 0.65 & 0.42 & 0.07 & 510 & 0.35 & 4.00 & 1,050 & 4,200 & 3.63 & 1 \\
\hline 9505 & 0.14 & 0.06 & 0.45 & 0.25 & 0.17 & 290 & 0.63 & 3.29 & 1,220 & 4,010 & 0.55 & ${ }^{\mathrm{a}} 1$ \\
\hline 9510 & 0.65 & 0.30 & 6.40 & 1.76 & 0.75 & 50 & 1.21 & 5.91 & 1,460 & 8,630 & 0.44 & ${ }^{\mathrm{a}} 1$ \\
\hline 9525 & 0.09 & 0.03 & 0.44 & 0.21 & 0.14 & 140 & 0.45 & 3.57 & 1,330 & 4,750 & 0.92 & 1 \\
\hline 9530 & 0.07 & 0.03 & 0.24 & 0.14 & 0.03 & 180 & 0.32 & 7.67 & 1,300 & 9,970 & 2.15 & 1 \\
\hline 9550 & 0.04 & 0.02 & 0.37 & 0.15 & 0.05 & 60 & 0.53 & 8.40 & 970 & 8,150 & 1.49 & 1 \\
\hline 9555 & 0.02 & $<0.01$ & 0.16 & 0.06 & 0.06 & 60 & 0.40 & 4.83 & 580 & 2,800 & 0.31 & 1 \\
\hline 9560 & 0.33 & 0.19 & 1.07 & 0.65 & 0.19 & 90 & 0.55 & 3.53 & 1,520 & 5,370 & 1.87 & 1 \\
\hline 9565 & 0.02 & 0.01 & 0.11 & 0.05 & 0.05 & 100 & 0.31 & 4.80 & 800 & 3,840 & 0.37 & 1 \\
\hline 9570 & 0.13 & 0.05 & 0.68 & 0.32 & 0.02 & 80 & 0.24 & 8.50 & 520 & 4,420 & 5.60 & 1 \\
\hline 9580 & 0.04 & 0.01 & 0.63 & 0.20 & 0.10 & 190 & 0.53 & 6.00 & 730 & 4,380 & 0.37 & 1 \\
\hline 9585 & 0.05 & 0.02 & 0.22 & 0.12 & 0.02 & 150 & 0.32 & 10.50 & 650 & 6,825 & 2.44 & 1 \\
\hline 9590 & 0.11 & 0.05 & 0.84 & 0.37 & 0.16 & 35 & 0.65 & 6.25 & 880 & 5,500 & 0.90 & 1 \\
\hline $9600^{b}$ & 0.42 & 0.23 & 1.21 & 0.78 & 0.19 & 180 & 0.94 & 6.00 & 890 & 5,340 & 2.21 & 1 \\
\hline 9605 & 0.15 & 0.08 & 0.40 & 0.26 & 0.04 & 200 & 0.29 & 4.75 & 850 & 4,040 & 6.02 & 1 \\
\hline 9610 & 0.16 & 0.08 & 1.01 & 0.48 & 0.22 & 280 & 0.62 & 5.64 & 830 & 4,680 & 0.76 & 1 \\
\hline 9620 & 0.03 & 0.01 & 0.32 & 0.12 & 0.09 & 100 & 0.45 & 3.78 & 660 & 2,500 & 0.47 & 1 \\
\hline 9630 & 0.02 & $<0.01$ & 0.45 & 0.11 & 0.10 & 120 & 0.56 & 7.20 & 540 & 3,890 & 0.20 & 1 \\
\hline $9639^{b}$ & 0.04 & 0.02 & 0.32 & 0.11 & 0.11 & 120 & 0.60 & 6.54 & 710 & 4,640 & 0.36 & 1 \\
\hline 9640 & 0.05 & 0.02 & 0.24 & 0.12 & 0.12 & 100 & 0.62 & 6.17 & 730 & 4,500 & 0.46 & 1 \\
\hline 9650 & 0.03 & 0.02 & 0.14 & 0.08 & 0.10 & 140 & 0.75 & 7.90 & 930 & 7,350 & 0.42 & 1 \\
\hline 9660 & 0.01 & 0.01 & 0.03 & 0.02 & 0.02 & 110 & 0.24 & 8.00 & 290 & 2,320 & 1.00 & 1 \\
\hline $2^{c}$ & 0.08 & 0.05 & 0.29 & 0.17 & 0.15 & 240 & 0.55 & 6.38 & 640 & 4,080 & 0.56 & 1 \\
\hline $40^{c}$ & 0.70 & 0.26 & 5.80 & 2.70 & 0.50 & 365 & 0.94 & 5.20 & 925 & 4,810 & 1.80 & 2 \\
\hline $43^{c}$ & 0.13 & 0.06 & 0.70 & 0.49 & 0.14 & 400 & 0.82 & 6.29 & 850 & 5,340 & 1.79 & 2 \\
\hline $46^{c}$ & 0.30 & 0.14 & 1.60 & 1.10 & 0.35 & 200 & 1.30 & 5.86 & 900 & 5,270 & 1.60 & 2 \\
\hline
\end{tabular}

\footnotetext{
${ }^{\text {a }}$ Station had significant diversions, not used in regional regression analysis.

${ }^{\mathrm{b}}$ Continuous-record stream-gaging station

${ }^{c}$ Miscellaneous sites treated as low-flow partial-record sites
} 
Table 6. Regression equations for estimating low-flow characteristics for ungaged sites in region 1, eastern Tutuila, American Samoa

[Region 1 shown in plate 1]

\begin{tabular}{rcc}
\hline Regression equation & $\begin{array}{c}\text { Adjusted coefficlent of } \\
\text { determination, } \mathbf{R}^{2}\end{array}$ & $\begin{array}{c}\text { Standard error of } \\
\text { estimate (percent) }\end{array}$ \\
\hline $7 \mathrm{Q} 2=0.0000335(\mathrm{DA})^{0.488}(\mathrm{GA})^{0.244}(\mathrm{BR})^{1.16}$ & 0.47 & 95.2 \\
$7 \mathrm{Q} 10=0.00000447(\mathrm{DA})^{0.448}(\mathrm{GA})^{0.280}(\mathrm{BR})^{1.30}$ & 0.41 & 110 \\
Mean $=0.00188(\mathrm{DA})^{0.474}(\mathrm{BR})^{0.983}$ & 0.59 & 62.6 \\
Median $=0.000619(\mathrm{DA})^{0.478}(\mathrm{BR})^{1.04}$ & 0.56 & 66.5 \\
\hline
\end{tabular}

Applicable range

DA: drainage area, in square miles. . . . . . . .

$\begin{array}{cc}\text { minimum } & \text { maximum } \\ 0.01 & 0.60 \\ 10 & 540 \\ 290 & 1,700\end{array}$

BR: basin relief, in feet. ................. $290 \quad 1,700$

7Q2: 7-day, 2-year low flow

7Q10: 7-day, 10-year low flow

Mean: mean flow

Median: median flow

Table 7. Regression equations for estimating low-flow characteristics for sites with some streamflow measurements in region1, eastern Tutuila, American Samoa

[Region 1 shown in plate 1]

\begin{tabular}{rcc}
\hline Regression equation & $\begin{array}{c}\text { Adjusted coefficlent } \\
\text { of determination, } \mathbf{R}^{2}\end{array}$ & $\begin{array}{c}\text { Standard error of } \\
\text { estimate (percent) }\end{array}$ \\
\hline $7 \mathrm{Q} 2=0.773(\mathrm{DA})^{0.950}(\mathrm{BFI})^{0.920}$ & 0.95 & 20.3 \\
$7 \mathrm{Q} 10=0.369(\mathrm{DA})^{0.982}(\mathrm{BFI})^{1.04}$ & 0.91 & 25.4 \\
Mean $=4.45(\mathrm{DA})^{0.903}(\mathrm{BFI})^{0.518}$ & 0.72 & 43.8 \\
Median $=2.33(\mathrm{DA})^{0.960}(\mathrm{BFI})^{0.700}$ & 0.87 & 21.8 \\
\hline
\end{tabular}

DA: drainage area, in square miles................

\begin{tabular}{|c|c|}
\hline \multicolumn{2}{|c|}{ Applicable range } \\
\hline minimum & maximu \\
\hline 0.01 & 0.60 \\
\hline 0.1 & 6.02 \\
\hline
\end{tabular}

7Q2: 7-day, 2-year low flow

7Q10: 7-day, 10-year low flow

Mean: mean flow

Median: median flow 
Table 8. Regression equations for estimating low-flow characteristics for ungaged sites in region 2, western Tutuila, American Samoa

[Region 2 shown in plate 1]

\begin{tabular}{rcc}
\hline Regression equation & $\begin{array}{c}\text { Adjusted coefficient of } \\
\text { determination, } \mathbf{R}^{2}\end{array}$ & $\begin{array}{c}\text { Standard error of } \\
\text { estimate (percent) }\end{array}$ \\
\hline $7 \mathrm{Q} 2=0.00365(\mathrm{DA})^{0.909}(\mathrm{GA})^{0.110}(\mathrm{BS})^{0.594}$ & 0.90 & 34.2 \\
$7 \mathrm{Q} 10=0.000925(\mathrm{DA})^{0.922}(\mathrm{GA})^{0.135}(\mathrm{BS})^{0.645}$ & 0.86 & 37.5 \\
Mean $=0.0862(\mathrm{DA})^{0.972}(\mathrm{BS})^{0.497}$ & 0.90 & 36.5 \\
Median $=0.0464(\mathrm{DA})^{0.964}(\mathrm{BS})^{0.510}$ & 0.92 & 29.8 \\
\hline
\end{tabular}

Applicable range

DA: drainage area, in square miles. . . . . . . . . . . $0.01 \quad 1.03$

GA: gage altitude, in feet ................. $5 \quad 1,080$

BS: basin slope, in feet per mile............ $310 \quad 7,040$

7Q2: 7-day, 2-year low flow

7Q10: 7-day, 10-year low flow

Mean: mean flow

Median: median flow

Table 9. Regression equations for estimating low-flow characteristics for sites with some streamflow measurements in region 2 , western Tutuila, American Samoa

[Region 2 shown in plate 1]

\begin{tabular}{|c|c|c|}
\hline Regression equation & $\begin{array}{l}\text { Adjusted coefficient of } \\
\text { determination, } R^{2}\end{array}$ & $\begin{array}{l}\text { Standard error of } \\
\text { estimate (percent) }\end{array}$ \\
\hline $7 \mathrm{Q} 2=0.142(\mathrm{DA})^{0.905}(\mathrm{BS})^{0.206}(\mathrm{BFI})^{0.549}$ & 0.97 & 13.7 \\
\hline $7 \mathrm{Q} 10=0.0741(\mathrm{DA})^{0.920}(\mathrm{BS})^{0.181}(\mathrm{BFI})^{0.666}$ & 0.94 & 13.3 \\
\hline Mean $=0.229(\mathrm{DA})^{0.986}(\mathrm{BS})^{0.377}(\mathrm{BFI})^{0.199}$ & 0.91 & 35.2 \\
\hline Median $=0.309(\mathrm{DA})^{0.984}(\mathrm{BS})^{0.276}(\mathrm{BFI})^{0.366}$ & 0.95 & 21.6 \\
\hline
\end{tabular}

Applicable range

minimum maximum

DA: drainage area, in square miles. ............... $0.01 \quad 1.03$

BS: basin slope, in feet per mile. .............. $310 \quad 7,040$

BFI: Base-flow index, in cubic feet per second per square mile $\quad 0.14$

7Q2: 7-day, 2-year low flow

7Q10: 7-day, 10-year low flow

Mean: mean flow

Median: median flow 
Table 10. Regression equations for estimating peak flood flows for streams on Tutuila, American Samoa

\begin{tabular}{ccc}
\hline Regression equation & $\begin{array}{c}\text { Adjusted coefficient of } \\
\text { determination, } \mathbf{R}^{2}\end{array}$ & $\begin{array}{c}\text { Standard error of } \\
\text { estimate (percent) }\end{array}$ \\
\hline $\mathrm{Q}_{2}=1,040\left(\mathrm{DA}^{1.13}\right)$ & 0.66 & 47.4 \\
$\mathrm{Q}_{5}=1,530\left(\mathrm{DA}^{1.10}\right)$ & 0.66 & 45.8 \\
$\mathrm{Q}_{10}=1,810\left(\mathrm{DA}^{1.07}\right)$ & 0.66 & 45.1 \\
$\mathrm{Q}_{25}=2,110\left(\mathrm{DA}^{1.02}\right)$ & 0.64 & 44.4 \\
$\mathrm{Q}_{50}=2,300\left(\mathrm{DA}^{0.981}\right)$ & 0.63 & 44.0 \\
$\mathrm{Q}_{100}=2,470\left(\mathrm{DA}^{0.941}\right)$ & 0.60 & 44.1 \\
\hline
\end{tabular}

$\mathrm{Q}_{\mathrm{t}}=$ estimated peak flood flow in cubic feet per second, where $\mathrm{t}=2-, 5-, 10-, 25-, 50-$, and 100-year recurrence intervals.

DA: drainage area, in square miles. .............. $\frac{\text { minimum }^{\text {Applicable range }}}{0.11} \quad \frac{\text { maximum }}{.078}$

For peak-flow regression analysis, ordinary-leastsquares regression procedures were used to develop the final regression equations. Generalized-least-squares regression procedures were not used because the cross correlations among stations were low (average of 0.31) and the limited number of stations available did not provide a reasonable range and distribution of record lengths to make generalized-least-squares analysis superior to ordinary-least-squares analysis (Stedinger and Tasker, 1985).

Accuracy of low-flow and peak-flow characteristics estimated from the regression equations in tables 6 through 10 is dependent on the standard error of the regression relation and the data used to define the regression equations. The regression equations in tables 6 through 9 apply only to perennial streams where low flows are not significantly affected by diversions. Perennial streams can be identified as solid blue lines on the 1:24,000-scale USGS 1963 topographic map of Tutuila. In this study, any diversion for municipal use was defined as significant. Municipal diversion structures are usually well-maintained and resulting withdrawals are relatively constant. Diversions for domestic uses in the villages have been detected upstream of five continuous gaging stations. These diversions significantly affected low flows at only two of the five stations (9060 and 9480). Effects of diversions at low-flow partialrecord stations and miscellaneous sites generally cannot be detected from the data collected. Most domestic diversions are small, not always well-maintained, and do not withdraw constantly. Therefore, low-flow partialrecord stations and miscellaneous sites with domestic diversions were not excluded from this study. The peak flood-flow regression equations in table 10 apply only to streams not affected by urbanization. The equations are based on data from 10 gaged streams on Tutuila, none of which represent flow from areas of high channelization and pavement. As a result, the available peak-flow data do not represent urbanized conditions.

The standard errors of the regression equations apply only to streamflow estimates for basins that have values of the independent variable(s) (basin characteristics) within the range of those values used to derive that equation. For the equations in tables 6 through 10, applicable ranges of the independent variables are shown in each table. The use of the regression equations with values that fall outside the given ranges can result in large extrapolation errors. Although the regression equations in tables 6 through 10 provide unique numerical answers for low-flow and peak-flood characteristics, the user's judgement is essential to achieving reliable results. Conditions in some drainage basins on Tutuila may be significantly different or unusual compared with those in the basins used to derive the regression equations. For such drainage basins, the user must decide if conditions warrant use or possibly adjustment of the computed values.

Regionalization.--For regional analysis, drainage basins with similar flood response or streamflow char- 
acteristics are grouped into homogeneous regions. Homogeneity of a region's streamflow characteristics can reduce errors in estimates of these streamflow characteristics, whereas heterogeneity can result in higher estimation errors. In this study, regional analysis was done by using the method of residuals. The method of residuals involves classifying basins into regions using the sign and magnitude of the residuals (differences between observed and computed streamflow characteristics), basin and climatic conditions, and hydrologic judgement. Residuals with similar sign and magnitude are assumed to represent regions with similar streamflow characteristics and are grouped together. Because of the subjective nature of this method, Tasker (1982) proposed the use of the Wilcoxon signed-ranks test to provide some objectivity. This non-parametric test is used to compare residuals between regions to determine if the apparent grouping of the residuals represents consistent differences in the residuals. The Wilcoxon signed-ranks test does not statistically verify the regions but provides a quantitative index as a guide for defining "homogeneous" regions (Tasker, 1982). In addition to the Wilcoxon signed-ranks test, the regression equations for all regions were tested to insure that they met the regression requirements stated above. For the Wilcoxon signed-ranks test a significance level of $0.10(10$ percent) was used for regional verification. Failure of the Wilcoxon signed-ranks test indicates that the residuals for the individual regions are not consistently different from those of other regions.

Regression analysis was done using all 81 data sites for the four low-flow characteristics both with and without the base-flow index variable. The significant variables were drainage area, basin relief and gage altitude. The residuals in log units from the 7-day 2-year low-flow and mean-flow regression analyses were then plotted on a map of Tutuila. On the basis of this residual plot, a number of geographically continuous regions were identified. These potential regions were then checked using the Wilcoxon signed-ranks test and by regression analysis. The ideal grouping was determined to be one that divided Tutuila into two regions, eastern and western Tutuila. The dividing line between the regions, which was extended to both coasts, is located near Malaeimi Valley (see plate 1). This dividing line also corresponds to differences in geology on Tutuila. For the Wilcoxon signed-ranks test, the two groupings were significant at the 0.10 (10 percent) significance level. Regression equations were then determined for both the regions and these are given in tables 6 through 9. Regional analysis was not done for the peak-flow regression analysis because of the sparse data set. Basin characteristics required by the equations are also identified in tables 6 through 9 and explained below. Streamflow measurements from 49 miscellaneous sites and low-flow characteristics for 25 out of the 49 sites are listed in table 4 . Locations of the 49 miscellaneous sites are shown in plate 1 .

Results from the regression analysis of peak floods show that drainage area was the only independent variable that was statistically significant. The values of the coefficient of determination in table 10 are low, signifying that drainage area alone does not explain much of the variations in the peak-flood estimates. It should be noted that Aasu Stream, station 9205, was an influential observation causing a bias in the initial peak-flow regression analysis. Aasu stream has the largest gaged drainage area (table 1) and low peak-flow estimates (table 2). This situation may result from the permeable cinders at Aasu Stream's headwaters causing little runoff. The data from Aasu Stream were deleted from further analysis because of their unique nature. The final regression equations in table 10 are based on data from the remaining 10 stations. The potential influence of Aasu Stream on regional flood peaks is illustrated in figure 6 , which shows the regression line for the 100 year flood compared with the maximum observed flood discharges. Figure 6 shows Aasu Stream as clearly having a different flood response than the other 10 gaged basins.

Drainage-basin characteristics.--For regional regression analysis, the drainage-basin characteristics that might be related to low and peak streamflow characteristics need to be described in quantitative form. The following seven basin characteristics were considered in this study for regionalizing the low-flow estimates: drainage area, gage altitude, main channel length, drainage density, basin relief, basin slope, and base-flow index. For the peak-flow regionalization, base-flow index was not used, and two additional basin characteristics, channel slope and basin altitude, were added. These two characteristics are listed for the 11 continuous-record stream-gaging stations in table 2 . The other seven characteristics are listed for the 11 continuous gaging stations and 77 low-flow partial-record stations and miscellaneous sites in table 5 and all nine are described below. 


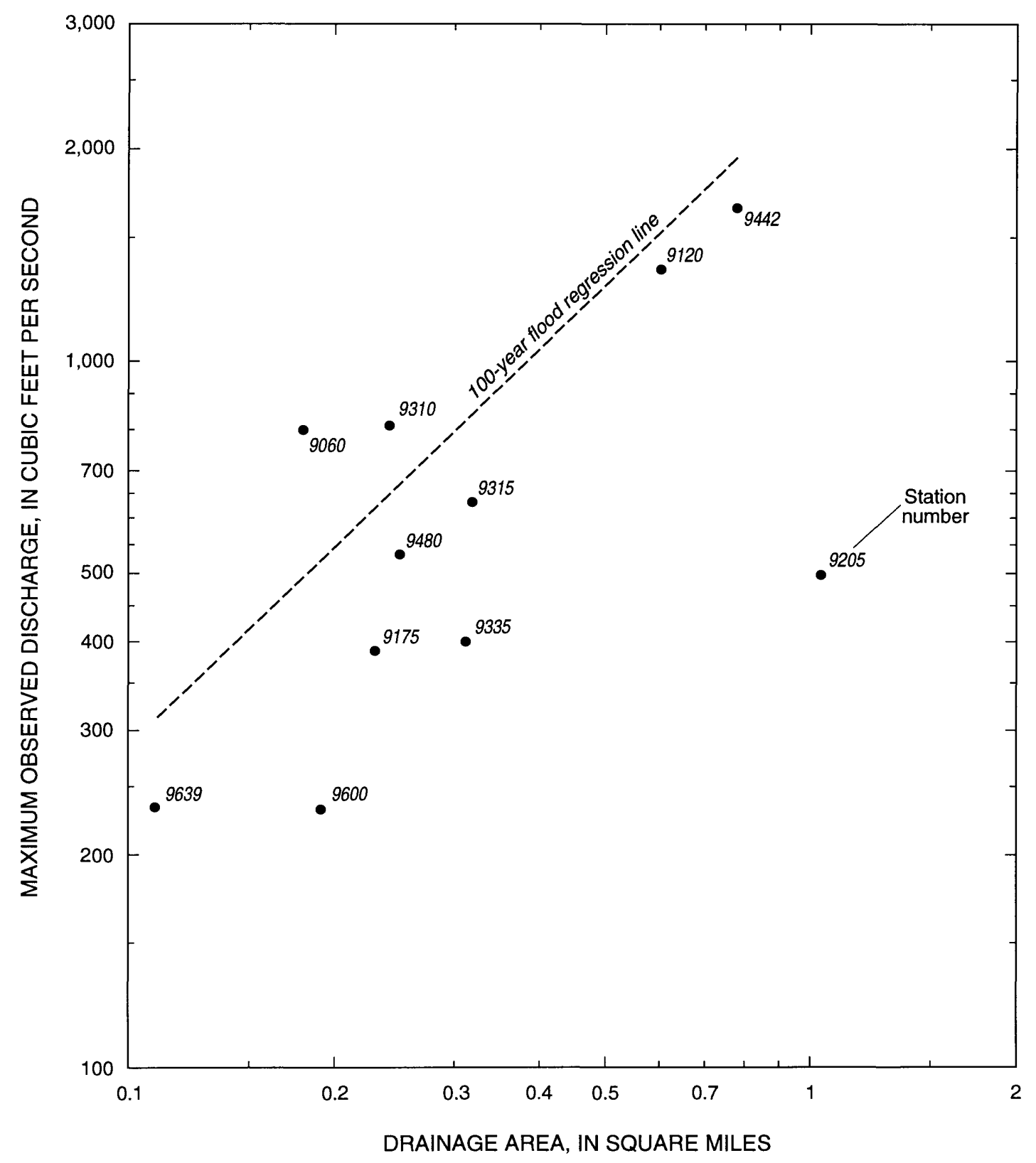

Figure 6. Maximum observed flood discharges compared with drainage area and 100-year flood regression line (with bias-correction factor) for stream-gaging stations on Tutuila, American Samoa. 
Drainage area (DA)--in square miles; measured by planimetering or by computer digitizing using a geographic information systems (GIS) analysis of the area enclosed by basin divides drawn on the 1963 and 1989 1:24,000-scale USGS topographic map of Tutuila. Previous studies have shown that drainage area is an important factor in estimating streamflow characteristics for a basin (Thomas and Benson, 1970). Drainage areas measured using 1963 or 1989 maps should provide equivalent results.

Gage altitude (GA)--in feet; is the stream altitude at the gaged site measured either from the 1963 1:24,000-scale USGS topographic map or by field survey from a known benchmark.

Main channel length (CL)--in miles; is the longest distance measured along a stream from the gaged site to the basin divide. The stream channel was defined by the stream symbol (blue line) on the 1989 1:24,000-scale USGS topographic map and measured by using GIS analysis. Alternatively, channel length can be measured by using a compass or divider set to a $0.02 \mathrm{mi}$ increment.

Drainage density (DD)--in 1/miles; is the ratio of the total length of all stream channels in a basin divided by the drainage area. The total length of stream channels was defined by the blue lines on the 1989 1:24,000scale USGS topographic map and determined by the same methods as channel length.

Basin relief (BR)--in feet; is the measure of the difference between the highest altitude and the gage altitude in a basin (Fennessey and Vogel, 1990). The highest basin altitude was determined from the 1989 1:24,000-scale USGS topographic map by averaging the three highest points in the basin (Fennessey and Vogel, 1990).

Basin slope (BS)--in feet/mile; determined by multiplying the basin relief and drainage density (BS = BR $x$ DD) (Fennessey and Vogel, 1990).

Base-flow index (BFI)--in cubic feet per second per square mile; is an indicator of a stream's low-flow potential. Base-flow measurements provide information about the aquifer characteristics that provide baseflow to a stream. Because measurements are obtained at various flow durations and at sites with different drainage areas, it is necessary to relate them to an index station. This is computed by the following equation:

$$
\mathrm{BFI}=\frac{Q_{m} Q_{90}}{\mathrm{DA} Q_{i}}
$$

where:

$$
\begin{aligned}
\mathrm{BFI}= & \text { base-flow index, in cubic feet per } \\
& \text { second per square mile, } \\
\mathrm{Q}_{\mathrm{m}}= & \text { measured discharge at low-flow } \\
& \text { partial-record station or miscellaneous } \\
& \text { site, in cubic feet per second, } \\
\mathrm{Q}_{90}= & \text { discharge equalled or exceeded } 90 \\
& \text { percent of the time at the index station, } \\
& \text { from flow-duration analysis, in cubic } \\
& \text { feet per second, } \\
\mathrm{DA}= & \text { drainage area of low-flow partial- } \\
& \text { record station or miscellaneous site, in } \\
& \text { square miles, and } \\
\mathrm{Q}_{\mathrm{i}}= & \text { daily mean discharge recorded at } \\
& \text { index station on corresponding day that } \\
& \mathrm{Q}_{\mathrm{m}} \text { was made at the partial-record or } \\
& \text { miscellaneous site, in cubic feet per } \\
& \text { second. }
\end{aligned}
$$

This equation converts the measured discharge $\left(Q_{m}\right)$ to a unit discharge by dividing by drainage area (DA). This value is then adjusted to the 90-percent flow duration by multiplying it by the ratio $\mathrm{Q}_{90} / \mathrm{Q}_{i}$ (Gebert, 1982). The 90-percent flow duration was selected to represent base-flow (Gebert, 1982). For computing base-flow indexes for the low-flow partial-record and miscellaneous sites in this study with multiple measurements, the measurement with the corresponding $Q_{i}$ which is closest to the $\mathrm{Q}_{90}$ at the index station was chosen. This was done to make the ratio $\mathrm{Q}_{90} / \mathrm{Q}_{\mathrm{i}}$ as close to one as possible. For continuous-record stream-gaging stations with computed flow-duration curves, the baseflow index was computed simply as a unit discharge, $\mathrm{Q}_{90} / \mathrm{DA}$. A detailed discussion on calculating and using the base-flow index value at miscellaneous sites with one measurement can be found in the "Discussion of analysis of low-flow characteristics" section.

Channel slope (CS)--in feet per mile; is the main channel slope determined by dividing the elevation difference between points located at the 10 percent and 85 percent distances of the channel length (CL) upstream from the gaged site by the distance between these points (Benson, 1962).

Mean basin altitude (BA)--in feet; determined by placing a uniform grid over the basin outline on a 
1:24,000-scale topographic map. The altitude at a minimum of 20 to 25 grid intersections were determined and the average of these values represents the mean basin altitude.

\section{Discussion of Analysis of Low-Flow Characteristics}

A comparison of all the methods used to estimate low-flow characteristics was conducted by using the computed standard error of estimate, in percent, as a basis for comparison. The standard error of estimate can be computed for all analytical methods used in this study, thus providing a comparison between accuracy and time to collect data. Because error in estimates of streamflow characteristics are dependent on the amount and type of data and the analytical technique used, standard errors are not precise and are presented as a guide to indicate a general level of confidence. Lower standard errors represent lower uncertainty in the estimates of streamflow characteristics. In statistical terms, standard error is the standard deviation of the sampling distribution of a random variable (Freund and Williams, 1991). This means that 67 percent of the estimated streamflow characteristics should lie within one standard error above or below of the true value.

The comparison of accuracy and time to collect data is given in table 11 for region 1 and table 12 for region 2. Such a comparison can help in planning a future data-collection network. From table 11, the average standard error of estimate for the 7-day 2-year low flow at the 5 continuous-record stream-gaging stations in region 1 is 14.4 percent. The average standard error of estimate for the 7-day 2-year low-flow for low-flow partial-record stations and continuous-record gaging stations with less than 9 years of record is 25.2 percent, comparable to that of the miscellaneous sites with a least one base-flow measurement, 20.3 percent. The estimates of the 7-day 2-year low flow at ungaged sites has the highest standard error, but is the easiest to compute in terms of time to collect data.

The comparison of standard errors associated with estimates for 7-day 2-year low-flows for region 2 (table 12 ) is similar to that of table 1. Again, the continuousrecord gaging stations gave the lowest standard errors, and the low-flow partial-record stations and continuous-record gaging stations with less than 9 years of record had comparable standard errors with the miscel- laneous sites. Overall, the stations and sites in region 2 gave 7-day 2-year low-flow estimates with lower standard errors than region 1 . This is probably because of the higher variability of streamflow characteristics in region 1 as a result of the geologic differences.

In both regions, the use of the base-flow index variable provided standard errors for the regression equations that were similar to those at the low-flow partial-record stations (tables 11 and 12). The use of the equations in tables 7 and 9 provides a low-flow estimate with reasonable error considering, the effort involved in data collection. The equations however, should not be thought of as substitutes for low-flow partial-record stations because this comparison looks at just one of the low-flow characteristics and for the low-flow partialrecord sites, the standard error of estimate represents an average. A number of low-flow partial-record stations (table 3) have lower standard errors. Also, in this analysis, the base-flow index variable is assumed to be measured without error.

The base-flow index variable in this study was calculated at most low-flow sites from a selection of numerous measurements and index stations. In practice, it is assumed that only one base-flow measurement will be used. The index station chosen should be the closest to the miscellaneous site in question. When two index stations are close to a miscellaneous site, the base-flow index can be calculated separately using each index station, and then the average of the two values can be used as the base-flow index for that site. This was done for miscellaneous sites 39,41 , and 42 because both index stations, 9205 and 9310, were close to these miscellaneous sites. These index stations were also used with nearby low-flow partial-record stations and miscellaneous sites $(9335,9340,40$, and 43$)$. Having more than one base-flow measurement can improve the reliability of the base-flow index variable by providing increased confidence that a base-flow measurement has been made.

The division between regions 1 and 2 falls near the transition in geology between the older Pago Volcano and the younger Taputapu eruptions (plate 1). The latter eruptions created a layer of permeable cinders on the summit of Taputapu Volcano which reduces surface runoff and sustains higher low flows. This can be briefly illustrated by looking at some flow characteristics at two representative gages, station 9120 for region 1 and station 9205 for region 2 . These gages were chosen to 
Table 11. Methods available to estimate low-flow characteristics in region 1, eastern Tutuila, American Samoa [Region 1 shown in plate 1; 7Q2, 7-day 2-year low flow]

\begin{tabular}{|c|c|c|c|c|c|}
\hline Type of site & Type of data & Number of sites & $\begin{array}{l}\text { Time required } \\
\text { to collect data }\end{array}$ & $\begin{array}{l}\text { Analytical method } \\
\text { to determine } 702\end{array}$ & $\begin{array}{l}\text { Average } \\
\text { standard error } \\
\text { of estimate of } \\
\text { 7Q2 (percent) }\end{array}$ \\
\hline $\begin{array}{l}\text { Continuous stream- } \\
\text { gaging station }\end{array}$ & $\begin{array}{l}9 \text { or more years of re- } \\
\text { corded streamflow } \\
\text { data }\end{array}$ & 5 & 9 to 31 years & frequency analysis & 14.4 \\
\hline $\begin{array}{l}\text { Low-flow partial- } \\
\text { record stations and } \\
\text { continuous gaging } \\
\text { stations with less } \\
\text { than } 9 \text { years of data }\end{array}$ & $\begin{array}{l}8 \text { to } 30 \text { base-flow } \\
\text { measurements }\end{array}$ & 51 & 3 or more years & $\begin{array}{l}\text { moments approach } \\
\text { or graphical correla- } \\
\text { tion }\end{array}$ & $25.2^{\mathrm{b}}$ \\
\hline Miscellaneous sites & $\begin{array}{l}\text { at least } 1 \text { base-flow } \\
\text { measurement }\end{array}$ & $\begin{array}{l}\text { limited to sites } \\
\text { meeting conditions } \\
\text { on page } 21 \text { and table } \\
7\end{array}$ & 1 day & $\begin{array}{l}\text { regression analysis } \\
\text { with data from } 49 \\
\text { sites }\end{array}$ & 20.3 \\
\hline Ungaged sites & basin characteristics & $\begin{array}{l}\text { limited to sites } \\
\text { meeting conditions } \\
\text { on page } 21 \text { and table } \\
6\end{array}$ & 1 hour & $\begin{array}{l}\text { regression analysis } \\
\text { with data from } 49 \\
\text { sites }\end{array}$ & 95.2 \\
\hline
\end{tabular}

${ }^{a}$ includes one miscellaneous site with sufficient measurements

b does not include standard error from station 9180 which has no standard error computed

Table 12. Methods available to estimate low-flow characteristics in region 2, western Tutuila, American Samoa [Region 2 shown in plate 1; 7Q2, 7-day 2-year low flow]

\begin{tabular}{|c|c|c|c|c|c|}
\hline Type of site & Type of data & Number of sites & $\begin{array}{l}\text { Time required } \\
\text { to collect data }\end{array}$ & $\begin{array}{l}\text { Analytical method } \\
\text { to determine 7Q2 }\end{array}$ & $\begin{array}{l}\text { Average } \\
\text { standard error } \\
\text { of estimate of } \\
\text { 7Q2 (percent) }\end{array}$ \\
\hline $\begin{array}{l}\text { Continuous stream- } \\
\text { gaging station }\end{array}$ & $\begin{array}{l}9 \text { or more years of re- } \\
\text { corded streamflow } \\
\text { data }\end{array}$ & 2 & 31 years & frequency analysis & 10.0 \\
\hline Miscellaneous sites & $\begin{array}{l}\text { at least } 1 \text { base-flow } \\
\text { measurement }\end{array}$ & $\begin{array}{l}\text { limited to sites } \\
\text { meeting conditions } \\
\text { on page } 21 \text { and table } \\
9\end{array}$ & 1 day & $\begin{array}{l}\text { regression analysis } \\
\text { with data from } 32 \\
\text { sites }\end{array}$ & 13.7 \\
\hline
\end{tabular}

a includes three miscellaneous sites with sufficient measurements 
represent the two regions based on the number of times they were used as index stations (table 13). From table 13 it can be seen that stations 9120 and 9205 are the most important index stations. Station 9120 has a index of variability from the flow-duration curve of 0.424 , whereas the index of variability is lower (0.335) at station 9205 (table 1). Also from table 1, station 9120 has a larger range between low and peak flows with higher peak flows than station 9205, although the drainage area of station 9120 is smaller. The larger number of different index stations used in region 1 (table 13) is also an indicator of the greater variability of streamflow in region 1.

Table 13. Summary of index stations and the number of partial-record stations which used that index station to estimate low-flow characteristics by region, Tutuila, American Samoa

[Regions shown in plate 1]

\begin{tabular}{cccc}
\hline \multirow{2}{*}{$\begin{array}{c}\text { Index } \\
\text { station }\end{array}$} & \begin{tabular}{c} 
partial-record stations \\
\cline { 2 - 3 }
\end{tabular} & $\begin{array}{c}\text { Number of } \\
\text { Region 1 }\end{array}$ & $\begin{array}{c}\text { Total number } \\
\text { of partial- } \\
\text { record } \\
\text { stations }\end{array}$ \\
\hline 9120 & 20 & 1 & 21 \\
9205 & 14 & 21 & 35 \\
9310 & 3 & 10 & 13 \\
9480 & 10 & 0 & 10 \\
9600 & 10 & 0 & 10 \\
\hline
\end{tabular}

\section{EXAMPLES - HOW TO ESTIMATE STREAMFLOW CHARACTERISTICS}

In order to use the streamflow characteristics or apply the regression equations determined above, the user should have knowledge of the accuracies and limitations involved as explained above in the methods and results section. Applying results from regression equations beyond the limitations of such equations can result in large errors. The following examples illustrate the use of selected regression equations in tables 6 through 10 for estimating streamflow characteristics.

Example 1. Estimate the 7-day 2-year low flow at Mulialevai Stream at Auto. This location is partialrecord station 9610 . For the purposes of this example, assume this is an ungaged site.

For an ungaged site, first determine the region it is in. From plate 1, station 9610 is found to be in region 1. From the 1963 USGS topographic map of Tutuila,
Mulialevai Stream at altitude $280 \mathrm{ft}$ is shown as a perennial stream. To compute the 7-day 2-year low flow at an ungaged site in region 1 use the equation from table 6. For the 7-day 2-year low flow the equation from table 6 is:

$$
7 Q 2=0.0000335(\mathrm{DA})^{0.488}(\mathrm{GA})^{0.244}(\mathrm{BR})^{1.16},
$$

where:

$$
\begin{aligned}
& \text { 7Q2 }=7 \text {-day 2-year low flow, } \\
& \text { DA }=\text { drainage area, in square miles, } \\
& \text { GA }=\text { gage altitude, in feet }, \text { and } \\
& \text { BR }=\text { basin relief, in feet. }
\end{aligned}
$$

Next, determine the necessary basin characteristics. Application of equation 5 requires three basin characteristics. The required basin characteristics are computed from the 1963 or 1989 1:24,000 USGS topographic map of Tutuila. For site 9610 , the computed drainage area is $0.22 \mathrm{mi}^{2}$, gage altitude is $280 \mathrm{ft}$, and basin relief is $830 \mathrm{ft}$ (table 5). These values were computed using methods discussed in the data analysis section of this report.

Next, the computed basin characteristics are checked against the applicable range of basin characteristics in table 6 . The values computed all are within the applicable range, so equation 5 can be used for site 9610. The 7-day 2-year low flow can now be estimated by inserting the computed basin characteristics into equation 5:

$$
\begin{aligned}
7 \mathrm{Q} 2 & =0.0000335(0.22)^{0.488}(280)^{0.244}(830)^{1.16} \\
& =0.0000335(0.478)(3.96)(2430) \\
& =0.15 \mathrm{ft}^{3} / \mathrm{s}
\end{aligned}
$$

The estimate of the 7-day 2-year low flow at station 9610 as an ungaged site is $0.15 \mathrm{ft}^{3} / \mathrm{s}$ and has a standard error of 95.2 percent.

Example 2. Compute the 7-day 2-year low flow assuming station 9610 is a miscellaneous site with one streamflow measurement. The site is in region 1 and because of the streamflow measurement, the equation in table 7 is used. This equation is:

$$
7 Q 2=0.773(D A)^{0.950}(\mathrm{BFI})^{0.920},
$$

where:

7Q2 = 7-day 2-year low flow,

$\mathrm{DA}=$ drainage area, in square miles, and

$\mathrm{BFI}=$ base-flow index, in cubic feet per second per square mile. 
The base-flow index characteristic is described in the regional regression analysis and discussion of analysis of low-flow characteristics sections of this report. The computation of the base-flow index requires the value of the discharge measurement, the corresponding mean daily discharge at a nearby index station, the drainage area of the miscellaneous site, and the flow exceeded 90 percent of the time at the index station. For site 9610 , assume the discharge was $0.16 \mathrm{ft}^{3} / \mathrm{s}$ measured on 9-22-1961. The corresponding mean daily flow at station 9120 , the chosen index station, was 0.40 $\mathrm{ft}^{3} / \mathrm{s}$ (U.S. Geological Survey, 1971). The computed drainage area of station 9610 is $0.22 \mathrm{mi}^{2}$. From table 1 , the flow exceeded 90 percent of the time at 9120 is 0.42 $\mathrm{ft}^{3} / \mathrm{s}$, so the base-flow index computed by applying equation 1 at 9610 is $0.76 \mathrm{ft}^{3} / \mathrm{s} / \mathrm{mi}^{2}$ (table 5).

Inserting the computed basin characteristics into equation 6:

$$
\begin{aligned}
7 \mathrm{Q} 2 & =0.773(0.22)^{0.950}(0.76)^{0.920} \\
& =0.773(0.237)(0.777) \\
& =0.14 \mathrm{ft}^{3} / \mathrm{s} .
\end{aligned}
$$

The 7-day 2-year low flow at station 9610 as a mis-

cellaneous site is $0.14 \mathrm{ft}^{3} / \mathrm{s}$ with a standard error of 20.3 percent. This estimate has a lower standard error of estimate than the value computed in example 1 , so it is likely to be a better estimate of the 7-day 2-year low flow at site 9610 because of the lower uncertainty.

Example 3. Compute the 7-day 2-year low flow at station 9610. In this example, station 9610 is a partialrecord station. The low-flow characteristics have already been computed. From table 3 the 7 -day 2-year low flow is $0.16 \mathrm{ft}^{3} / \mathrm{s}$ with an standard error of 13.4 percent. Because of the lower uncertainty, this estimate is a better one than in example 2. For some sites, the use of equations in tables 7 and 9 at partial-record sites will result in lower standard errors than the graphical correlations or moments method used at that site because of the mathematics involved. If so, the user should decide which estimate to use given the factors involved in the methods used.

Example 4. Compute the 100-year flood at station 9610. Station 9610 is a low-flow partial-record station so use the equations in table 10 . From table 10, the equation for the 100-year flood is:

$$
Q_{100}=2,470(D A)^{0.941},
$$

where:

$$
\begin{aligned}
\mathrm{Q} 100= & \text { the } 100 \text {-year flood, in cubic feet per } \\
& \text { second, and } \\
\mathrm{DA}= & \text { drainage area, in square miles. }
\end{aligned}
$$

The drainage area at station 9610 is $0.22 \mathrm{mi}^{2}$, which falls within the applicable ranges of 0.11 to 0.78 for using equation 7 . Inserting this value into equation 7 yields a 100 -year flood estimate of $594 \mathrm{ft}^{3} / \mathrm{s}$ with a standard error of 44.1 percent. The magnitude of the 100year flood has a 1 in 100 chance of being exceeded in any given year.

\section{SUMMARY}

Techniques for estimating streamflow characteristics for the low, high, and peak flows for streams on Tutuila, American Samoa are discussed in this report.

Application of these techniques allow the user to compute estimates for the 7-day low flow with 2-year and 10-year recurrence intervals; the median flow; the mean flow; and the 2-, 5-, 10-, 25-, 50, and 100-year peak flood flows at sites on gaged and ungaged streams. In addition, frequency techniques were used to compute the 1-, 7-, 14-, 30-, 60-, 90-, 120-, and 183-day low flows with 2-, 5-, 10-, and 20-year recurrence intervals; the 1-, 7-, 15-, 30-day high flows with 2-, 5-, 10-, and 25-year recurrence intervals; and the 2-, 5-, 10-, 25-, $50-, 100$-year peak flows for gaged sites. The equations and streamflow characteristics are based on streamflow data collected from 1958 through 1990 at 11 continuous-record stream-gaging stations with 9 to 32 years of record, 75 low-flow partial-record stations, and 49 miscellaneous sites.

Graphical regression and the moments approach techniques were used to transfer streamflow characteristics from gaged sites to low-flow partial-record sites having eight or more base-flow measurements. Regional regression analysis was used to transfer streamflow characteristics at gaged and low-flow partial-record sites to ungaged and miscellaneous sites. The generalized least squares estimator was used for low-flow regression analysis because it could accommodate the data at low-flow partial-record sites. Regression equations for ungaged sites had standard errors of estimate ranging from 29.8 to 110 percent. Regression analysis 
for miscellaneous sites using the base-flow index basin characteristic provided results with standard errors of estimate ranging from 13.3 to 43.8 percent. These standard errors are comparable to the average values at the low-flow partial-record stations. Regional analysis using the method of residuals, divided Tutuila into two hydrologic regions that correspond to differences in geology and hydrologic response.

Regression analysis of peak-flow data used the ordinary least squares estimator because of the small sample size and low cross-correlations among the gaging stations. The small sample size also prevented the subdivision of Tutuila into more than one region. Peakflow regression equations had coefficients of determination ranging from 0.60 to 0.66 and standard errors of estimate ranging from 44.0 to 47.4 percent. The large standard errors associated with the regression equations result from the large variability of flood peaks compared with drainage area and the small sample size available to analyze this variability. The geology of Tutuila also affects the magnitude of observed flood peaks as seen in the unusual hydrologic conditions of Aasu Stream.

Example applications of the equations for estimating low- and peak-flow characteristics are included. A discussion on the limitations and accuracy of the estimating equations provides guidance to the user. In general, the low-flow regression equations are only applicable for perennial streams with no significant diversions. The peak-flow regression equations are applicable only to non-urbanized drainage basins.

\section{REFERENCES CITED}

Austin, Smith, and Associates, Consulting Engineers, Inc., 1963, Report covering a master-planned water supply and distribution system for the Pago Pago and Tafuna areas: A report to the Government of American Samoa, $48 \mathrm{p}$.

Beard, L.R., 1962, Statistical methods in hydrology: U.S. Army Corps of Engineers, 62 p., app 1-2.

Benson, M.A., 1962, Factors affecting the occurrence of floods in a humid region of diverse terrain: U.S. Geological Survey Water-Supply Paper 1580-B, 64 p.

Department of the Army, Pacific Ocean Division, [U.S. Army] Corps of Engineers, 1976a, Flood hazard study: Fagaalu Stream, Tutuila, American Samoa: 6 p., 4 pls.

-.---, 1976b, Flood hazard study: Leone Village area, Tutuila American Samoa: 6 p., 16 pls. 1977a, Flood hazard study: Aua and Lauliituai, Tutuila American Samoa: 5 p., 14 pls.

------, 1977b, Flood hazard study: Fagaitua and Amouli, Tutuila American Samoa: 5 p., 21 pls.

-.---, 1977c, Flood hazard study: Tafunafou, Tutuila American Samoa: 5 p., 31 pls.

Draper, N.R., and Smith, Harry, 1981, Applied regression analysis (2nd ed.): New York, Wiley, 709 p.

Duan, Naihua, 1983, Smearing estimate: A nonparametric retransformation method: Journal of the American Statistical Association, v. 78, no. 383, p. 605-610.

Fennessey, Neil and Vogel, R.M., 1990, Regional flow-duration curves for ungaged sites in Massachusetts: Journal of Water Resources Planning and Management, v.116, no. 4 , p. $530-549$.

Freund, J.E., and Williams, F.J., 1991, Dictionary/outline of basic statistics: New York, Dover, $195 \mathrm{p}$.

Friel, E.A., Embree, W.N., Jack, A.R., and Atkins, J.T., Jr., 1989, Low-flow characteristics of streams in West Virginia: U.S. Geological Survey Water-Resources Investigations Report 88-4072, 34 p.

Gebert, W.A., 1982, Low-flow characteristics of streams in the central Wisconsin River basin, Wisconsin: U.S. Geological Survey Water-Resources Investigations Report 81-495, 99 p.

Government of American Samoa, 1975, Water system study: western portion of Tutuila island, $85 \mathrm{p}$.

Hardison, C.H., 1969, Accuracy of streamflow characteristics: U.S. Geological Survey Professional Paper 650-D, p. D210-D214.

-------, 1971, Prediction error of regression estimates of streamflow characteristics at ungaged streams: U.S. Geological Survey Professional Paper 750-C, p. C228C236.

----------, 1974, Generalized skew coefficients of annual floods in the United States and their application: Water Resources Research, v. 10, no. 4, p. 745-752.

Hardison, C.H., and Moss, M.E., 1972, Accuracy of low-flow characteristics estimated by correlation of base-flow measurements: U.S. Geological Survey Water-Supply Paper 1542-B, $55 \mathrm{p}$.

Hazen, Allen, 1930, Flood flows: a study of frequencies and magnitudes: New York, Wiley, $199 \mathrm{p}$.

[U.S.] Interagency Advisory Committee on Water Data, 1982, Guidelines for determining flood flow frequency: Hydrology Subcommittee Bulletin 17B, U.S. Department of the Interior, Geological Survey, Reston, Virginia, 28 p., app 1-14.

Kendall, M.G., and Stuart, Alan, 1963, The advanced theory of statistics, volume 1, distribution theory (2nd ed.): New York, Hafner Press, 433 p. 
Kirby, W.H., 1979, Annual flood frequency analysis using U.S. Water Resources Council Guidelines (Program J407), in WATSTORE National Water Data Storage and Retrieval Systems's User's Guide, v. 4, chap. I, section C: U.S. Geological Survey Open-File Report 79-1336-I.

Kite, G.W., 1977, Frequency and risk analysis in hydrology: Fort Collins, Colo., Water Resources Publications, $224 \mathrm{p}$.

Lumb, A.M., Kittle, J.L., and Flynn, K.M., 1990, Users manual for ANNIE, A computer program for interactive hydrologic analyses and data management: U.S.

Geological Survey Water-Resources Investigations Report 89-4080, $236 \mathrm{p}$.

M \& E Pacific, Inc., 1987, Examination of village water systems, American Samoa: prepared for the Environmental Quality Commission, Office of the Governor, American Samoa, p. I-1-XII-17.

Matsuoka, Iwao, 1978, Flow characteristics of streams in Tutuila, American Samoa: U.S. Geological Survey WaterResources Investigations Report 78-103, 34 p.

Meeks, W.C., 1975, Daily values statistics (Program A969), in, WATSTORE National Water Data Storage and Retrieval Systems's User's Guide, v. 1, chap. IV, section G: U.S. Geological Survey Open-File Report 75-426.

Miller, D.M., 1984, Reducing transformation bias in curve fitting: American Statistician, v. 38, no. 2, p. 124-126.

Nakahara, R.H., Yee, J.J.S., Yamashiro, Isao, Tateishi, G.A., and Domingo, J.A., 1990, Water resources data, Hawaii and other Pacific areas, water year 1988, v. 2, Guam, Northern Mariana Islands, Federated States of Micronesia, Palau, and American Samoa, U.S. Geological Survey Water-Data Report HI-88-2, $136 \mathrm{p}$.

National Oceanic and Atmospheric Administration, 19571988, Climatological data annual summary: v. 53-84, no. 13.

Riggs, H.C., 1968a, Some statistical tools in hydrology: U.S. Geological Survey Techniques of Water-Resources Investigations, book 4, chap. A1, 39 p.

--------, 1968b, Frequency curves: U.S. Geological Survey Techniques of Water-Resources Investigations, book 4, chap. A2, $15 \mathrm{p}$.

-..-.-, 1972, Low-flow investigations: U.S. Geological Survey Techniques of Water-Resources Investigations, book 4, chap. B1, $18 \mathrm{p}$.

-.----., 1973, Regional analyses of streamflow characteristics: U.S. Geological Survey Techniques of Water-Resources Investigations, book 4, chap. B3, 15 p.

--------, 1985, Streamflow characteristics: New York, Elsevier, $249 \mathrm{p}$.

Searcy, J.K., 1959, Flow-duration curves: U.S. Geological Survey Water-Supply Paper 1542-A, 33 p.

-.------, 1960, Graphical correlation of gaging-station records: U.S. Geological Survey Water-Supply Paper 1541-C, 34 p.
Stearns, H.T., 1944, Geology of the Samoan Islands: Geological Society of America Bulletin, v. 55, p. 1279-1332.

Stedinger, J.R., and Tasker, G.D., 1985, Regional hydrologic analysis 1: ordinary, weighted, and generalized least squares compared: Water Resources Research, v. 21, no. 9, p. 1421-1432.

Stedinger, J.R., and Thomas, W.O., Jr., 1985, Low-flow frequency estimation using base-flow measurements: U.S. Geological Survey Open-File Report 85-95, 22 p.

Tasker, G.D., 1982, Simplified testing of hydrologic regression regions: Journal of the Hydraulics Division, American Society of Civil Engineers, v. 108, no. HY10, p. 1218-1221.

Tasker, G.D., and Stedinger, J.R., 1986, Regional skew with weighted least squares regression: Journal of Water resources Planning and Management, v. 112, no. 2, p. 225 237.

-._.-.-, 1989, An operational GLS model for hydrologic regression: Journal of Hydrology, v. 111, p. 361-375.

Thomas, D.M., and Benson, M.A., 1970, Generalization of streamflow characteristics from drainage-basin characteristics: U.S. Geological Survey Water-Supply Paper $1975,55 \mathrm{p}$.

U.S. Army [Corps of Engineers] Engineer District, Honolulu, 1977, American Samoa water resources study: plan of study, 80 p., 5 app.

U.S. Army [Corps of Engineers] Engineer District, Honolulu, 1978a, American Samoa water resources study: assessment of water systems American Samoa, 159 p., 3 app.

U.S. Army [Corps of Engineers] Engineer District, Honolulu, 1978b, Hydrologic investigation of surface water for water supply and hydropower, Tutuila island, American Samoa, $55 \mathrm{p}$.

U.S. Department of Commerce, Bureau of Census, 1992, 1990 Census of population and housing; social, economic and housing characteristics, American Samoa: Washington D.C.

U.S. Geological Survey, 1962, Surface water supply of Mariana, Caroline and Samoa Islands through June 1960, U.S. Geological Survey Water-Supply Paper 1751, 107 p.

--, 1971, Surface water supply of the United States 1960-65, part 16, Hawaii and other Pacific Areas, U.S. Geological Survey Water-Supply Paper 1937, 710 p. 1977, Surface water supply of the United States 1966-70, part 16, Hawaii and other Pacific Areas, U.S. Geological Survey Water-Supply Paper 2137, $750 \mathrm{p}$. 
Table 1. Low-flow and high-flow characteristics for continuous-record stream-gaging stations on Tutuila, American Samoa

\section{Vaitolu Stream near Aoa.}

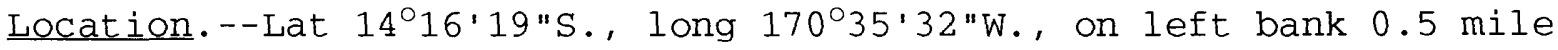
upstream from mouth and $0.7 \mathrm{mile}$ southwest of Aoa.

Drainage area.--0.18 $\mathrm{mi}^{2} \quad$ Tributary to.--Pacific Ocean.

Type of site.--Continuous-record station.

Period of record.--March 1958 - December 1971

Mean discharge (since upstream diversion began).--7 years (1965-71), 0.33 $\mathrm{ft}^{3} / \mathrm{s}$.

Extremes for period of record.--Maximum discharge, $804 \mathrm{ft}^{3} / \mathrm{s}$ on Dec. 19, 1962; minimum, no flow at times in 1964-66.

Low-flow frequency.--As a partial-record station.

\begin{tabular}{lcc}
\hline Streamflow & $\begin{array}{c}\text { Discharge } \\
\mathrm{ft}^{3} / \mathrm{s}\end{array}$ & $\begin{array}{c}\text { Accuracy } \\
\text { \%SE }\end{array}$ \\
\hline 7-day, 2-year low & 0.02 & 27.7 \\
7-day, 10-year low & $<0.01$ & 36.1 \\
Mean (1965-71) & 0.33 & 9.7 \\
Median (1965-71) & 0.08 & 23.1 \\
\hline
\end{tabular}

Basis of estimate.--Moments approach using 56 mean daily base-flow discharges from 1964-71 with station 16912000.

\begin{tabular}{|c|c|c|c|c|c|}
\hline $\begin{array}{l}\text { Dischars } \\
\text { was exce }\end{array}$ & $\begin{array}{l}\text { ratior } \\
\text { for wo } \\
\text { in } \\
\text { ded fo }\end{array}$ & $\begin{array}{l}\text { table } \\
\text { er yea } \\
\text { bic fe } \\
\text { indic }\end{array}$ & $\begin{array}{l}\text { dails } \\
1959 \\
\text { per } \\
\text { d pe }\end{array}$ & $\begin{array}{l}\text { flow } \\
4 \\
\text { cond, } \\
\text { entage }\end{array}$ & $\begin{array}{l}\text { hich } \\
\text { of time }\end{array}$ \\
\hline Percent & 2 & 5 & 10 & 20 & 30 \\
\hline $\mathrm{Et} \mathrm{t}^{3}<\mathrm{s}$ & 3.5 & 1.6 & 1.1 & 0.52 & 0.35 \\
\hline Percent & 40 & 50 & 60 & 70 & 80 \\
\hline $\mathrm{Et}^{3} / \mathrm{s}$ & 0.29 & 0.24 & 0.20 & 0.16 & 0.14 \\
\hline Percent & 90 & 95 & 98 & 99 & 99.9 \\
\hline $\mathrm{ft} \mathrm{t}^{3} / \mathrm{s}$ & 0.09 & 0.08 & 0.06 & 0.05 & 0.03 \\
\hline
\end{tabular}


Table 1. Low-flow and high-flow characteristics for continuous-record stream-gaging stations on Tutuila, American Samoa--Continued

$$
16906000 \text { Vaitolu stream near Aoa--Continued. }
$$

\begin{tabular}{|c|c|c|c|c|c|}
\hline \multicolumn{6}{|c|}{$\begin{array}{l}\text { Duration table of daily flow } \\
\text { for water years } 1965-71 \\
\text { Discharge, in cubic feet per second, which } \\
\text { was exceeded for indicated percentage of tim }\end{array}$} \\
\hline Percent & 2 & 5 & 10 & 20 & 30 \\
\hline $\mathrm{ft} \mathrm{t}^{3} / \mathrm{s}$ & 2.5 & 1.5 & 0.72 & 0.36 & 0.21 \\
\hline Percent & 40 & 50 & 60 & 70 & 80 \\
\hline $\mathrm{ft}^{3} / \mathrm{s}$ & 0.12 & 0.08 & 0.06 & 0.05 & 0.04 \\
\hline Percent & 90 & 95 & 98 & 99 & 99.9 \\
\hline$f t^{3} / s$ & 0.03 & 0.02 & 0.01 & 0 & -- \\
\hline
\end{tabular}

Index of variability $=0.518$

\begin{tabular}{|c|c|c|c|}
\hline $\begin{array}{l}\text { Period } \\
\text { of con- } \\
\text { secutive } \\
\text { days }\end{array}$ & \multicolumn{3}{|c|}{$\begin{array}{l}\text { Magnitude and frequency of annual high } \\
\text { flow for water years } 1959-71 \\
\text { Discharge, in cubic feet per second, for } \\
\text { indicated recurrence interval, in years }\end{array}$} \\
\hline & 2 & 10 & 25 \\
\hline 1 & 8.8 & 14 & 18 \\
\hline 7 & 3.2 & 4.8 & 5.6 \\
\hline 15 & 2.0 & 3.0 & 3.5 \\
\hline 30 & 1.3 & 2.1 & 2.4 \\
\hline
\end{tabular}

Remarks.--Small diversion above station for domestic use since sept 14 , 1964. Because of diversion, low-flow data not suitable for low-flow frequency analysis. Station treated as a partial record site for lowflow frequency. 
Table 1. Low-flow and high-flow characteristics for continuous-record stream-gaging stations on Tutuila, American Samoa--Continued

\section{Pago Stream at Afono.}

Location.--Lat $14^{\circ} 16^{\prime} 03^{\prime \prime S ., ~ l o n g ~} 170^{\circ} 39^{\prime} 02^{\prime \prime W}$, , on left bank 0.2 mile south of Afono and 0.3 mile upstream from mouth.

Drainage area. $--0.60 \mathrm{mi}^{2} \quad$ Tributary to.--Pacific Ocean.

Type of site.--Continuous-record station.

Period of record.--October 1958 - Present as of 1990

Mean discharge. --31 years (water years 1960-90), $3.38 \mathrm{ft}^{3} / \mathrm{s}$.

Extremes for period of record.--Maximum discharge, 1,350 $\mathrm{ft}^{3} / \mathrm{s}$ on July 5, 1969, minimum, $0.10 \mathrm{ft}^{2} / \mathrm{s}$ on September $29,1989$.

\begin{tabular}{lcc}
\hline $\begin{array}{l}\text { Streamflow } \\
\text { characteristic }\end{array}$ & $\begin{array}{c}\text { Discharge } \\
\mathrm{ft}^{3} / \mathrm{S}\end{array}$ & $\begin{array}{c}\text { Accuracy } \\
\% \text { SE }\end{array}$ \\
\hline 7-day, 2-year low & 0.38 & 10.8 \\
7-day, 10-year low & 0.17 & 15.9 \\
Mean & 3.38 & 5.1 \\
Median & 1.40 & 8.4 \\
\hline
\end{tabular}

\begin{tabular}{|c|c|c|c|c|}
\hline $\begin{array}{l}\text { Period } \\
\text { of con- } \\
\text { secutive } \\
\text { days }\end{array}$ & \multicolumn{4}{|c|}{$\begin{array}{l}\text { Magnitude and frequency of annual low } \\
\text { flow for climatic years } 1960-90 \\
\text { Discharge, in cubic feet per second, for } \\
\text { indicated recurrence interval, in years }\end{array}$} \\
\hline & 2 & 5 & 10 & 20 \\
\hline 1 & 0.34 & 0.20 & 0.16 & 0.12 \\
\hline 7 & 0.38 & 0.22 & 0.17 & 0.13 \\
\hline 14 & 0.42 & 0.25 & 0.18 & 0.15 \\
\hline 30 & 0.54 & 0.31 & 0.22 & 0.17 \\
\hline 60 & 0.88 & 0.43 & 0.30 & 0.21 \\
\hline 90 & 1.0 & 0.57 & 0.38 & 0.27 \\
\hline 120 & 1.3 & 0.72 & 0.51 & 0.36 \\
\hline 183 & 1.9 & 1.1 & 0.79 & 0.65 \\
\hline
\end{tabular}


Table 1. Low-flow and high-flow characteristics for continuous-record stream-gaging stations on Tutuila, American Samoa--Continued

$$
16912000 \text { Pago Stream at Afono--continued. }
$$

\begin{tabular}{|c|c|c|c|c|c|}
\hline \multicolumn{6}{|c|}{$\begin{array}{l}\text { Duration table of daily flow } \\
\text { for water years } 1960-1990 \\
\text { Discharge, in cubic feet per second, which } \\
\text { was exceeded for indicated percentage of time }\end{array}$} \\
\hline Percent & 2 & 5 & 10 & 20 & 30 \\
\hline $\mathrm{ft} \mathrm{t}^{3} / \mathrm{s}$ & 26 & 13 & 6.8 & 3.6 & 2.5 \\
\hline Percent & 40 & 50 & 60 & 70 & 80 \\
\hline $\mathrm{et} \frac{3}{} / \mathrm{s}$ & 1.8 & 1.4 & 1.1 & 0.86 & 0.64 \\
\hline Percent & 90 & 95 & 98 & 99 & 99.9 \\
\hline$f t^{3} / s$ & 0.42 & 0.29 & 0.19 & 0.16 & 0.12 \\
\hline
\end{tabular}

Index of variability $=0.424$

\begin{tabular}{ll}
\hline Period & Magnitude and frequency of annual high \\
of con- & flow for water years $1960-90$ \\
secutive & Discharge, in cubic feet per second, for \\
days & indicated recurrence interval, in years \\
\hline
\end{tabular}

\begin{tabular}{rrrrr} 
& 2 & 5 & 10 & 25 \\
\cline { 2 - 5 } 1 & 72 & 102 & 119 & 141 \\
7 & 25 & 34 & 38 & 43 \\
15 & 15 & 20 & 22 & 25 \\
30 & 10 & 13 & 15 & 16 \\
\hline
\end{tabular}

Remarks. --About $0.06 \mathrm{ft}^{3} / \mathrm{s}$ is diverted about $0.5 \mathrm{mile}$ above station for domestic use in Afono since 1958. 
Table 1. Low-flow and high-flow characteristics for continuous-record stream-gaging stations on Tutuila, American Samoa--Continued

$$
16917500 \text { Leele Stream at Mouth, at Fagasa. }
$$

Location.--Lat $14^{\circ} 17^{\prime} 28^{\prime \prime S} .$, long $170^{\circ} 43^{\prime} 09^{\prime \prime W}$, , on left bank at Fagasa and 200 ft upstream from mouth.

Drainage area. $--0.23 \mathrm{mi}^{2} \quad$ Tributary to.--Pacific Ocean.

Type of site.--Continuous- and partial-record station.

Period of record.--July 1966 - September 1976 as a continous station, 1977, 1981-90 as a partial-record station.

Mean discharge.--10 years (water years 1967-1976), $1.50 \mathrm{ft}^{3} / \mathrm{s}$.

Extremes for period of record.--Maximum discharge, $390 \mathrm{ft}^{3} / \mathrm{s}$ on Aug. 30, 1970 ; minimum, $0.03 \mathrm{ft}^{3} / \mathrm{s}$ on sept. 3 and $4,1974$.

\begin{tabular}{lcc}
\hline $\begin{array}{l}\text { Streamflow } \\
\text { characteristic }\end{array}$ & $\begin{array}{c}\text { Discharge } \\
\mathrm{ft} / \mathrm{s}\end{array}$ & $\begin{array}{c}\text { Accuracy } \\
\text { oSE }\end{array}$ \\
\hline 7-day, 2-year low & 0.20 & 18.8 \\
7-day, 10-year low & 0.07 & 54.7 \\
Mean & 1.50 & 7.1 \\
Median & 0.65 & 11.1 \\
\hline
\end{tabular}

\begin{tabular}{|c|c|c|c|c|}
\hline $\begin{array}{l}\text { Period } \\
\text { of con- } \\
\text { secutive } \\
\text { days }\end{array}$ & \multicolumn{4}{|c|}{$\begin{array}{l}\text { Magnitude and frequency of annual low } \\
\text { flow for climatic years } 1968-76 \\
\text { Discharge, in cubic feet per second, for } \\
\text { indicated recurrence interval, in years }\end{array}$} \\
\hline & 2 & 5 & 10 & 20 \\
\hline 1 & 0.18 & 0.10 & 0.06 & 0.04 \\
\hline 7 & 0.20 & 0.11 & 0.07 & 0.04 \\
\hline 14 & 0.25 & 0.14 & 0.09 & 0.06 \\
\hline 30 & 0.32 & 0.16 & 0.10 & 0.06 \\
\hline 60 & 0.50 & 0.21 & 0.12 & 0.07 \\
\hline 90 & 0.60 & 0.25 & 0.15 & 0.09 \\
\hline 120 & 0.72 & 0.30 & 0.17 & 0.10 \\
\hline 183 & 1.2 & 0.46 & 0.29 & 0.21 \\
\hline
\end{tabular}


Table 1. Low-flow and high-flow characteristics for continuous-record stream-gaging stations on Tutuila, American Samoa--Continued

16917500 Leele stream at Mouth, at Fagasa--continued.

Duration table of daily flow

for water years 1967-1976

Discharge, in cubic feet per second, which

was exceeded for indicated percentage of time

\begin{tabular}{crrrrr}
\hline Percent & 2 & 5 & 10 & 20 & 30 \\
$\mathrm{ft} \mathrm{3}^{3} / \mathrm{s}$ & 10 & 6.0 & 3.5 & 1.8 & 1.2 \\
\hline Percent & 40 & 50 & 60 & 70 & 80 \\
$\mathrm{ft} \mathrm{3}^{3} / \mathrm{s}$ & 0.83 & 0.65 & 0.52 & 0.40 & 0.31 \\
\hline Percent & 90 & 95 & 98 & 99 & 99.9 \\
$\mathrm{ft}$ & & & & & \\
\hline
\end{tabular}

Index of variability $=0.418$

\begin{tabular}{lc}
\hline Period & Magnitude and frequency of annual high \\
of con- & flow for water years $1967-76$ \\
secutive & Discharge, in cubic feet per second, for \\
days & indicated recurrence interval, in years \\
\hline
\end{tabular}

\begin{tabular}{rrrrr} 
& 2 & 5 & 10 & 25 \\
\cline { 2 - 5 } 1 & 26 & 39 & 47 & 57 \\
7 & 9.0 & 11 & 13 & 15 \\
15 & 5.6 & 7.3 & 7.9 & 8.6 \\
30 & 4.0 & 4.6 & 4.8 & 5.1 \\
\hline
\end{tabular}

Remarks. - No diversion above station. Low-flow frequency analysis based on 9 climatic years of data. List of measurements made, total of 23, during period of operation as a low-flow partial-record station.

\begin{tabular}{cccc} 
Date & Discharge $\left(\mathrm{ft}^{3} / \mathrm{s}\right)$ & Date & Discharge $\left(\mathrm{ft}^{3} / \mathrm{s}\right)$ \\
\cline { 1 - 2 } $11-18-76$ & $\mathrm{c} 0.29$ & $09-14-83$ & 0.06 \\
$11-27-76$ & $\mathrm{c} 0.20$ & $08-17-84$ & 0.08 \\
$12-02-76$ & $\mathrm{c} 1.0$ & $08-07-85$ & 0.41 \\
$12-06-76$ & $\mathrm{ca} 16.0$ & $09-06-85$ & 0.31 \\
$12-28-76$ & $\mathrm{ca} .1$ & $09-04-86$ & 0.41 \\
$01-13-77$ & $\mathrm{~b} 0.24$ & $07-01-87$ & 0.14 \\
$02-01-77$ & 0.92 & $09-04-87$ & 0.26 \\
$08-06-81$ & 0.41 & $09-27-88$ & 0.24 \\
$09-29-81$ & 0.29 & $07-19-89$ & 0.21 \\
$04-28-82$ & 0.27 & $09-27-89$ & 0.14 \\
$10-20-82$ & 0.30 & $07-19-90$ & 0.17 \\
$08-03-83$ & 0.07 & &
\end{tabular}
a, includes surface runoff
b, revision
c, not previously published 
Table 1. Low-flow and high-flow characteristics for continuous-record stream-gaging stations on Tutuila, American Samoa--Continued

\section{Aasu Stream at Aasu.}

Location. - - Lat $14^{\circ} 17^{\prime} 51 \mathrm{M}$., long $170^{\circ} 45^{\prime} 30^{\prime \prime} \mathrm{W}$., on right bank at Aasu 200 ft upstream from mouth.

Drainage area. $--1.03 \mathrm{mi}^{2} \quad$ Tributary to.--Pacific Ocean.

Type of site.--Continuous-record station.

Period of record.--October 1958 - Present as of 1990

Mean discharge.--31 years (water years 1960-90), $6.09 \mathrm{ft}^{3} / \mathrm{s}$.

Extremes for period of record.--Maximum discharge, $498 \mathrm{ft}^{3} / \mathrm{s}$ on September 7, 1972; minimum, $0.12 \mathrm{ft}^{3} / \mathrm{s}$ on October $21,23,24,27,1974$.

\begin{tabular}{lcc}
\hline Streamflow & $\begin{array}{c}\text { Discharge } \\
\mathrm{ft}^{3} / \mathrm{S}\end{array}$ & $\begin{array}{c}\text { Accuracy } \\
\text { characteristic }\end{array}$ \\
\hline 7-day, 2-year low & 0.97 & 10.0 \\
7-day, 10-year low & 0.40 & 21.3 \\
Mean & 6.09 & 3.8 \\
Median & 4.10 & 6.2 \\
\hline
\end{tabular}

\begin{tabular}{lcccc}
\hline $\begin{array}{l}\text { Period } \\
\text { of con- } \\
\text { secutive } \\
\text { days }\end{array}$ & $\begin{array}{c}\text { Magnitude and frequency of annual low } \\
\text { flow for climatic years } 1960-90\end{array}$ \\
& $\begin{array}{c}\text { Discharge, in cubic feet per second, for } \\
\text { indicated recurrence interval, in years }\end{array}$ \\
\hline & & 5 & 10 & 20 \\
1 & 2 & 0.51 & 0.36 & 0.26 \\
7 & 0.87 & 0.56 & 0.40 & 0.28 \\
14 & 1.97 & 0.62 & 0.44 & 0.30 \\
30 & 1.5 & 0.76 & 0.60 & 0.44 \\
60 & 2.3 & 1.1 & 0.81 & 0.56 \\
90 & 2.7 & 1.5 & 1.0 & 0.75 \\
120 & 3.3 & 1.9 & 1.3 & 0.90 \\
183 & 4.5 & 2.9 & 2.1 & 1.6 \\
\hline
\end{tabular}


Table 1. Low-flow and high-flow characteristics for continuous-record stream-gaging stations on Tutuila, American Samoa--Continued

16920500 Aasu Stream at Aasu--continued.

\begin{tabular}{|c|c|c|c|c|c|}
\hline \multicolumn{6}{|c|}{$\begin{array}{l}\text { Duration table of daily flow } \\
\text { for water years 1960-1990 } \\
\text { Discharge, in cubic feet per second, which } \\
\text { was exceeded for indicated percentage of time }\end{array}$} \\
\hline Percent & 2 & 5 & 10 & 20 & 30 \\
\hline$f t^{3} / s$ & 28 & 18 & 13 & 8.6 & 6.6 \\
\hline Percent & 40 & 50 & 60 & 70 & 80 \\
\hline $\mathrm{ft}^{3} / \mathrm{s}$ & 5.2 & 4.1 & 3.3 & 2.6 & 2.1 \\
\hline Percent & 90 & 95 & 98 & 99 & 99.9 \\
\hline $\mathrm{ft}-\frac{3}{\mathrm{~s}} / \mathrm{s}$ & 1.4 & 1.0 & 0.65 & 0.45 & 0.15 \\
\hline
\end{tabular}

Index of variability $=0.335$

\begin{tabular}{lc}
\hline Period & Magnitude and frequency of annual high \\
of con- & flow for water years $1960-90$ \\
secutive & Discharge, in cubic feet per second, for \\
days & indicated recurrence interval, in years \\
\hline
\end{tabular}

\begin{tabular}{rrrrr} 
& 2 & 5 & 10 & 25 \\
\cline { 2 - 5 } 1 & 57 & 74 & 80 & 118 \\
7 & 28 & 35 & 40 & 49 \\
15 & 21 & 25 & 28 & 32 \\
30 & 15 & 18 & 19 & 21 \\
\hline
\end{tabular}

Remarks. --Small diversion above station for domestic use since the early $1960^{\prime}$ s. Diversion diminishing with time as villagers move out of valley. Only about 35 people were living in the valley in 1974 and only about 5 in 1990. Domestic diversion from spring in headwaters starting in 1968 (see 16919800). 
Table 1. Low-flow and high-flow characteristics for continuous-record stream-gaging stations on Tutuila, American Samoa--Continued

\section{Atauloma Stream at Afao.}

Location.--Lat $14^{\circ} 20^{\prime} 10^{\prime} \mathrm{S} .$, long $170^{\circ} 48^{\prime} 02^{\prime \prime} \mathrm{W} .$, on left bank at Afao, 100 ft upstream from highway bridge and 300 ft upstream from mouth.

Drainage area.--0.24 $\mathrm{mi}^{2} \quad$ Tributary to.--Pacific Ocean.

Type of site.--Continuous-record station.

Period of record.--October 1958 - Present as of 1990

Average discharge.--31 years (water years 1960-90), $1.45 \mathrm{ft}^{3} / \mathrm{s}$.

Extremes for period of record.--Maximum discharge, $815 \mathrm{ft}^{3} / \mathrm{s}$ on october 28, 1979; minimum, $0.04 \mathrm{ft}^{3} / \mathrm{s}$ on October $24-26,28-31$, and November 1,1974 .

\begin{tabular}{lcc}
\hline $\begin{array}{l}\text { Streamflow } \\
\text { characteristic }\end{array}$ & $\begin{array}{c}\text { Discharge } \\
\mathrm{ft}^{3} / \mathrm{s}\end{array}$ & $\begin{array}{c}\text { Accuracy } \\
\text { 8SE }\end{array}$ \\
\hline 7-day, 2-year low & 0.20 & 9.9 \\
7-day, 10-year low & 0.08 & 17.9 \\
Mean & 1.45 & 4.8 \\
Median & 0.69 & 8.0 \\
\hline
\end{tabular}

\begin{tabular}{|c|c|c|c|c|}
\hline $\begin{array}{l}\text { Period } \\
\text { of con- } \\
\text { secutive } \\
\text { days }\end{array}$ & \multicolumn{4}{|c|}{$\begin{array}{l}\text { Magnitude and frequency of annual low } \\
\text { flow for climatic years } 1960-90 \\
\text { Discharge, in cubic feet per second, for } \\
\text { indicated recurrence interval, in years }\end{array}$} \\
\hline & 2 & 5 & 10 & 20 \\
\hline 1 & 0.17 & 0.11 & 0.08 & 0.06 \\
\hline 7 & 0.20 & 0.11 & 0.08 & 0.07 \\
\hline 14 & 0.23 & 0.13 & 0.10 & 0.08 \\
\hline 30 & 0.28 & 0.17 & 0.13 & 0.10 \\
\hline 60 & 0.43 & 0.24 & 0.17 & 0.12 \\
\hline 90 & 0.51 & 0.29 & 0.22 & 0.15 \\
\hline 120 & 0.69 & 0.38 & 0.26 & 0.17 \\
\hline 183 & 1.0 & 0.56 & 0.38 & 0.24 \\
\hline
\end{tabular}


Table 1. Low-flow and high-flow characteristics for continuous-record stream-gaging stations on Tutuila, American Samoa--Continued

16931000 Atauloma stream at Afao--continued.

\begin{tabular}{|c|c|c|c|c|c|}
\hline \multicolumn{6}{|c|}{$\begin{array}{l}\text { Duration table of daily flow } \\
\text { for water years } 1960-1990 \\
\text { Discharge, in cubic feet per second, which } \\
\text { was exceeded for indicated percentage of time }\end{array}$} \\
\hline Percent & 2 & 5 & 10 & 20 & 30 \\
\hline $\mathrm{ft}^{3} / \mathrm{s}$ & 10 & 5.0 & 2.9 & 1.7 & 1.2 \\
\hline Percent & 40 & 50 & 60 & 70 & 80 \\
\hline $\mathrm{ft}^{3} / \mathrm{s}$ & 0.88 & 0.69 & 0.55 & 0.43 & 0.32 \\
\hline Percent & 90 & 95 & 98 & 99 & 99.9 \\
\hline $\mathrm{ft}^{3} / \mathrm{s}$ & 0.22 & 0.17 & 0.12 & 0.11 & 0.05 \\
\hline
\end{tabular}

Index of variability $=0.390$

\begin{tabular}{ll}
\hline Period & Magnitude and frequency of annual high \\
of con- & flow for water years 1960-90 \\
secutive & Discharge, in cubic feet per second, for \\
days & indicated recurrence interval, in years \\
\hline
\end{tabular}

\begin{tabular}{rrrrr} 
& 2 & 5 & 10 & 25 \\
\cline { 2 - 5 } 1 & 28 & 38 & 45 & 54 \\
7 & 8.9 & 13 & 16 & 18 \\
15 & 5.9 & 8.0 & 9.3 & 10 \\
30 & 4.0 & 5.4 & 5.8 & 6.7 \\
\hline
\end{tabular}

Remarks.--About $0.02 \mathrm{ft}^{3} / \mathrm{s}$ diverted upstream from station for domestic use in Afao since 1958 and at Atauloma School from 1958-1972. 
Table 1. Low-flow and high-flow characteristics for continuous-record stream-gaging stations on Tutuila, American Samoa--Continued

169315000 Asili stream at altitude 330 ft near Asili.

Location. - Lat $14^{\circ} 19^{\prime} 34^{\prime \prime S} .$, long $170^{\circ} 47^{\prime} 38^{\prime \prime} \mathrm{W} .$, on right bank 1.3 miles northwest of Leone, 1.5 miles southwest of Aoloaufou, and $0.8 \mathrm{mile}$ upstream from mouth.

Drainage area. $-0.32 \mathrm{mi}^{2}$ Tributary to.--Pacific Ocean.

Type of site.--Continuous- and partial-record station.

Period of record.--October 1977 - September 1986 as a continous station, 1987-90 as a partial-record station.

Mean discharge.--9 years (water years 1978-86), $2.54 \mathrm{ft}^{3} / \mathrm{s}$.

Extremes for period of record.--Maximum discharge, $635 \mathrm{ft}^{3} / \mathrm{s}$ on October 28, 1980; minimum, $0.20 \mathrm{ft}^{3} / \mathrm{s}$ on August 16, 1983.

Low-flow frequency.--As a partial-record site, only 8 climatic years of record.

\begin{tabular}{|c|c|c|}
\hline $\begin{array}{l}\text { Streamflow } \\
\text { characteristic }\end{array}$ & $\begin{array}{c}\text { Discharge } \\
\mathrm{ft}^{3} / \mathrm{s}\end{array}$ & $\begin{array}{c}\text { Accuracy } \\
\quad \therefore \text { SE }\end{array}$ \\
\hline 7-day, 2-year low & 0.47 & 10.8 \\
\hline 7-day, 10-year low & 0.24 & 22.5 \\
\hline Mean & 2.54 & 9.1 \\
\hline Median & 1.60 & 7.7 \\
\hline
\end{tabular}

Basis of estimate.--Graphical correlation with station 16920500 using 8 values of annual 7-day low flows.

Duration table of daily flow

for water years 1978-86

Discharge, in cubic feet per second, which was exceeded for indicated percentage of time

\begin{tabular}{llllll}
\hline Percent & 2 & 5 & 10 & 20 & 30
\end{tabular}

\begin{tabular}{crrrrr}
$\mathrm{ft}^{3} / \mathrm{s}$ & 13 & 8.1 & 5.5 & 3.4 & 2.4 \\
\hline Percent & 40 & 50 & 60 & 70 & 80
\end{tabular}

\begin{tabular}{crrrrr}
$\mathrm{ft}^{3} / \mathrm{s}$ & 1.9 & 1.6 & 1.3 & 1.1 & 0.88 \\
\hline Percent & 90 & 95 & 98 & 99 & 99.9
\end{tabular}

\begin{tabular}{llllll}
$\mathrm{ft}^{3} / \mathrm{s}$ & 0.66 & 0.51 & 0.34 & 0.28 & 0.22 \\
\hline
\end{tabular}

Index of variability $=0.318$ 
Table 1. Low-flow and high-flow characteristics for continuous-record stream-gaging stations on Tutuila, American Samoa--Continued

169315000 Asili Stream at Altitude 330 ft near Asili--continued.

\begin{tabular}{lcccc}
\hline $\begin{array}{l}\text { Period } \\
\text { of con- } \\
\text { secutive } \\
\text { days }\end{array}$ & $\begin{array}{c}\text { Magnitude and frequency of annul high } \\
\text { Discharge, in cubic feet per second, for } \\
\text { indicated recurrence interval, in years }\end{array}$ \\
\hline \multicolumn{6}{c}{} \\
\cline { 2 - 5 } 1 & 2 & 5 & 10 & 25 \\
7 & 12 & 36 & 42 & 51 \\
15 & 8.0 & 9.6 & 16 & 18 \\
30 & 5.9 & 7.1 & 7.7 & 11 \\
& & & & 8.2 \\
\hline
\end{tabular}

Remarks.--No diversions above station. List of measurements made, total of 11 during period when station was operated as a low-flow partialrecord station.

\begin{tabular}{|c|c|c|c|}
\hline Date & Discharge $\left(\mathrm{ft}^{3} / \mathrm{s}\right)$ & Date & Discharge $\left(\mathrm{ft}^{3} / \mathrm{s}\right)$ \\
\hline $07-14-77$ & ac2.11 & $06-05-87$ & 0.44 \\
\hline $08-18-77$ & $\mathrm{c} 0.34$ & $09-02-87$ & 0.42 \\
\hline $10-01-86$ & $\operatorname{ac} 5.6$ & $09-28-88$ & 0.47 \\
\hline $10-08-86$ & $\operatorname{ac} 2.0$ & $08-15-89$ & 0.28 \\
\hline $10-30-86$ & $\mathrm{c} 0.95$ & $08-07-90$ & 1.52 \\
\hline $12-02-86$ & c1.05 & & \\
\hline
\end{tabular}

a, includes surface runoff

c, not previously published 
Table 1. Low-flow and high-flow characteristics for continuous-record stream-gaging stations on Tutuila, American Samoa--Continued

169335000 Leafu Stream at altitude $370 \mathrm{ft}$, near Leone.

Location.--Lat $14^{\circ} 19^{\prime} 31^{\prime \prime S ., ~ l o n g ~} 170^{\circ} 46^{\prime} 50^{\prime \prime W}$., on left bank $900 \mathrm{ft}$ upstream from village stream intake, 1.3 miles northeast of Leone, and 1.0 mile southwest of Aoloaufou.

Drainage area. $--0.31 \mathrm{mi}^{2} \quad$ Tributary to.--Pacific Ocean.

Type of site.--Continuous- and partial-record station.

Period of record.--October 1977 - September 1986 as a continuous station, 1987-90 as a partial record station.

Mean discharge.--9 years (water years 1978-86), $4.56 \mathrm{ft}^{3} / \mathrm{s}$.

Extremes for period of record.--Maximum discharge, $400 \mathrm{ft}^{3} / \mathrm{s}$ on December 3, 1984; minimum, 0.32 $\mathrm{ft}^{3} / \mathrm{s}$ on August 9, 1983, and August 21, 1984.

Low-Flow frequency.--As a partial-record site. Only 8 climatic years of data.

\begin{tabular}{lcc}
\hline $\begin{array}{l}\text { Streamflow } \\
\text { characteristic }\end{array}$ & $\begin{array}{c}\text { Discharge } \\
\mathrm{ft}^{3} / \mathrm{s}\end{array}$ & $\begin{array}{c}\text { Accuracy } \\
\text { \%SE }\end{array}$ \\
\hline 7-day, 2-year low & 0.73 & 12.2 \\
7-day, 10-year low & 0.38 & 25.2 \\
Mean & 4.56 & 8.8 \\
Median & 2.50 & 10.6 \\
\hline
\end{tabular}

Basis of estimate.--Graphical correlation with station 16920500 using 8 values of annual 7-day lows.

Duration table of daily flow

for water years 1978-86

Discharge, in cubic feet per second, which was exceeded for indicated percentage of time

\begin{tabular}{cccccc}
\hline Percent & 2 & 5 & 10 & 20 & 30 \\
& & & & & \\
$\mathrm{ft}^{3} / \mathrm{s}$ & 25 & 16 & 9.6 & 5.8 & 4.1 \\
\hline Percent & 40 & 50 & 60 & 70 & 80
\end{tabular}

\begin{tabular}{crrrrr}
$\mathrm{ft}^{3} / \mathrm{s}$ & 3.1 & 2.5 & 2.1 & 1.8 & 1.4 \\
\hline Percent & 90 & 95 & 98 & 99 & 99.9
\end{tabular}

\begin{tabular}{llllll}
$\mathrm{ft}^{3} / \mathrm{s}$ & 1.1 & 0.78 & 0.56 & 0.46 & 0.40 \\
\hline
\end{tabular}

Index of variability $=0.338$ 
Table 1. Low-flow and high-flow characteristics for continuous-record stream-gaging stations on Tutuila, American Samoa--Continued

169335000 Leafu Stream at altitude $370 \mathrm{ft}$, near Leone--continued.

\begin{tabular}{lcccc}
\hline $\begin{array}{l}\text { Period } \\
\text { of con- } \\
\text { secutive } \\
\text { days }\end{array}$ & $\begin{array}{c}\text { Magnitude and frequency of annual high } \\
\text { flow for water years } 1977-86\end{array}$ \\
& $\begin{array}{l}\text { indicated recurrence interval, in years } \\
\text { indich }\end{array}$ \\
& 2 & 5 & 10 & 25 \\
1 & 50 & 64 & 74 & 87 \\
7 & 24 & 29 & 32 & 36 \\
15 & 16 & 20 & 23 & 25 \\
30 & 12 & 15 & 17 & 19 \\
\hline
\end{tabular}

Remarks.--No diversions above station. List of measurements made, total of 10, during period when station was operated as a low-flow partialrecord station.

\begin{tabular}{|c|c|c|c|}
\hline Date & Discharge $\left(\mathrm{ft}^{3} / \mathrm{s}\right)$ & Date & Discharge $\left(\mathrm{ft} \mathrm{t}^{3} / \mathrm{s}\right)$ \\
\hline $07-13-77$ & $\mathrm{c} 0.95$ & $06-02-87$ & 1.44 \\
\hline $08-19-77$ & $\mathrm{C} 0.33$ & $09-02-87$ & 0.98 \\
\hline $10-07-86$ & a3.81 & $09-28-88$ & 1.79 \\
\hline $10-28-86$ & 1.36 & $08-15-89$ & 1.40 \\
\hline $11-26-86$ & 2.28 & $08-07-90$ & 1.58 \\
\hline
\end{tabular}

a, includes surface runoff

c, not previously published 
Table 1. Low-flow and high-flow characteristics for continuous-record stream-gaging stations on Tutuila, American Samoa--Continued

\section{Papa Stream at Nuuuli.}

Location. - Lat $14^{\circ} 18^{\prime} 48^{\prime \prime S} .$, long $170^{\circ} 42^{\prime} 33^{\prime \prime} \mathrm{W}$. , on right bank $500 \mathrm{ft}$ downstream from Tauese stream 0.8 mile northwest of Nuuuli.

Drainage area. $--0.78 \mathrm{mi}^{2} \quad$ Tributary to.--Pacific Ocean.

Type of site.--Continuous- and partial-record station.

Period of record.--July 1966 - September 1967, November 1968 - September 1976 as a continuous-record station, 1968, 1977-78, 1981-83 as a partial-record station.

Mean discharge.--8 years (water years 1967, 1970-76), $4.18 \mathrm{ft}^{3} / \mathrm{s}$.

Extremes for period of record.--Maximum discharge, 1,640 $\mathrm{ft}^{3} / \mathrm{s}$ on April 29, 1975; minimum, no flow for many days each year.

Low-flow frequency. --As a partial-record station. Only 7 climatic years of data.

\begin{tabular}{lcc}
\hline Streamflow & $\begin{array}{c}\text { Discharge } \\
\mathrm{ft}^{3} / \mathrm{s}\end{array}$ & $\begin{array}{c}\text { Accuracy } \\
\text { characteristic }\end{array}$ \\
\hline 7-day, 2-year low & 0.18 & 31.6 \\
7-day, 10-year low & 0.04 & 44.0 \\
Mean & 4.18 & 6.8 \\
Median & 1.30 & 45.8 \\
\hline
\end{tabular}

Basis of estimate.--Moments approach with station 16920500 using 10 baseflow measurements.

Duration table of daily flow

for water years 1967, 1970-76

Discharge, in cubic feet per second, which was exceeded for indicated percentage of time

\begin{tabular}{cccccr}
\hline Percent & 2 & 5 & 10 & 20 & 30 \\
$\mathrm{Et}{ }^{3} / \mathrm{s}$ & 36 & 18 & 9.3 & 4.7 & 3.0 \\
\hline Percent & 40 & 50 & 60 & 70 & 80 \\
$\mathrm{Et}{ }^{3} / \mathrm{s}$ & 2.0 & 1.3 & 0.64 & 0.11 & 0.01 \\
\hline Percent & 90 & 95 & 98 & 99 & 99.9 \\
$\mathrm{Et}$ & & & & & \\
\hline
\end{tabular}

Index of variability $=1.04$ 
Table 1. Low-flow and high-flow characteristics for continuous-record stream-gaging stations on Tutuila, American Samoa--Continued

\section{Papa stream at Nuuuli.}

Remarks.--Diversion by frequent pumping from gage pool for public water supply during period of continuous record. No high-flow frequency done because of only 8 water years of data. However, 10 years of peakflow record is available for flood-frequency analysis. As a partialrecord station the measurements from 9-30-68 to 7-19-83 were previously published as belonging to station 16944000 . List of measurements, total of 11 , made during period when station operated as a low-flow partial-record site.

\begin{tabular}{|c|c|c|c|}
\hline Date & Discharge $\left(\mathrm{ft}^{3} / \mathrm{s}\right)$ & Date & Discharge $\left(\mathrm{ft}^{3} / \mathrm{s}\right)$ \\
\hline $05-03-68$ & $\mathrm{c} 1.83$ & $08-07-81$ & 1.50 \\
\hline $09-27-68$ & g0.05 & $09-24-81$ & 0.89 \\
\hline $09-30-68$ & 0.06 & $04-28-82$ & 0.40 \\
\hline $02-16-77$ & 0.60 & $10-26-82$ & 0.38 \\
\hline $08-24-77$ & 0.16 & $07-19-83$ & 0.07 \\
\hline $08-07-78$ & 0.31 & & \\
\hline
\end{tabular}

C, not previously published

$\mathrm{g}$, measurement made below diversion 
Table 1. Low-flow and high-flow characteristics for continuous-record stream-gaging stations on Tutuila, American Samoa--Continued

\section{Afuelo stream at Matuu.}

Location.--Lat $14^{\circ} 18^{\prime} 07^{\prime \prime S}$., long $170^{\circ} 41^{\prime} 07^{\prime \prime} \mathrm{W}$., on left bank 0.2 mile northwest of Matuu and 0.3 mile upstream from mouth.

Drainage area.--0.25 $\mathrm{mi}^{2} \quad$ Tributary to.--Pacific Ocean.

Type of site.--Continuous-record station.

Period of record.--March 1958 - Present as of 1990

Mean discharge.--14 years (water years 1959-72), $1.48 \mathrm{ft}^{3} / \mathrm{s}$. Since diversion began, 18 years (water years 1973-1990), $1.44 \mathrm{ft}^{3} / \mathrm{s}$.

Extremes for period of record.--Maximum discharge, $535 \mathrm{ft}^{3} / \mathrm{s}$ on May 3, 1985; minimum, $0.01 \mathrm{ft}^{3} / \mathrm{s}$ on September $16,17,20-26,28,29,1975$, April 5-7, 1976 and on September 17, 19, 20, 27, 28, 1990.

\begin{tabular}{lcc}
\hline Streamflow & $\begin{array}{c}\text { Discharge } \\
\mathrm{ft}^{3} / \mathrm{s}\end{array}$ & $\begin{array}{c}\text { Accuracy } \\
\text { characteristic }\end{array}$ \\
\hline 7-day, 2-year low & 0.04 & 16.6 \\
7-day, 10-year low & 0.02 & 27.8 \\
Mean (1973-90) & 1.44 & 8.1 \\
Median (1973-90) & 0.30 & 14.2 \\
\hline
\end{tabular}

\begin{tabular}{lcccc}
\hline $\begin{array}{l}\text { Period } \\
\text { of con- } \\
\text { secutive } \\
\text { days }\end{array}$ & $\begin{array}{r}\text { Magnitude and frequency of annual low } \\
\text { fischarge, in cubic feet per second, for } \\
\text { indicated recurrence interval, in years }\end{array}$ \\
\hline & \multicolumn{4}{l}{ climatic years $1974-90$} \\
1 & 0.04 & 0.02 & 0.01 & 0.01 \\
7 & 0.04 & 0.02 & 0.02 & 0.01 \\
14 & 0.06 & 0.03 & 0.02 & 0.02 \\
30 & 0.10 & 0.04 & 0.03 & 0.02 \\
60 & 0.23 & 0.06 & 0.04 & 0.03 \\
90 & 0.36 & 0.11 & 0.06 & 0.05 \\
120 & 0.47 & 0.20 & 0.10 & 0.06 \\
183 & 0.69 & 0.42 & 0.29 & 0.22 \\
\hline
\end{tabular}


Table 1. Low-flow and high-flow characteristics for continuous-record stream-gaging stations on Tutuila, American Samoa--Continued

16948000 Afuelo stream at Matuu--continued.

\begin{tabular}{|c|c|c|c|c|c|}
\hline \multicolumn{6}{|c|}{$\begin{array}{l}\text { Duration table of daily flow } \\
\text { for water years } 1959-1972 \\
\text { Discharge, in cubic feet per second, which } \\
\text { was exceeded for indicated percentage of time }\end{array}$} \\
\hline Percent & 2 & 5 & 10 & 20 & 30 \\
\hline $\mathrm{ft}^{3} / \mathrm{s}$ & 11 & 5.6 & 3.0 & 1.7 & 1.1 \\
\hline Percent & 40 & 50 & 60 & 70 & 80 \\
\hline $\mathrm{ft}^{3} / \mathrm{s}$ & 0.76 & 0.63 & 0.42 & 0.35 & 0.29 \\
\hline Percent & 90 & 95 & 98 & 99 & 99.9 \\
\hline $\mathrm{ft} \mathrm{t}^{3} / \mathrm{s}$ & 0.24 & 0.19 & 0.14 & 0.11 & 0.07 \\
\hline
\end{tabular}

Index of variability $=0.399$

Duration table of daily flow

for water years 1973-1990

Discharge, in cubic feet per second, which

was exceeded for indicated percentage of time

\begin{tabular}{llllll}
\hline Percent & 2 & 5 & 10 & 20 & 30
\end{tabular}

\begin{tabular}{rrrrrr}
$\mathrm{ft}^{3} / \mathrm{s}$ & 13 & 6.9 & 3.4 & 1.5 & 0.76 \\
\hline Percent & 40 & 50 & 60 & 70 & 80
\end{tabular}

\begin{tabular}{|c|c|c|c|c|c|}
\hline$f t^{3} / s$ & 0.47 & 0.30 & 0.20 & 0.14 & 0.10 \\
\hline Percent & 90 & 95 & 98 & 99 & 99.9 \\
\hline
\end{tabular}

\begin{tabular}{llllll}
$E t^{3} / \mathrm{S}$ & 0.06 & 0.05 & 0.03 & 0.02 & 0.01 \\
\hline
\end{tabular}

Index of variability $=0.606$ 
Table 1. Low-flow and high-flow characteristics for continuous-record stream-gaging stations on Tutuila, American Samoa--Continued

16948000 Afuelo stream at Matuu--Continued.

\begin{tabular}{|c|c|c|c|}
\hline $\begin{array}{l}\text { Period } \\
\text { of con- } \\
\text { secutive } \\
\text { days }\end{array}$ & \multicolumn{3}{|c|}{$\begin{array}{l}\text { Magnitude and frequency of annual high } \\
\text { flow for water years } 1959-90 \\
\text { Discharge, in cubic feet per second, for } \\
\text { indicated recurrence interval, in years }\end{array}$} \\
\hline & 5 & 10 & 25 \\
\hline 1 & 32 & 42 & 48 \\
\hline 7 & 13 & 15 & 16 \\
\hline 15 & 6.5 & 8.2 & 9.6 \\
\hline 30 & 4.6 & 5.6 & 6.0 \\
\hline
\end{tabular}

Remarks. --Small diversion $100 \mathrm{ft}$ upstream of station since september 1972 for domestic use. This diversion has made the entire data set unsuitable for low-flow frequency analysis, so only the $17 \mathrm{climatic}$ years after the diversion was used for low-flow frequency analysis. 
Table 1. Low-flow and high-flow characteristics for continuous-record stream-gaging stations on Tutuila, American Samoa--Continued

\section{Alega Stream at Alega.}

Location.--Lat $14^{\circ} 16^{\prime} 58^{\prime \prime S}$., long $170^{\circ} 38^{\prime} 19^{\prime \prime} \mathrm{W}$., on left bank 0.2 mile northwest of Alega and 0.3 mile upstream from mouth.

Drainage area.--0.19 $\mathrm{mi}^{2} \quad$ Tributary to.--Pacific Ocean.

Type of site.--Continuous- and partial-record station.

Period of record.--March 1958 - September 1976 as a continuous station, 1977-78, 1981-90, as a partial-record site.

Mean discharge.--18 years (water years 1959-76), $1.21 \mathrm{ft}^{3} / \mathrm{s}$.

Extremes for period of record.--Maximum discharge, $232 \mathrm{ft}^{3} / \mathrm{s}$ on April 8 , 1970; minimum, $0.17 \mathrm{ft}^{3} / \mathrm{s}$ on many days during July and August 1974 .

\begin{tabular}{lcc}
\hline $\begin{array}{l}\text { Streamflow } \\
\text { characteristic }\end{array}$ & $\begin{array}{c}\text { Discharge } \\
\mathrm{ft}^{3} / \mathrm{s}\end{array}$ & $\begin{array}{c}\text { Accuracy } \\
\text { \%SE }\end{array}$ \\
\hline 7-day, 2-year low & 0.42 & 10.0 \\
7-day, 10-year low & 0.23 & 20.2 \\
Mean & 1.21 & 4.5 \\
Median & 0.78 & 6.5 \\
\hline
\end{tabular}

\begin{tabular}{lcccc}
\hline $\begin{array}{l}\text { Period } \\
\text { of con- } \\
\text { secutive } \\
\text { days }\end{array}$ & $\begin{array}{c}\text { Magnitude and frequency of annual low } \\
\text { fischarge, in cubic feet per second, for } \\
\text { indicated recurrence interval, in years }\end{array}$ \\
\hline \multicolumn{5}{l}{$\begin{array}{l} \\
\end{array}$} \\
\cline { 2 - 5 } 1 & 0.41 & 0.27 & 0.22 & 0.18 \\
7 & 0.42 & 0.30 & 0.23 & 0.19 \\
14 & 0.43 & 0.30 & 0.24 & 0.20 \\
30 & 0.48 & 0.34 & 0.27 & 0.22 \\
60 & 0.58 & 0.40 & 0.32 & 0.25 \\
90 & 0.65 & 0.44 & 0.35 & 0.28 \\
120 & 0.71 & 0.49 & 0.39 & 0.31 \\
183 & 0.86 & 0.60 & 0.49 & 0.38 \\
\hline
\end{tabular}


Table 1. Low-flow and high-flow characteristics for continuous-record stream-gaging stations on Tutuila, American Samoa--Continued

\section{Alega Stream at Alega--continued.}

\begin{tabular}{|c|c|c|c|c|c|}
\hline \multicolumn{6}{|c|}{$\begin{array}{l}\text { Duration table of daily flow } \\
\text { for water years 1959-1976 } \\
\text { Discharge, in cubic feet per second, which } \\
\text { was exceeded for indicated percentage of time }\end{array}$} \\
\hline Percent & 2 & 5 & 10 & 20 & 30 \\
\hline $\mathrm{et} \mathrm{t}^{3} / \mathrm{s}$ & 5.9 & 3.5 & 2.3 & 1.5 & 1.1 \\
\hline Percent & 40 & 50 & 60 & 70 & 80 \\
\hline $\mathrm{et}^{3} / \mathrm{s}$ & 0.91 & 0.78 & 0.68 & 0.59 & 0.51 \\
\hline Percent & 90 & 95 & 98 & 99 & 99.9 \\
\hline $\mathrm{ft}^{3} / \mathrm{s}$ & 0.42 & 0.32 & 0.25 & 0.22 & 0.17 \\
\hline
\end{tabular}

Index of variability $=0.265$

\begin{tabular}{ll}
\hline Period & Magnitude and frequency of annual high \\
of con- & flow for water years $1960-90$ \\
secutive & Discharge, in cubic feet per second, for \\
days & indicated recurrence interval, in years \\
\hline
\end{tabular}

\begin{tabular}{rrrrr} 
& 2 & 5 & 10 & 25 \\
\cline { 2 - 5 } 1 & 16 & 22 & 24 & 26 \\
7 & 6.3 & 8.3 & 9.2 & 9.8 \\
15 & 4.2 & 5.5 & 5.9 & 6.5 \\
30 & 3.1 & 3.8 & 4.1 & 4.7 \\
\hline
\end{tabular}

Remarks.--No diversion above station. List of measurements, total of 23, made at station during period of operation as a low-flow partialrecord station.

\begin{tabular}{cccc} 
Date & Discharge $\left(\mathrm{ft}^{3} / \mathrm{s}\right)$ & Date & Discharge $\left(\mathrm{ft}^{3} / \mathrm{s}\right)$ \\
\cline { 1 - 1 } $10-25-76$ & $\mathrm{C} 0.34$ & $09-15-83$ & 0.30 \\
$11-27-76$ & 0.40 & $08-17-84$ & 0.27 \\
$12-27-76$ & $\mathrm{ac} 3.73$ & $08-07-85$ & 0.55 \\
$01-18-77$ & 0.55 & $09-06-85$ & 0.37 \\
$03-29-77$ & 0.64 & $08-08-86$ & 0.66 \\
$08-22-77$ & 0.39 & $05-21-87$ & 0.51 \\
$08-07-78$ & 0.49 & $09-15-87$ & 0.24 \\
$08-07-81$ & 0.88 & $09-22-88$ & 0.50 \\
$09-24-81$ & 0.84 & $07-19-89$ & 0.44 \\
$04-28-82$ & 0.58 & $09-27-89$ & 0.38 \\
$10-20-82$ & 0.46 & $07-19-90$ & 0.49 \\
$08-02-83$ & 0.26 & &
\end{tabular}

a, includes surface runoff

c, not previously published 
Table 1. Low-flow and high-flow characteristics for continuous-record stream-gaging stations on Tutuila, American Samoa--Continued

\section{Leafu Stream near Auasi.}

Location.--Lat $14^{\circ} 16^{\prime} 27^{\prime \prime S .}$, long $170^{\circ} 34 \cdot 25^{\prime \prime} \mathrm{W}$. , on right bank $35 \mathrm{ft}$ upstream from upper village intake, 0.1 mile north of Auasi and 0.2 mile upstream from mouth.

Drainage area.--0.11 $\mathrm{mi}^{2} \quad$ Tributary to.--Pacific Ocean.

Type of site.--Continuous- and partial-record station.

Period of record.--Febuary 1972 - September 1986 as a continuous station, 1987-90 as a partial-record station.

Mean discharge.--14 years (water years 1973-86), $0.32 \mathrm{ft}^{3} / \mathrm{s}$.

Extremes for period of record.--Maximum discharge $234 \mathrm{ft}^{3} / \mathrm{s}$ on December 5. 1980; minimum, $0.02 \mathrm{ft}^{3} / \mathrm{s}$ on several days in 1976 and many days in 1983,1984 .

\begin{tabular}{lcc}
\hline $\begin{array}{l}\text { Streamflow } \\
\text { characteristic }\end{array}$ & $\begin{array}{c}\text { Discharge } \\
\mathrm{ft}^{3} / \mathrm{s}\end{array}$ & $\begin{array}{c}\text { Accuracy } \\
\text { \%SE }\end{array}$ \\
\hline 7-day, 2-year low & 0.04 & 15.6 \\
7-day, 10-year low & 0.02 & 18.0 \\
Mean & 0.32 & 13.2 \\
Median & 0.11 & 17.2 \\
\hline
\end{tabular}

\begin{tabular}{|c|c|c|c|c|}
\hline $\begin{array}{l}\text { Period } \\
\text { of con- } \\
\text { secutive } \\
\text { days }\end{array}$ & \multicolumn{4}{|c|}{$\begin{array}{l}\text { Magnitude and frequency of annual low } \\
\text { flow for climatic years } 1973-86 \\
\text { Discharge, in cubic feet per second, for } \\
\text { indicated recurrence interval, in years }\end{array}$} \\
\hline & 2 & 5 & 10 & 20 \\
\hline 1 & 0.04 & 0.02 & 0.02 & 0.02 \\
\hline 7 & 0.04 & 0.02 & 0.02 & 0.02 \\
\hline 14 & 0.04 & 0.02 & 0.02 & 0.02 \\
\hline 30 & 0.05 & 0.03 & 0.02 & 0.02 \\
\hline 60 & 0.06 & 0.03 & 0.02 & 0.02 \\
\hline 90 & 0.08 & 0.04 & 0.03 & 0.02 \\
\hline 120 & 0.10 & 0.05 & 0.04 & 0.03 \\
\hline 183 & 0.14 & 0.07 & 0.05 & 0.04 \\
\hline
\end{tabular}


Table 1. Low-flow and high-flow characteristics for continuous-record stream-gaging stations on Tutuila, American Samoa--Continued

\section{Leafu Stream near Auasi--Continued.}

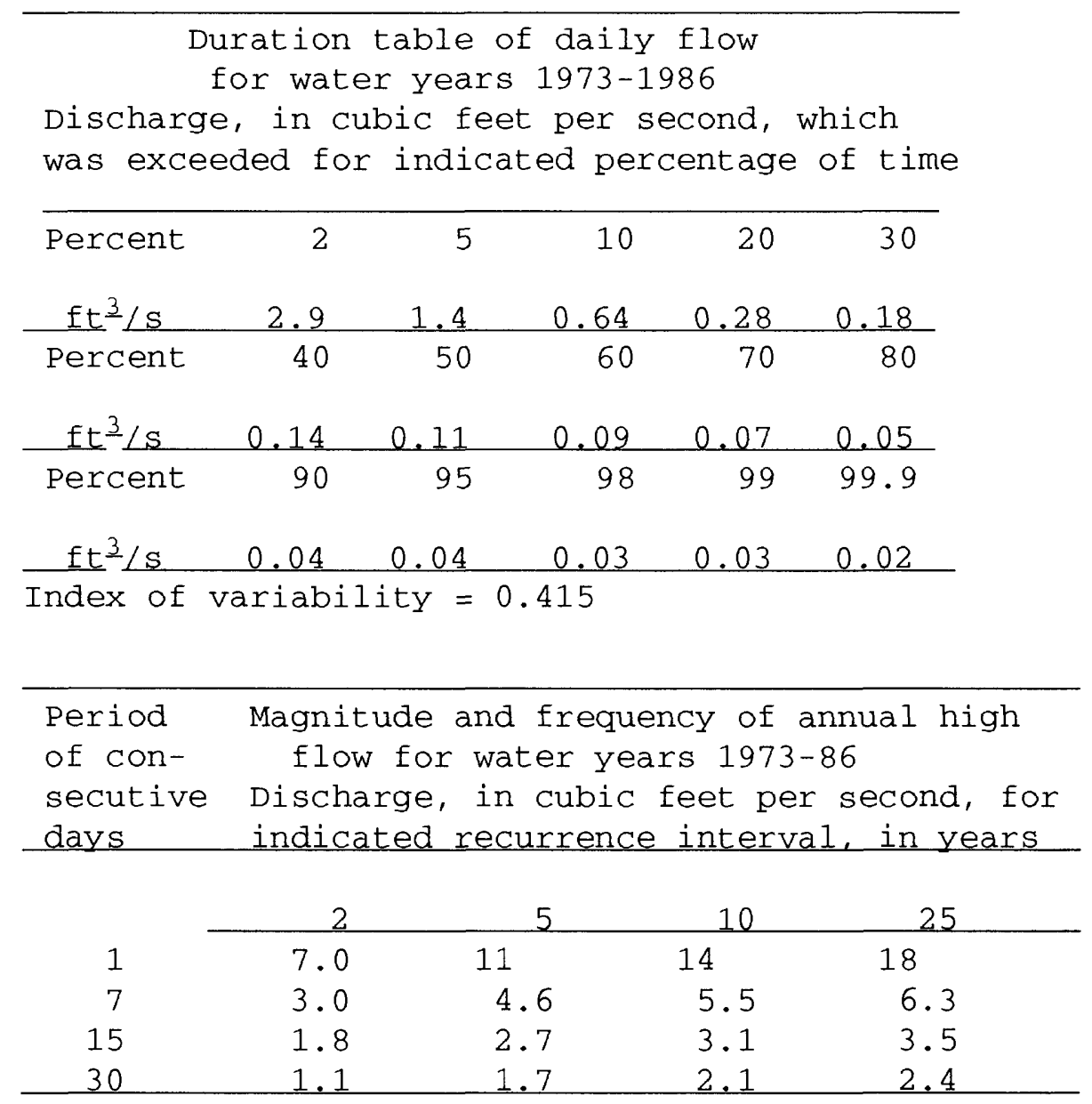

Remarks.--No diversion above station. List of measurements made, total of 8, during period of operation as a low-flow partial-record station.

$\begin{array}{cccc}\frac{\text { Date }}{10-30-86} & \text { Discharge }\left(\mathrm{ft}^{3} / \mathrm{s}\right) & \frac{\text { Date }}{09-22-88} & \text { Discharge (ft } \\ 11-75-86 & 0.05 & 07-19-89 & 0.04 \\ 05-21-87 & 0.04 & 09-27-89 & 0.05 \\ 09-15-87 & 0.05 & 07-19-90 & 0.04 \\ 0.03 & & 0.03\end{array}$


Table 3. Low-flow characteristics for low-flow partial-record stations on Tutuila, American Samoa

$$
16900000 \text { Vailoa stream at Tula. }
$$

Location.--Lat $14^{\circ} 15^{\prime} 33^{\prime \prime} \mathrm{S} .$, long $170^{\circ} 34^{\prime} 20^{\prime \prime} \mathrm{W} ., 0.5 \mathrm{mile}$ west of Tula and 0.6 mile upstream from mouth.

Drainage area. $-0.06 \mathrm{mi}^{2}$. Tributary to. - -N/A.

Type of site.--Low-flow partial-record station.

Period of record. $--1959-61,1963-65$.

\begin{tabular}{lcc}
\hline Streamflow & Discharge & Accuracy \\
characteristic & $\mathrm{ft}^{3} / \mathrm{s}$ & \%SE \\
\hline 7-day, 2-year low & 0.01 & 22.5 \\
7-day, 10-year low & $<0.01$ & 35.1 \\
Mean & 0.05 & 22.7 \\
Median & 0.02 & 14.5 \\
\hline
\end{tabular}

Basis of estimate.--Graphical correlation with station 16912000 .

List of measurements: total of 9 .

\begin{tabular}{|c|c|c|c|}
\hline Date & Discharge $\left(\mathrm{ft}^{3} / \mathrm{s}\right)$ & Date & Discharge $\left(\mathrm{ft}^{3} / \mathrm{s}\right)$ \\
\hline $10-29-58$ & 0.02 & $02-07-63$ & 0.03 \\
\hline $07-29-59$ & 0.01 & $02-18-63$ & b0. 04 \\
\hline $09-21-60$ & 0.02 & $05-18-64$ & 0.06 \\
\hline $09-28-60$ & 0.02 & $06-15-65$ & $\mathrm{a} 0.30$ \\
\hline $09-21-61$ & b0.01 & & \\
\hline
\end{tabular}
a, includes surface runoff
b, revision 
Table 3. Low-flow characteristics for low-flow partial-record stations on Tutuila, American Samoa--Continued

$$
16901000 \text { Left Fork Vaisa Stream at Onenoa. }
$$

Location,--Lat $14^{\circ} 15^{\prime} 30^{\prime \prime} \mathrm{S}$, , long $170^{\circ} 34^{\prime} 43^{\prime \prime} \mathrm{W},, 0.1$ mile upstream from confluence with Right Fork and 0.1 mile south of Onenoa.

Drainage area.--0.09 $\mathrm{mi}^{2}$. Tributary to.--Vaisa stream.

Type of site.--Low-flow partia1-record station.

Period of record.--1959-61, 1963, 1965, 1968.

\begin{tabular}{lcc}
\hline $\begin{array}{l}\text { Streamflow } \\
\text { characteristic }\end{array}$ & $\begin{array}{c}\text { Discharge } \\
\mathrm{ft}^{3} / \mathrm{s}\end{array}$ & $\begin{array}{c}\text { Accuracy } \\
\text { \%SE }\end{array}$ \\
\hline 7-day, 2-year low & 0.08 & 17.2 \\
7-day, 10-year low & 0.04 & 39.1 \\
Mean & 0.35 & 19.4 \\
Median & 0.18 & 12.9 \\
\hline
\end{tabular}

Basis of estimate.--Graphical correlation with station 16960000 .

Remarks.--Minor diversion upstream of site for domestic use starting about 1971 .

List of measurements: total of 11

\begin{tabular}{cccc} 
Date & Discharge $\left(\mathrm{ft}^{3} / \mathrm{s}\right)$ & Date & Discharge $\left(\mathrm{ft}^{3} / \mathrm{s}\right)$ \\
\hline $10-28-58$ & 0.10 & $09-28-61$ & 0.09 \\
$07-29-59$ & 0.10 & $02-07-63$ & 0.23 \\
$08-11-59$ & 0.09 & $02-18-63$ & 0.22 \\
$09-21-60$ & 0.11 & $06-15-65$ & $\mathrm{ab0} 0.65$ \\
$09-28-60$ & 0.09 & $05-02-68$ & $\mathrm{~b} 0.23$ \\
$09-21-61$ & 0.11 & &
\end{tabular}
a, includes surface runoff
b, revision 
Table 3. Low-flow characteristics for low-flow partial-record stations on Tutuila, American Samoa--Continued

\section{Right Fork Vaisa Stream at onenoa.}

Location.--Lat $14^{\circ} 15^{\prime} 27^{\prime \prime S ., ~ l o n g ~} 170^{\circ} 34^{\prime} 42^{\prime \prime W}$, , $100 \mathrm{ft}$ upstream from mouth and 0.1 mile southeast of Onenoa.

Drainage area.--0.03 $\mathrm{mi}^{2} \quad$ Tributary to.--Vaisa stream

Type of site.--Low-flow partial-record station.

Period of record.--1959-61, 1963.

\begin{tabular}{lcc}
\hline Streamflow & Discharge & Accuracy \\
characteristic & $\mathrm{ft}^{3} / \mathrm{s}$ & $\frac{8}{8} \mathrm{SE}$ \\
\hline 7-day, 2-year low & 0.02 & 17.2 \\
7-day, 10-year low & 0.01 & 42.8 \\
Mean & 0.08 & 25.4 \\
Median & 0.04 & 15.0 \\
\hline
\end{tabular}

Basis of estimate.--Graphical correlation with station 16960000 .

Remarks.--Validity of 11-16-1971 measurement in question, not used.

List of measurements: total of 10 .

\begin{tabular}{|c|c|c|c|}
\hline Date & Discharge $\left(\mathrm{ft}^{3} / \mathrm{s}\right)$ & Date & Discharge $\left(\mathrm{ft}^{3} / \mathrm{s}\right)$ \\
\hline $10-28-58$ & 0.02 & $09-21-61$ & 0.03 \\
\hline $07-29-59$ & 0.03 & $09-28-61$ & 0.02 \\
\hline $08-11-59$ & 0.03 & $02-07-63$ & b0. 04 \\
\hline $09-21-60$ & 0.03 & $02-18-63$ & 0.06 \\
\hline $09-28-60$ & 0.02 & $11-16-71$ & 0.38 \\
\hline
\end{tabular}

b, revision 
Table 3. Low-flow characteristics for low-flow partial-record stations on Tutuila, American Samoa--Continued

\section{Vaisa Stream at onenoa.}

Location.--Lat $14^{\circ} 15^{\prime} 26^{\prime \prime S .,}$ long $170^{\circ} 34^{\prime} 44^{\prime \prime} \mathrm{W} ., 30$ ft downstream from unnamed tributary, $0.1 \mathrm{mile}$ southeast of Onenoa, and 0.1 mile upstream from mouth (revision).

Drainage area.--0.12 $\mathrm{mi}^{2} \quad$ Tributary to.--Pacific Ocean

Type of site.--Low-flow partial-record station.

Period of record. $--1964-65,1968-69,1972,1974-76$.

\begin{tabular}{lcc}
\hline $\begin{array}{l}\text { Streamflow } \\
\text { characteristic }\end{array}$ & $\begin{array}{c}\text { Discharge } \\
\mathrm{ft}^{3} / \mathrm{s}\end{array}$ & $\begin{array}{c}\text { Accuracy } \\
8 \text { SE }\end{array}$ \\
\hline 7-day, 2-year low & 0.07 & 31.3 \\
7-day, 10-year low & 0.03 & 56.5 \\
Mean & 0.36 & 26.8 \\
Median & 0.25 & 20.2 \\
\hline
\end{tabular}

Basis of estimate.--Graphical correlation with station 16920500 .

Remarks.--Minor diversion upstream of site for domestic use starting in 1971.

List of measurements: total of 10 .

\begin{tabular}{cccc} 
Date & Discharge $\left(\mathrm{ft}^{3} / \mathrm{s}\right)$ & Date & Discharge $\left(\mathrm{ft}^{3} / \mathrm{s}\right)$ \\
\hline $05-14-64$ & 0.31 & $11-16-71$ & 0.11 \\
$05-18-64$ & 0.20 & $07-15-74$ & 0.13 \\
$06-15-65$ & ab0.49 & $11-13-74$ & 0.09 \\
$05-02-68$ & 0.37 & $09-30-75$ & 0.10 \\
$05-23-69$ & 0.29 & $09-13-76$ & 0.05
\end{tabular}

a, includes surface runoff

b, revision 
Table 3. Low-flow characteristics for low-flow partial-record stations on Tutuila, American Samoa--Continued

\section{Afimuao Stream at Onenoa.}

Location.-- Lat $14^{\circ} 15^{\prime} 34^{\prime \prime} \mathrm{S} .$, long $170^{\circ} 34^{\prime} 53^{\prime \prime} \mathrm{W} ., 200$ ft upstream from unnamed tributary, $0.2 \mathrm{mile}$ southwest of Onenoa, and $0.2 \mathrm{mile}$ upstream from mouth.

Drainage area.--0.06 $\mathrm{mi}^{2} \quad$ Tributary to.--Pacific Ocean

Type of site.--Low-flow partial-record station.

Period of record.--1959-61, 1963-65, 1968-69, 1974-76.

\begin{tabular}{lcc}
\hline Streamflow & $\begin{array}{c}\text { Discharge } \\
\mathrm{ft}^{3} / \mathrm{s}\end{array}$ & $\begin{array}{c}\text { Accuracy } \\
\text { \% SE }\end{array}$ \\
\hline 7-day, 2-year low & 0.02 & 27.4 \\
7-day, 10-year low & $<0.01$ & 38.5 \\
Mean & 0.13 & 32.0 \\
Median & 0.07 & 24.6 \\
\hline
\end{tabular}

Basis of estimate.--Moments approach with station 16920500 .

List of measurements: total of 18 .

\begin{tabular}{cccc} 
Date & Discharge $\left(\mathrm{ft}^{3} / \mathrm{s}\right)$ & Date & Discharge $\left(\mathrm{ft}^{3} / \mathrm{s}\right)$ \\
\cline { 1 - 2 } $10-28-58$ & 0.02 & $05-14-64$ & 0.06 \\
$07-29-59$ & $\mathrm{~b} 0.03$ & $05-18-64$ & 0.05 \\
$08-11-59$ & 0.03 & $06-15-65$ & $\mathrm{a} 0.43$ \\
$09-21-60$ & $\mathrm{~b} 0.04$ & $05-03-68$ & 0.19 \\
$09-28-60$ & 0.02 & $05-23-69$ & $\mathrm{c} 0.11$ \\
$09-21-61$ & 0.02 & $07-15-74$ & $\mathrm{c} 0.04$ \\
$09-28-61$ & 0.02 & $11-13-74$ & $\mathrm{c} 0.01$ \\
$02-07-63$ & 0.09 & $09-30-75$ & $\mathrm{c} 0.03$ \\
$02-18-63$ & 0.08 & $09-13-76$ & $\mathrm{c} 0.01$
\end{tabular}
$a$, includes surface runoff
b, revision
$c$, not previously published 
Table 3. Low-flow characteristics for low-flow partial-record stations on Tutuila, American Samoa--Continued

$$
16904000 \text { Laoulu Stream at Aoa. }
$$

Location.--Lat $14^{\circ} 15^{\prime} 54^{\prime \prime} \mathrm{S} .$, long $170^{\circ} 34^{\prime} 50^{\prime \prime} \mathrm{W} ., 0.2$ mile east of Aoa and 0.2 mile upstream of mouth.

Drainage area.--0.05 $\mathrm{mi}^{2} \quad$ Tributary to.--Pacific Ocean.

Type of site.--Low-flow partial-record station.

Period of record.--1959-61, 1963-65, 1968.

\begin{tabular}{lcc}
\hline $\begin{array}{l}\text { Streamflow } \\
\text { characteristic }\end{array}$ & $\begin{array}{c}\text { Discharge } \\
\mathrm{ft}^{3} / \mathrm{s}\end{array}$ & $\begin{array}{c}\text { Accuracy } \\
\text { oSE }\end{array}$ \\
\hline 7-day, 2-year low & 0.01 & 38.5 \\
7-day, 10-year low & $<0.01$ & 64.5 \\
Mean & 0.07 & 38.3 \\
Median & 0.03 & 21.9 \\
\hline
\end{tabular}

Basis of estimate.--Graphical correlation with station 16912000 .

List of measurements: total of 11 .

\begin{tabular}{|c|c|c|c|}
\hline Date & Discharge $\left(\mathrm{ft}^{3} / \mathrm{s}\right)$ & Date & Discharge $\left(\mathrm{ft}^{3} / \mathrm{s}\right)$ \\
\hline $10-17-58$ & 0.02 & $02-28-63$ & 0.02 \\
\hline $01-02-59$ & C0.09 & $02-21-63$ & 0.02 \\
\hline $07-29-59$ & 0.01 & $05-14-64$ & 0.05 \\
\hline $09-22-60$ & 0.02 & $06-16-65$ & $\mathrm{a} 0.11$ \\
\hline $09-29-60$ & do $(0.005)$ & $05-10-68$ & 0.02 \\
\hline $09-21-61$ & $\mathrm{~b} 0.01$ & & \\
\hline
\end{tabular}

\footnotetext{
a, includes surface runoff

b, revision

c, not previously published

d, measurements less than 0.01 cubic feet per second are published as 0
} 
Table 3. Low-flow characteristics for low-flow partial-record stations on Tutuila, American Samoa--Continued

\section{Lepa Stream at Aoa.}

Location.--Lat $14^{\circ} 16^{\prime} 21^{\prime \prime S} .$, long $170^{\circ} 35^{\prime} 17^{\prime \prime} \mathrm{W} ., 0.5$ mile upstream from mouth and 0.6 mile southwest of Aoa.

Drainage area.--0.09 $\mathrm{mi}^{2} \quad$ Tributary to.--Tapua stream.

Type of site.--Low-flow partial-record station.

Period of record.--1959-61, 1963-65, 1968-69, 1974-76.

\begin{tabular}{lcc}
\hline $\begin{array}{l}\text { Streamflow } \\
\text { characteristic }\end{array}$ & $\begin{array}{c}\text { Discharge } \\
\mathrm{ft}^{3} / \mathrm{S}\end{array}$ & $\begin{array}{c}\text { ACcuracy } \\
\text { \%SE }\end{array}$ \\
\hline 7-day, 2-year low & 0.03 & 16.1 \\
7-day, 10-year low & 0.01 & 18.9 \\
Mean & 0.29 & 19.4 \\
Median & 0.11 & 13.7 \\
\hline
\end{tabular}

Basis of estimate.--Moments approach with stations 16912000 and 16960000 .

List of measurements: total of 22 .

\begin{tabular}{|c|c|c|c|}
\hline Date & Discharge $\left(\mathrm{ft}^{3} / \mathrm{s}\right)$ & Date & Discharge $\left(\mathrm{ft}^{3} / \mathrm{s}\right)$ \\
\hline $10-17-58$ & 0.11 & $06-16-65$ & b0. 29 \\
\hline $07-29-59$ & 0.04 & $05-26-67$ & 0.19 \\
\hline $08-11-59$ & 0.06 & $05-10-68$ & 0.20 \\
\hline $09-22-60$ & $\mathrm{~b} 0.04$ & $10-09-68$ & $\mathrm{C} 0.06$ \\
\hline $09-29-60$ & $\mathrm{~b} 0.04$ & $09-12-70$ & 0.07 \\
\hline $09-21-61$ & 0.02 & $10-28-70$ & 0.05 \\
\hline $09-29-61$ & 0.03 & $05-04-71$ & 0.14 \\
\hline $02-08-63$ & b0 0.13 & $05-21-69$ & 0.13 \\
\hline $02-21-63$ & 0.08 & $03-11-74$ & 0.11 \\
\hline $05-14-64$ & $\mathrm{~b} 0.24$ & $11-12-74$ & 0.01 \\
\hline $05-20-64$ & e0.32 & $11-11-75$ & 0.02 \\
\hline
\end{tabular}

b, revision

c, not previously published

$e$, may include surface runoff 
Table 3. Low-flow characteristics for low-flow partial-record stations on Tutuila, American Samoa--Continued

16907000 Panota Stream at Masausi.

Location.--Lat $14^{\circ} 15^{\prime} 54^{\prime \prime S ., ~ l o n g ~} 170^{\circ} 36^{\prime} 09^{\prime \prime} \mathrm{W} ., 0.1$ mile southeast of Masausi and 0.2 mile upstream from mouth.

Drainage area. $--0.06 \mathrm{mi}^{2} \quad$ Tributary to.--Pacific Ocean

Type of site.--Low-flow partial-record station.

Period of record.--1959-60, 1962-64, 1968, 1970-71, 1974, 1976.

\begin{tabular}{lcc}
\hline $\begin{array}{l}\text { Streamflow } \\
\text { characteristic }\end{array}$ & $\begin{array}{c}\text { Discharge } \\
\mathrm{ft}^{3} / \mathrm{s}\end{array}$ & $\begin{array}{c}\text { Accuracy } \\
\% \mathrm{SE}\end{array}$ \\
\hline 7-day, 2-year low & 0.02 & 35.8 \\
7-day, 10-year low & 0.01 & 53.9 \\
Mean & 0.11 & 19.7 \\
Median & 0.07 & 13.8 \\
\hline
\end{tabular}

Basis of estimate.--Moments approach with station 16920500.

Remarks.--Minor diversion for domestic use upstream of site at $90 \mathrm{ft}$ altitude starting in 1968 .

List of measurements: total of 12 .

\begin{tabular}{cr} 
Date & Discharge $\left(\mathrm{ft}^{3} / \mathrm{s}\right)$ \\
\hline $11-04-58$ & 0.07 \\
$08-01-59$ & 0.04 \\
$09-26-60$ & $\mathrm{~b} 0.04$ \\
$10-04-61$ & 0.06 \\
$02-13-63$ & $\mathrm{~b} 0.13$ \\
$02-21-63$ & 0.09
\end{tabular}

$\begin{array}{cc}\frac{\text { Date }}{05-19-64} & \text { Discharge }\left(\mathrm{ft}^{3} / \mathrm{s}\right) \\ 05-07-68 & 0.57 \\ 09-12-70 & 0.10 \\ 10-20-70 & 0.09 \\ 03-15-74 & 0.04 \\ 11-11-75 & 0.08 \\ & 0.02\end{array}$

a, includes surface runoff

b, revision 
Table 3. Low-flow characteristics for low-flow partial-record stations on Tutuila, American Samoa--Continued

\section{Vaipito Stream at Masausi.}

Location.--Lat $14^{\circ} 16^{\prime} 05^{\prime \prime} \mathrm{S} .$, long $170^{\circ} 36^{\prime} 18^{\prime \prime} \mathrm{W} ., 0.2$ mile south of Masausi and 0.3 mile upstream from mouth.

Drainage area.--0.08 $\mathrm{mi}^{2} \quad$ Tributary to.--Pacific Ocean

Type of site.--Low-flow partial-record station.

Period of record.--1959-60, 1962-64, 1967-70, 1974, 1976.

\begin{tabular}{lcc}
\hline Streamflow & $\begin{array}{c}\text { Discharge } \\
\mathrm{ft}^{3} / \mathrm{s}\end{array}$ & $\begin{array}{c}\text { Accuracy } \\
\text { characteristic }\end{array}$ \\
\hline 7-day, 2-year low & 0.01 & 101 \\
7-day, 10-year low & $<0.01$ & 241 \\
Mean & 0.18 & 43.4 \\
Median & 0.07 & 28.3 \\
\hline
\end{tabular}

Basis of estimate.--Graphical correlation with station 16920500 .

List of measurements: total of 13 .

\begin{tabular}{|c|c|c|c|}
\hline Date & Discharge $\left(\mathrm{ft}^{3} / \mathrm{s}\right)$ & Date & Discharge $\left(\mathrm{ft}^{3} / \mathrm{s}\right)$ \\
\hline $11-04-58$ & 0.07 & $05-25-67$ & 0.11 \\
\hline $08-01-59$ & 0.05 & $05-07-68$ & 0.19 \\
\hline $09-26-60$ & 0.05 & $09-12-70$ & 0.07 \\
\hline $10-04-61$ & $\mathrm{~b} 0.01$ & $05-23-69$ & 0.22 \\
\hline $02-13-63$ & 0.06 & $03-15-74$ & 0.12 \\
\hline $02-21-63$ & bo .12 & $11-11-75$ & 0.01 \\
\hline $05-19-64$ & $\mathrm{a} 0.87$ & & \\
\hline
\end{tabular}

a, includes surface runoff

b, revision 
Table 3. Low-flow characteristics for low-flow partial-record stations on Tutuila, American Samoa--Continued

16909500 Talaloa Stream at Masefau Village.

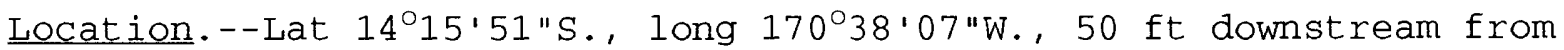
unnammed tributary, $0.5 \mathrm{mile}$ southwest of Masefau, and $0.5 \mathrm{mile}$ upstream from mouth.

Drainage area.--0.47 $\mathrm{mi}^{2} \quad$ Tributary to.--Pacific Ocean

Type of site.--Low-flow partial-record station.

Period of record.--1959-60, 1962-64, 1967-71, 1974, 1976.

\begin{tabular}{lcc}
\hline $\begin{array}{l}\text { Streamflow } \\
\text { Characteristic }\end{array}$ & $\begin{array}{c}\text { Discharge } \\
\mathrm{ft}^{3} / \mathrm{s}\end{array}$ & $\begin{array}{c}\text { Accuracy } \\
\text { \%SE }\end{array}$ \\
\hline 7-day, 2-year low & 0.19 & 33.5 \\
7-day, 10-year low & 0.08 & 60.4 \\
Mean & 0.83 & 30.6 \\
Median & 0.43 & 23.9 \\
\hline
\end{tabular}

Basis of estimate.--Graphical correlation with 16960000.

Remarks.--Measurement on 11-04-58 contains diverted flow from Tagau Stream. Flow diverted from Tagau stream into Talaloa Stream upstream from station from 1958 through the early 1960's. Minor diversion for domestic use upstream of site at altitude 120 ft from 1958.

List of measurements: total of 14 .

\begin{tabular}{cccc} 
Date & Discharge $\left(\mathrm{ft}^{3} / \mathrm{s}\right)$ & Date & Discharge $\left(\mathrm{ft}^{3} / \mathrm{s}\right)$ \\
\hline $11-04-58$ & 0.35 & $05-25-67$ & $\mathrm{~b} 0.69$ \\
$08-01-59$ & 0.46 & $05-07-68$ & 0.33 \\
$09-26-60$ & 0.12 & $09-12-70$ & 0.54 \\
$10-04-61$ & 0.29 & $10-20-70$ & 0.11 \\
$02-06-63$ & 0.74 & $05-23-69$ & 0.88 \\
$02-15-63$ & $\mathrm{~b} 1.03$ & $03-15-74$ & 0.14 \\
$05-19-64$ & $\mathrm{a} 4.97$ & $11-11-75$ & 0.06
\end{tabular}

a, includes surface runoff

b, revision 
Table 3. Low-flow characteristics for low-flow partial-record stations on Tutuila, American Samoa--Continued

\section{Tagau Stream at Masefau.}

Location.--Lat $14^{\circ} 15^{\prime} 47^{\prime \prime S ., ~ l o n g ~} 170^{\circ} 38^{\prime} 20^{\prime \prime W}$, 0.4 mile upstream from mouth and 0.6 mile southwest of Masefau.

Drainage area.--0.01 $\mathrm{mi}^{2} \quad$ Tributary to.--Talaloa Stream

Type of site.--Low-flow partial-record station.

Period of record. --1959-60, 1962-64, 1968, 1974, 1976.

\begin{tabular}{lcc}
\hline Streamflow & $\begin{array}{c}\text { Discharge } \\
\mathrm{ft}^{3} / \mathrm{s}\end{array}$ & $\begin{array}{c}\text { Accuracy } \\
\text { characteristic }\end{array}$ \\
\hline 7-day, 2-year low & 0.02 & 56.6 \\
7-day, 10-year low & $<0.01$ & 105 \\
Mean & 0.22 & 35.7 \\
Median & 0.12 & 23.3 \\
\hline
\end{tabular}

Basis of estimate.--Graphical correlation with station 16920500 .

List of measurements: total of 10 .

\begin{tabular}{|c|c|c|c|}
\hline Date & Discharge $\left(f t^{3} / s\right)$ & Date & Discharge $\left(\mathrm{ft}^{3} / \mathrm{s}\right)$ \\
\hline $11-04-58$ & 0.03 & $02-15-63$ & 0.16 \\
\hline $08-01-59$ & 0.02 & $05-19-64$ & $a 0.32$ \\
\hline $09-26-60$ & $\mathrm{~b} 0.04$ & $05-07-68$ & 0.23 \\
\hline $10-04-61$ & 0.05 & $03-15-74$ & 0.10 \\
\hline $02-06-63$ & 0.06 & $11-11-75$ & 0.02 \\
\hline
\end{tabular}

a, includes surface runoff

b, revision 
Table 3. Low-flow characteristics for low-flow partial-record stations on Tutuila, American Samoa--Continued

$$
16911000 \text { Pago Stream tributary at Afono. }
$$

Location.--Lat $14^{\circ} 16^{\prime} 07^{\prime \prime S ., ~ l o n g ~} 170^{\circ} 38^{\prime} 56^{\prime \prime W} ., 200$ ft upstream from mouth and 0.3 mile southeast of Afono.

Drainage area.--0.10 $\mathrm{mi}^{2} \quad$ Tributary to.--Pago Stream

Type of site.--Low-flow partial-record station.

Period of record. --1959-60, 1962-64, 1971, 1974-76.

\begin{tabular}{lcc}
\hline Streamflow & Discharge & $\begin{array}{c}\text { Accuracy } \\
\mathrm{ft}^{3} / \mathrm{S}\end{array}$ \\
characteristic & 0.07 & 33.0 \\
7-day, 2-year low & 0.03 & 67.9 \\
7-day, 10-year low & 0.42 & 42.8 \\
Mean & 0.28 & 30.7 \\
Median & 0
\end{tabular}

Basis of estimate.--Graphical correlation with station 16920500 .

List of measurements: total of 11 .

\begin{tabular}{cccc} 
Date & Discharge $\left(\mathrm{ft}^{3} / \mathrm{s}\right)$ & Date & Discharge $\left(\mathrm{ft}^{3} / \mathrm{s}\right.$ ) \\
\cline { 1 - 2 } $08-01-59$ & 0.22 & $05-19-64$ & ab1.15 \\
$08-07-59$ & 0.12 & $05-12-71$ & 0.10 \\
$09-26-60$ & 0.16 & $11-21-74$ & 0.13 \\
$10-04-61$ & 0.09 & $10-23-75$ & 0.06 \\
$02-06-63$ & 0.22 & & 0.05 \\
$02-15-63$ & 0.36 & &
\end{tabular}

a, includes surface runoff

b, revision 
Table 3. Low-flow characteristics for low-flow partial-record stations on Tutuila, American Samoa--Continued

$$
16913000 \text { Gaoa Stream at Vatia. }
$$

Location. --Lat $14^{\circ} 15^{\prime} 33^{\prime \prime S ., ~ l o n g ~} 170^{\circ} 40 \cdot 36^{\prime \prime} \mathrm{W} ., 0.3$ mile southwest of Vatia and 0.4 mile upstream from mouth.

Drainage area.--0.20 $\mathrm{mi}^{2} \quad$ Tributary to.--Leafu Stream.

Type of site.--Low-flow partial-record station.

Period of record.--1959-60, 1962-64, 1972 .

\begin{tabular}{lcc}
\hline $\begin{array}{l}\text { Streamflow } \\
\text { characteristic }\end{array}$ & $\begin{array}{c}\text { Discharge } \\
\mathrm{ft}^{3} / \mathrm{S}\end{array}$ & $\begin{array}{c}\text { Accuracy } \\
\% \mathrm{SE}\end{array}$ \\
\hline 7-day, 2-year low & 0.04 & 23.6 \\
7-day, 10-year low & 0.01 & 44.0 \\
Mean & 0.41 & 18.1 \\
Median & 0.26 & 15.4 \\
\hline
\end{tabular}

Basis of estimate.--Graphical correlation with station 16920500 .

Remarks. --Stream observed dry in October, 1974.

List of measurements: total of 8 .

\begin{tabular}{cccc} 
Date & Discharge $\left(\mathrm{ft}^{3} / \mathrm{s}\right)$ & Date & Discharge $\left(\mathrm{ft}^{3} / \mathrm{s}\right)$ \\
\hline $11-04-58$ & 0.33 & $02-06-63$ & $\mathrm{~b} 0.13$ \\
$08-08-59$ & 0.24 & $02-15-63$ & 0.26 \\
$09-26-60$ & 0.08 & $05-19-64$ & $\mathrm{a} 2.18$ \\
$10-28-61$ & 0.25 & $10-01-71$ & 0.02
\end{tabular}

a, includes surface runoff

b, revision 
Table 3. Low-flow characteristics for low-flow partial-record stations on Tutuila, American Samoa--Continued

\section{Leafu stream at Vatia.}

Location.--Lat $14^{\circ} 15^{\prime} 24^{\prime \prime S} .$, long $170^{\circ} 40^{\prime} 44^{\prime \prime} \mathrm{W} ., 0.3$ mile west of Vatia and 0.3 mile upstream from mouth.

Drainage area. $--0.18 \mathrm{mi}^{2} \quad$ Tributary to.--Pacific Ocean.

Type of site.--Low-flow partial-record station.

Period of record. --1959-60, 1962-64, 1970, 1972 .

\begin{tabular}{lcc}
\hline $\begin{array}{l}\text { Streamflow } \\
\text { characteristic }\end{array}$ & $\begin{array}{c}\text { Discharge } \\
\mathrm{ft}^{3} / \mathrm{S}\end{array}$ & $\begin{array}{c}\text { Accuracy } \\
\% S E\end{array}$ \\
\hline 7-day, 2-year low & 0.08 & 38.6 \\
7-day, 10-year low & 0.06 & 70.2 \\
Mean & 0.47 & 33.2 \\
Median & 0.25 & 25.3 \\
\hline
\end{tabular}

Basis of estimate.--Graphical correlation with station 16920500 .

List of measurements: total of 11 .

\begin{tabular}{cccc} 
Date & Discharge $\left(\mathrm{ft}^{3} / \mathrm{s}\right)$ & Date & Discharge $\left(\mathrm{ft}^{3} / \mathrm{s}\right)$ \\
\cline { 1 - 2 } $11-04-58$ & 0.37 & $02-06-63$ & $\mathrm{~b} 0.13$ \\
$08-01-59$ & 0.15 & $02-15-63$ & 0.42 \\
$09-26-60$ & 0.12 & $05-19-64$ & $\mathrm{a} 1.49$ \\
$10-04-61$ & 0.40 & $09-16-70$ & $\mathrm{a} 1.53$ \\
$10-04-61$ & $\mathrm{ac} 4.20$ & $10-01-71$ & 0.06 \\
$10-28-61$ & 0.19 & &
\end{tabular}
a, includes surface runoff
b, revision
c, not previously published 
Table 3. Low-flow characteristics for low-flow partial-record stations on Tutuila, American Samoa--Continued

\section{Leua Stream at Fagasa.}

Location.--Lat $14^{\circ} 17^{\prime} 24^{\prime} \mathrm{S} .$, long $170^{\circ} 43^{\prime} 00^{\prime \prime} \mathrm{W} ., 0.2$ mile northeast of Fagasa and 0.2 mile upstream from mouth.

Drainage area.--0.14 $\mathrm{mi}^{2} \quad$ Tributary to.--Pacific Ocean

Type of site.--Low-flow partia1-record station.

Period of record.--1959-61, 1963-65, 1968-71, 1974-75.

\begin{tabular}{lcc}
\hline $\begin{array}{l}\text { Streamflow } \\
\text { characteristic }\end{array}$ & $\begin{array}{c}\text { Discharge } \\
\text { ft }^{3} / \mathrm{s}\end{array}$ & $\begin{array}{c}\text { Accuracy } \\
\text { \%SE }\end{array}$ \\
\hline 7-day, 2-year 1ow & 0.04 & 30.3 \\
7-day, 10-year low & 0.01 & 40.4 \\
Mean & 0.34 & 45.3 \\
Median & 0.14 & 32.5 \\
\hline
\end{tabular}

Basis of estimate.--Moments approach with stations 16920500 and 16948000 .

Remarks.--Diversion by U.S. Marine Corps in the 1940's, no diversion during period of record.

List of measurements: tota1 of 18 .

\begin{tabular}{cc} 
Date & Discharge $\left(\mathrm{ft}^{3} / \mathrm{s}\right)$ \\
\hline $07-22-59$ & 0.29 \\
$08-04-59$ & 0.18 \\
$08-12-59$ & 0.07 \\
$09-28-60$ & $\mathrm{~b} 0.02$ \\
$10-04-60$ & $\mathrm{~b} 0.04$ \\
$09-20-61$ & 0.23 \\
$09-29-61$ & 0.03 \\
$02-04-63$ & 0.06 \\
$02-22-63$ & $\mathrm{~b} 0.04$
\end{tabular}

\begin{tabular}{cr} 
Date & Discharge $\left(\mathrm{ft}^{3} / \mathrm{s}\right)$ \\
\hline $05-15-64$ & $\mathrm{~b} 0.15$ \\
$06-14-65$ & $\mathrm{ab} 1.16$ \\
$04-30-68$ & 0.38 \\
$05-21-69$ & 0.31 \\
$09-13-70$ & 0.29 \\
$05-10-71$ & 0.13 \\
$03-12-74$ & 0.12 \\
$11-04-74$ & 0.01 \\
$09-23-75$ & 0.02
\end{tabular}

a, includes surface runoff

b, revision 
Table 3. Low-flow characteristics for low-flow partial-record stations on Tutuila, American Samoa--Continued

\section{Leele Stream at Fagasa.}

Location.--Lat $14^{\circ} 17^{\prime} 32^{\prime \prime S}$, long $170^{\circ} 43^{\prime} 01^{\prime \prime} \mathrm{W} ., 0.1$ mile southeast of Fagasa and 0.2 mile upstream from mouth.

Drainage area.--0.19 $\mathrm{mi}^{2} \quad$ Tributary to.--Pacific Ocean

Type of site.--Low-flow partial-record station.

Period of record.--1959-61, 1963-65, 1968, 1971, 1974-76.

\begin{tabular}{lcc}
\hline $\begin{array}{l}\text { Streamflow } \\
\text { characteristic }\end{array}$ & $\begin{array}{c}\text { Discharge } \\
\mathrm{ft}^{3} / \mathrm{s}\end{array}$ & $\begin{array}{c}\text { Accuracy } \\
\frac{\circ \mathrm{SE}}{}\end{array}$ \\
\hline 7-day, 2-year low & 0.13 & 21.7 \\
7-day, 10-year low & 0.04 & 30.1 \\
Mean & 1.10 & 27.6 \\
Median & 0.62 & 22.5 \\
\hline
\end{tabular}

Basis of estimate.--Moments approach with station 16920500 .

List of measurements: total of 17 .

\begin{tabular}{cccc} 
Date & Discharge $\left(\mathrm{ft}^{3} / \mathrm{s}\right)$ & $\frac{\text { Date }}{05-15-64}$ & Discharge $\left(\mathrm{ft}^{3} / \mathrm{s}\right)$ \\
\hline $07-22-59$ & 0.57 & $06-14-65$ & $\mathrm{~b} 0.32$ \\
$08-04-59$ & 0.66 & $04-30-68$ & $\mathrm{a} 2.03$ \\
$08-12-59$ & 0.25 & $05-10-71$ & 1.02 \\
$09-28-60$ & $\mathrm{~b} 0.24$ & $03-12-74$ & 0.58 \\
$10-04-60$ & $\mathrm{~b} 0.21$ & $11-04-74$ & 0.43 \\
$09-20-61$ & 0.39 & $09-23-75$ & 0.01 \\
$09-29-61$ & 0.16 & $09-27-76$ & 0.12 \\
$02-04-63$ & 0.34 & & 0.08 \\
$02-22-63$ & 0.39 & &
\end{tabular}

a, includes surface runoff

b, revision 
Table 3. Low-flow characteristics for low-flow partial-record stations on Tutuila, American Samoa--Continued

\section{Lesina Stream at Fagasa.}

Location.--Lat $14^{\circ} 17^{\prime} 37^{\mathrm{N}} \mathrm{S} .$, long $170^{\circ} 43^{\prime} 14 \mathrm{~W} \mathrm{~W} ., 0.1$ mile upstream from mouth and 0.2 mile southwest of Fagasa.

Drainage area.--0.02 $\mathrm{mi}^{2} \quad$ Tributary to.--Pacific Ocean

Type of site.--Low-flow partial-record station.

Period of record.--1959-61, 1963-65.

\begin{tabular}{lcc}
\hline Streamflow & Discharge & Accuracy \\
characteristic & $\mathrm{Et}^{3} / \mathrm{s}$ & \%SE \\
\hline 7-day, 2-year low & $<0.01$ & -- \\
7-day, 10-year low & 0 & -- \\
Mean & 0.22 & 64.1 \\
Median & 0.02 & 41.4 \\
\hline
\end{tabular}

Basis of estimate.--Graphical correlation with station 16948000 .

List of measurements: total of 10 .

\begin{tabular}{|c|c|c|c|}
\hline Date & Discharge $\left(\mathrm{ft}^{3} / \mathrm{s}\right)$ & Date & Discharge $\left(\mathrm{ft}^{3} / \mathrm{s}\right)$ \\
\hline $07-22-59$ & 0.07 & $09-20-61$ & $\mathrm{~d} 0 \quad(0.005)$ \\
\hline $08-04-59$ & 0.07 & $02-04-63$ & $\mathrm{~b} 0.01$ \\
\hline $08-12-59$ & 0.01 & $02-22-63$ & 0.02 \\
\hline $09-28-60$ & do $(0.003)$ & $05-15-64$ & 0.02 \\
\hline $10-04-60$ & $\mathrm{~d} 0 \quad(0.003)$ & $06-14-65$ & $\mathrm{ab} 0.25$ \\
\hline
\end{tabular}

a, includes surface runoff

b, revision

d, measurements less than 0.01 cubic feet per second are published as 0 
Table 3. Low-flow characteristics for low-flow partial-record stations on Tutuila, American Samoa--Continued

\section{Leaveave Stream near Aasu.}

Location. - Lat $14^{\circ} 18^{\prime} 28^{\prime \prime S} .$, long $170^{\circ} 45^{\prime} 06^{\prime \prime} \mathrm{W} ., 0.6$ mile upstream from mouth and 0.9 mile southeast of Aasu.

Drainage area. $--0.60 \mathrm{mi}^{2} \quad$ Tributary to.--Pacific Ocean

Type of site.--Low-flow partial-record station.

Period of record.--1959-60, 1962-63, 1968, 1974-76, 1979, 1981, 1983, $1986-87,1989-90$.

\begin{tabular}{lcc}
\hline $\begin{array}{l}\text { Streamflow } \\
\text { characteristic }\end{array}$ & $\begin{array}{c}\text { Discharge } \\
\mathrm{ft}^{3} / \mathrm{s}\end{array}$ & $\begin{array}{c}\text { Accuracy } \\
\text { \%SE }\end{array}$ \\
\hline 7-day, 2-year low & 0.75 & 11.7 \\
7-day, 10-year low & 0.32 & 21.7 \\
Mean & 3.46 & 12.8 \\
Median & 2.40 & 11.2 \\
\hline
\end{tabular}

Basis of estimate.--Moments approach with station 16920500 .

Remarks. - No villages in valley. U.S. Marine Corps used valley during the $1940^{\prime} \mathrm{s}$.

List of measurements: total of 22 .

\begin{tabular}{|c|c|c|c|}
\hline Date & Discharge $\left(\mathrm{ft}^{3} / \mathrm{s}\right)$ & Date & Discharge $\left(\mathrm{ft}^{3} / \mathrm{s}\right)$ \\
\hline $07-27-59$ & 1.14 & $10-30-78$ & 2.70 \\
\hline $08-14-59$ & 1.14 & $07-17-81$ & 1.70 \\
\hline $09-27-60$ & 1.24 & $09-03-81$ & e3.70 \\
\hline $10-03-61$ & $\mathrm{e} 2.12$ & $12-28-82$ & 0.66 \\
\hline $02-05-63$ & 1.62 & $08-16-83$ & 0.32 \\
\hline $02-16-63$ & 2.07 & $07-15-86$ & 1.04 \\
\hline $05-08-68$ & $\mathrm{e} 3.10$ & $07-10-87$ & 1.05 \\
\hline $08-14-74$ & 0.55 & $09-01-87$ & 1.50 \\
\hline $10-16-74$ & 0.18 & $08-11-89$ & 1.24 \\
\hline $11-04-75$ & 0.34 & $09-29-89$ & 0.41 \\
\hline $02-07-77$ & 3.00 & $07-18-90$ & 0.99 \\
\hline
\end{tabular}

e, may include surface runoff 
Table 3. Low-flow characteristics for low-flow partial-record stations on Tutuila, American Samoa--Continued

$$
16919200 \text { Leaveave Stream tributary No. } 2 \text { near Aasu. }
$$

Location. - - Lat $14^{\circ} 18^{\prime} 24^{\prime \prime S ., ~ l o n g ~} 170^{\circ} 45^{\prime} 03^{\prime \prime W}$, , 50 ft upstream from mouth and 0.8 mile southeast of Aasu.

Drainage area.--0.16 $\mathrm{mi}^{2} \quad$ Tributary to.--Leaveave Stream

Type of site.--Low-flow partial-record station.

Period of record. $--1960,1962-63,1968,1974-76$.

\begin{tabular}{lcc}
\hline $\begin{array}{l}\text { Streamflow } \\
\text { characteristic }\end{array}$ & $\begin{array}{c}\text { Discharge } \\
\mathrm{ft}^{3} / \mathrm{S}\end{array}$ & $\begin{array}{c}\text { ACCuracy } \\
\text { \%SE }\end{array}$ \\
\hline 7-day, 2-year low & 0.16 & 12.7 \\
7-day, 10-year low & 0.09 & 21.3 \\
Mean & 0.52 & 20.8 \\
Median & 0.40 & 17.3 \\
\hline
\end{tabular}

Basis of estimate.--Graphical correlation with station 16920500 .

List of measurements: total of 9 .

\begin{tabular}{|c|c|c|c|}
\hline Date & Discharge $\left(\mathrm{ft}^{3} / \mathrm{s}\right)$ & Date & Discharge $\left(\mathrm{ft}^{3} / \mathrm{s}\right.$ \\
\hline $09-27-60$ & 0.34 & $05-08-68$ & 0.39 \\
\hline $10-03-61$ & $a 0.51$ & $08-14-74$ & 0.13 \\
\hline $12-09-61$ & 0.25 & $10-16-74$ & 0.05 \\
\hline $02-05-63$ & $\mathrm{~b} 0.33$ & $11-04-75$ & 0.05 \\
\hline $02-16-63$ & $\mathrm{b0} 0.30$ & & \\
\hline
\end{tabular}

a, includes surface runoff

b, revision 
Table 3. Low-flow characteristics for low-flow partial-record stations on Tutuila, American Samoa--Continued

\section{Leaveave Stream tributary No. 1 near Aasu.}

Location.--Lat $14^{\circ} 18^{\prime} 21^{\prime \prime S} .$, long $170^{\circ} 45^{\prime} 01^{\prime \prime} \mathrm{W} ., 50$ ft upstream from mouth and 0.8 mile southeast of Aasu.

Drainage area.--0.15 $\mathrm{mi}^{2} \quad$ Tributary to.--Leaveave Stream

Type of site.--Low-flow partial-record station.

Period of record. $--1960,1962-63,1968,1974-76$.

\begin{tabular}{lcc}
\hline Streamflow & $\begin{array}{c}\text { Discharge } \\
\mathrm{ft}^{3} / \mathrm{s}\end{array}$ & $\begin{array}{c}\text { Accuracy } \\
\text { characteristic }\end{array}$ \\
\hline 7-day, 2-year low & 0.09 & 14.1 \\
7-day, 10-year low & 0.05 & 22.8 \\
Mean & 0.26 & 21.9 \\
Median & 0.21 & 18.4 \\
\hline
\end{tabular}

Basis of estimate.--Graphical correlation with station 16920500 .

List of measurements: total of 9 .

$\begin{array}{cccc}\text { Date } & \text { Discharge }\left(\mathrm{ft}^{3} / \mathrm{s}\right) & \frac{\text { Date }}{05-08-68} & \text { Discharge }\left(\mathrm{ft}^{3} / \mathrm{s}\right) \\ 09-27-60 & 0.11 & 08-14-74 & 0.16 \\ 10-03-61 & \mathrm{ac0} 0.70 & 10-16-74 & 0.07 \\ 12-09-61 & 0.16 & 11-04-75 & 0.03 \\ 02-05-63 & 0.17 & & 0.05 \\ 02-16-63 & 0.32 & & \end{array}$

a, includes surface runoff

$c$, not previously published 
Table 3. Low-flow characteristics for low-flow partial-record stations on Tutuila, American Samoa--Continued

$$
16919800 \text { Aasu Stream at Aoloaufou. }
$$

Location.--Lat $14^{\circ} 18^{\prime} 54^{\prime \prime S} .$, long $170^{\circ} 46^{\prime} 00^{\prime \prime} \mathrm{W} ., 0.3 \mathrm{mile}$ north of Aoloaufou and 1.3 miles southeast of Aoloautuai.

Drainage area. $--0.24 \mathrm{mi}^{2} \quad$ Tributary to.--Pacific Ocean

Type of site.--Low-flow partial-record station.

Period of record.--1960-65, 1968, 1974 .

\begin{tabular}{lcc}
\hline Streamflow & $\begin{array}{c}\text { Discharge } \\
\mathrm{ft}^{3} / \mathrm{s}\end{array}$ & $\begin{array}{c}\text { Accuracy } \\
\text { characteristic }\end{array}$ \\
\hline 7-day, 2-year low & 0.07 & 21.2 \\
7-day, 10-year low & 0.03 & 37.0 \\
Mean & 0.35 & 15.7 \\
Median & 0.24 & 12.8 \\
\hline
\end{tabular}

Basis of estimate.--Graphical correlation with station 16920500 .

Remarks.--Minor diversion from spring upstream of site for domestic use starting in 1968.

List of measurements: total of 10 .

\begin{tabular}{|c|c|c|c|}
\hline Date & Discharge $\left(\mathrm{ft}^{3} / \mathrm{s}\right)$ & Date & Discharge $\left(\mathrm{ft}^{3} / \mathrm{s}\right)$ \\
\hline $09-24-60$ & 0.12 & $02-20-63$ & 0.32 \\
\hline $10-03-60$ & 0.09 & $05-14-64$ & 0.16 \\
\hline $09-26-61$ & 0.05 & $06-18-65$ & 0.34 \\
\hline $10-02-61$ & bf 0.04 & $05-07-68$ & 0.91 \\
\hline $02-11-63$ & 0.23 & $07-16-74$ & $\mathrm{c} 0.07$ \\
\hline
\end{tabular}

b, revision

c, not previously published

$\mathrm{f}$, surface runoff at index station on this date 
Table 3. Low-flow characteristics for low-flow partial-record stations on Tutuila, American Samoa--Continued

\section{Aasu Stream near Aasu.}

Location.--Lat $14^{\circ} 18^{\prime} 16^{\prime S} \mathrm{~S}$, , long $170^{\circ} 45^{\prime} 29^{\prime \prime} \mathrm{W} ., 300$ ft downstream from 100-foot waterfall, $0.5 \mathrm{mile}$ south of Aasu, and 0.5 mile upstream from mouth.

Drainage area.--0.82 $\mathrm{mi}^{2} \quad$ Tributary to.--Pacifc Ocean

Type of site.--Low-flow partial-record station.

Period of record. --1959-63, 1968, 1974-76,1978-79, 1981, 1983, 1985-87, $1989-90$.

\begin{tabular}{lcc}
\hline $\begin{array}{l}\text { Streamflow } \\
\text { characteristic }\end{array}$ & $\begin{array}{c}\text { Discharge } \\
\mathrm{ft}^{3} / \mathrm{s}\end{array}$ & $\begin{array}{c}\text { Accuracy } \\
\text { \%SE }\end{array}$ \\
\hline 7-day, 2-year low & 0.92 & 11.7 \\
7-day, 10-year low & 0.39 & 21.6 \\
Mean & 4.09 & 12.8 \\
Median & 2.85 & 11.2 \\
\hline
\end{tabular}

Basis of estimate.--Moments approach with station 16920500 .

List of measurements: total of 26 .

\begin{tabular}{lccc} 
Date & Discharge $\left(\mathrm{ft}^{3} / \mathrm{s}\right)$ & Date & Discharge $\left(\mathrm{ft}^{3} / \mathrm{s}\right)$ \\
\cline { 1 - 2 } $07-29-59$ & 1.84 & $07-17-81$ & 1.90 \\
$08-14-59$ & 1.84 & $09-03-81$ & 4.60 \\
$09-27-60$ & $\mathrm{~b} 1.77$ & $12-28-82$ & 1.27 \\
$10-10-60$ & $\mathrm{~b} 1.20$ & $07-26-83$ & 0.48 \\
$10-03-61$ & $\mathrm{~b} 2.25$ & $08-16-83$ & 0.30 \\
$02-05-63$ & 2.55 & $09-17-85$ & 1.13 \\
$02-16-63$ & 3.40 & $07-15-86$ & 1.47 \\
$05-08-68$ & $\mathrm{e} .25$ & $07-10-87$ & 0.83 \\
$08-14-74$ & 0.79 & $09-01-87$ & 1.83 \\
$10-16-74$ & 0.21 & $07-21-89$ & 1.72 \\
$11-04-75$ & 0.56 & $09-29-89$ & 0.44 \\
$08-21-78$ & 2.42 & $07-18-90$ & 1.31 \\
$10-30-78$ & 2.90 & $08-21-90$ & 2.26 \\
b. revision & & & \\
e, may include surface runoff & &
\end{tabular}


Table 3. Low-flow characteristics for low-flow partial-record stations on Tutuila, American Samoa--Continued

\section{Vaisa Stream at Aoloautuai.}

Location.--Lat $14^{\circ} 18^{\prime} 15^{\prime S}$., long $170^{\circ} 47^{\prime} 00^{\prime \prime} \mathrm{W} ., 200 \mathrm{ft}$ below unnamed tributary, 0.3 mile upstream from vailolo stream, and 0.3 mile southwest of Aoloautuai.

Drainage area. $--0.78 \mathrm{mi}^{2}$. Tributary to.--Pacific Ocean

Type of site.--Low-flow partial-record station.

Period of record.--1959-60, 1962-63, 1965, 1968-69, 1974.

\begin{tabular}{lcc}
\hline Streamflow & $\begin{array}{c}\text { Discharge } \\
\text { characteristic }\end{array}$ & $\begin{array}{c}\text { Accuracy } \\
\text { \% } / \mathrm{SE}\end{array}$ \\
\hline 7-day, 2-year low & 0.74 & 21.1 \\
7-day, 10-year low & 0.28 & 40.9 \\
Mean & 5.40 & 19.9 \\
Median & 3.60 & 15.5 \\
\hline
\end{tabular}

Basis of estimate.--Graphical correlation with station 16920500 .

List of measurements: total of 9 .

\begin{tabular}{cccc} 
Date & Discharge $\left(\mathrm{ft}^{3} / \mathrm{s}\right)$ & $\frac{\text { Date }}{02-16-63}$ & Discharge $\left(\mathrm{ft}^{3} / \mathrm{s}\right)$ \\
\hline $07-27-59$ & $\mathrm{~b} 1.63$ & $05-08-68$ & $\mathrm{~b} 4.88$ \\
$08-14-59$ & $\mathrm{~b} 1.09$ & $05-21-69$ & 5.00 \\
$09-27-60$ & $\mathrm{~b} 1.40$ & $08-14-74$ & 0.55 \\
$10-03-61$ & $\mathrm{~b} 1.52$ & $\mathrm{~b} 0.61$ \\
$02-05-63$ & 2.71 & &
\end{tabular}

b, revision 
Table 3. Low-flow characteristics for low-flow partial-record stations on Tutuila, American Samoa--Continued

16923000 Vailolo stream at Aoloautuai.

Location. --Lat $14^{\circ} 18^{\prime} 22^{\prime \prime S ., ~ l o n g ~} 170^{\circ} 46^{\prime} 45^{\prime \prime} \mathrm{W} ., 100$ ft downstream from unnamed tributary, 0.4 mile upstream from mouth, and 0.4 mile south of Aoloautuai.

Drainage area.--0.18 $\mathrm{mi}^{2}$. Tributary to.--Pacific Ocean.

Type of site.--Low-flow partial-record station.

Period of record.--1959-60, 1962-63, 1968-69, 1974.

\begin{tabular}{lcc}
\hline $\begin{array}{l}\text { Streamflow } \\
\text { characteristic }\end{array}$ & $\begin{array}{c}\text { Discharge } \\
\mathrm{ft}^{3} / \mathrm{s}\end{array}$ & $\begin{array}{c}\text { Accuracy } \\
\% \mathrm{SE}\end{array}$ \\
\hline 7-day, 2-year low & 0.24 & 16.5 \\
7-day, 10-year low & 0.13 & 31.2 \\
Mean & 0.96 & 16.4 \\
Median & 0.70 & 12.4 \\
\hline
\end{tabular}

Basis of estimate.--Graphical correlation with station 16920500 .

Remarks. --Stream flows into Pacific Ocean, not into vaisa stream as shown on USGS topographic maps $(1963,1989)$. Noted by field observation in 1963.

List of measurements: total of 9 .

\begin{tabular}{|c|c|c|c|}
\hline Date & Discharge $\left(\mathrm{ft}^{3} / \mathrm{s}\right)$ & Date & Discharge $\left(\mathrm{ft}^{3} / \mathrm{s}\right)$ \\
\hline $07-27-59$ & $\mathrm{~b} 0.42$ & $02-16-63$ & 0.82 \\
\hline $08-14-59$ & $\mathrm{~b} 0.32$ & $05-08-68$ & 1.40 \\
\hline $09-27-60$ & b0 0.36 & $05-21-69$ & 0.53 \\
\hline $10-03-61$ & b0 0.39 & $08-14-74$ & b0 .19 \\
\hline $02-05-63$ & 0.57 & & \\
\hline
\end{tabular}


Table 3. Low-flow characteristics for low-flow partial-record stations on Tutuila, American Samoa--Continued

\section{Matavai Stream at Fagamalo.}

Location.--Lat $14^{\circ} 18^{\prime} 21^{\prime \prime S} .$, long $170^{\circ} 48^{\prime} 23^{\prime \prime} \mathrm{W} ., 0.2$ mile southeast of Fagamalo and 0.3 mile upstream from mouth.

Drainage area.--0.17 $\mathrm{mi}^{2} \quad$ Tributary to.--Pacific Ocean

Type of site.--Low-flow partial-record station.

Period of record.--1959-60, 1962-63, 1968, 1975.

\begin{tabular}{lcc}
\hline $\begin{array}{l}\text { Streamflow } \\
\text { characteristic }\end{array}$ & $\begin{array}{c}\text { Discharge } \\
\mathrm{ft}^{3} / \mathrm{s}\end{array}$ & $\begin{array}{c}\text { Accuracy } \\
8 \mathrm{SE}\end{array}$ \\
\hline 7-day, 2-year low & 0.16 & 18.2 \\
7-day, 10-year low & 0.07 & 31.8 \\
Mean & 0.90 & 21.9 \\
Median & 0.61 & 18.5 \\
\hline
\end{tabular}

Basis of estimate.--Graphical correlation with station 16920500 .

List of measurements: total of 8 .

\begin{tabular}{|c|c|c|c|}
\hline Date & Discharge $\left(f t^{3} / s\right)$ & Date & Discharge $\left(f t^{3} / s\right)$ \\
\hline $07-27-59$ & 0.23 & $02-05-63$ & 0.50 \\
\hline $08-14-59$ & 0.24 & $02-16-63$ & 0.71 \\
\hline $09-27-60$ & 0.36 & $05-07-68$ & 1.30 \\
\hline $10-03-61$ & 0.28 & $10-16-74$ & 0.03 \\
\hline
\end{tabular}


Table 3. Low-flow characteristics for low-flow partial-record stations on Tutuila, American Samoa--Continued

\section{Maloata Stream at Maloata.}

Location.--Lat $14^{\circ} 18^{\prime} 44^{\prime \prime S} .$, long $170^{\circ} 48^{\prime} 36^{\prime \prime W} ., 0.4$ mile southeast of Maloata and 0.4 mile upstream from mouth.

Drainage area.--0.74 $\mathrm{mi}^{2} \quad$ Tributary to.--Pacific Ocean

Type of site.--Low-flow partial-record station.

Period of record.--1959-60, 1962-63, 1968, 1975.

\begin{tabular}{lcc}
\hline Streamflow & $\begin{array}{c}\text { Discharge } \\
\text { characteristic }\end{array}$ & $\begin{array}{c}\text { Accuracy } \\
\mathrm{ft}^{3} / \mathrm{s}\end{array}$ \\
\hline 7-day, 2-year low & 0.90 & 13.3 \\
7-day, 10-year low & 0.52 & 23.2 \\
Mean & 5.00 & 7.6 \\
Median & 3.30 & 7.4 \\
\hline
\end{tabular}

Basis of estimate.--Graphical correlation with station 16920500 .

List of measurements: total of 8 .

\begin{tabular}{|c|c|c|c|}
\hline Date & Discharge $\left(\mathrm{Et}^{3} / \mathrm{s}\right)$ & Date & Discharge $\left(\mathrm{ft}^{3} / \mathrm{s}\right)$ \\
\hline $07-27-59$ & 1.30 & $02-05-63$ & 2.15 \\
\hline $08-14-59$ & 1.08 & $02-16-63$ & 3.23 \\
\hline $09-27-60$ & $\mathrm{~b} 1.54$ & $05-07-68$ & 4.9 \\
\hline $10-03-61$ & $\mathrm{~b} 1.37$ & $10-16-74$ & $\mathrm{~b} 0.28$ \\
\hline
\end{tabular}


Table 3. Low-flow characteristics for low-flow partial-record stations on Tutuila, American Samoa--Continued

16926000 Vaitele Stream at Poloa.

Location.--Lat $14^{\circ} 19^{\prime} 19^{\prime \prime} \mathrm{S} .$, long $170^{\circ} 49^{\prime} 35^{\prime \prime} \mathrm{W} ., 0.4$ mile east of Poloa and 0.6 mile upstream from mouth.

Drainage area.--0.11 $\mathrm{mi}^{2} \quad$ Tributary to.--Pacific Ocean

Type of site.--Low-flow partial-record station.

Period of record.--1959-61, 1963-64, 1969-70, 1974-75, 1977.

\begin{tabular}{lcc}
\hline Streamflow & $\begin{array}{c}\text { Discharge } \\
\mathrm{ft}^{3} / \mathrm{S}\end{array}$ & $\begin{array}{c}\text { Accuracy } \\
\text { characteristic }\end{array}$ \\
\hline 7-day, 2-year low & 0.05 & 25.2 \\
7-day, 10-year low & 0.02 & 41.8 \\
Mean & 0.28 & 36.8 \\
Median & 0.14 & 21.8 \\
\hline
\end{tabular}

Basis of estimate.--Graphical correlation with station 16912000.

List of measurements: total of 14 .

\begin{tabular}{|c|c|c|c|}
\hline Date & Discharge $\left(\mathrm{ft}^{3} / \mathrm{s}\right)$ & Date & Discharge $\left(\mathrm{ft}^{3} / \mathrm{s}\right)$ \\
\hline $07-28-59$ & 0.05 & $05-12-64$ & 0.12 \\
\hline $08-05-59$ & 0.05 & $05-26-69$ & 0.42 \\
\hline $09-23-60$ & b0.07 & $09-14-70$ & 0.49 \\
\hline $09-30-60$ & 0.06 & $07-31-74$ & 0.08 \\
\hline $09-25-61$ & b0. 04 & $08-23-74$ & 0.06 \\
\hline $02-09-63$ & 0.08 & $09-22-75$ & 0.14 \\
\hline $02-18-63$ & 0.09 & $11-22-76$ & $\mathrm{c} 0.05$ \\
\hline
\end{tabular}

b, revision

c, not previously published 
Table 3. Low-flow characteristics for low-flow partial-record stations on Tutuila, American Samoa--Continued

16927000 Puna Stream at Amanave.

Location.--Lat $14^{\circ} 19^{\prime} 39^{\prime \prime} \mathrm{S} .$, long $170^{\circ} 49^{\prime 4} 48^{\prime W} \mathrm{~W}, 0.2$ mile upstream from Maululu stream and 0.2 mile north of Amanave.

Drainage area.--0.03 $\mathrm{mi}^{2} \quad$ Tributary to.--Maululu stream

Type of site.--Low-flow partial-record station.

Period of record.--1959-61, 1963-65, 1968-69, 1974-75.

\begin{tabular}{lcc}
\hline $\begin{array}{l}\text { Streamflow } \\
\text { characteristic }\end{array}$ & $\begin{array}{c}\text { Discharge } \\
\mathrm{ft}^{3} / \mathrm{s}\end{array}$ & $\begin{array}{c}\text { Accuracy } \\
\% \text { SE }\end{array}$ \\
\hline 7-day, 2-year low & 0.04 & 19.2 \\
7-day, 10-year low & 0.01 & 26.9 \\
Mean & 0.26 & 18.8 \\
Median & 0.16 & 19.5 \\
\hline
\end{tabular}

Basis of estimate.--Moments approach with station 16920500 .

List of measurements: total of 15 .

\begin{tabular}{|c|c|c|c|}
\hline Date & Discharge $\left(f t^{3} / s\right)$ & Date & Discharge $\left(\mathrm{ft}^{3} / \mathrm{s}\right)$ \\
\hline$\overline{04-15-59}$ & $\mathrm{~b} 0.07$ & $\overline{05-12-64}$ & 0.17 \\
\hline $08-03-59$ & 0.22 & $05-20-64$ & $\mathrm{~b} 0.30$ \\
\hline $09-20-60$ & $\mathrm{~b} 0.04$ & $06-16-65$ & $\mathrm{a} 0.76$ \\
\hline $09-30-60$ & $\mathrm{~b} 0.04$ & $05-06-68$ & 0.55 \\
\hline $09-25-61$ & 0.02 & $05-26-69$ & 0.09 \\
\hline $09-30-61$ & 0.02 & $04-25-74$ & 0.06 \\
\hline $02-09-63$ & b0. 10 & $09-22-75$ & 0.07 \\
\hline $02-18-63$ & 0.09 & & \\
\hline
\end{tabular}

a, includes surface runoff

b, revision 
Table 3. Low-flow characteristics for low-flow partial-record stations on Tutuila, American Samoa--Continued

\section{Afutele Stream at Agugulu.}

Location.--Lat $14^{\circ} 20^{\prime} 05^{\prime \prime S}$., long $170^{\circ} 49^{\prime} 06^{\prime \prime} \mathrm{W} ., 30 \mathrm{ft}$ downstream from unnamed tributary at Agugulu and 0.1 mile upstream from mouth.

Drainage area.--0.17 $\mathrm{mi}^{2} \quad$ Tributary to.--Pacific Ocean

Type of site.--Low-flow partial-record station.

Period of record.--1959-61, 1963-65, 1968-71, 1974, 1976-77.

\begin{tabular}{lcc}
\hline $\begin{array}{l}\text { Streamflow } \\
\text { characteristic }\end{array}$ & $\begin{array}{c}\text { Discharge } \\
\mathrm{ft}^{3} / \mathrm{s}\end{array}$ & $\begin{array}{c}\text { Accuracy } \\
8 \mathrm{SE}\end{array}$ \\
\hline 7-day, 2-year low & 0.13 & 10.5 \\
7-day, 10-year low & 0.06 & 18.4 \\
Mean & 0.73 & 7.3 \\
Median & 0.38 & 8.0 \\
\hline
\end{tabular}

Basis of estimate.--Moments approach with station 16931000 .

List of measurements: total of 19 .

\begin{tabular}{cccc} 
Date & Discharge $\left(\mathrm{ft}^{3} / \mathrm{s}\right)$ & & Date \\
\cline { 1 - 1 } $04-29-59$ & 0.24 & $06-15-65$ & Discharge $\left(\mathrm{ft}^{3} / \mathrm{s}\right)$ \\
$08-03-59$ & 0.39 & $05-06-68$ & $\mathrm{~b} 1.36$ \\
$09-20-60$ & 0.28 & $05-26-69$ & 0.35 \\
$09-30-60$ & 0.23 & $09-14-70$ & 0.57 \\
$09-25-61$ & $\mathrm{~b} 0.15$ & $09-29-70$ & 0.59 \\
$09-30-61$ & $\mathrm{~b} 0.13$ & $07-09-71$ & 0.18 \\
$02-09-63$ & 0.31 & $04-25-74$ & 0.15 \\
$02-18-63$ & 0.37 & $09-28-76$ & 0.11 \\
$05-12-64$ & 0.48 & $11-22-76$ & $\mathrm{c} 0.08$ \\
$05-20-64$ & $\mathrm{~b} 0.55$ & &
\end{tabular}
a, includes surface runoff
b, revision
c, not previously published 
Table 3. Low-flow characteristics for low-flow partial-record stations on Tutuila, American Samoa--Continued

16929000 Vaialae Stream at utumea.

Location.--Lat $14^{\circ} 19 \cdot 56^{\prime} \mathrm{S} .$, long $170^{\circ} 48^{\prime} 50 \mathrm{~W} \mathrm{~W} ., 0.1$ mile north of utumea and 0.1 mile upstream from mouth.

Drainage area.--0.15 $\mathrm{mi}^{2} \quad$ Tributary to.--Pacific Ocean

Type of site.--Low-flow partial-record station.

Period of record.--1959-61, 1963-65, 1968-71, 1974, 1976-77.

\begin{tabular}{lcc}
\hline $\begin{array}{l}\text { Streamflow } \\
\text { characteristic }\end{array}$ & $\begin{array}{c}\text { Discharge } \\
\mathrm{ft}^{3} / \mathrm{s}\end{array}$ & $\begin{array}{c}\text { Accuracy } \\
\text { \%SE }\end{array}$ \\
\hline 7-day, 2-year low & 0.17 & 11.3 \\
7-day, 10-year low & 0.08 & 19.4 \\
Mean & 0.73 & 10.5 \\
Median & 0.41 & 8.8 \\
\hline
\end{tabular}

Basis of estimate.--Moments approach with station 16931000 .

List of measurements: total of 19 .

$\begin{array}{cccc}\text { Date } & \text { Discharge }\left(\mathrm{ft}^{3} / \mathrm{s}\right) & \frac{\text { Date }}{06-15-65} & \frac{\text { Discharge }\left(\mathrm{ft}^{3} / \mathrm{s}\right)}{\mathrm{ab} 1.00} \\ 04-29-59 & \mathrm{~b} 0.27 & 05-06-68 & \mathrm{a} 1.10 \\ 08-03-59 & 0.35 & 05-26-69 & 0.97 \\ 09-23-60 & \mathrm{~b} 0.33 & 09-14-70 & 0.56 \\ 09-30-60 & \mathrm{~b} 0.27 & 07-09-71 & 0.18 \\ 09-25-61 & \mathrm{~b} 0.18 & 04-25-74 & 0.15 \\ 09-30-61 & 0.16 & 09-22-75 & 0.16 \\ 02-09-63 & \mathrm{~b} 0.30 & 09-28-76 & 0.16 \\ 02-18-63 & 0.37 & 11-22-76 & \mathrm{c} 0.11 \\ 05-12-64 & 0.46 & & \end{array}$
a, includes surface runoff
b, revision
c, not previously published 
Table 3. Low-flow characteristics for low-flow partial-record stations on Tutuila, American Samoa--Continued

\section{Soonapule stream near Seetaga.}

Location.--Lat $14^{\circ} 19^{\prime} 42^{\prime S}$., long $170^{\circ} 48^{\prime} 36^{\prime \prime W}$., 50 ft upstream from Utanuatele Stream and 0.1 mile north of Seetaga.

Drainage area.--0.16 $\mathrm{mi}^{2} \quad$ Tributary to.--Pacific Ocean.

Type of site.--Low-flow partial-record station.

Period of record.--1959-61, 1963-64, 1968-71, 1974, 1976-77.

\begin{tabular}{lcc}
\hline $\begin{array}{l}\text { Streamflow } \\
\text { characteristic }\end{array}$ & $\begin{array}{c}\text { Discharge } \\
\mathrm{ft}^{3} / \mathrm{s}\end{array}$ & $\begin{array}{c}\text { Accuracy } \\
\text { \%SE }\end{array}$ \\
\hline 7-day, 2-year low & 0.11 & 16.4 \\
7-day, 10-year low & 0.04 & 22.1 \\
Mean & 1.05 & 17.7 \\
Median & 0.44 & 14.1 \\
\hline
\end{tabular}

Basis of estimate.--Moments approach with station 16931000 .

List of measurements: total of 18 .

\begin{tabular}{|c|c|c|c|}
\hline Date & Discharge $\left(\mathrm{ft}^{3} / \mathrm{s}\right)$ & Date & Discharge $\left(\mathrm{ft}^{3} / \mathrm{s}\right.$ \\
\hline $04-29-59$ & 0.24 & $05-20-64$ & 0.74 \\
\hline $08-03-59$ & 1.02 & $05-06-68$ & 1.34 \\
\hline $09-23-60$ & 0.20 & $05-20-69$ & 1.77 \\
\hline $09-30-60$ & b0.15 & $09-14-70$ & 0.56 \\
\hline $09-25-61$ & $\mathrm{~b} 0.10$ & $08-11-71$ & 0.14 \\
\hline $09-30-61$ & 0.11 & $04-25-74$ & 0.14 \\
\hline $02-09-63$ & 0.34 & $10-31-75$ & 0.06 \\
\hline $02-18-63$ & b0 .37 & $09-15-76$ & 0.08 \\
\hline $05-14-64$ & 0.45 & $11-22-76$ & $\mathrm{c} 0.08$ \\
\hline
\end{tabular}


Table 3. Low-flow characteristics for low-flow partial-record stations on Tutuila, American Samoa--Continued

\section{Utanuatele Stream at Seetaga.}

Location.--Lat $14^{\circ} 19^{\prime} 41^{\prime \prime S ., ~ l o n g ~} 170^{\circ} 48^{\prime} 35^{\prime \prime} \mathrm{W} ., 200 \mathrm{ft}$ upstream from mouth and 0.2 mile north of Seetaga.

Drainage area.--0.21 $\mathrm{mi}^{2}$. Tributary to.--Soonapule Stream.

Type of site.--Low-flow partial-record station.

Period of record.--1960-61, 1963-64, 1968-71, 1974, 1976-77.

\begin{tabular}{lcc}
\hline $\begin{array}{l}\text { Streamflow } \\
\text { characteristic }\end{array}$ & $\begin{array}{c}\text { Discharge } \\
\mathrm{ft}^{3} / \mathrm{s}\end{array}$ & $\begin{array}{c}\text { Accuracy } \\
\text { \%SE }\end{array}$ \\
\hline 7-day, 2-year low & 0.07 & 19.1 \\
7-day, 10-year low & 0.02 & 26.0 \\
Mean & 1.00 & 18.1 \\
Median & 0.36 & 15.4 \\
\hline
\end{tabular}

Basis of estimate.--Moments approach with station 16931000 .

Remarks.--Minor diversion for domestic use upstream of site at $100 \mathrm{ft}$ altitude starting about 1968 .

List of measurements: total of 15 .

\begin{tabular}{|c|c|c|c|}
\hline Date & Discharge $\left(\mathrm{ft}^{3} / \mathrm{s}\right)$ & Date & Discharge $\left(\mathrm{ft}^{3} / \mathrm{s}\right)$ \\
\hline $09-23-60$ & b0. 24 & $05-06-68$ & e1.86 \\
\hline $09-30-60$ & 0.16 & $05-20-69$ & 1.06 \\
\hline $09-25-61$ & b0.10 & $09-14-70$ & 0.60 \\
\hline $09-30-61$ & 0.09 & $08-11-71$ & 0.10 \\
\hline $02-09-63$ & 0.28 & $04-25-74$ & 0.06 \\
\hline $02-18-63$ & 0.32 & $09-15-76$ & 0.03 \\
\hline $05-12-64$ & 0.53 & $11-22-76$ & $\mathrm{C} 0.04$ \\
\hline $05-20-64$ & 0.71 & & \\
\hline
\end{tabular}

b, revision

$c$, not previously published

e, may include surface runoff 
Table 3. Low-flow characteristics for low-flow partial-record stations on Tutuila, American Samoa--Continued

\section{Asili Stream near Asili.}

Location.--Lat $14^{\circ} 19^{\prime} 46^{\prime \prime S ., ~ l o n g ~} 170^{\circ} 47^{\prime} 42^{\prime \prime} \mathrm{W} ., 0.4$ mile north of Asili and 0.5 mile upstream from mouth.

Drainage area.--0.55 $\mathrm{mi}^{2}$. Tributary to.--Pacific Ocean.

Type of site.--Low-flow partial-record station.

Period of record.--1959-61, 1963-65, 1968, 1970, 1974-77, 1981-82, 1984.

\begin{tabular}{lcc}
\hline $\begin{array}{l}\text { Streamflow } \\
\text { characteristic }\end{array}$ & $\begin{array}{c}\text { Discharge } \\
\mathrm{ft}^{3} / \mathrm{s}\end{array}$ & $\begin{array}{c}\text { Accuracy } \\
\% S E\end{array}$ \\
\hline 7-day, 2-year low & 0.68 & 18.2 \\
7-day, 10-year low & 0.25 & 25.8 \\
Mean & 2.76 & 23.0 \\
Median & 1.85 & 17.9 \\
\hline
\end{tabular}

Basis of estimate.--Moments approach with station 16920500 .

List of measurements: total of 24 .

\begin{tabular}{|c|c|c|c|}
\hline Date & Discharge $\left(\mathrm{ft}^{3} / \mathrm{s}\right)$ & Date & Discharge $\left(\mathrm{ft} \mathrm{t}^{3} / \mathrm{s}\right)$ \\
\hline$\overline{07-22-59}$ & 1.52 & $09-14-70$ & 1.99 \\
\hline $08-05-59$ & 1.77 & $04-25-74$ & 0.89 \\
\hline $09-23-60$ & b0 .91 & $11-21-74$ & 1.83 \\
\hline $10-01-60$ & $\mathrm{~b} 0.78$ & $09-25-75$ & $\mathrm{~b} 0.97$ \\
\hline $09-25-61$ & 0.51 & $09-15-76$ & 0.76 \\
\hline $09-30-61$ & 0.51 & $11-23-76$ & c1. 61 \\
\hline $02-09-63$ & 1.28 & $01-26-77$ & $\mathrm{f} 0.98$ \\
\hline $02-18-63$ & $\mathrm{~b} 2.36$ & $03-28-77$ & 2.62 \\
\hline $05-12-64$ & 1.69 & $08-05-81$ & 1.80 \\
\hline $05-20-64$ & 2.51 & $09-30-81$ & 1.03 \\
\hline $06-16-65$ & a 6.01 & $05-07-82$ & 0.45 \\
\hline $05-06-68$ & a 5.67 & $08-22-84$ & 0.11 \\
\hline
\end{tabular}

a, includes surface runoff

b, revision

c, not previously published

$\mathrm{f}$, surface runoff at index station on this date 
Table 3. Low-flow characteristics for low-flow partial-record stations on Tutuila, American Samoa--Continued

\section{Asili Stream at Asili.}

Location.--Lat $14^{\circ} 20^{\prime} 04 \mathrm{MS} .$, long $170^{\circ} 47^{\prime} 40^{\prime \prime} \mathrm{W} ., 100$ ft upstream from highway bridge at Asili and 0.1 mile upstream from mouth.

Drainage area. $--0.66 \mathrm{mi}^{2} \quad$ Tributary to.--Pacific Ocean

Type of site.--Low-flow partial-record station.

Period of record.--1958-59h, 1960-61, 1963-65, 1967-69, 1972, 1974-77, $1981-85,1987-90$.

\begin{tabular}{lcc}
\hline $\begin{array}{l}\text { Streamflow } \\
\text { characteristic }\end{array}$ & $\begin{array}{c}\text { Discharge } \\
\mathrm{ft}^{3} / \mathrm{s}\end{array}$ & $\begin{array}{c}\text { Accuracy } \\
\text { \%SE }\end{array}$ \\
\hline 7-day, 2-year low & 0.58 & 13.9 \\
7-day, 10-year low & 0.21 & 17.6 \\
Mean & 5.73 & 14.5 \\
Median & 2.85 & 10.9 \\
\hline
\end{tabular}

Basis of estimate.--Moments approach with stations 16920500 and 16931000 .

List of measurements: total of 34 .

\begin{tabular}{cc} 
Date & Discharge $\left(\mathrm{ft}^{3} / \mathrm{s}\right)$ \\
\hline $07-22-59$ & 2.11 \\
$08-05-59$ & 2.30 \\
$09-23-60$ & 0.96 \\
$10-01-60$ & $\mathrm{~b} 0.95$ \\
$09-25-61$ & 0.60 \\
$09-30-61$ & 0.54 \\
$02-09-63$ & $\mathrm{~b} 1.63$ \\
$02-18-63$ & 2.37 \\
$05-12-64$ & 2.21 \\
$05-20-64$ & 3.11 \\
$06-16-65$ & $\mathrm{a} 6.87$ \\
$05-25-67$ & 3.48 \\
$05-06-68$ & $\mathrm{a} 7.09$ \\
$05-20-69$ & 5.93 \\
$05-26-69$ & 2.77 \\
$11-17-71$ & 1.30 \\
$04-25-74$ & 1.07
\end{tabular}

\begin{tabular}{cc} 
Date & Discharge fft $^{3} / \mathrm{s}$ ) \\
\hline $09-25-75$ & $\mathrm{~b} 1.14$ \\
$09-15-76$ & 0.54 \\
$11-23-76$ & $\mathrm{c} 1.40$ \\
$01-26-77$ & $\mathrm{f} 0.96$ \\
$03-28-77$ & 2.28 \\
$08-05-81$ & 2.17 \\
$09-30-81$ & 1.05 \\
$05-07-82$ & 0.59 \\
$07-12-83$ & 0.34 \\
$08-09-83$ & 0.26 \\
$08-22-84$ & 0.30 \\
$08-13-85$ & 0.90 \\
$06-05-87$ & 0.97 \\
$09-02-87$ & 0.68 \\
$09-28-88$ & 1.14 \\
$08-15-89$ & 1.02 \\
$08-07-90$ & 1.32
\end{tabular}

a, includes surface runoff

b, revision

c, not previously published

$\mathrm{f}$, surface runoff at index station on this date

$h$, operated as a continuous-gaging station 
Table 3. Low-flow characteristics for low-flow partial-record stations on Tutuila, American Samoa--Continued

\section{Vaipuna Stream at Amaluia.}

Location.--Lat $14^{\circ} 19^{\prime} 48^{\prime \prime S} .$, long $170^{\circ} 47 \cdot 20^{\prime \prime W} ., 300$ ft upstream from unnamed tributary, $0.6 \mathrm{mile}$ north of Amaluia, and 0.7 mile upstream from mouth.

Drainage area. $-0.08 \mathrm{mi}^{2} \quad$ Tributary to.--Pacific Ocean

Type of site.--Low-flow partial-record station.

Period of record.--1959-61, 1963-65, 1972 .

\begin{tabular}{lcc}
\hline Streamflow & $\begin{array}{c}\text { Discharge } \\
\text { characteristic }\end{array}$ & $\begin{array}{c}\text { Accuracy } \\
\mathrm{ft}^{3} / \mathrm{s}\end{array}$ \\
\hline 7-day, 2-year low & 0.06 & 28.0 \\
7-day, 10-year low & 0.02 & 49.0 \\
Mean & 0.35 & 27.4 \\
Median & 0.24 & 22.3 \\
\hline
\end{tabular}

Basis of estimate.--Graphical correlation with station 16920500 .

List of measurements: total of 11 .

\begin{tabular}{cccc} 
Date & Discharge $\left(\mathrm{ft}^{3} / \mathrm{s}\right)$ & Date & Discharge $\left(\mathrm{ft}^{3} / \mathrm{s}\right)$ \\
\hline $07-23-59$ & 0.16 & $02-12-63$ & $\mathrm{e} 0.45$ \\
$08-05-59$ & 0.24 & $02-19-63$ & 0.26 \\
$09-24-60$ & $\mathrm{~b} 0.07$ & $05-15-64$ & $\mathrm{~b} 0.15$ \\
$10-03-60$ & 0.05 & $06-16-65$ & $\mathrm{a} 0.68$ \\
$09-27-61$ & 0.03 & $10-01-71$ & 0.56 \\
$09-30-61$ & 0.05 & &
\end{tabular}
$a$, includes surface runoff
b, revision
e, may include surface runoff 
Table 3. Low-flow characteristics for low-flow partial-record stations on Tutuila, American Samoa--Continued

\section{Leafu Stream near Leone.}

Location.--Lat $14^{\circ} 19^{\prime} 47^{\prime \prime S ., ~ l o n g ~} 170^{\circ} 46^{\prime} 55^{\prime \prime W}$, , 30 ft upstream from reservoir, 0.9 mile upstream from mouth, and $1.0 \mathrm{mile}$ north of Leone.

Drainage area. $-0.69 \mathrm{mi}^{2} \quad$ Tributary to.--Pacific Ocean

Type of site.--Low-flow partial-record station.

Period of record.--1959-64, 1968-69, 1971-74, 1976-78, 1981-90.

\begin{tabular}{lcc}
\hline $\begin{array}{l}\text { Streamflow } \\
\text { characteristic }\end{array}$ & $\begin{array}{c}\text { Discharge } \\
\mathrm{ft}^{3} / \mathrm{s}\end{array}$ & $\begin{array}{c}\text { Accuracy } \\
\text { \%SE }\end{array}$ \\
\hline 7-day, 2-year low & 0.88 & 11.6 \\
7-day, 10-year low & 0.38 & 15.4 \\
Mean & 4.55 & 18.7 \\
Median & 2.61 & 12.9 \\
\hline
\end{tabular}

Basis of estimate.--Moments approach with stations 16920500 and 16931000 .

List of measurements: total of 36 .

\begin{tabular}{|c|c|c|c|}
\hline Date & Discharge $\left(\mathrm{ft}^{3} / \mathrm{s}\right)$ & Date & Discharge $\left(\mathrm{ft}^{3} / \mathrm{s}\right)$ \\
\hline $11-05-58$ & 2.77 & $02-15-77$ & $\mathrm{~b} 1.56$ \\
\hline $08-04-59$ & 3.16 & $07-13-77$ & c3. 59 \\
\hline $09-24-60$ & $\mathrm{~b} 1.40$ & $08-19-77$ & 0.74 \\
\hline $10-03-60$ & 1.05 & $07-12-78$ & C1.06 \\
\hline $09-27-61$ & 0.96 & $07-19-78$ & C1.02 \\
\hline $10-02-61$ & be2.13 & $08-03-81$ & $\mathrm{~b} 4.01$ \\
\hline $02-13-63$ & be 4.00 & $10-01-81$ & $\mathrm{~b} 1.64$ \\
\hline $02-20-63$ & 3.98 & $04-20-82$ & 1.29 \\
\hline $05-13-64$ & $\mathrm{~b} 1.88$ & $07-14-83$ & 0.69 \\
\hline $05-09-68$ & b4 .45 & $08-09-83$ & 0.46 \\
\hline $05-24-69$ & b3. 56 & $08-21-84$ & 0.56 \\
\hline $08-05-71$ & $\mathrm{~b} 1.26$ & $08-09-85$ & 0.70 \\
\hline $10-12-71$ & 0.90 & $09-24-86$ & 1.49 \\
\hline $12-15-72$ & 1.30 & $06-02-87$ & 0.53 \\
\hline $07-17-74$ & 1.70 & $09-02-87$ & 1.13 \\
\hline $08-22-74$ & 0.49 & $09-28-88$ & 0.88 \\
\hline $09-22-76$ & 0.84 & $08-15-89$ & 0.55 \\
\hline $09-22-76$ & 0.94 & $08-07-90$ & 0.84 \\
\hline
\end{tabular}


Table 3. Low-flow characteristics for low-flow partial-record stations on Tutuila, American Samoa--Continued

\section{Fuafua stream at Malaeloa.}

Location.--Lat $14^{\circ} 19^{\prime} 58^{\prime \prime S}$., long $170^{\circ} 46^{\prime} 12^{\prime \prime} \mathrm{W} ., 40$ ft downstream from unnamed tributary, $0.8 \mathrm{mile}$ north of Malaeloa, and $2.1 \mathrm{miles}$ upstream from mouth.

Drainage area.--0.29 $\mathrm{mi}^{2} \quad$ Tributary to.--Pacific Ocean.

Type of site.--Low-flow partial-record station.

Period of record.--1959-61, 1963-65, 1971, 1973-74, 1976.

\begin{tabular}{lcc}
\hline $\begin{array}{l}\text { Streamflow } \\
\text { characteristic }\end{array}$ & $\begin{array}{c}\text { Discharge } \\
\mathrm{ft}^{3} / \mathrm{S}\end{array}$ & $\begin{array}{c}\text { Accuracy } \\
\% \mathrm{SE}\end{array}$ \\
\hline 7-day, 2-year low & 0.17 & 20.6 \\
7-day, 10-year low & 0.06 & 31.4 \\
Mean & 1.20 & 30.1 \\
Median & 0.79 & 23.0 \\
\hline
\end{tabular}

Basis of estimate.--Moments approach with station 16920500 .

Remarks.--Lower section of Fuafua Stream called Vailepa stream.

List of measurements: total of 14 .

\begin{tabular}{cr} 
Date & Discharge $\left(\mathrm{ft}^{3} / \mathrm{s}\right)$ \\
\hline $07-23-59$ & 0.50 \\
$08-05-59$ & 0.53 \\
$08-13-59$ & $\mathrm{~b} 0.37$ \\
$09-24-60$ & 0.28 \\
$10-03-60$ & $\mathrm{~b} 0.24$ \\
$09-27-61$ & 0.22 \\
$02-13-63$ & 0.79
\end{tabular}

\begin{tabular}{cr} 
Date & Discharge $\left(\mathrm{ft}^{3} / \mathrm{s}\right)$ \\
\hline $02-20-63$ & $\mathrm{e} 1.08$ \\
$05-14-64$ & $\mathrm{~b} 0.69$ \\
$06-17-65$ & $\mathrm{ab} 2.84$ \\
$07-15-71$ & 0.21 \\
$12-15-72$ & 0.23 \\
$07-17-74$ & 0.21 \\
$09-22-76$ & 0.06
\end{tabular}
a, includes surface runoff
b, revision
e, may include surface runoff 
Table 3. Low-flow characteristics for low-flow partial-record stations on Tutuila, American Samoa--Continued

\section{Sigaloa Stream at Malaeloa.}

Location.--Lat $14^{\circ} 20^{\prime} 27^{\prime \prime S ., ~ l o n g ~} 170^{\circ} 45^{\prime} 53^{\prime \prime} \mathrm{W} ., 0.1$ mile upstream from mouth and 0.3 mile northeast of Malaeloa.

Drainage area.--0.01 $\mathrm{mi}^{2} \quad$ Tributary to.--Vaitai stream.

Type of site.--Low-flow partial-record station.

Period of record. --1959-61, 1963-65, 1968 .

\begin{tabular}{lcc}
\hline Streamflow & $\begin{array}{c}\text { Discharge } \\
\mathrm{ft}^{3} / \mathrm{s}\end{array}$ & $\begin{array}{c}\text { Accuracy } \\
\text { chesE }\end{array}$ \\
\hline 7-day, 2-year low & 0.01 & 25.2 \\
7-day, 10-year low & $<0.01$ & 34.2 \\
Mean & 0.05 & 25.8 \\
Median & 0.03 & 16.6 \\
\hline
\end{tabular}

Basis of estimate.--Moments approach with station 16931000 .

List of measurements: total of 11 .

\begin{tabular}{|c|c|c|c|}
\hline Date & Discharge $\left(\mathrm{ft}^{3} / \mathrm{s}\right)$ & Date & Discharge $\left(\mathrm{ft}^{3} / \mathrm{s}\right)$ \\
\hline $07-23-59$ & 0.01 & $02-13-63$ & b0.02 \\
\hline $08-05-59$ & 0.02 & $02-20-63$ & b0. 02 \\
\hline $08-13-59$ & 0.01 & $05-13-64$ & b0. 04 \\
\hline $09-24-60$ & 0.02 & $06-17-65$ & 0.09 \\
\hline $10-03-60$ & b0.01 & $05-07-68$ & 0.06 \\
\hline $09-27-61$ & 0.02 & & \\
\hline
\end{tabular}


Table 3. Low-flow characteristics for low-flow partial-record stations on Tutuila, American Samoa--Continued

\section{Leaveave Stream at Mapusagafou.}

Location.--Lat $14^{\circ} 19^{\prime} 12^{\prime \prime} \mathrm{S} .$, long $170^{\circ} 45^{\prime} 00^{\prime \prime} \mathrm{W} ., 0.1$ mile upstream from Puna Stream and $0.7 \mathrm{mile}$ north of Mapusagafou.

Drainage area.--0.15 $\mathrm{mi}^{2} \quad$ Tributary to. $--\mathrm{N} / \mathrm{A}$.

Type of site.--Low-flow partial-record station.

period of record.--1959-65, 1968, 1971, 1974, 1976.

\begin{tabular}{lcc}
\hline Streamflow & $\begin{array}{c}\text { Discharge } \\
\text { characteristic }\end{array}$ & $\begin{array}{c}\text { Accuracy } \\
\mathrm{ft} / \mathrm{SE}\end{array}$ \\
\hline 7-day, 2-year low & 0.11 & 18.5 \\
7-day, 10-year low & 0.05 & 25.8 \\
Mean & 0.47 & 17.0 \\
Median & 0.33 & 13.7 \\
\hline
\end{tabular}

Basis of estimate.--Moments approach with station 16920500 .

List of measurements: total of 15 .

\begin{tabular}{|c|c|c|c|}
\hline Date & Discharge $\left(\mathrm{ft}^{3} / \mathrm{s}\right)$ & Date & Discharge $\left(\mathrm{ft}^{3} / \mathrm{s}\right)$ \\
\hline $07-24-59$ & 0.37 & $02-20-63$ & be 0.55 \\
\hline $08-06-59$ & 0.24 & $05-14-64$ & b0. 30 \\
\hline $08-12-59$ & 0.17 & $06-18-65$ & 0.62 \\
\hline $09-24-60$ & b0 .10 & $05-07-68$ & 0.57 \\
\hline $10-03-60$ & 0.08 & $03-08-71$ & 0.36 \\
\hline $09-26-61$ & 0.11 & $07-17-74$ & 0.16 \\
\hline $10-02-61$ & 0.17 & $10-29-75$ & 0.08 \\
\hline $02-14-63$ & $\mathrm{e} 0.31$ & & \\
\hline
\end{tabular}

b, revision

e, may include surface runoff 
Table 3. Low-flow characteristics for low-flow partial-record stations on Tutuila, American Samoa--Continued

$$
16937000 \text { Vaitele stream at Lepine. }
$$

Location.--Lat $14^{\circ} 18^{\prime} 51^{\prime \prime S .,}$ long $170^{\circ} 43^{\prime} 35^{\prime \prime} \mathrm{W} ., 0.7$ mile north of Lepine and 1.1 miles upstream from mouth.

Drainage area. $--0.18 \mathrm{mi}^{2}$.

Tributary to.--Pacific Ocean.

Type of site.--Low-flow partial-record station.

Period of record.--1959-61, 1963-65, 1967-69, 1971, 1974, 1976, 1989.

\begin{tabular}{lcc}
\hline $\begin{array}{l}\text { Streamflow } \\
\text { characteristic }\end{array}$ & $\begin{array}{c}\text { Discharge } \\
\mathrm{ft} \text { / } / \mathrm{s}\end{array}$ & $\begin{array}{c}\text { Accuracy } \\
\text { \%SE }\end{array}$ \\
\hline 7-day, 2-year low & 0.32 & 10.3 \\
7-day, 10-year low & 0.18 & 21.3 \\
Mean & 0.85 & 12.0 \\
Median & 0.67 & 10.0 \\
\hline
\end{tabular}

Basis of estimate.--Moments approach with station 16920500 .

List of measurements: total of 19 .

\begin{tabular}{cccc} 
Date & Discharge $\left(\mathrm{ft}^{3} / \mathrm{s}\right)$ & Date & Discharge $\left(\mathrm{ft}^{3} / \mathrm{s}\right)$ \\
\cline { 2 - 2 } $10-18-58$ & 1.14 & $05-18-64$ & $\mathrm{a} 2.03$ \\
$08-04-59$ & 0.85 & $06-23-65$ & $\mathrm{ab2} .76$ \\
$08-13-59$ & 0.42 & $05-24-67$ & $\mathrm{~b} 1.01$ \\
$09-23-60$ & $\mathrm{~b} 0.35$ & $05-03-68$ & 0.71 \\
$10-03-60$ & 0.28 & $05-22-69$ & 0.86 \\
$09-22-61$ & 0.28 & $07-28-71$ & 0.33 \\
$09-29-61$ & 0.25 & $07-17-74$ & 0.39 \\
$02-11-63$ & 0.68 & $10-29-75$ & 0.23 \\
$02-21-63$ & 0.51 & $09-28-89$ & 0.22 \\
$05-11-64$ & $\mathrm{~b} 0.97$ & &
\end{tabular}

a, includes surface runoff

b, revision 
Table 3. Low-flow characteristics for low-flow partial-record stations on Tutuila, American Samoa--Continued

\section{Vaitele Stream tributary at Lepine.}

Location.--Lat $14^{\circ} 18^{\prime} 57^{\prime S} \mathrm{~S} ., 170^{\circ} 43^{\prime} 21^{\prime \prime W}$., 0.2 mile upstream from mouth and 0.7 mile northeast of Lepine.

Drainage area.--0.09 $\mathrm{mi}^{2} \quad$ Tributary to.--Vaitele Stream.

Type of site.--Low-flow partial-record station.

Period of record.--1959-61, 1963-65, 1967-69, 1974, 1976.

\begin{tabular}{lcc}
\hline $\begin{array}{l}\text { Streamflow } \\
\text { characteristic }\end{array}$ & $\begin{array}{c}\text { Discharge } \\
\mathrm{ft}^{3} / \mathrm{s}\end{array}$ & $\begin{array}{c}\text { Accuracy } \\
\text { \%SE }\end{array}$ \\
\hline 7-day, 2-year low & 0.11 & 20.1 \\
7-day, 10-year low & 0.05 & 26.2 \\
Mean & 0.55 & 20.2 \\
Median & 0.26 & 12.5 \\
\hline
\end{tabular}

Basis of estimate.--Moments approach with station 16948000 .

List of measurements: total of 17 .

\begin{tabular}{|c|c|c|c|}
\hline Date & Discharge $\left(\mathrm{ft}^{3} / \mathrm{s}\right)$ & Date & Discharge $\left(\mathrm{ft}^{3} / \mathrm{s}\right)$ \\
\hline $10-18-58$ & 0.39 & $05-16-64$ & 0.25 \\
\hline $08-04-59$ & 0.28 & $05-18-64$ & $\mathrm{ab} 0.47$ \\
\hline $08-13-59$ & 0.16 & $06-23-65$ & a 0.82 \\
\hline $09-23-60$ & 0.22 & $05-24-67$ & 0.46 \\
\hline $10-03-60$ & 0.16 & $05-03-68$ & $\mathrm{f} 0.67$ \\
\hline $09-22-61$ & b0. 18 & $05-22-69$ & 0.53 \\
\hline $09-29-61$ & $\mathrm{~b} 0.16$ & $07-17-74$ & 0.11 \\
\hline $02-11-63$ & 0.29 & $09-27-76$ & 0.05 \\
\hline $02-21-63$ & b0. 21 & & \\
\hline
\end{tabular}
a, includes surface runoff
b, revision
$\mathrm{f}$, surface runoff at index station on this date 
Table 3. Low-flow characteristics for low-flow partial-record stations on Tutuila, American Samoa--Continued

\section{Taumata Stream near Mapusaga.}

Location.--Lat. $14^{\circ} 18^{\prime} 23^{\prime \prime S ., ~ l o n g ~} 170^{\circ} 44^{\prime} 00^{\prime \prime W} ., 100$ ft upstream from unnamed tributary, 1.6 miles north of Mapusaga, and 2.2 miles upstream from mouth.

Drainage area.--0.02 $\mathrm{mi}^{2} \quad$ Tributary to.--Vaitele stream

Type of site.--Low-flow partial-record station.

Period of record.--1959-61, 1963-65, 1968-69, 1974.

\begin{tabular}{lcc}
\hline Streamflow & $\begin{array}{c}\text { Discharge } \\
\mathrm{ft}^{3} / \mathrm{s}\end{array}$ & $\begin{array}{c}\text { Accuracy } \\
\text { characteristic }\end{array}$ \\
\hline 7-day, 2-year low & 0.06 & 10.8 \\
7-day, 10-year low & 0.03 & 19.6 \\
Mean & 0.20 & 12.9 \\
Median & 0.12 & 9.3 \\
\hline
\end{tabular}

Basis of estimate.--Moments approach with station 16931000 .

Remarks.--Measurements from 1959 to 1965 were previously published in error as belonging to station 16940000. Stream goes dry at lower elevations.

List of measurements: total of 14 .

\begin{tabular}{|c|c|c|c|}
\hline Date & Discharge $\left(\mathrm{ft}^{3} / \mathrm{s}\right)$ & Date & Discharge $\left(\mathrm{ft}^{3} / \mathrm{s}\right)$ \\
\hline$\overline{07-24-59}$ & 0.07 & $02-12-63$ & $\mathrm{~b} 0.17$ \\
\hline $08-06-59$ & 0.08 & $02-19-63$ & 0.12 \\
\hline $08-13-59$ & 0.06 & $05-15-64$ & 0.10 \\
\hline $09-23-60$ & 0.12 & $06-18-65$ & $\mathrm{~b} 0.25$ \\
\hline $10-03-60$ & 0.12 & $05-09-68$ & 0.19 \\
\hline $09-22-61$ & 0.06 & $05-27-69$ & 0.09 \\
\hline $09-29-61$ & 0.07 & $09-04-74$ & 0.03 \\
\hline
\end{tabular}

b, revision 
Table 3. Low-flow characteristics for low-flow partial-record stations on Tutuila, American Samoa--Continued

\section{Taumata Stream tributary near Mapusaga.}

Location.--Lat $14^{\circ} 18^{\prime} 27^{\prime \prime} \mathrm{S} .$, long $170^{\circ} 43^{\prime} 49^{\prime \prime} \mathrm{W} ., 0.5 \mathrm{mile}$ upstream from mouth and 1.6 miles northeast of Mapusaga.

Drainage area. $--0.04 \mathrm{mi}^{2} \quad$ Tributary to.--Taumata stream

Type of site.--Low-flow partial-record station.

Period of record.--1959-61, 1963-65, 1969, 1974.

\begin{tabular}{lcc}
\hline $\begin{array}{l}\text { Streamflow } \\
\text { characteristic }\end{array}$ & $\begin{array}{c}\text { Discharge } \\
\mathrm{ft}^{3} / \mathrm{s}\end{array}$ & $\begin{array}{c}\text { Accuracy } \\
\text { \%SE }\end{array}$ \\
\hline 7-day, 2-year low & 0.09 & 24.8 \\
7-day, 10-year low & 0.02 & 45.0 \\
Mean & 0.30 & 26.6 \\
Median & 0.22 & 20.8 \\
\hline
\end{tabular}

Basis of estimate.--Graphical correlation with station 16931000 .

Remarks.--Measurements from 1959 to 1965 were previously published in error as belonging to station 16939000 .

List of measurements: total of 13 .

\begin{tabular}{|c|c|c|c|}
\hline Date & Discharge $\left(\mathrm{ft}^{3} / \mathrm{s}\right)$ & Date & Discharge $\left(\mathrm{ft}^{3} / \mathrm{s}\right)$ \\
\hline $07-24-59$ & 0.13 & $02-12-63$ & $\mathrm{~b} 0.27$ \\
\hline $08-06-59$ & 0.17 & $02-19-63$ & 0.12 \\
\hline $08-13-59$ & 0.12 & $05-15-64$ & 0.20 \\
\hline $09-23-60$ & 0.23 & $06-18-65$ & b0 0.55 \\
\hline $10-03-60$ & 0.17 & $05-27-69$ & $\mathrm{c} 0.25$ \\
\hline $09-22-61$ & 0.14 & $09-04-74$ & C 0 \\
\hline $09-29-61$ & 0.11 & & \\
\hline
\end{tabular}


Table 3. Low-flow characteristics for low-flow partial-record stations on Tutuila, American Samoa--Continued

\section{Mapusagatuai stream at Mapusaga.}

Location.--Lat $14^{\circ} 19^{\prime} 38^{\prime \prime} \mathrm{S} .$, long $170^{\circ} 44^{\prime} 48^{\prime \prime} \mathrm{W} ., 0.3 \mathrm{mile}$ west of Mapusaga and 1.2 mile upstream from mouth.

Drainage area. $-0.08 \mathrm{mi}^{2} \quad$ Tributary to.--Taumata stream

Type of site.--Low-flow partia1-record station.

Period of record.--1959-61, 1963-65, 1968-70, 1974, 1976.

\begin{tabular}{lcc}
\hline $\begin{array}{l}\text { Streamflow } \\
\text { characteristic }\end{array}$ & $\begin{array}{c}\text { Discharge } \\
\mathrm{ft}^{3} / \mathrm{S}\end{array}$ & $\begin{array}{c}\text { Accuracy } \\
\mathrm{8SE}\end{array}$ \\
\hline 7-day, 2-year low & 0.11 & 15.5 \\
7-day, 10-year low & 0.05 & 21.5 \\
Mean & 0.29 & 21.5 \\
Median & 0.23 & 16.7 \\
\hline
\end{tabular}

Basis of estimate.--Moments approach with station 16920500 .

Remarks. --Stream goes dry downstream from station because of diversion by village.

List of measurements: total of 16 .

\begin{tabular}{cc} 
Date & Discharge $\left(\mathrm{ft}^{3} / \mathrm{s}\right)$ \\
\hline $07-24-59$ & 0.14 \\
$08-06-59$ & 0.12 \\
$09-23-60$ & $\mathrm{~b} 0.18$ \\
$10-01-60$ & 0.17 \\
$09-25-61$ & 0.10 \\
$09-29-61$ & 0.09 \\
$02-12-63$ & $\mathrm{~b} 0.13$ \\
$02-20-63$ & 0.26
\end{tabular}

\begin{tabular}{cr} 
Date & Discharge $\left(\mathrm{ft}^{3} / \mathrm{s}\right)$ \\
\hline $05-14-64$ & $\mathrm{~b} 0.27$ \\
$05-18-64$ & $\mathrm{f} 0.32$ \\
$06-17-65$ & 0.56 \\
$05-07-68$ & 0.30 \\
$05-26-69$ & 0.25 \\
$09-17-70$ & $\mathrm{f} 0.20$ \\
$07-17-74$ & 0.15 \\
$10-29-75$ & 0.04
\end{tabular}

b, revision

$f$, surface runoff at index station on this date 
Table 3. Low-flow characteristics for low-flow partial-record stations on Tutuila, American Samoa--Continued

\section{Sauino stream near Nuuuli.}

Location.--Lat $14^{\circ} 18^{\prime} 53^{\prime \prime S ., ~ l o n g ~} 170^{\circ} 43^{\prime} 03^{\prime \prime} \mathrm{W} ., 0.6$ mile upstream from mouth and 1.3 miles west of Nuuuli.

Drainage area.--0.09 $\mathrm{mi}^{2}$. Tributary to.--Pacific Ocean

Type of site.--Low-flow partial-record station.

Period of record.--1959-61, 1963-65, 1968-69, 1971, 1974-75.

\begin{tabular}{lcc}
\hline $\begin{array}{l}\text { Streamflow } \\
\text { characteristic }\end{array}$ & $\begin{array}{c}\text { Discharge } \\
\mathrm{ft}^{3} / \mathrm{s}\end{array}$ & $\begin{array}{c}\text { Accuracy } \\
\text { \%SE }\end{array}$ \\
\hline 7-day, 2-year low & 0.10 & 12.7 \\
7-day, 10-year low & 0.05 & 24.6 \\
Mean & 0.37 & 15.8 \\
Median & 0.25 & 11.8 \\
\hline
\end{tabular}

Basis of estimate.--Moments approach with stations 16920500 and 16948000 .

List of measurements: total of 17 .

\begin{tabular}{lccc} 
Date & Discharge $\left(\mathrm{ft}^{3} / \mathrm{s}\right)$ & Date & Discharge $\left(\mathrm{ft}^{3} / \mathrm{s}\right)$ \\
\cline { 2 - 3 } $07-23-59$ & 0.14 & $05-16-64$ & $\mathrm{~b} 0.24$ \\
$08-06-59$ & 0.16 & $05-22-64$ & 0.48 \\
$08-13-59$ & 0.14 & $06-24-65$ & $\mathrm{be} 0.58$ \\
$09-23-60$ & 0.20 & $05-03-68$ & 0.37 \\
$10-03-60$ & $\mathrm{~b} 0.15$ & $05-22-69$ & 0.42 \\
$09-22-61$ & 0.08 & $10-01-70$ & 0.21 \\
$09-30-61$ & 0.09 & $07-22-74$ & 0.14 \\
$02-09-63$ & 0.19 & $09-25-75$ & 0.08 \\
$02-21-63$ & 0.17 & & \\
b. revision & & & \\
e, may include surface runoff & &
\end{tabular}


Table 3. Low-flow characteristics for low-flow partial-record stations on Tutuila, American Samoa--Continued

\section{Mataalii Stream near Nuuuli.}

Location.--Lat $14^{\circ} 18^{\prime} 42^{\prime \prime S} .$, long $170^{\circ} 42^{\prime} 51^{\prime \prime} \mathrm{W} ., 0.6$ mile upstream from mouth and 1.1 miles northwest of Nuuuli.

Drainage area.--0.14 $\mathrm{mi}^{2}$. Tributary to.--Pacific Ocean.

Type of site.--Low-flow partial-record station.

Period of record.--1959-61, 1963-65, 1968-69, 1974-76.

\begin{tabular}{lcc}
\hline $\begin{array}{l}\text { Streamflow } \\
\text { characteristic }\end{array}$ & $\begin{array}{c}\text { Discharge } \\
\mathrm{ft}^{3} / \mathrm{s}\end{array}$ & $\begin{array}{c}\text { Accuracy } \\
\mathrm{oSE}\end{array}$ \\
\hline 7-day, 2-year low & 0.31 & 15.7 \\
7-day, 10-year low & 0.15 & 20.8 \\
Mean & 0.98 & 20.0 \\
Median & 0.60 & 13.1 \\
\hline
\end{tabular}

Basis of estimate.--Moments approach with station 16931000 .

List of measurements: total of 17 .

\begin{tabular}{|c|c|c|c|}
\hline Date & Discharge $\left(\mathrm{ft}^{3} / \mathrm{s}\right)$ & Date & Discharge $\left(\mathrm{ft}^{3} / \mathrm{s}\right)$ \\
\hline $07-24-59$ & 0.52 & $\overline{05-16-64}$ & 0.53 \\
\hline $08-06-59$ & 0.57 & $05-22-64$ & e1.21 \\
\hline $08-13-59$ & 0.47 & $06-24-65$ & be 1.15 \\
\hline $09-22-60$ & 0.56 & $05-03-68$ & 0.73 \\
\hline $09-30-60$ & 0.46 & $05-27-69$ & 0.45 \\
\hline $09-25-61$ & $\mathrm{~b} 0.47$ & $07-22-74$ & 0.14 \\
\hline $09-30-61$ & 0.39 & $09-25-75$ & 0.20 \\
\hline $02-09-63$ & 0.60 & $09-14-76$ & 0.15 \\
\hline $02-22-63$ & b0. 61 & & \\
\hline
\end{tabular}

b, revision

e, may include surface runoff 
Table 3. Low-flow characteristics for low-flow partial-record stations on Tutuila, American Samoa--Continued

\section{Papa Stream near Nuuuli.}

Location.--Lat $14^{\circ} 18^{\prime} 31^{\mathrm{MS}}$., long $170^{\circ} 42^{\prime} 29^{\prime \prime} \mathrm{W} ., 0.3$ mile upstream from Tauese stream and 0.9 mile northwest of Nuuli.

Drainage area.--0.57 $\mathrm{mi}^{2} \quad$ Tributary to.--Pacific Ocean

Type of site.--Low-flow partial-record station.

Period of record.--1959-61, 1963-64, 1967-68, 1974-76, 1983-90.

\begin{tabular}{lcc}
\hline $\begin{array}{l}\text { Streamflow } \\
\text { characteristic }\end{array}$ & $\begin{array}{c}\text { Discharge } \\
\mathrm{ft}^{3} / \mathrm{s}\end{array}$ & $\begin{array}{c}\text { Accuracy } \\
\frac{\mathrm{oSE}}{8}\end{array}$ \\
\hline 7-day, 2-year low & 0.54 & 14.5 \\
7-day, 10-year low & 0.21 & 21.3 \\
Mean & 2.83 & 28.4 \\
Median & 1.48 & 19.5 \\
\hline
\end{tabular}

Basis of estimate.--Moments approach with stations 16920500 and 16948000 .

Remarks.--Stream was observed dry below station in October 1974 .

List of measurements: total of 30 .

\begin{tabular}{cr} 
Date & Discharge $\left(\mathrm{ft}^{3} / \mathrm{s}\right)$ \\
\hline $07-28-59$ & 1.11 \\
$08-05-59$ & 1.90 \\
$08-12-59$ & 1.16 \\
$09-22-60$ & 1.04 \\
$09-30-60$ & 0.76 \\
$09-25-61$ & $\mathrm{~b} 0.75$ \\
$09-30-61$ & 0.59 \\
$02-09-63$ & 1.19 \\
$02-22-63$ & 1.59 \\
$05-16-63$ & $\mathrm{c} 1.94$ \\
$05-16-64$ & $\mathrm{~b} 1.43$ \\
$05-22-64$ & $\mathrm{a} 4.02$ \\
$05-24-67$ & $\mathrm{a} 3.19$ \\
$05-03-68$ & 2.09 \\
$08-19-74$ & 0.18
\end{tabular}

\begin{tabular}{cc} 
Date & Discharge $\left(\mathrm{ft}^{3} / \mathrm{s}\right)$ \\
\hline $04-03-75$ & $\mathrm{a} 9.71$ \\
$09-26-75$ & 0.74 \\
$09-14-76$ & 0.74 \\
$09-14-83$ & 0.20 \\
$08-21-84$ & 0.07 \\
$07-23-85$ & 1.11 \\
$09-06-85$ & 0.85 \\
$08-06-86$ & 0.90 \\
$09-05-86$ & 0.42 \\
$06-02-87$ & 0.69 \\
$09-17-87$ & 0.70 \\
$09-27-88$ & 0.69 \\
$07-19-89$ & 0.97 \\
$09-21-89$ & 0.67 \\
$08-30-90$ & 0.58
\end{tabular}
a, includes surface runoff
b, revision
c, not previously published 
Table 3. Low-flow characteristics for low-flow partial-record stations on Tutuila, American Samoa--Continued

\section{Amaile Stream at Nuuuli.}

Location.--Lat $14^{\circ} 18^{\prime} 43^{\prime \prime S ., ~ l o n g ~} 170^{\circ} 41^{\prime} 48^{\prime \prime} \mathrm{W} ., 0.3$ mile upstream from mouth and 0.5 mile north of Nuuuli.

Drainage area.--0.19 $\mathrm{mi}^{2} \quad$ Tributary to.--Pacific Ocean

Type of site.--Low-flow partial-record station.

Period of record.--1959-61, 1963-64, 1968-69, 1974-76.

\begin{tabular}{lcc}
\hline $\begin{array}{l}\text { Streamflow } \\
\text { characteristic }\end{array}$ & $\begin{array}{c}\text { Discharge } \\
\mathrm{ft}^{3} / \mathrm{s}\end{array}$ & $\begin{array}{c}\text { Accuracy } \\
\text { \%SE }\end{array}$ \\
\hline 7-day, 2-year low & 0.11 & 24.7 \\
7-day, 10-year low & 0.04 & 35.1 \\
Mean & 1.30 & 44.0 \\
Median & 0.45 & 24.1 \\
\hline
\end{tabular}

Basis of estimate.--Moments approach with 16912000 .

List of measurements: total of 14 .

\begin{tabular}{|c|c|c|c|}
\hline Date & Discharge $\left( \pm t^{3} / s\right)$ & Date & Discharge $\left(\mathrm{ft}^{3} / \mathrm{s}\right)$ \\
\hline$\overline{07-23-59}$ & 0.21 & $\overline{02-19-63}$ & $\mathrm{~b} 0.44$ \\
\hline $08-05-59$ & 0.24 & $05-16-64$ & $\mathrm{~b} 0.61$ \\
\hline $09-22-60$ & b0 .39 & $05-02-68$ & 0.73 \\
\hline $09-30-60$ & b0. 38 & $05-26-69$ & 0.37 \\
\hline $09-26-61$ & 0.22 & $07-22-74$ & 0.07 \\
\hline $09-29-61$ & $\mathrm{bo} 0.16$ & $09-29-75$ & 0.08 \\
\hline $02-09-63$ & 0.42 & $09-14-76$ & 0.04 \\
\hline
\end{tabular}


Table 3. Low-flow characteristics for low-flow partial-record stations on Tutuila, American Samoa--Continued

\section{Avau Stream at Faganeanea.}

Location.--Lat $14^{\circ} 18 \cdot 34^{\mathrm{NS} .}$, long $170^{\circ} 41 \cdot 35^{\prime \prime} \mathrm{W} ., 0.2$ mile upstream from mouth and 0.4 mile southwest of Faganeanea.

Drainage area.--0.09 $\mathrm{mi}^{2} \quad$ Tributary to.--Pacific Ocean

Type of site.--Low-flow partial-record station.

Period of record.--1959-61, 1963-65, 1967-69, 1974-76.

\begin{tabular}{lcc}
\hline $\begin{array}{l}\text { Streamflow } \\
\text { characteristic }\end{array}$ & $\begin{array}{c}\text { Discharge } \\
\mathrm{ft}^{3} / \mathrm{s}\end{array}$ & $\begin{array}{c}\text { Accuracy } \\
\text { \%SE }\end{array}$ \\
\hline 7-day, 2-year low & 0.10 & 12.2 \\
7-day, 10-year low & 0.05 & 16.7 \\
Mean & 0.40 & 14.4 \\
Median & 0.23 & 10.3 \\
\hline
\end{tabular}

Basis of estimate.--Moments approach with station 16931000 .

List of measurements: total of 18 .

\begin{tabular}{cccc} 
Date & Discharge $\left(\mathrm{ft}^{3} / \mathrm{s}\right)$ & Date & Discharge $\left(\mathrm{ft}^{3} / \mathrm{s}\right)$ \\
\cline { 1 - 2 } $07-23-59$ & 0.08 & $05-22-64$ & 0.42 \\
$08-04-59$ & 0.12 & $06-16-65$ & 0.53 \\
$09-22-60$ & 0.12 & $05-29-67$ & 0.36 \\
$09-30-60$ & 0.17 & $05-02-68$ & 0.40 \\
$09-26-61$ & 0.12 & $05-22-69$ & 0.25 \\
$09-29-61$ & 0.12 & $07-22-74$ & 0.12 \\
$02-09-63$ & $\mathrm{~b} 0.24$ & $09-23-74$ & 0.08 \\
$02-22-63$ & $\mathrm{~b} 0.18$ & $09-29-75$ & 0.08 \\
$05-16-64$ & 0.28 & $09-14-76$ & 0.10
\end{tabular}

b, revision 
Table 3. Low-flow characteristics for low-flow partial-record stations on Tutuila, American Samoa--Continued

16947000 Afu Stream at Faganeanea.

Location.--Lat $14^{\circ} 18^{\prime} 16^{\prime \prime} \mathrm{S} .$, long $170^{\circ} 41^{\prime} 25^{\prime \prime} \mathrm{W} ., 0.2$ mile northwest of Faganeanea and 0.3 mile upstream from mouth.

Drainage area.--0.22 $\mathrm{mi}^{2} \quad$ Tributary to.--Pacific Ocean.

Type of site.--Low-flow partial-record station.

Period of record.--1959-61, 1963-65, 1967-69, 1971, 1974-76.

\begin{tabular}{lcc}
\hline Streamflow & $\begin{array}{c}\text { Discharge } \\
\text { characteristic }\end{array}$ & $\begin{array}{c}\text { Accuracy } \\
\text { o } / \mathrm{sE}\end{array}$ \\
\hline 7-day, 2-year low & 0.03 & 24.0 \\
7-day, 10-year low & 0.01 & 33.7 \\
Mean & 0.58 & 39.3 \\
Median & 0.17 & 23.2 \\
\hline
\end{tabular}

Basis of estimate.--Moments approach with station 16912000 .

Iist of measurements: total of 20 .

\begin{tabular}{|c|c|c|c|}
\hline Date & Discharge $\left(\mathrm{ft}^{3} / \mathrm{s}\right)$ & Date & Discharge $\left(\mathrm{ft}^{3} / \mathrm{s}\right)$ \\
\hline $10-18-58$ & 0.46 & $05-22-64$ & a1. 45 \\
\hline $07-30-59$ & 0.09 & $06-14-65$ & a1. 64 \\
\hline $08-13-59$ & 0.08 & $05-29-67$ & 0.32 \\
\hline $09-22-60$ & 0.06 & $05-02-68$ & 0.39 \\
\hline $09-30-60$ & $\mathrm{~b} 0.04$ & $05-22-69$ & 0.20 \\
\hline $09-26-61$ & b0.04 & $10-01-70$ & 0.27 \\
\hline $09-29-61$ & 0.02 & $07-22-74$ & 0.07 \\
\hline $02-09-63$ & 0.12 & $09-23-74$ & 0.03 \\
\hline $02-22-63$ & b0. 18 & $09-25-75$ & 0.05 \\
\hline $05-16-64$ & $\mathrm{~b} 0.15$ & $09-14-76$ & 0.01 \\
\hline
\end{tabular}
a, includes surface runoff
b, revision 
Table 3. Low-flow characteristics for low-flow partial-record stations on Tutuila, American Samoa--Continued

\section{Matafao stream at Fagaalu.}

Location.--Lat $14^{\circ} 17^{\prime} 34^{\prime \prime S .,}$ long $170^{\circ} 41 \cdot 43^{\prime \prime W} ., 100$ ft upstream from Vaitanoa Pool and 0.9 mile west of Fagaalu.

Drainage area.--0.24 $\mathrm{mi}^{2} \quad$ Tributary to.--Fagaalu stream.

Type of site.--Low-flow partial-record station.

Period of record.--1959, 1961, 1963-64.

\begin{tabular}{lcc}
\hline Streamflow & $\begin{array}{c}\text { Discharge } \\
\mathrm{ft}^{3} / \mathrm{s}\end{array}$ & $\begin{array}{c}\text { Accuracy } \\
\text { characteristic }\end{array}$ \\
\hline 7-day, 2-year low & 0.14 & 18.8 \\
7-day, 10-year low & 0.09 & 30.3 \\
Mean & 1.10 & 18.6 \\
Median & 0.33 & 14.3 \\
\hline
\end{tabular}

Basis of estimate.--Graphical correlation with station 16948000 using pre-diversion values.

Remarks.--Municipal diversion upstream from site.

List of measurements: total of 9 .

\begin{tabular}{|c|c|c|c|}
\hline Date & Discharge $\left(\mathrm{ft}^{3} / \mathrm{s}\right)$ & Date & Discharge $\left(\mathrm{ft}^{3} / \mathrm{s}\right)$ \\
\hline$\overline{07-25-59}$ & 0.22 & $02-13-63$ & $\mathrm{~b} 0.58$ \\
\hline $08-07-59$ & 0.25 & $02-22-63$ & $\mathrm{~b} 0.52$ \\
\hline $10-01-60$ & b0 .15 & $05-13-63$ & $\mathrm{C} 0.58$ \\
\hline $10-04-60$ & 0.20 & $05-23-64$ & 0.62 \\
\hline $09-23-61$ & 0.14 & & \\
\hline
\end{tabular}

b, revision

c, not previously published 
Table 3. Low-flow characteristics for low-flow partial-record stations on Tutuila, American Samoa--Continued

\section{Fagaalu stream at Fagaalu.}

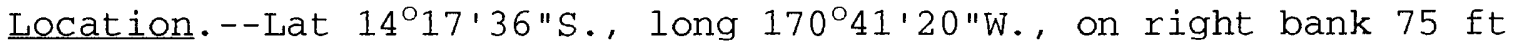
upstream from pipeline intake and 0.5 mile west of Fagaalu (revision).

Drainage area.--0.42 $\mathrm{mi}^{2} \quad$ Tributary to.--Pacific Ocean.

Type of site.--Daily record station.

Period of record.--April 1957 - June 1958, miscellaneous measurement in 1958 and 1963.

Average discharge. - not determined.

Extremes for period of record.--Maximum not determined; minimum 0.43 $\mathrm{ft}^{3} / \mathrm{s}$ on February 1 and $2,1958$.

\begin{tabular}{lcc}
\hline $\begin{array}{l}\text { Streamflow } \\
\text { characteristic }\end{array}$ & $\begin{array}{c}\text { Discharge } \\
\mathrm{ft}^{3} / \mathrm{S}\end{array}$ & $\begin{array}{c}\text { Accuracy } \\
8 \mathrm{SE}\end{array}$ \\
\hline 7-day, 2-year low & 0.13 & 38.5 \\
7-day, 10-year low & 0.08 & 79.1 \\
Mean & 1.10 & 24.6 \\
Median & 0.32 & 16.4 \\
\hline
\end{tabular}

Basis of estimate.--Graphical correlation with station 16948000 using 11 mean daily base-flow discharges from March to June 1958.

Remarks. --Station treated as a low-flow partial-record site. Municipal diversion upstream of site prior to period of record.

List of measurements: total of 2 .

$\frac{\text { Date }}{04-07-58} \quad \frac{\text { Discharge }\left(\mathrm{ft}^{3} / \mathrm{s}\right)}{1.42} \quad \frac{\text { Date }}{05-15-63} \quad \frac{\text { Discharge }\left(\mathrm{ft}^{3} / \mathrm{s}\right)}{0.85}$


Table 3. Low-flow characteristics for low-flow partial-record stations on Tutuila, American Samoa--Continued

\section{Vaima Stream at Pago Pago.}

Location.--Lat $14^{\circ} 17^{\prime} 30^{\prime \prime S ., ~ l o n g ~} 170^{\circ} 42^{\prime} 29^{\prime \prime} \mathrm{W} ., 0.4$ mile upstream from mouth and 1.0 mile southwest from Pago Pago.

Drainage area.--0.05 $\mathrm{mi}^{2} \quad$ Tributary to.--Vaipito Stream

Type of site.--Low-flow partial-record station.

Period of record.--1959-65, 1967-68, 1970, 1975-76.

\begin{tabular}{lcc}
\hline $\begin{array}{l}\text { Streamflow } \\
\text { characteristic }\end{array}$ & $\begin{array}{c}\text { Discharge } \\
\mathrm{ft}^{3} / \mathrm{s}\end{array}$ & $\begin{array}{c}\text { Accuracy } \\
\text { \%SE }\end{array}$ \\
\hline 7-day, 2-year low & 0.06 & 21.1 \\
7-day, 10-year low & 0.02 & 28.1 \\
Mean & 0.35 & 30.2 \\
Median & 0.16 & 19.7 \\
\hline
\end{tabular}

Basis of estimate.--Moments approach with station 16931000 and 16948000 .

List of measurements: total of 20 .

\begin{tabular}{cc} 
Date & Discharge $\left(\mathrm{ft}^{3} / \mathrm{s}\right)$ \\
\hline $07-22-59$ & 0.21 \\
$08-04-59$ & 0.22 \\
$08-12-59$ & 0.11 \\
$09-28-60$ & 0.09 \\
$10-04-60$ & $\mathrm{~b} 0.10$ \\
$09-20-61$ & $\mathrm{~b} 0.10$ \\
$10-02-61$ & $\mathrm{f} 0.50$ \\
$02-04-63$ & 0.12 \\
$02-22-63$ & $\mathrm{~b} 0.13$ \\
$05-11-64$ & 0.16
\end{tabular}

$\begin{array}{cc}\frac{\text { Date }}{06-14-65} & \text { Discharge } \\ \begin{array}{cc}\text { ab } 0.69 \\ 05-29-67\end{array} & 0.09 \\ 04-30-68 & 0.33 \\ 09-13-70 & 0.22 \\ 09-30-70 & 0.24 \\ 05-10-71 & 0.10 \\ 03-12-74 & 0.12 \\ 11-04-74 & 0.01 \\ 09-23-75 & 0.06 \\ 09-23-76 & 0.18\end{array}$
a, includes surface runoff
b, revision
c, not previously published
$f$, surface runoff at index station on this date 
Table 3. Low-flow characteristics for low-flow partial-record stations on Tutuila, American Samoa--Continued

\section{Utumoa Stream near Pago Pago.}

Location.--Lat $14^{\circ} 17 \cdot 35^{\prime \prime S}$., long $170^{\circ} 42^{\prime} 20^{\prime \prime} \mathrm{W} ., 0.6$ mile upstream from mouth and 1.1 miles south of Pago Pago.

Drainage area. $-0.07 \mathrm{mi}^{2}$. Tributary to.--Vaipito stream

Type of site.--Low-flow partial-record station.

Period of record.--1959-61, 1963-65, 1967-71, 1974-75, 1983, 1986-87, 1989.

\begin{tabular}{lcc}
\hline $\begin{array}{l}\text { Streamflow } \\
\text { characteristic }\end{array}$ & $\begin{array}{c}\text { Discharge } \\
\mathrm{ft}^{3} / \mathrm{S}\end{array}$ & $\begin{array}{c}\text { Accuracy } \\
\% \mathrm{SE}\end{array}$ \\
\hline 7-day, 2-year low & 0.23 & 10.4 \\
7-day, 10-year low & 0.14 & 15.3 \\
Mean & 0.65 & 12.4 \\
Median & 0.42 & 8.1 \\
\hline
\end{tabular}

Basis of estimate.--Moments approach with station 16912000 .

Remarks. --Municipal diversion (Vaipito intake) immediately downstream of site.

List of measurements: total of 29 .

\begin{tabular}{cccc} 
Date & Discharge $\left(\mathrm{ft}^{3} / \mathrm{s}\right)$ & Date & Discharge $\left(\mathrm{ft}^{3} / \mathrm{s}\right)$ \\
\cline { 1 - 2 } $07-22-59$ & $\mathrm{c} 0.48$ & $05-27-69$ & 0.45 \\
$08-03-59$ & $\mathrm{c} 0.55$ & $09-13-70$ & 0.40 \\
$08-12-59$ & $\mathrm{c} 0.28$ & $09-30-70$ & $\mathrm{~b} 0.35$ \\
$09-28-60$ & 0.29 & $03-13-74$ & 0.24 \\
$10-04-60$ & 0.25 & $11-04-74$ & 0.11 \\
$09-20-61$ & 0.37 & $09-23-75$ & 0.15 \\
$09-28-61$ & $\mathrm{~b} 0.18$ & $05-04-83$ & 0.33 \\
$02-04-63$ & $\mathrm{~b} 0.30$ & $08-07-86$ & 0.22 \\
$02-22-63$ & 0.36 & $09-04-86$ & 0.33 \\
$05-14-63$ & 0.38 & $07-01-87$ & 0.26 \\
$05-13-64$ & $\mathrm{~b} 0.49$ & $09-04-87$ & 0.22 \\
$06-14-65$ & $\mathrm{a} 0.84$ & $05-24-89$ & 0.36 \\
$05-26-67$ & 0.46 & $08-23-89$ & 0.14 \\
$04-30-68$ & 0.58 & $09-23-90$ & 0.20 \\
$05-21-69$ & 0.64 & &
\end{tabular}
a, includes surface runoff
b, revision
c, not previously published 
Table 3. Low-flow characteristics for low-flow partial-record stations on Tutuila, American Samoa--Continued

$$
16950000 \text { Utumoa pipeline diversion near Pago Pago. }
$$

Location.--Lat $14^{\circ} 17 \cdot 33^{\prime \prime S .,}$ long $170^{\circ} 42 \cdot 20 " \mathrm{~W}$., at stilling basin $150 \mathrm{ft}$ below diversion on Utumoa stream and 1.1 miles south of Pago Pago (revision).

Drainage area.--N/A. Tributary to. --N/A.

Type of site.--Daily record station.

Period of record.--April 1957 - June 1958.

Average discharge.--not determined.

Extremes for period of record.--Maximum not determined; No flow Feb. 9 , 1958.

Low-Flow frequency. --None.

Remarks. - These records combined with those of utumoa Stream (16950500 old) will show total flow at 460 ft altitude. 
Table 3. Low-flow characteristics for low-flow partial-record stations on Tutuila, American Samoa--Continued

$$
16950500 \text { (old) Utumoa stream at Pago Pago. }
$$

Location.--Lat $14^{\circ} 17^{\prime} 33^{\prime \prime S}$., long $170^{\circ} 42 \cdot 20^{\prime \prime} \mathrm{W} ., 150$ feet downstream from pipeline diversion, 0.5 mile upstream from mouth, and 1.1 mile south of Pago Pago (revision).

Drainage area. $-0.08 \mathrm{mi}^{2} \quad$ Tributary to.--Vaipito stream

Type of site.--Daily record station.

Period of record. --1957-58, 1974 .

Low-flow frequency. --None.

Remarks.--Operated as a daily recording gage from April 1957 until June 1958. Municipal diversion located upstream of site.

List of measurements: total of 2 .

$\frac{\text { Date }}{09-22-58} \quad \frac{\text { Discharge }\left(\mathrm{ft}^{3} / \mathrm{s}\right)}{\mathrm{c} 0.31} \quad \frac{\text { Date }}{11-04-74} \quad \frac{\text { Discharge }\left(\mathrm{ft}^{3} / \mathrm{s}\right)}{\mathrm{c} 0.04}$

c, not previously published 
Table 3. Low-flow characteristics for low-flow partial-record stations on Tutuila, American Samoa--Continued

$$
16950500 \text { (new) Utumoa Stream at Pago Pago. }
$$

Location.--Lat $14^{\circ} 17^{\prime} 21^{\prime \prime S} .$, long $170^{\circ} 42^{\prime} 21^{\prime \prime W}, 0^{\prime} 0.2$ mile downstream from pipeline diversion, 0.3 mile upstream from mouth, and 0.8 mile south of Pago Pago (revision).

Drainage area.--0.17 $\mathrm{mi}^{2} \quad$ Tributary to.--Vaipito stream

Type of site.--Low-flow partial-record station.

Period of record.--1959-65, 1967-68, 1972, 1974-75.

\begin{tabular}{lcc}
\hline $\begin{array}{l}\text { Streamflow } \\
\text { characteristic }\end{array}$ & $\begin{array}{c}\text { Discharge } \\
\mathrm{ft}^{3} / \mathrm{s}\end{array}$ & $\begin{array}{c}\text { Accuracy } \\
\text { \%SE }\end{array}$ \\
\hline 7-day, 2-year low & 0.14 & 22.2 \\
7-day, 10-year low & 0.06 & 29.8 \\
Mean & 0.45 & 23.8 \\
Median & 0.25 & 15.5 \\
\hline
\end{tabular}

Basis of estimate.--Moments approach with station 16948000 .

Remarks.--Municipal diversion located upstream of site.

List of measurements: total of 17 .

\begin{tabular}{cccc} 
Date & Discharge $\left(\mathrm{ft}^{3} / \mathrm{s}\right)$ & Date & Discharge $\left(\mathrm{ft}^{3} / \mathrm{s}\right)$ \\
\hline $07-22-59$ & $\mathrm{c} 0.38$ & $05-14-63$ & $\mathrm{c} 0.48$ \\
$08-03-59$ & $\mathrm{c} 0.54$ & $05-13-64$ & 0.39 \\
$08-12-59$ & $\mathrm{c} 0.24$ & $06-14-65$ & $\mathrm{a} 1.22$ \\
$09-28-60$ & 0.17 & $05-29-67$ & 0.39 \\
$10-03-60$ & $\mathrm{~b} 0.13$ & $05-30-68$ & 0.67 \\
$09-20-61$ & 0.23 & $05-05-72$ & 0.14 \\
$10-02-61$ & 0.53 & $03-13-74$ & 0.07 \\
$02-04-63$ & 0.22 & $09-23-75$ & 0.08 \\
$02-22-63$ & $\mathrm{~b} 0.38$ & &
\end{tabular}
a, includes surface runoff
b, revision
c, not previously published 
Table 3. Low-flow characteristics for low-flow partial-record stations on Tutuila, American Samoa--Continued

\section{Vaipito Stream at Pago Pago.}

Location.--Lat 14\%16'57"S., long $170^{\circ} 42^{\prime} 16^{\prime \prime W} ., 800$ ft upstream from Pago Stream and $0.3 \mathrm{mile}$ southwest of highway junction in Pago Pago.

Drainage area.--0.75 $\mathrm{mi}^{2}$. Tributary to.--Pacific Ocean.

Type of site.--Low-flow partial-record station.

Period of record.--1966-67, 1969-70.

\begin{tabular}{lcc}
\hline Streamflow & $\begin{array}{c}\text { Discharge } \\
\mathrm{ft}^{3} / \mathrm{s}\end{array}$ & $\begin{array}{c}\text { Accuracy } \\
\text { characteristic }\end{array}$ \\
\hline 7-day, 2-year low & 0.65 & 28.7 \\
7-day, 10-year low & 0.30 & 45.0 \\
Mean & 6.40 & 30.5 \\
Median & 1.76 & 17.5 \\
\hline
\end{tabular}

Basis of estimate.--Graphical correlataion with 16948000.

Remarks. - All measurements are revisions from previously published ones. Pumping occurs from pool at site, all measurements below were made above pool. Municipal and domestic diversions upstream of site.

Iist of measurements: total of 9 .

\begin{tabular}{|c|c|c|c|}
\hline Date & Discharge $\left(\mathrm{ft}^{3} / \mathrm{s}\right)$ & Date & Discharge $\left(\mathrm{ft}^{3} / \mathrm{s}\right)$ \\
\hline $06-11-66$ & 3.72 & $09-30-68$ & 0.58 \\
\hline $06-30-66$ & 1.92 & $05-27-69$ & c1.36 \\
\hline $09-20-66$ & 3.32 & $08-05-69$ & 1.24 \\
\hline $11-29-66$ & 1.41 & $08-04-70$ & 1.55 \\
\hline $02-28-67$ & 1.91 & & \\
\hline
\end{tabular}

c, not previously published 
Table 3. Low-flow characteristics for low-flow partial-record stations on Tutuila, American Samoa--Continued

\section{Lalolamauta Stream at Aua.}

Location. - - Lat $14^{\circ} 16^{\prime} 25^{\prime \prime S} .$, long $170^{\circ} 39^{\prime} 31^{\prime \prime} \mathrm{W} ., 300$ ft upstream from Amano Stream and $0.4 \mathrm{mile}$ east of Aua.

Drainage area.--0.14 $\mathrm{mi}^{2}$. Tributary to.--Pacific Ocean

Type of site.--Low-flow partial-record station.

Period of record.--1959-61, 1963-65, 1968-70, 1974-77.

\begin{tabular}{lcc}
\hline $\begin{array}{l}\text { Streamflow } \\
\text { characteristic }\end{array}$ & $\begin{array}{c}\text { Discharge } \\
\mathrm{ft}^{3} / \mathrm{s}\end{array}$ & $\begin{array}{c}\text { Accuracy } \\
\text { oSE }\end{array}$ \\
\hline 7-day, 2-year low & 0.09 & 23.8 \\
7-day, 10-year low & 0.03 & 32.3 \\
Mean & 0.44 & 33.0 \\
Median & 0.21 & 21.7 \\
\hline
\end{tabular}

Basis of estimate.--Moments approach with station 16960000 .

List of measurements: total of 18 .

\begin{tabular}{cccc} 
Date & Discharge $\left(\mathrm{ft}^{3} / \mathrm{s}\right)$ & Date & Discharge $\left(\mathrm{ft}^{3} / \mathrm{s}\right)$ \\
\hline $01-02-59$ & 0.11 & $06-14-65$ & a 1.90 \\
$07-28-59$ & 0.10 & $04-30-68$ & 0.85 \\
$09-22-60$ & 0.09 & $09-22-69$ & 0.22 \\
$09-29-60$ & $\mathrm{~b} 0.07$ & $03-13-70$ & 0.83 \\
$09-20-61$ & 0.11 & $11-06-74$ & 0.12 \\
$09-28-61$ & 0.05 & $09-24-75$ & 0.12 \\
$02-07-63$ & $\mathrm{~b} 0.10$ & $09-16-76$ & 0.08 \\
$02-22-63$ & $\mathrm{~b} 0.13$ & $11-24-76$ & 0.05 \\
$05-13-64$ & $\mathrm{~b} 0.35$ & &
\end{tabular}
a, includes surface runoff
b, revision
c, not previously published 
Table 3. Low-flow characteristics for low-flow partial-record stations on Tutuila, American Samoa--Continued

\section{Matagimalie Stream at Aua.}

Location.--Lat $14^{\circ} 16^{\prime} 19^{\prime \prime} \mathrm{S} .$, long $170^{\circ} 39^{\prime} 50^{\prime \prime} \mathrm{W} ., 0.2$ mile north of Aua and 0.2 mile upstream from mouth.

Drainage area.--0.03 $\mathrm{mi}^{2}$. Tributary to.--Lalolamauta stream

Type of site.--Low-flow partial-record station.

Period of record.--1959-61, 1963-65, 1968-69, 1971, 1974-76.

\begin{tabular}{lcc}
\hline $\begin{array}{l}\text { Streamflow } \\
\text { characteristic }\end{array}$ & $\begin{array}{c}\text { Discharge } \\
\mathrm{ft}^{3} / \mathrm{s}\end{array}$ & $\begin{array}{c}\text { Accuracy } \\
\text { oSE }\end{array}$ \\
\hline 7-day, 2-year low & 0.07 & 19.2 \\
7-day, 10-year low & 0.03 & 27.0 \\
Mean & 0.24 & 28.5 \\
Median & 0.14 & 18.5 \\
\hline
\end{tabular}

Basis of estimate.--Moments approach with station 16960000 .

List of measurements: total of 19 .

$\begin{array}{cccc}\text { Date } & \text { Discharge }\left(\mathrm{ft}^{3} / \mathrm{s}\right) & \text { Date } & \text { Discharge }\left(\mathrm{ft}^{3} / \mathrm{s}\right) \\ 01-02-59 & 0.12 & 04-30-68 & 0.19 \\ 07-28-59 & 0.10 & 05-21-69 & 0.09 \\ 09-22-60 & 0.12 & 05-22-69 & 0.20 \\ 09-29-60 & 0.12 & 09-22-71 & 0.06 \\ 09-20-61 & \mathrm{~b} 0.13 & 03-13-74 & 0.12 \\ 09-28-61 & 0.12 & 11-06-74 & 0.01 \\ 02-07-63 & 0.16 & 09-24-75 & 0.04 \\ 02-22-63 & 0.12 & 09-16-76 & 0.10 \\ 05-13-64 & 0.16 & 11-24-76 & \mathrm{c} 0.10 \\ 06-14-65 & \mathrm{a} 0.34 & & \end{array}$
$a$, includes surface runoff
b, revision
c, not previously published 
Table 3. Low-flow characteristics for low-flow partial-record stations on Tutuila, American Samoa--Continued

\section{Anasosopo Stream at Anasosopo.}

Location.--Lat $14^{\circ} 17^{\prime} 14^{\prime \prime S} .$, long $170^{\circ} 39^{\prime} 44^{\prime \prime} \mathrm{W} ., 400$ ft upstream from highway bridge at Anasosopo and 0.1 mile upstream from mouth.

Drainage area.--0.05 $\mathrm{mi}^{2} \quad$ Tributary to.--Pacific Ocean

Type of site.--Low-flow partial-record station.

Period of record. --1959-61, 1963-65, 1968, 1971, 1974-77.

\begin{tabular}{lcc}
\hline $\begin{array}{l}\text { Streamflow } \\
\text { characteristic }\end{array}$ & $\begin{array}{c}\text { Discharge } \\
\mathrm{ft}^{3} / \mathrm{s}\end{array}$ & $\begin{array}{c}\text { Accuracy } \\
\text { oSE }\end{array}$ \\
\hline 7-day, 2-year low & 0.04 & 18.4 \\
7-day, 10-year low & 0.02 & 25.2 \\
Mean & 0.37 & 32.1 \\
Median & 0.15 & 19.4 \\
\hline
\end{tabular}

Basis of estimate.--Moments approach with station 16912000 .

Remarks.--Diversion for domestic use upstream of site.

List of measurements: total of 18 .

\begin{tabular}{cc} 
Date & Discharge $\left(\mathrm{ft}^{3} / \mathrm{s}\right)$ \\
\hline $07-28-59$ & 0.06 \\
$08-04-59$ & 0.10 \\
$09-21-60$ & $\mathrm{~b} 0.10$ \\
$09-29-60$ & $\mathrm{~b} 0.07$ \\
$09-20-61$ & 0.08 \\
$09-28-61$ & 0.06 \\
$02-07-63$ & 0.08 \\
$02-22-63$ & 0.06 \\
$05-13-64$ & $\mathrm{~b} 0.35$
\end{tabular}

\begin{tabular}{cr} 
Date & Discharge $\left(\mathrm{ft}^{3} / \mathrm{s}\right)$ \\
\hline $06-14-65$ & $\mathrm{ab} 0.50$ \\
$04-30-68$ & 0.31 \\
$05-25-69$ & $\mathrm{c} 0.25$ \\
$09-29-71$ & 0.04 \\
$03-14-74$ & 0.06 \\
$11-06-74$ & 0.01 \\
$09-24-75$ & 0.05 \\
$09-16-76$ & 0.05 \\
$11-24-76$ & $\mathrm{C} 0.08$
\end{tabular}
a, includes surface runoff
b, revision
c, not previously published 
Table 3. Low-flow characteristics for low-flow partial-record stations on Tutuila, American Samoa--Continued

\section{Vaisina Stream at Lauliifou.}

Location.--Lat $14^{\circ} 17^{\prime} 34^{\prime \prime S} .$, long $170^{\circ} 39^{\prime} 25^{\prime \prime W},{ }^{\prime} 0.1$ mile north of Lauliifou and $600 \mathrm{ft}$ upstream from highway bridge.

Drainage area.--0.06 $\mathrm{mi}^{2} \quad$ Tributary to.--Pacific Ocean

Type of site.--Low-flow partial-record station.

Period of record.--1959-61, 1963-65, 1968, 1974.

\begin{tabular}{lcc}
\hline $\begin{array}{l}\text { Streamflow } \\
\text { characteristic }\end{array}$ & $\begin{array}{c}\text { Discharge } \\
\mathrm{ft}^{3} / \mathrm{s}\end{array}$ & $\begin{array}{c}\text { Accuracy } \\
\text { oSE }\end{array}$ \\
\hline 7-day, 2-year low & 0.02 & 20.5 \\
7-day, 10-year low & $<0.01$ & 28.2 \\
Mean & 0.16 & 24.3 \\
Median & 0.06 & 15.1 \\
\hline
\end{tabular}

Basis of estimate.--Moments approach with station 16912000 .

Remarks.--Stream has been observed to go dry.

List of measurements: total of 12 .

$\begin{array}{cccc}\text { Date } & \text { Discharge }\left(\mathrm{ft}^{3} / \mathrm{s}\right) & \text { Date } & \text { Discharge }\left(\mathrm{ft}^{3} / \mathrm{s}\right) \\ 07-28-59 & 0.02 & 02-07-63 & 0.05 \\ 08-04-59 & 0.03 & 02-22-63 & 0.05 \\ 09-21-60 & 0.06 & 05-13-64 & \mathrm{~b} 0.18 \\ 09-29-60 & 0.05 & 06-17-65 & 0.16 \\ 09-20-61 & \mathrm{~b} 0.02 & 04-30-68 & \mathrm{~b} 0.12 \\ 09-28-61 & 0.02 & 03-14-74 & 0.03\end{array}$

b, revision 
Table 3. Low-flow characteristics for low-flow partial-record stations on Tutuila, American Samoa--Continued

16956000 Vaitele stream at Laulituai.

Location.--Lat $14^{\circ} 17^{\prime} 05^{\mathrm{NS}}$, , long $170^{\circ} 39^{\circ} 07^{\mathrm{WW}} \mathrm{W}, 200$ ft upstream from unnamed tributary, $0.5 \mathrm{mile}$ north of Lauliituai, and 0.7 mile upstream from mouth.

Drainage area.--0.19 $\mathrm{mi}^{2} \quad$ Tributary to.--Pacific Ocean

Type of site.--Low-flow partial-record station.

Period of record.--1959-61, 1963-65, 1968, 1970, 1974-77.

\begin{tabular}{lcc}
\hline Streamflow & $\begin{array}{c}\text { Discharge } \\
\text { characteristic }\end{array}$ & $\begin{array}{c}\text { Accuracy } \\
\mathrm{ft}^{3} / \mathrm{s}\end{array}$ \\
\hline 7-day, 2-year low & 0.33 & 11.8 \\
7-day, 10-year low & 0.19 & 15.5 \\
Mean & 1.07 & 15.1 \\
Median & 0.65 & 9.9 \\
\hline
\end{tabular}

Basis of estimate.--Moments approach with 16912000 .

Remarks.--Diversion for domestic use upstream of site at altitude $140 \mathrm{ft}$ starting in 1964 .

List of measurements: total of 18 .

\begin{tabular}{|c|c|c|c|}
\hline Date & Discharge $\left(\mathrm{ft}^{3} / \mathrm{s}\right)$ & Date & Discharge $\left(f t^{3} / s\right)$ \\
\hline $07-24-59$ & $\mathrm{~b} 0.33$ & $\overline{05-22-64}$ & 1.56 \\
\hline $08-06-59$ & bo. 57 & $06-17-65$ & 1.61 \\
\hline $09-21-60$ & $\mathrm{~b} 0.39$ & $04-30-68$ & $\mathrm{~b} 1.08$ \\
\hline $09-29-60$ & $\mathrm{~b} 0.37$ & $09-15-70$ & 0.75 \\
\hline $09-20-61$ & $\mathrm{~b} 0.38$ & $03-12-74$ & 0.57 \\
\hline $09-28-61$ & $\mathrm{~b} 0.41$ & $11-05-74$ & 0.24 \\
\hline $02-07-63$ & 0.43 & $09-24-75$ & 0.28 \\
\hline $02-22-63$ & 0.48 & $09-21-76$ & 0.36 \\
\hline $05-13-64$ & 0.62 & $11-24-76$ & $\mathrm{c} 0.64$ \\
\hline
\end{tabular}


Table 3. Low-flow characteristics for low-flow partial-record stations on Tutuila, American Samoa--Continued

\section{Maga Stream at Laulittuai.}

Location.--Lat $14^{\circ} 17^{\prime} 12^{\prime \prime S ., ~ l o n g ~} 170^{\circ} 39^{\prime} 09^{\prime \prime} \mathrm{W} ., 0.1$ mile upstream from mouth and 0.4 mile north of Laulituai.

Drainage area.--0.05 $\mathrm{mi}^{2} \quad$ Tributary to.--Vaitele stream

Type of site.--Low-flow partial-record station.

Period of record.--1959-61, 1963-65, 1968, 1974-75.

\begin{tabular}{lcc}
\hline $\begin{array}{l}\text { Streamflow } \\
\text { characteristic }\end{array}$ & $\begin{array}{c}\text { Discharge } \\
\mathrm{ft}^{3} / \mathrm{s}\end{array}$ & $\begin{array}{c}\text { Accuracy } \\
\mathrm{oSE}\end{array}$ \\
\hline 7-day, 2-year low & 0.02 & 17.6 \\
7-day, 10-year low & 0.01 & 23.4 \\
Mean & 0.11 & 20.6 \\
Median & 0.05 & 13.2 \\
\hline
\end{tabular}

Basis of estimate.--Moments approach with station 16912000 .

List of measurements: total of 14 .

\begin{tabular}{cccc} 
Date & Discharge $\left(\mathrm{ft}^{3} / \mathrm{s}\right)$ & Date & Discharge $\left(\mathrm{ft}^{3} / \mathrm{s}\right)$ \\
\hline $07-24-59$ & $\mathrm{~b} 0.03$ & $02-22-63$ & $\mathrm{~b} 0.04$ \\
$08-06-59$ & $\mathrm{~b} 0.05$ & $05-13-64$ & 0.16 \\
$09-21-60$ & $\mathrm{~b} 0.03$ & $05-22-64$ & $\mathrm{~b} 0.07$ \\
$09-29-60$ & $\mathrm{~b} 0.05$ & $06-17-65$ & 0.09 \\
$09-20-61$ & $\mathrm{~b} 0.02$ & $04-30-68$ & 0.10 \\
$09-28-61$ & $\mathrm{~b} 0.03$ & $03-14-74$ & 0.03 \\
$02-07-63$ & 0.05 & $09-24-75$ & 0.01
\end{tabular}

b, revision 
Table 3. Low-flow characteristics for low-flow partial-record stations on Tutuila, American Samoa--Continued

$$
16957000 \text { Lesea Stream at Lauliituai. }
$$

Location.--Lat $14^{\circ} 17^{\prime} 19^{\prime \prime} \mathrm{S} .$, long $170^{\circ} 39^{\prime} 00^{\prime \prime} \mathrm{W} ., 0.1$ mile upstream from mouth and 0.3 mile northeast of Laulituai.

Drainage area.--0.02 $\mathrm{mi}^{2} \quad$ Tributary to.--Vaitele Stream.

Type of site.--Low-flow partial-record station.

Period of record.--1959-61, 1963-65, 1968, 1974-76.

\begin{tabular}{lcc}
\hline $\begin{array}{l}\text { Streamflow } \\
\text { characteristic }\end{array}$ & $\begin{array}{c}\text { Discharge } \\
\mathrm{ft}^{3} / \mathrm{s}\end{array}$ & $\begin{array}{c}\text { Accuracy } \\
\text { \%SE }\end{array}$ \\
\hline 7-day, 2-year low & 0.13 & 22.7 \\
7-day, 10-year low & 0.05 & 29.5 \\
Mean & 0.68 & 33.0 \\
Median & 0.32 & 20.2 \\
\hline
\end{tabular}

Basis of estimate.--Moments approach with station 16912000 .

List of measurements: total of 17 .

\begin{tabular}{cccc} 
Date & Discharge $\left(\mathrm{ft}^{3} / \mathrm{s}\right)$ & Date & Discharge $\left(\mathrm{ft}^{3} / \mathrm{s}\right)$ \\
\hline $07-24-59$ & 0.17 & $05-22-64$ & be1.15 \\
$08-06-59$ & 0.23 & $06-17-65$ & $\mathrm{e} 1.01$ \\
$09-21-60$ & 0.19 & $04-30-68$ & 0.64 \\
$09-29-60$ & $\mathrm{~b} 0.15$ & $03-12-74$ & 0.28 \\
$09-20-61$ & 0.12 & $11-06-74$ & 0.14 \\
$09-28-61$ & 0.12 & $09-24-75$ & 0.12 \\
$02-07-63$ & $\mathrm{~b} 0.04$ & $09-21-76$ & 0.19 \\
$02-22-63$ & 0.22 & $11-24-76$ & $\mathrm{c} 0.23$ \\
$05-13-64$ & 0.65 & &
\end{tabular}

b, revision

c, not previously published

e, may include surface runoff 
Table 3. Low-flow characteristics for low-flow partial-record stations on Tutuila, American Samoa--Continued

\section{Visa Stream at Alega.}

Location.--Lat $14^{\circ} 17^{\prime} 21^{\prime \prime S .,}$ long $170^{\circ} 38^{\prime} 37^{\prime \prime} \mathrm{W} ., 0.2$ mile upstream from mouth and 0.5 mile southwest of Alega.

Drainage area.--0.10 $\mathrm{mi}^{2} \quad$ Tributary to.--Pacific Ocean.

Type of site.--Low-flow partial-record station.

Period of record.--1959-61, 1963-65, 1967-69, 1971, 1974-77.

\begin{tabular}{lcc}
\hline $\begin{array}{l}\text { Streamflow } \\
\text { characteristic }\end{array}$ & $\begin{array}{c}\text { Discharge } \\
\mathrm{ft}^{3} / \mathrm{s}\end{array}$ & $\begin{array}{c}\text { Accuracy } \\
\% S E\end{array}$ \\
\hline 7-day, 2-year low & 0.04 & 24.0 \\
7-day, 10-year low & 0.01 & 34.4 \\
Mean & 0.63 & 33.3 \\
Median & 0.20 & 19.3 \\
\hline
\end{tabular}

Basis of estimate.--Moments approach with station 16912000 .

Remarks.--Diversion for domestic use upstream of site starting in 1974.

List of measurements: total of 21 .

\begin{tabular}{|c|c|c|c|}
\hline Date & Discharge $\left(\mathrm{Et}^{3} / \mathrm{s}\right)$ & Date & Discharge $\left(\mathrm{ft}^{3} / \mathrm{s}\right)$ \\
\hline $11-03-58$ & 0.09 & $05-25-67$ & b0 0.35 \\
\hline $07-24-59$ & 0.07 & $05-02-68$ & 0.28 \\
\hline $08-11-59$ & 0.08 & $10-03-68$ & 0.14 \\
\hline $09-21-60$ & 0.11 & $05-27-69$ & 0.23 \\
\hline $09-29-60$ & $\mathrm{~b} 0.07$ & $05-06-71$ & 0.35 \\
\hline $09-20-61$ & b0. 04 & $03-12-74$ & 0.10 \\
\hline $09-27-61$ & b0. 02 & $11-05-74$ & g0.01 \\
\hline $02-08-63$ & $\mathrm{~b} 0.10$ & $09-24-75$ & 0.05 \\
\hline $02-22-63$ & $\mathrm{~b} 0.10$ & $09-21-76$ & 0.09 \\
\hline $05-13-64$ & 0.57 & $11-24-76$ & $\operatorname{cg} 0.04$ \\
\hline $06-14-65$ & $\mathrm{ab0} .78$ & & \\
\hline
\end{tabular}

a, includes surface runoff

b, revision

c, not previously published

$\mathrm{g}$, measurement made below diversion 
Table 3. Low-flow characteristics for low-flow partial-record stations on Tutuila, American Samoa--Continued

\section{Visa Stream tributary at Aumi.}

Location.--Lat $14^{\circ} 17^{\prime} 24^{\prime \prime S ., ~ l o n g ~} 170^{\circ} 38^{\prime} 35^{\prime \prime} \mathrm{W} ., 200$ ft upstream from mouth and 0.3 mile northeast of Aumi.

Drainage area. $-0.02 \mathrm{mi}^{2}$. Tributary to.--Visa stream.

Type of site.--Low-flow partial-record station.

Period of record.--1959-61, 1963-65, 1967-69, 1971, 1974-75.

\begin{tabular}{lcc}
\hline $\begin{array}{l}\text { Streamflow } \\
\text { characteristic }\end{array}$ & $\begin{array}{c}\text { Discharge } \\
\mathrm{ft}^{3} / \mathrm{s}\end{array}$ & $\begin{array}{c}\text { Accuracy } \\
\text { \%SE }\end{array}$ \\
\hline 7-day, 2-year low & 0.05 & 29.3 \\
7-day, 10-year low & 0.02 & 58.1 \\
Mean & 0.22 & 37.6 \\
Median & 0.12 & 24.9 \\
\hline
\end{tabular}

Basis of estimate.--Graphical correlation with 16960000 .

List of measurements: total of 21 .

\begin{tabular}{|c|c|c|c|}
\hline Date & Discharge $\left(\mathrm{ft}^{3} / \mathrm{s}\right)$ & Date & Discharge $\left(\mathrm{ft}^{3} / \mathrm{s}\right)$ \\
\hline $11-03-58$ & 0.02 & $05-25-67$ & 0.20 \\
\hline $07-24-59$ & 0.03 & $05-02-68$ & 0.20 \\
\hline $08-11-59$ & 0.03 & $10-03-68$ & 0.10 \\
\hline $09-21-60$ & 0.06 & $05-27-69$ & 0.24 \\
\hline $09-29-60$ & 0.03 & $05-06-71$ & c0.19 \\
\hline $09-20-61$ & b0. 04 & $09-22-71$ & 0.11 \\
\hline $09-27-61$ & 0.05 & $03-12-74$ & 0.12 \\
\hline $02-08-63$ & 0.05 & $11-05-74$ & 0.08 \\
\hline $02-22-63$ & 0.05 & $09-24-75$ & 0.10 \\
\hline $05-13-64$ & $\mathrm{~b} 0.10$ & $11-24-76$ & $\mathrm{C} 0.14$ \\
\hline $06-14-65$ & $\mathrm{a} 0.17$ & & \\
\hline
\end{tabular}
a, includes surface runoff
b, revision
c, not previously published 
Table 3. Low-flow characteristics for low-flow partial-record stations on Tutuila, American Samoa--Continued

\section{Visa Stream at Aumi.}

Location.--Lat $14^{\circ} 17^{\prime} 27^{\prime \prime S ., ~} 170^{\circ} 38^{\prime} 36^{\prime \prime W} ., 100 \mathrm{ft}$ upstream from highway bridge and $0.2 \mathrm{mile}$ east of Aumi.

Drainage area.--0.16 $\mathrm{mi}^{2} \quad$ Tributary to.--Pacific Ocean.

Type of site.--Low-flow partial-record station.

Period of record.--1957-58, 1963-64, 1968-71, 1974-77.

\begin{tabular}{lcc}
\hline $\begin{array}{l}\text { Streamflow } \\
\text { characteristic }\end{array}$ & $\begin{array}{c}\text { Discharge } \\
\mathrm{ft}^{3} / \mathrm{s}\end{array}$ & $\begin{array}{c}\text { Accuracy } \\
\text { \%SE }\end{array}$ \\
\hline 7-day, 2-year low & 0.11 & 15.6 \\
7-day, 10-year low & 0.05 & 21.3 \\
Mean & 0.84 & 20.8 \\
Median & 0.37 & 13.6 \\
\hline
\end{tabular}

Basis of estimate.--Moments approach with station 16912000 .

Remarks. --Operated as a daily record station from April 1957 to June 1958. Diversion for domestic use upstream of site at altitude $200 \mathrm{ft}$ starting in 1974 and at altitude 50 ft after period of record.

List of measurements: total of 18 .

$\begin{array}{lccc}\frac{\text { Date }}{04-08-57} & \text { Discharge }\left(\mathrm{ft}^{3} / \mathrm{s}\right) & \text { Date } & \text { Discharge (ft } 3 / \mathrm{s}) \\ 04-12-57 & \mathrm{c} 0.37 & 05-27-69 & 0.23 \\ 04-25-57 & \mathrm{c} 1.12 & 09-11-70 & 0.26 \\ 02-08-63 & \mathrm{c} 0.46 & 05-06-71 & \mathrm{c} 0.51 \\ 02-22-63 & \mathrm{~b} 0.30 & 09-22-71 & 0.13 \\ 05-22-64 & 0.27 & 03-12-74 & 0.34 \\ 05-02-68 & 0.56 & 11-05-74 & 0.10 \\ 10-03-68 & 0.19 & 09-24-75 & 0.14 \\ 05-20-69 & 0.49 & 09-21-76 & 0.04 \\ & & 11-24-76 & \mathrm{c} 0.13 \\ \text { b, revision } & & & \\ \text { C, not previously published } & & \end{array}$


Table 3. Low-flow characteristics for low-flow partial-record stations on Tutuila, American Samoa--Continued

\section{Alega Stream tributary at Alega.}

Location.--Lat $14^{\circ} 16^{\prime} 57^{\prime \prime S}$., long 170 $38^{\prime} 16^{\prime \prime} \mathrm{W} ., 300$ ft upstream from mouth and 0.2 mile north of Alega.

Drainage area.--0.04 $\mathrm{mi}^{2}$. Tributary to.--Alega stream.

Type of site.--Low-flow partial-record station.

Period of record.--1959-61, 1963-65, 1967-69, 1974, 1976.

\begin{tabular}{lcc}
\hline $\begin{array}{l}\text { Streamflow } \\
\text { characteristic }\end{array}$ & $\begin{array}{c}\text { Discharge } \\
\mathrm{ft}^{3} / \mathrm{s}\end{array}$ & $\begin{array}{c}\text { Accuracy } \\
\text { \%SE }\end{array}$ \\
\hline 7-day, 2-year low & 0.15 & 14.6 \\
7-day, 10-year low & 0.08 & 19.5 \\
Mean & 0.40 & 21.3 \\
Median & 0.26 & 12.7 \\
\hline
\end{tabular}

Basis of estimate.--Moments approach with stations 16912000 and 16960000 .

List of measurements: total of 19 .

\begin{tabular}{|c|c|c|c|}
\hline Date & Discharge $\left(\mathrm{Et}^{3} / \mathrm{s}\right)$ & Date & Discharge $\left(\mathrm{ft}^{3} / \mathrm{s}\right)$ \\
\hline $11-03-58$ & $\mathrm{C} 0.14$ & $05-20-64$ & a1.02 \\
\hline $08-03-59$ & c0.19 & $06-17-65$ & 0.59 \\
\hline $08-11-59$ & $\mathrm{c} 0.16$ & $05-26-67$ & 0.32 \\
\hline $09-21-60$ & $\mathrm{C} 0.21$ & $05-02-68$ & 0.39 \\
\hline $09-29-60$ & $\mathrm{C} 0.21$ & $10-03-68$ & $\mathrm{C} 0.05$ \\
\hline $09-22-61$ & $\mathrm{~b} 0.30$ & $05-20-69$ & 0.31 \\
\hline $09-27-61$ & 0.17 & $08-13-74$ & 0.12 \\
\hline $02-08-63$ & 0.19 & $09-16-74$ & 0.10 \\
\hline $02-14-63$ & 0.22 & $10-07-75$ & 0.15 \\
\hline $05-15-64$ & $\mathrm{~b} 0.38$ & & \\
\hline
\end{tabular}
a, includes surface runoff
b, revision
c, not previously published 
Table 3. Low-flow characteristics for low-flow partial-record stations on Tutuila, American Samoa--Continued

\section{Mulioevai Stream at Auto.}

Location.--Lat 14\%16'37"S., long 170 37'54"W., 400 ft downstream from unnamed tributary, 0.5 mile northwest of Auto, and 0.5 mile upstream from mouth (revision).

Drainage area.--0.22 $\mathrm{mi}^{2}$. Tributary to.--Pacific Ocean

Type of site.--Low-flow partial-record station.

Period of record.--1959-61, 1963-65, 1968-69, 1974, 1976.

\begin{tabular}{lcc}
\hline $\begin{array}{l}\text { Streamflow } \\
\text { characteristic }\end{array}$ & $\begin{array}{c}\text { Discharge } \\
\mathrm{ft}^{3} / \mathrm{s}\end{array}$ & $\begin{array}{c}\text { Accuracy } \\
\text { oSE }\end{array}$ \\
\hline 7-day, 2-year low & 0.16 & 13.4 \\
7-day, 10-year low & 0.08 & 18.5 \\
Mean & 1.01 & 14.4 \\
Median & 0.48 & 10.1 \\
\hline
\end{tabular}

Basis of estimate.--Moments approach with station 16912000 .

Remarks. - Stream observed dry downstream of site in 1974.

List of measurements: total of 16 .

\begin{tabular}{|c|c|c|c|}
\hline Date & Discharge $\left(\mathrm{ft}^{3} / \mathrm{s}\right)$ & Date & Discharge $\left(\mathrm{ft}^{3} / \mathrm{s}\right)$ \\
\hline $11-03-58$ & 0.27 & $05-15-64$ & 0.87 \\
\hline $08-03-59$ & 0.38 & $05-20-64$ & 0.98 \\
\hline $09-22-60$ & $\mathrm{~b} 0.35$ & $06-17-65$ & a1. 67 \\
\hline $09-29-60$ & 0.28 & $05-02-68$ & 0.76 \\
\hline $09-22-61$ & 0.16 & $05-23-69$ & 0.57 \\
\hline $09-29-61$ & 0.16 & $08-19-74$ & 0.22 \\
\hline $02-08-63$ & $\mathrm{~b} 0.38$ & $08-19-74$ & 0.21 \\
\hline $02-14-63$ & 0.40 & $09-21-76$ & 0.13 \\
\hline
\end{tabular}
a, includes surface runoff
b, revision 
Table 3. Low-flow characteristics for low-flow partial-record stations on Tutuila, American Samoa--Continued

\section{Laloi Stream at Amouli.}

Location.--Lat $14^{\circ} 16^{\prime} 43^{\prime \mathrm{S}} .$, long $170^{\circ} 35^{\prime} 16^{\prime \prime W} ., 0.2$ mile upstream from Fusiloa Stream and 0.3 mile west of Amouli.

Drainage area.--0.09 $\mathrm{mi}^{2}$. Tributary to.--Fusiloa stream

Type of site.--Low-flow partial-record station.

Period of record.--1959-61, 1963-65, 1969, 1971, 1974.

\begin{tabular}{lcc}
\hline $\begin{array}{l}\text { Streamflow } \\
\text { characteristic }\end{array}$ & $\begin{array}{c}\text { Discharge } \\
\text { ft }^{3} / \mathrm{s}\end{array}$ & $\begin{array}{c}\text { Accuracy } \\
\text { \%SE }\end{array}$ \\
\hline 7-day, 2-year low & 0.03 & 18.1 \\
7-day, 10-year low & 0.01 & 24.9 \\
Mean & 0.32 & 17.6 \\
Median & 0.12 & 13.1 \\
\hline
\end{tabular}

Basis of estimate.--Moments approach with station 16912000 .

List of measurements: total of 16 .

\begin{tabular}{|c|c|c|c|}
\hline Date & Discharge $\left(\mathrm{ft}^{3} / \mathrm{s}\right)$ & Date & Discharge $\left(\mathrm{ft}^{3} / \mathrm{s}\right)$ \\
\hline $10-29-58$ & 0.08 & $02-21-63$ & $\mathrm{~b} 0.07$ \\
\hline $07-29-59$ & 0.03 & $05-15-64$ & 0.22 \\
\hline $08-11-59$ & 0.04 & $05-22-64$ & 0.32 \\
\hline $09-22-60$ & 0.06 & $06-16-65$ & $\mathrm{e} 0.54$ \\
\hline $09-29-60$ & $\mathrm{~b} 0.04$ & $05-21-69$ & 0.14 \\
\hline $09-21-61$ & $\mathrm{~b} 0.04$ & $10-16-70$ & 0.07 \\
\hline $09-29-61$ & 0.02 & $09-22-71$ & 0.06 \\
\hline $02-08-63$ & 0.11 & $03-11-74$ & 0.15 \\
\hline
\end{tabular}

b, revision

e, may include surface runoff 
Table 3. Low-flow characteristics for low-flow partial-record stations on Tutuila, American Samoa--Continued

\section{Televai Stream at Amouli.}

Location.--Lat $14^{\circ} 16^{\prime} 25^{\prime \prime S}$., long $170^{\circ} 34^{\prime} 55^{\prime \prime} \mathrm{W} ., 50$ ft downstream from unnamed tributary, 0.1 mile upstream from Tuavaa stream, and $0.3 \mathrm{mile}$ north of Amouli.

Drainage area.--0.10 $\mathrm{mi}^{2} \quad$ Tributary to.--Pacific Ocean.

Type of site.--Low-flow partial-record station.

Period of record.--1959-61, 1963-65, 1968-71, 1974-76.

\begin{tabular}{lcc}
\hline Streamflow & $\begin{array}{c}\text { Discharge } \\
\mathrm{ft}^{3} / \mathrm{s}\end{array}$ & $\begin{array}{c}\text { Accuracy } \\
\text { characteristic }\end{array}$ \\
\hline 7-day, 2-year low & 0.02 & 24.8 \\
7-day, 10-year low & $<0.01$ & 35.0 \\
Mean & 0.45 & 28.9 \\
Median & 0.11 & 18.9 \\
\hline
\end{tabular}

Basis of estimate.--Moments approach with station 16912000 .

List of measurements: total of 20 .

\begin{tabular}{|c|c|c|c|}
\hline Date & Discharge $\left(\mathrm{ft}^{3} / \mathrm{s}\right)$ & Date & Discharge $\left(\mathrm{ft}^{3} / \mathrm{s}\right)$ \\
\hline $10-17-58$ & 0.06 & $05-22-64$ & b0 0.27 \\
\hline $07-29-59$ & 0.03 & $06-16-65$ & $\mathrm{a} 0.42$ \\
\hline $08-11-59$ & 0.04 & $05-10-68$ & 0.22 \\
\hline $09-22-60$ & 0.02 & $05-21-69$ & 0.11 \\
\hline $09-29-60$ & $\mathrm{~b} 0.04$ & $09-12-70$ & 0.10 \\
\hline $09-21-61$ & $\mathrm{~b} 0.01$ & $10-02-70$ & 0.16 \\
\hline $09-29-61$ & 0.03 & $10-28-70$ & 0.06 \\
\hline $02-08-63$ & 0.09 & $03-11-74$ & 0.22 \\
\hline $02-21-63$ & 0.06 & $11-12-74$ & 0.01 \\
\hline $05-15-64$ & 0.23 & $11-11-75$ & 0.02 \\
\hline
\end{tabular}

a, includes surface runoff

b, revision 
Table 3. Low-flow characteristics for low-flow partial-record stations on Tutuila, American Samoa--Continued

\section{Leafu stream at Auasi.}

Location.--Lat $14^{\circ} 16^{\prime} 28^{\prime \prime} \mathrm{S} .$, long $170^{\circ} 34^{\prime} 26^{\prime \prime} \mathrm{W} ., 0.1$ mile north of Auasi and 0.2 mile upstream from mouth.

Drainage area.--0.12 $\mathrm{mi}^{2} \quad$ Tributary to.--Pacific Ocean

Type of site.--Low-flow partial-record station.

Period of record.--1959-61, 1963-65, 1968-71, 1976, 1981, 1983, 1985.

\begin{tabular}{lcc}
\hline $\begin{array}{l}\text { Streamflow } \\
\text { characteristic }\end{array}$ & $\begin{array}{c}\text { Discharge } \\
\mathrm{ft}^{3} / \mathrm{s}\end{array}$ & $\begin{array}{c}\text { Accuracy } \\
\text { 8SE }\end{array}$ \\
\hline 7-day, 2-year low & 0.05 & 19.7 \\
7-day, 10-year low & 0.02 & 28.7 \\
Mean & 0.24 & 18.2 \\
Median & 0.12 & 13.2 \\
\hline
\end{tabular}

Basis of estimate.--Moments approach with 16960000 .

List of measurements: total of 20 .

\begin{tabular}{|c|c|c|c|}
\hline Date & Discharge $\left(\mathrm{ft}^{3} / \mathrm{s}\right)$ & Date & Discharge $\left(\mathrm{ft}^{3} / \mathrm{s}\right)$ \\
\hline $10-29-58$ & 0.08 & $05-22-64$ & b0. 30 \\
\hline $07-30-59$ & 0.11 & $06-16-65$ & $\mathrm{ab0} .47$ \\
\hline $08-11-59$ & $\mathrm{~b} 0.10$ & $05-07-68$ & 0.26 \\
\hline $09-22-60$ & 0.09 & $05-23-69$ & 0.26 \\
\hline $09-28-60$ & 0.06 & $09-15-70$ & 0.07 \\
\hline $09-21-61$ & 0.06 & $10-06-70$ & 0.05 \\
\hline $09-29-61$ & 0.06 & $10-01-75$ & 0.06 \\
\hline $02-07-63$ & $\mathrm{~b} 0.10$ & $09-21-81$ & 0.05 \\
\hline $02-21-63$ & 0.11 & $10-20-82$ & 0.04 \\
\hline $05-14-64$ & $\mathrm{~b} 0.27$ & $09-06-85$ & 0.01 \\
\hline
\end{tabular}
a, includes surface runoff
b, revision 
Table 3. Low-flow characteristics for low-flow partial-record stations on Tutuila, American Samoa--Continued

\section{Vaialili stream at Alao.}

Location.--Lat $14^{\circ} 16^{\prime} 15^{\prime S} \mathrm{~S}$, , long $170^{\circ} 34^{\prime} 08^{\prime \prime} \mathrm{W} ., 0.2$ mile upstream from Vaifusi stream and 0.5 mile southwest of Alao.

Drainage area. $--0.10 \mathrm{mi}^{2} \quad$ Tributary to.--Mulivaitele stream.

Type of site.--Low-flow partial-record station.

Period of record.--1959-61, 1963-65, 1968, 1970-71, 1974-76.

\begin{tabular}{lcc}
\hline $\begin{array}{l}\text { Streamflow } \\
\text { characteristic }\end{array}$ & $\begin{array}{c}\text { Discharge } \\
\mathrm{ft}^{3} / \mathrm{s}\end{array}$ & $\begin{array}{c}\text { Accuracy } \\
\text { \%SE }\end{array}$ \\
\hline 7-day, 2-year low & 0.03 & 17.2 \\
7-day, 10-year low & 0.02 & 26.9 \\
Mean & 0.14 & 19.3 \\
Median & 0.08 & 12.3 \\
\hline
\end{tabular}

Basis of estimate.--Graphical correlation with station 16912000 .

List of measurements: total of 18 .

\begin{tabular}{|c|c|c|c|}
\hline Date & Discharge $\left(\mathrm{ft}^{3} / \mathrm{s}\right)$ & Date & Discharge $\left(\mathrm{ft}^{3} / \mathrm{s}\right)$ \\
\hline $10-28-58$ & 0.06 & $05-14-64$ & $\mathrm{~b} 0.12$ \\
\hline $07-29-59$ & 0.05 & $05-18-64$ & f0.09 \\
\hline $08-11-59$ & 0.07 & $06-15-65$ & $\mathrm{ab} 0.38$ \\
\hline $09-21-60$ & 0.06 & $05-02-68$ & 0.20 \\
\hline $09-28-60$ & $\mathrm{~b} 0.04$ & $09-15-70$ & 0.07 \\
\hline $09-21-61$ & $\mathrm{~b} 0.04$ & $10-06-70$ & 0.06 \\
\hline $09-28-61$ & 0.03 & $07-15-74$ & $\mathrm{~b} 0.05$ \\
\hline $02-07-63$ & 0.11 & $09-30-75$ & 0.07 \\
\hline $02-18-63$ & b0. 10 & $09-13-76$ & 0.03 \\
\hline
\end{tabular}
a, includes surface runoff
b, revision
$f$, surface runoff at index station on this date 
Table 3. Low-flow characteristics for low-flow partial-record stations on Tutuila, American Samoa--Continued

\section{Vaifusi Stream at Alao.}

Location.--Lat $14^{\circ} 16^{\prime} 08^{\prime \prime S} .$, long $170^{\circ} 34^{\prime} 05^{\prime \prime} \mathrm{W} ., 400$ ft upstream from mouth and 0.3 mile west of Alao.

Drainage area.--0.02 $\mathrm{mi}^{2} \quad$ Tributary to.--Vaialiti stream

Type of site.--Low-flow partial-record station.

Period of record.--1959-61, 1963-65, 1968, 1970, 1974-75.

\begin{tabular}{lcc}
\hline $\begin{array}{l}\text { Streamflow } \\
\text { characteristic }\end{array}$ & $\begin{array}{c}\text { Discharge } \\
\mathrm{ft}^{3} / \mathrm{s}\end{array}$ & $\begin{array}{c}\text { Accuracy } \\
\text { \%SE }\end{array}$ \\
\hline 7-day, 2-year low & 0.01 & 22.0 \\
7-day, 10-year low & $<0.01$ & 38.8 \\
Mean & 0.03 & 23.5 \\
Median & 0.02 & 17.1 \\
\hline
\end{tabular}

Basis of estimate.--Graphical correlation with station 16960000 .

List of measurements: total of 17 .

\begin{tabular}{cccc} 
Date & Discharge $\left(\mathrm{ft}^{3} / \mathrm{s}\right)$ & Date & Discharge (ft \\
\cline { 1 - 1 } $10-28-58$ & 0.02 & $05-14-64$ & $\mathrm{~b})$ \\
$07-29-59$ & 0.02 & $05-18-64$ & 0.02 \\
$08-11-59$ & 0.01 & $06-15-65$ & $\mathrm{e} 0.05$ \\
$09-21-60$ & 0.03 & $05-02-68$ & 0.03 \\
$09-28-60$ & $\mathrm{~b} 0.01$ & $09-15-70$ & 0.01 \\
$09-21-61$ & $\mathrm{~b} 0.01$ & $07-15-74$ & 0 \\
$09-28-61$ & 0.02 & $11-13-74$ & 0.01 \\
$02-07-63$ & 0.02 & $09-30-75$ & 0.01 \\
$02-18-63$ & 0.02 & &
\end{tabular}

b, revision

e, may include surface runoff 
Table 4. Low-flow characteristics for miscellaneous sites on Tutuila, American Samoa

1. Right Bank tributary to Vaitolu stream near Aoa.

Location.--Lat $14^{\circ} 16^{\prime} 20^{\prime \prime S ., ~ l o n g ~} 170^{\circ} 35^{\prime} 32^{\prime \prime} \mathrm{W} ., 10 \mathrm{ft}$ upstream from mouth, which is at Vaitolu stream gaging station (16906000) and 0.7 mile southwest of Aoa.

Drainage area.--0.02 $\mathrm{mi}^{2} \quad$ Tributary to.--Vaitolu stream.

Type of site.--Miscellaneous site.

Period of record. -1969 .

\begin{tabular}{lcc}
\hline $\begin{array}{l}\text { Streamflow } \\
\text { characteristic }\end{array}$ & $\begin{array}{c}\text { Discharge } \\
\mathrm{ft}^{3} / \mathrm{s}\end{array}$ & $\begin{array}{c}\text { Accuracy } \\
\frac{\mathrm{OSE}}{\mathrm{S}}\end{array}$ \\
\hline 7-day, 2-year low & $<0.01$ & 20.3 \\
7-day, 10-year low & 0 & 25.4 \\
Mean & 0.05 & 43.8 \\
Median & 0.02 & 21.8 \\
\hline
\end{tabular}

Basis of estimate.--Equations in table 7 .

Remarks.--Base-flow index of 0.175 computed using station 16912000 as index station with the 2-7-69 streamflow measurement.

List of measurements: total of 4 .

$\begin{array}{cccc}\frac{\text { Date }}{10-31-68} & \frac{\text { Discharge }\left(\mathrm{ft}^{3} / \mathrm{s}\right)}{0.06} & \frac{\text { Date }}{03-11-69} & \text { Discharge }\left(\mathrm{ft}^{3} / \mathrm{s}\right) \\ 02-07-69 & 0.01 & 09-03-69 & 0.02 \\ 0.07\end{array}$


Table 4. Low-flow characteristics for miscellaneous sites on Tutuila, American Samoa--Continued

2. Vaitolu Stream upstream of village intake near Aoa.

Location.--Lat $14^{\circ} 16^{\prime} 18^{\prime \prime S ., ~ l o n g ~} 170^{\circ} 35^{\prime} 34^{\prime \prime W}$, , 250 ft upstream from gaging station 16906000 and right bank tributary, and $0.7 \mathrm{mile}$ southwest of Aoa.

Drainage area.--0.15 $\mathrm{mi}^{2} \quad$ Tributary to.--Pacific Ocean

Type of site.--Miscellaneous site.

Period of record.--1969.

\begin{tabular}{lcc}
\hline Streamflow & $\begin{array}{c}\text { Discharge } \\
\text { characteristic }^{3} / \mathrm{S}\end{array}$ & $\begin{array}{c}\text { Accuracy } \\
\text { \%SE }\end{array}$ \\
\hline 7-day, 2-year low & 0.08 & 48.6 \\
7-day, 10-year low & 0.05 & 77.5 \\
Mean & 0.29 & 28.8 \\
Median & 0.17 & 18.8 \\
\hline
\end{tabular}

Basis of estimate.--Graphical correlation with station 16912000 .

Remarks.--Site used in regional regression.

List of measurements: total of 9 .

$\begin{array}{cccc}\frac{\text { Date }}{10-09-68} & \text { Discharge }\left(\mathrm{ft}^{3} / \mathrm{s}\right) & \frac{\text { Date }}{06-30-69} & \text { Discharge }\left(\mathrm{ft}^{3} / \mathrm{s}\right) \\ 10-31-68 & \mathrm{f} 0.05 & 07-23-69 & 0.11 \\ 12-10-68 & 0.24 & 09-03-69 & 0.24 \\ 02-07-69 & 0.17 & 09-30-69 & 0.52 \\ 03-11-69 & 0.13 & & 0.14\end{array}$

f, surface runoff at index station on this date 
Table 4. Low-flow characteristics for miscellaneous sites on Tutuila, American Samoa--Continued

\section{Tuavaa stream tributary No. 1 .}

Location.--Lat $14^{\circ} 16^{\prime} 31^{\prime \prime} \mathrm{S} .$, long $170^{\circ} 34^{\prime} 57^{\prime \prime}$ W., 10 ft upstream from confluence with Televai stream and 0.2 mile northwest of Amouli.

Drainage area.-- $<0.01 \mathrm{mi}^{2} \quad$ Tributary to.--Tuavaa stream.

Type of site.--Miscellaneous site.

Period of record.--1971.

Low-Flow frequency.--None computed, drainage area outside applicable range for region 1 equations (table 6 and 7). Stream is not perennial at site.

Remarks.--Previously published as Tuavaa Stream No. 4.

List of measurements: total of 1 .

Date Discharge (ft $\frac{3}{2 s}$

$01-05-71 \quad 0.10$

4. Tuavaa stream tributary No. 2 .

Location.--Lat $14^{\circ} 16^{\prime} 31^{\prime \prime} \mathrm{S} .$, long $170^{\circ} 34^{\prime} 58^{\prime \prime}$ W., 30 ft upstream from confluence with Televai stream and $0.2 \mathrm{mile}$ northwest of Amouli.

Drainage area.-- $<0.01 \mathrm{mi}^{2} \quad$ Tributary to.--Tuavaa Stream.

Type of site.--Miscellaneous site.

Period of record. --1971.

Low-Flow frequency. --None computed, drainage area outside applicable range for region 1 equations (table 6 and 7). Stream is not perennial at site.

Remarks. --Previously published as Tuavaa Stream No. 3

List of measurements: total of 1 .

Date Discharge $\left(\mathrm{ft}^{3} / \mathrm{s}\right)$

$\overline{01-05-71} \quad 0.09$ 
Table 4. Low-flow characteristics for miscellaneous sites on Tutuila, American Samoa--Continued

5. Tuavaa Stream at altitude 100 feet at Amouli.

Location. - Lat $14^{\circ} 16^{\prime} 32^{\prime \prime S ., ~ l o n g ~} 170^{\circ} 35^{\prime} 01^{\prime \prime W}$, , 400 ft upstream from confluence with Televai stream and 0.2 mile northwest of Amouli.

Drainage area. $--<0.01 \mathrm{mi}^{2} \quad$ Tributary to.--Televai stream.

Type of site.--Miscellaneous site.

Period of record. - -1971.

Low-flow frequency. --None computed, drainage area outside applicable range for region 1 equations (tables 6 and 7 ).

Remarks. --Previously published as Tuavaa Stream No. 1.

List of measurements: total of 1 .

Date Discharge $\left(\mathrm{ft}^{3} / \mathrm{s}\right)$

01-05-71 0.08 
Table 4. Low-flow characteristics for miscellaneous sites on Tutuila, American Samoa--Continued

6. Tuavaa Stream near mouth at Amouli.

Location. - Lat $14^{\circ} 16^{\prime} 32^{\prime \prime S ., ~ l o n g ~} 170^{\circ} 34^{\prime} 58^{\prime \prime} \mathrm{W} ., 200$ ft upstream from confluence with Televai stream and $0.2 \mathrm{mile}$ northwest of Amouli.

Drainage area. $-0.04 \mathrm{mi}^{2} \quad$ Tributary to.--Televai Stream.

Type of site.--Miscellaneous site.

Period of record.--1971.

\begin{tabular}{lcc}
\hline Streamflow & Discharge & Accuracy \\
characteristic & $\mathrm{ft}^{3} / \mathrm{s}$ & \% SE \\
\hline 7-day, 2-year low & 0.02 & 95.2 \\
7-day, 10-year low & 0.01 & 110 \\
Mean & 0.12 & 62.6 \\
Median & 0.05 & 66.5 \\
\hline
\end{tabular}

Basis of estimate.--Equations in table 6 .

Remarks. --Previously published as Tuavaa Stream No. 2. Single measurement is not base-flow, so equations in table 7 not used. For equations in table $6, \mathrm{GA}=80 \mathrm{ft}$ and $\mathrm{BR}=325 \mathrm{ft}$.

List of measurements: total of 1 .

$\frac{\text { Date }}{01-05-71} \frac{\text { Discharge }\left(\mathrm{ft}^{3} / \mathrm{s}\right)}{\mathrm{a} 0.26}$

a, includes surface runoff 
Table 4. Low-flow characteristics for miscellaneous sites on Tutuila, American Samoa--Continued

7. Fusiloa Stream at Amouli.

Location.--Lat $14^{\circ} 16^{\prime} 37^{\prime \prime S} .$, long 170 35'09"W., 800 ft upstream from confluence with Laloi Stream and 0.3 miles northwest of Amouli.

Drainage area. $--0.07 \mathrm{mi}^{2} \quad$ Tributary to.--Laloi stream.

Type of site.--Miscellaneous site.

Period of record. --1971.

\begin{tabular}{lcc}
\hline $\begin{array}{l}\text { Streamflow } \\
\text { characteristic }\end{array}$ & $\begin{array}{c}\text { Discharge } \\
\mathrm{ft}^{3} / \mathrm{s}\end{array}$ & $\begin{array}{c}\text { Accuracy } \\
\text { \%SE }\end{array}$ \\
\hline 7-day, 2-year low & 0.04 & 20.3 \\
7-day, 10-year low & 0.02 & 25.4 \\
Mean & 0.32 & 43.8 \\
Median & 0.13 & 21.8 \\
\hline
\end{tabular}

Basis of estimate.--Equations in table 7.

Remarks. --Base-flow index of 0.65 computed using station 16912000 as index station.

List of measurements: total of 1.

Date Discharge $\left(\mathrm{ft}^{3} / \mathrm{s}\right)$

$09-22-71 \quad 0.04$ 
Table 4. Low-flow characteristics for miscellaneous sites on Tutuila, American Samoa--Continued

\section{Lausaa stream at Vatia.}

Location.--Lat $14^{\circ} 15^{\prime} 30^{\prime \prime S ., ~ l o n g ~} 170^{\circ} 40 \cdot 25^{\prime \prime W} ., 1000$ ft upstream from Faatafe stream and 0.15 mile south of Vatia.

Drainage area.--0.17 $\mathrm{mi}^{2} \quad$ Tributary to.--Faatafe stream.

Type of site.--Miscellaneous site.

Period of record. --1972.

\begin{tabular}{lcc}
\hline $\begin{array}{l}\text { Streamflow } \\
\text { characteristic }\end{array}$ & $\begin{array}{c}\text { Discharge } \\
\mathrm{ft} / \mathrm{s}\end{array}$ & $\begin{array}{c}\text { Accuracy } \\
\text { \%SE }\end{array}$ \\
\hline 7-day, 2-year low & 0.05 & 20.3 \\
7-day, 10-year low & 0.02 & 25.4 \\
Mean & 0.51 & 43.8 \\
Median & 0.20 & 21.8 \\
\hline
\end{tabular}

Basis of estimate.--Equations in table 7 .

Remarks.--Base-flow index of 0.33 computed using station 16912000 as index station.

List of measurements: total of 1 .

$\frac{\text { Date }}{10-01-71} \quad \frac{\text { Discharge }\left(\mathrm{et}^{3} / \mathrm{s}\right)}{0.05}$ 
Table 4. Low-flow characteristics for miscellaneous sites on Tutuila, American Samoa--Continued

9. Vaipito Stream above Fitiuli stream at Pago Pago.

Location.--Lat $14^{\circ} 16^{\prime} 58^{\prime \prime} \mathrm{S} .$, long $170^{\circ} 42^{\prime} 18^{\prime \prime} \mathrm{W} ., 0.4$ mile upstream from mouth and 50 ft above confluence with Fitiuli stream (revision).

Drainage area.--Not computed. Tributary to.--Pago Pago Harbor.

Type of site.--Miscellaneous site.

Period of record. --1988.

Low-flow frequency.--None computed, municipal and domestic diversions upstream of site.

List of measurements: total of 1 .

Date Discharge $\left(\mathrm{ft}^{3} / \mathrm{s}\right)$

06-28-88 1.30

10. Vaipito Stream below Fitiuli stream at Pago Pago.

Location.--Lat $14^{\circ} 16^{\prime} 57^{\prime \prime S ., ~ l o n g ~} 170^{\circ} 42^{\prime} 17^{\prime \prime W}$, 0.4 mile upstream from mouth and 20 ft below confluence with Fitiuli stream.

Drainage area.--Not computed. Tributary to.--Pago Pago Harbor.

Type of site.--Miscellaneous site.

Period of record. --1963.

Low-flow frequency.--None computed, municipal and domestic diversions upstream of site.

List of measurements: total of 1 .

Date Discharge $\left(\mathrm{ft}^{3} / \mathrm{s}\right)$

05-17-63 c1.59

c, not previously published 
Table 4. Low-flow characteristics for miscellaneous sites on Tutuila, American Samoa--Continued

11. Vaipito Stream above Pago Stream at Pago Pago.

Location.--Lat $14^{\circ} 16^{\prime} 51^{\prime \prime} \mathrm{S} .$, long $170^{\circ} 42^{\prime} 15^{\prime \prime} \mathrm{W} ., 0.3$ mile upstream from mouth and 100 ft above confluence with Pago stream.

Drainage area.--Not computed. Tributary to.--Pago Pago Harbor.

Type of site.--Miscellaneous site.

Period of record. -1963 .

Low-flow frequency.--None computed, municipal and domestic diversions upstream of site.

List of measurements: total of 1 .

Date Discharge $\left(\mathrm{ft}^{3} / \mathrm{s}\right)$

$05-17-63 \quad$ c1.82

C, not previously published

12. Vaipito stream at altitude 20 feet at Pago Pago.

Location. - Lat $14^{\circ} 16^{\prime} 48^{\prime \prime} \mathrm{S} .$, long $170^{\circ} 42^{\prime} 14^{\prime} \mathrm{W} ., 100 \mathrm{ft}$ above pump house, $200 \mathrm{ft}$ below Pago stream, and 0.2 mile southwest of highway junction in Pago Pago.

Drainage area.--Not computed. Tributary to.--Pago Pago Harbor.

Type of site.--Miscellaneous site.

Period of record. - -1968.

Low-flow frequency.--None computed, municipal and domestic diversions upstream of site.

List of measurements: total of 1 .

$\frac{\text { Date }}{09-26-68} \quad \frac{\text { Discharge }\left(\mathrm{ft}^{3} / \mathrm{s}\right)}{0.82}$ 
Table 4. Low-flow characteristics for miscellaneous sites on Tutuila, American Samoa--Continued

13. Vaipito Stream below Pago stream at Pago Pago.

Location.--Lat $14^{\circ} 16^{\prime} 47^{\prime \prime} \mathrm{S} .$, long $170^{\circ} 42^{\prime} 14^{\prime \prime} \mathrm{W} ., 150$ ft below pump house, $450 \mathrm{ft}$ below Pago stream, and 0.2 mile southwest of highway junction in Pago Pago.

Drainage area.--Not computed. Tributary to.--Pago Pago Harbor.

Type of site.--Miscellaneous site.

Period of record.--1968.

Low-flow frequency.--None computed, municipal and domestic diversions upstream of site.

List of measurements: total of 1 .

Date Discharge $\left(\mathrm{ft}^{3} / \mathrm{s}\right)$

$09-26-68 \quad 0.40$

14. Vaipito Stream near highway bridge at Pago Pago.

Location.--Lat $14^{\circ} 16^{\prime} 44^{\prime \prime} \mathrm{S} .$, long $170^{\circ} 42^{\prime} 06^{\prime \prime} \mathrm{W} ., 600 \mathrm{ft}$ upstream from mouth and 100 ft above highway junction in Pago Pago.

Drainage area.--Not computed. Tributary to.--Pago Pago Harbor.

Type of site.--Miscellaneous site.

Period of record. --1963.

Low-flow frequency.--None computed, municipal and domestic diversions upstream of site.

List of measurements: total of 1 .

Date Discharge $\left(\mathrm{ft}^{3} / \mathrm{s}\right)$

05-17-63 c2.11

c, not previously published 
Table 4. Low-flow characteristics for miscellaneous sites on Tutuila, American Samoa--Continued

$$
\text { 15. Leau stream at Pago Pago. }
$$

Location.--Lat $14^{\circ} 17^{\prime} 09^{\prime \prime S}$., long $170^{\circ} 42^{\prime} 32^{\prime \prime} \mathrm{W} ., 10 \mathrm{ft}$ upstream from confluence with Vaipito stream and 1.8 miles west of Utulei High School.

Drainage area. $-0.03 \mathrm{mi}^{2} \quad$ Tributary to.--Vaipito stream.

Type of site.--Miscellaneous site.

Period of record.--1971.

\begin{tabular}{lcc}
\hline $\begin{array}{l}\text { Streamflow } \\
\text { characteristic }\end{array}$ & $\begin{array}{c}\text { Discharge } \\
\mathrm{ft}^{3} / \mathrm{s}\end{array}$ & $\begin{array}{c}\text { Accuracy } \\
\text { \%SE }\end{array}$ \\
\hline 7-day, 2-year low & 0.02 & 20.3 \\
7-day, 10-year low & 0.01 & 25.4 \\
Mean & 0.16 & 43.8 \\
Median & 0.06 & 21.8 \\
\hline
\end{tabular}

Basis of estimate.--Equations in table 7 .

Remarks.--Base-flow index of 0.70 computed using station 16912000 as index station.

List of measurements: total of 1 .

Date Discharge $\left(\mathrm{ft}^{3} / \mathrm{s}\right)$

08-09-71 0.06 
Table 4. Low-flow characteristics for miscellaneous sites on Tutuila, American Samoa--Continued

16. Right Branch Aga Stream at Pago Pago.

Location.--Lat $14^{\circ} 17^{\prime} 08^{\prime \prime S} .$, long $170^{\circ} 42^{\prime} 04^{\prime \prime W} ., 50$ ft upstream from confluence with Left Branch Aga Stream at altitude $210 \mathrm{ft}$ and 1.3 miles west of Utulei High School.

Drainage area.--0.05 $\mathrm{mi}^{2} \quad$ Tributary to.--Vaipito stream.

Type of site.--Miscellaneous site.

Period of record.--1967.

\begin{tabular}{lcc}
\hline Streamflow & Discharge & Accuracy \\
characteristic & $\mathrm{ft}^{3} / \mathrm{s}$ & $\frac{\mathrm{o} E}{8}$ \\
\hline 7-day, 2-year low & 0.01 & 20.3 \\
7-day, 10-year low & $<0.01$ & 25.4 \\
Mean & 0.09 & 43.8 \\
Median & 0.03 & 21.8 \\
\hline
\end{tabular}

Basis of estimate.--Equations in table 7 .

Remarks.--Base-flow index of 0.11 computed using station 16912000 as index station. Not previously published.

List of measurements: total of 1 .

$\frac{\text { Date }}{05-29-67} \quad \frac{\text { Discharge }\left(\mathrm{ft}^{3} / \mathrm{s}\right)}{\mathrm{c} 0.02}$

C, not previously published 
Table 4. Low-flow characteristics for miscellaneous sites on Tutuila, American Samoa--Continued

17. Left Branch Aga Stream at Pago Pago.

Location.--Lat $14^{\circ} 17^{\prime} 09^{\prime \prime S} .$, long $170^{\circ} 42^{\prime} 04^{\prime \prime W} ., 200$ ft upstream from confluence with Right Branch Aga Stream at altitude $240 \mathrm{ft}$ and 1.3 miles west of Utulei High School.

Drainage area.--0.11 $\mathrm{mi}^{2} \quad$ Tributary to.--Vaipito stream.

Type of site.--Miscellaneous site.

Period of record.--1967.

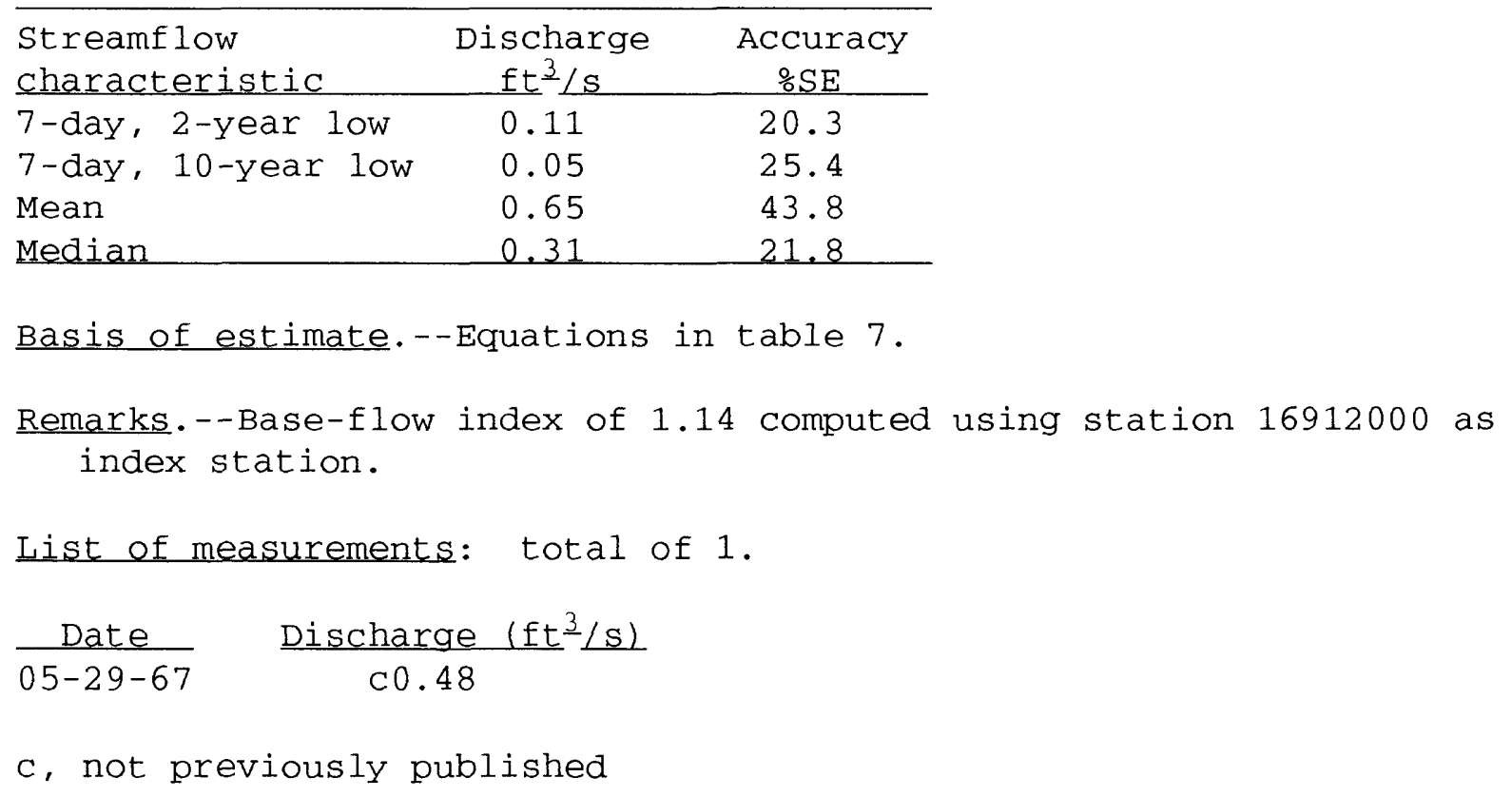


Table 4. Low-flow characteristics for miscellaneous sites on Tutuila, American Samoa--Continued

18. Aga Stream at Pago Pago.

Location.--Lat 14\%17'06"S., long $170^{\circ} 42^{\prime} 07^{\prime \prime} \mathrm{W}$. , at altitude $160 \mathrm{ft}$ and 1.3 miles west of Utulei High School.

Drainage area.--0.17 $\mathrm{mi}^{2} \quad$ Tributary to.--Vaipito stream.

Type of site.--Miscellaneous site.

Period of record. --1967.

\begin{tabular}{lcc}
\hline Streamflow & $\begin{array}{c}\text { Discharge } \\
\text { characteristic }\end{array}$ & $\begin{array}{c}\text { Accuracy } \\
\text { sSE }\end{array}$ \\
\hline 7-day, 2-year low & 0.15 & 20.3 \\
7-day, 10-year low & 0.07 & 25.4 \\
Mean & 0.91 & 43.8 \\
Median & 0.43 & 21.8 \\
\hline
\end{tabular}

Basis of estimate.--Equations in table 7.

Remarks.--Base-flow index of 1.03 computed using station 16912000 as index station.

List of measurements: total of 1 .

$\frac{\text { Date }}{05-29-67} \frac{\text { Discharge }\left(\mathrm{ft}^{3} / \mathrm{s}\right)}{\mathrm{c} 0.67}$

C, not previously published 
Table 4. Low-flow characteristics for miscellaneous sites on Tutuila, American Samoa--Continued

19. Fitiuli Stream above Aga Stream at Pago Pago.

Location. - - Lat $14^{\circ} 17^{\prime} 04^{\prime \prime} \mathrm{S} .$, long $170^{\circ} 42^{\prime} 12^{\prime \prime} \mathrm{W} ., 10$ ft upstream from confluence with Aga Stream and 1.4 miles west of utulei High School.

Drainage area.--0.05 $\mathrm{mi}^{2}$ Tributary to.--Vaipito stream.

Type of site.--Miscellaneous site.

Period of record. --1971.

\begin{tabular}{lcc}
\hline $\begin{array}{l}\text { Streamflow } \\
\text { characteristic }\end{array}$ & $\begin{array}{c}\text { Discharge } \\
\mathrm{ft}^{3} / \mathrm{s}\end{array}$ & $\begin{array}{c}\text { Accuracy } \\
\text { \%SE }\end{array}$ \\
\hline 7-day, 2-year low & 0.08 & 24.3 \\
7-day, 10-year low & 0.04 & 30.6 \\
Mean & 0.41 & 44.0 \\
Median & 0.20 & 22.4 \\
\hline
\end{tabular}

Basis of estimate.--Equations in table 7 .

Remarks.--Base-flow index of 1.82 computed using station 16912000 as index station.

List of measurements: total of 1 .

$\frac{\text { Date }}{08-09-71} \frac{\text { Discharge }\left(\mathrm{ft}^{3} / \mathrm{s}\right)}{\mathrm{c} 0.26}$

c, not previously published 
Table 4. Low-flow characteristics for miscellaneous sites on Tutuila, American Samoa--Continued

20. Fitiuli Stream below Aga Stream at Pago Pago.

Location.--Lat $14^{\circ} 17^{\prime} 03^{\prime \prime S} .$, long $170^{\circ} 42^{\prime} 16^{\prime \prime W}$., 500 ft upstream from confluence with Vaipito Stream and 1.4 miles west of utulei High School.

Drainage area. $-0.26 \mathrm{mi}^{2} \quad$ Tributary to.--Vaipito Stream.

Type of site.--Miscellaneous site.

Period of record.--1969, 1988.

\begin{tabular}{lcc}
\hline $\begin{array}{l}\text { Streamflow } \\
\text { characteristic }\end{array}$ & $\begin{array}{c}\text { Discharge } \\
\mathrm{ft}^{3} / \mathrm{s}\end{array}$ & $\begin{array}{c}\text { Accuracy } \\
\text { \%SE }\end{array}$ \\
\hline 7-day, 2-year low & 0.20 & 20.3 \\
7-day, 10-year low & 0.09 & 25.4 \\
Mean & 1.28 & 43.8 \\
Median & 0.61 & 21.8 \\
\hline
\end{tabular}

Basis of estimate.--Equations in table 7 .

Remarks.--Base-flow index of 0.94 computed using station 16912000 as index station and 6-28-88 measurement.

List of measurements: total of 2 .

$\frac{\text { Date }}{05-27-69} \quad \frac{\text { Discharge }\left(\mathrm{ft}^{3} / \mathrm{s}\right)}{\mathrm{c} 0.61} \quad \frac{\text { Date }}{06-28-88} \quad \frac{\text { Discharge }\left(\mathrm{ft}^{3} / \mathrm{s}\right)}{\mathrm{c} 0.36}$

C, not previously published 
Table 4. Low-flow characteristics for miscellaneous sites on Tutuila, American Samoa--Continued

21. Fitiuli Stream above Vaipito stream at Pago Pago.

Location.--Lat $14^{\circ} 16^{\prime} 59^{\prime \prime S} .$, long $170^{\circ} 42^{\prime} 17^{\prime \prime W} ., 100$ ft upstream from confluence with Vaipito Stream, 0.5 mile southeast of Pago Pago Harbor and 0.55 mile west of Mt. Sione (revision).

Drainage area.--0.27 $\mathrm{mi}^{2} \quad$ Tributary to.--Vaipito Stream.

Type of site.--Miscellaneous site.

Period of record. -1988 .

\begin{tabular}{lcc}
\hline Streamflow & $\begin{array}{c}\text { Discharge } \\
\text { characteristic }\end{array}$ & $\begin{array}{c}\text { Accuracy } \\
\text { \% }\end{array}$ \\
\hline 7-day, 2-year low & 0.24 & 20.3 \\
7-day, 10-year low & 0.11 & 25.4 \\
Mean & 1.42 & 43.8 \\
Median & 0.70 & 21.8 \\
\hline
\end{tabular}

Basis of estimate.--Equations in table 7 .

Remarks.--Base-flow index of 1.08 computed using station 16912000 as index station and 6-28-88 measurement.

List of measurements: total of 2 .

$\frac{\text { Date }}{06-28-88} \quad \frac{\text { Discharge }\left(\mathrm{ft}^{3} / \mathrm{s}\right)}{0.43} \quad \frac{\text { Date }}{07-13-88} \quad \frac{\text { Discharge (ft } 3 \text { ) }}{0.49}$ 
Table 4. Low-flow characteristics for miscellaneous sites on Tutuila, American Samoa--Continued

\section{Pago stream at Pago Pago.}

Location. --Lat $14^{\circ} 16^{\prime} 50 \mathrm{M}$., long $170^{\circ} 42 \cdot 15^{\prime \prime} \mathrm{W} ., 60 \mathrm{ft}$ upstream from confluence with Vaipito Stream, 0.3 mile southeast of Pago Pago Harbor and 1.5 mile west of Utulei High School.

Drainage area.--0.11 $\mathrm{mi}^{2} \quad$ Tributary to.--Vaipito stream.

Type of site.-Miscellaneous site.

Period of record. -1963 .

\begin{tabular}{lcc}
\hline $\begin{array}{l}\text { Streamflow } \\
\text { characteristic }\end{array}$ & $\begin{array}{c}\text { Discharge } \\
\mathrm{ft}^{3} / \mathrm{s}\end{array}$ & $\begin{array}{c}\text { Accuracy } \\
\text { o.SE }\end{array}$ \\
7-day, 2-year low & 0.03 & 20.3 \\
7-day, 10-year low & 0.01 & 25.4 \\
Mean & 0.30 & 43.8 \\
Median & 0.11 & 21.8 \\
\hline
\end{tabular}

Basis of estimate.--Equations in table 7 .

Remarks.--Base-flow index of 0.25 computed using station 16912000 as index station.

List of measurements: total of 1 .

Date Discharge $\left(\mathrm{ft}^{3} / \mathrm{s}\right)$

05-17-63 c0.08

C, not previously published 
Table 4. Low-flow characteristics for miscellaneous sites on Tutuila, American Samoa--Continued

23. Utumoa Stream at altitude $400 \mathrm{ft}$.

Location.--Lat $14^{\circ} 17^{\prime} 30^{\prime \prime S} .$, long $170^{\circ} 42^{\prime} 20^{\prime \prime} \mathrm{W} ., 0.50$ mile upstream from confluence of Vaipito stream and 0.37 mile northwest of Fagaalu Reservoir.

Drainage area.--0.12 $\mathrm{mi}^{2} \quad$ Tributary to.--Vaipito stream.

Type of site.--Miscellaneous site.

Period of record. --1989-90.

Low-flow frequency.--None computed, municipal diversion upstream of site.

List of measurements: total of 3 .

$\begin{array}{cccc}\frac{\text { Date }}{05-24-89} & \frac{\text { Discharge }\left(\mathrm{ft}^{3} / \mathrm{s}\right)}{\mathrm{c} 0.15} & \frac{\text { Date }}{08-23-90} & \left.\frac{\text { Discharge }\left(\mathrm{ft}^{3}\right.}{\mathrm{c}} / \mathrm{s}\right) \\ 08-23-89 & \mathrm{c} 0.06 & 0.09\end{array}$

C, not previously published 
Table 4. Low-flow characteristics for miscellaneous sites on Tutuila, American Samoa--Continued

24. Utumoa Stream at altitude $380 \mathrm{ft}$.

Location.--Lat $14^{\circ} 17 \cdot 27 \mathrm{M} .$, long $170^{\circ} 42 \cdot 21^{\prime \prime} \mathrm{W} ., 0.45$ mile upstream from confluence of Vaipito Stream and 0.44 mile northwest of Fagaalu Reservoir.

Drainage area.--0.14 $\mathrm{mi}^{2} \quad$ Tributary to.--Vaipito stream.

Type of site.--Miscellaneous site.

Period of record.--1989-90.

Low-flow frequency.--None computed, municipal diversion upstream of site.

List of measurements: total of 3 .

$\begin{array}{cccc}\frac{\text { Date }}{05-24-89} & \frac{\text { Discharge }\left(\mathrm{ft}^{3} / \mathrm{s}\right)}{\mathrm{c} 0.20} & \frac{\text { Date }}{08-23-90} & \frac{\text { Discharge }\left(\mathrm{ft}^{3} / \mathrm{s}\right)}{\mathrm{c} 0.07} \\ 08-23-89 & \mathrm{c} 0.12 & & \end{array}$

c, not previously published 
Table 4. Low-flow characteristics for miscellaneous sites on Tutuila, American Samoa--Continued

25. Fagaalu stream above Virgin Pool.

Location.--Lat $14^{\circ} 17^{\prime} 35^{\prime \prime S} .$, long $170^{\circ} 41^{\prime} 48^{\prime \prime W}$., 500 ft upstream from Virgin Pool and 1.1 mile southwest of Utulei High School.

Drainage area.--Not computed. Tributary to.--Pacific Ocean.

Type of site.--Miscellaneous site.

Period of record. --1963, 1968.

Low-flow frequency.--None computed, municipal diversion upstream of site.

List of measurements: total of 2 .

$\frac{\text { Date }}{05-15-63} \quad \frac{\text { Discharge }\left(\mathrm{ft}^{3} / \mathrm{s}\right)}{\mathrm{c} 0.33} \quad \frac{\text { Date }}{10-01-68} \quad \frac{\text { Discharge }\left(\mathrm{ft}^{3} / \mathrm{s}\right)}{\mathrm{c} 0.05}$

C, not previously published

26. Fagaalu Stream 200 ft below Virgin Pool.

Location.--Lat $14^{\circ} 17 \cdot 34 \mathrm{MS}$, , long $170^{\circ} 41^{\prime} 41^{\prime \prime W}$., 200 ft downstream from Virgin pool and 1.0 mile southwest of utulei High School.

Drainage area.--Not computed. Tributary to.--Pacific Ocean.

Type of site.--Miscellaneous site.

Period of record.--1967-68.

Low-flow frequency.--None computed, municipal diversion upstream of site.

List of measurements: total of 2 .

$\frac{\text { Date }}{05-28-67} \quad \frac{\text { Discharge }\left(\mathrm{ft}^{3} / \mathrm{s}\right)}{\mathrm{c} 0.64} \quad \frac{\text { Date }}{10-01-68} \quad \frac{\text { Discharge }\left(\mathrm{ft}^{3} / \mathrm{s}\right)}{\mathrm{c} 0.06}$

C, not previously published 
Table 4. Low-flow characteristics for miscellaneous sites on Tutuila, American Samoa--Continued

27. Fagaalu stream 700 ft below Virgin Pool.

Location.--Lat $14^{\circ} 17 \cdot 35^{\mathrm{NS} .}$, long $170^{\circ} 41 \cdot 38^{\mathrm{NW}} \mathrm{W}, 700$ ft upstream from Virgin Pool at altitiude $360 \mathrm{ft}$ and $1.0 \mathrm{mile}$ southwest of Utulei High School.

Drainage area.--Not computed. Tributary to.--Pacific Ocean.

Type of site.--Miscellaneous site.

Period of record. --1963.

Low-flow frequency.--None computed, municipal diversion upstream of site.

List of measurements: total of 1 .

Date Discharge $\left(\mathrm{ft}^{3} / \mathrm{s}\right)$

05-15-63 c0.55

C, not previously published

28. Fagaalu Stream 1,200 ft below Virgin Pool.

Location.--Lat $14^{\circ} 17 \cdot 37 \mathrm{~m}$., long $170^{\circ} 41 \cdot 36^{\prime \prime W} ., 1,200$ ft downstream from Virgin Pool and 0.8 mile upstream from mouth.

Drainage area.--Not computed. Tributary to.--Pacific Ocean.

Type of site.--Miscellaneous site.

Period of record. -1963 .

Low-flow Erequency.--None computed, municipal diversion upstream of site.

List of measurements: total of 1 .

Date Discharge $\left(\mathrm{ft}^{3} / \mathrm{s}\right)$

05-15-63 C0.78

c, not previously published 
Table 4. Low-flow characteristics for miscellaneous sites on Tutuila, American Samoa--Continued

29. Fagaalu Stream below Station 16949500.

Location. - Lat $14^{\circ} 17^{\prime} 40^{\prime \prime S} .$, long $170^{\circ} 41$ '18"W., 400 ft downstream from Station 16949500 at altitude $120 \mathrm{ft}$ and 0.4 mile upstream from mouth.

Drainage area.--Not computed. Tributary to.--Pacific Ocean.

Type of site.--Miscellaneous site.

Period of record. -1963 .

Low-flow frequency.--None computed, municipal diversion upstream of site.

List of measurements: total of 1 .

Date Discharge $\left(\mathrm{ft}^{3} / \mathrm{s}\right)$

05-15-63 c0.93

c, not previously published

30. Fagaalu Stream 450 ft above mouth at Fagaalu.

Location.--Lat $14^{\circ} 17^{\prime} 47^{\prime \prime S}$, long $170^{\circ} 41^{\prime} 00^{\prime \prime}$ W., 450 ft above mouth at Fagaalu.

Drainage area.--Not computed. Tributary to.--Pacific Ocean.

Type of site.--Miscellaneous site.

Period of record. --1966.

Low-flow frequency.--None computed, municipal and domestic diversions upstream of site.

Remarks.--Previously published as Fagaalu stream No. 1 at Fagaalu

List of measurements: total of 1 .

Date Discharge $\left(\mathrm{ft}^{3} / \mathrm{s}\right)$

06-19-66 5.32 
Table 4. Low-flow characteristics for miscellaneous sites on Tutuila, American Samoa--Continued

31. Fagaalu Stream 350 ft above mouth at Fagaalu.

Location.--Lat $14^{\circ} 17^{\prime} 47^{\prime \prime S ., ~ l o n g ~} 170^{\circ} 40^{\prime} 59^{\prime \prime} \mathrm{W} ., 350$ ft above mouth at Fagaalu.

Drainage area.--Not computed. Tributary to.--Pacific Ocean.

Type of site.--Miscellaneous site.

Period of record. - -1966.

Low-flow frequency.--None computed, municipal and domestic diversions upstream of site.

Remarks.--Previously published as Fagaalu Stream No. 2 at Fagaalu.

List of measurements: total of 1 .

Date Discharge $\left(\mathrm{ft}^{3} / \mathrm{s}\right)$

$\overline{06-19-66} \quad \frac{1.53}{4.61}$

32. Fagaalu Stream 200 ft above mouth at Fagaalu.

Location.--Lat $14^{\circ} 17^{\prime} 47^{\prime \prime S}$, long $170^{\circ} 40 \cdot 57 \mathrm{~W} ., 200$ ft above mouth at Fagaalu.

Drainage area.--Not computed. Tributary to.--Pacific Ocean.

Type of site.--Miscellaneous site.

Period of record. --1966 .

Low-flow frequency.--None computed, municipal and domestic diversions upstream of site.

Remarks.--Previously published as Fagaalu Stream No. 3 at Fagaalu.

List of measurements: total of 1 .

$\frac{\text { Date }}{06-19-66} \quad$ Discharge $\left(\mathrm{ft}^{3} / \mathrm{s}\right)$

06-19-66 4.89 
Table 4. Low-flow characteristics for miscellaneous sites on Tutuila, American Samoa--Continued

33. Afuelo Stream above station 16948000 .

Location.--Lat $14^{\circ} 18^{\prime} 06^{\prime \prime S ., ~ l o n g ~} 170^{\circ} 41^{\prime} 08^{\prime \prime W} ., 20$ ft above village intake system, $100 \mathrm{ft}$ upstream of gaging station $16948000,0.2 \mathrm{mile}$ northwest of Matuu, and 0.3 mile upstream from mouth (revision).

Drainage area.--0.24 $\mathrm{mi}^{2} \quad$ Tributary to.--Pacific Ocean.

Type of site.--Miscellaneous site.

Period of record.--1983, 1987, 1989-90.

\begin{tabular}{lcc}
\hline Streamflow & $\begin{array}{c}\text { Discharge } \\
\mathrm{ft}^{3} / \mathrm{S}\end{array}$ & $\begin{array}{c}\text { Accuracy } \\
\text { characteristic }\end{array}$ \\
\hline 7-day, 2-year low & 0.06 & 20.3 \\
7-day, 10-year low & 0.02 & 25.4 \\
Mean & 1.48 & 43.8 \\
Median & 0.63 & 21.8 \\
\hline
\end{tabular}

Basis of estimate.--Equations in table 7, with the mean and median flow estimates being adjusted to correspond to the pre-diversion mean and median flow at 16948000 .

Remarks.--Base-flow index of 0.29 computed using station 16948000 as index station with the 10-26-82 streamflow measurement.

List of measurements: total of 6 .

\begin{tabular}{|c|c|c|c|}
\hline Date & Discharge $\left(\mathrm{ft}^{3} / \mathrm{s}\right)$ & Date & Discharge $\left(\mathrm{ft}^{3} / \mathrm{s}\right)$ \\
\hline $10-26-82$ & 0.08 & $07-30-87$ & $\mathrm{~g} 0.02$ \\
\hline $07-13-83$ & 0.09 & $08-16-89$ & 0.09 \\
\hline $08-18-83$ & 0.07 & $08-07-90$ & $\mathrm{~g} 0.02$ \\
\hline
\end{tabular}

g, measurement made below diversion 
Table 4. Low-flow characteristics for miscellaneous sites on Tutuila, American Samoa--Continued

34. Puna Stream tributary at Mapusagafou.

Location.--Lat $14^{\circ} 19^{\prime} 17^{\prime \prime S}$., long $170^{\circ} 44^{\prime} 56^{\prime \prime} \mathrm{W}$, , at mouth of confluence with Puna Stream, 0.6 mile northwest of Mapusaga High School, and 1.2 miles east of Aoloaufou School (revision).

Drainage area. - $<0.01 \mathrm{mi}^{2} \quad$ Tributary to.--Puna Stream.

Type of site.--Miscellaneous site.

Period of record.--1971.

Low-flow frequency. - -No estimates made, drainage area outside of applicable limits. Stream is not perennial at site.

Remarks.--Stream goes dry during the dry season.

List of measurements: total of 1 .

Date Discharge $\left(\mathrm{ft}^{3} / \mathrm{s}\right)$

03-08-71 b0.22

b, revision 
Table 4. Low-flow characteristics for miscellaneous sites on Tutuila, American Samoa--Continued

35. Puna Stream at Mapusagafou.

Location.--Lat $14^{\circ} 19^{\prime} 17 \mathrm{M}$., long $170^{\circ} 44^{\prime} 56^{\prime \prime W} ., 700$ ft upstream from confluence with Leaveave stream and 0.7 mile northeast of Mapusagafou (revision).

Drainage area.--0.08 $\mathrm{mi}^{2}$ Tributary to.--Leaveave Stream.

Type of site.--Miscellaneous site.

Period of record.--1971.

\begin{tabular}{lcc}
\hline $\begin{array}{l}\text { Streamflow } \\
\text { characteristic }\end{array}$ & $\begin{array}{c}\text { Discharge } \\
\mathrm{ft}^{3} / \mathrm{s}\end{array}$ & $\begin{array}{c}\text { Accuracy } \\
\text { \%SE }\end{array}$ \\
\hline 7-day, 2-year low & 0.09 & 13.7 \\
7-day, 10-year low & 0.04 & 13.3 \\
Mean & 0.46 & 35.2 \\
Median & 0.28 & 21.6 \\
\hline
\end{tabular}

Basis of estimate.--Equations in table 9.

Remarks.--Base-flow index of 1.27 computed using station 16920500 as index station with the 8-2-71 streamflow measurement. Basin slope is $4,260 \mathrm{ft} / \mathrm{mile}$.

List of measurements: total of 2 .

$\left.\frac{\text { Date }}{03-08-71} \quad \frac{\text { Discharge }\left(\mathrm{ft}^{3} / \mathrm{s}\right)}{0.33} \quad \frac{\text { Date }}{08-02-71} \quad \frac{\text { Discharge (ft }}{0.08} / \mathrm{s}\right)$


Table 4. Low-flow characteristics for miscellaneous sites on Tutuila, American Samoa--Continued

\section{Leaveave Stream.}

Location.--Lat $14^{\circ} 19^{\prime} 16^{\prime \prime S} .$, long $170^{\circ} 44 \cdot 58^{\prime \prime W} ., 25$ ft downstream of confluence with Puna Stream, 0.7 mile northwest of Mapusaga High School and 1.2 miles east of Aoloaufou School (revision).

Drainage area.--0.25 $\mathrm{mi}^{2} \quad$ Tributary to. - -N/A.

Type of site.--Miscellaneous site.

Period of record. - - 1971 .

\begin{tabular}{lcc}
\hline $\begin{array}{l}\text { Streamflow } \\
\text { characteristic }\end{array}$ & $\begin{array}{c}\text { Discharge } \\
\mathrm{ft}^{3} / \mathrm{s}\end{array}$ & $\begin{array}{c}\text { Accuracy } \\
\text { o.SE }\end{array}$ \\
\hline 7-day, 2-year low & 0.19 & 13.7 \\
7-day, 10-year low & 0.08 & 13.3 \\
Mean & 1.23 & 35.2 \\
Median & 0.70 & 21.6 \\
\hline
\end{tabular}

Basis of estimate.--Equations in table 9.

Remarks. --Base-flow index of 0.80 computed using station 16920500 as index station. Basin slope is $3,630 \mathrm{ft} / \mathrm{mile}$.

Remarks. - -

List of measurements: total of 1 .

Date Discharge $\left(\mathrm{Et}^{3} / \mathrm{s}\right)$

08-18-71 0.11 
Table 4. Low-flow characteristics for miscellaneous sites on Tutuila, American Samoa--Continued

37. Tafeta stream.

Location.--Lat $14^{\circ} 19^{\prime} 12^{\prime \prime S ., ~ l o n g ~} 170^{\circ} 45^{\prime} 08^{\prime \prime W}, 0^{\prime} 0.2$ mile upstream from confluence with Leaveave Stream and 0.6 mile north of Mapusagafou.

Drainage area.--0.09 $\mathrm{mi}^{2}$. Tributary to.--Leaveave Stream.

Type of site.--Miscellaneous site.

Period of record. --1971.

Low-flow frequency. --None computed. Stream is not shown on USGS Tutuila topographic map. Unknown if stream is perennial.

List of measurements: total of 1 .

Date Discharge $\left(\mathrm{ft}^{3} / \mathrm{s}\right)$

$08-18-71 \quad 0.08$

38. Leafu Stream at altitude $160 \mathrm{ft}$ at Leone.

Location.--Lat $14^{\circ} 19^{\prime} 49^{\prime} \mathrm{S} .$, long $170^{\circ} 46^{\prime} 55^{\prime \prime W} ., 0.9$ mile north of St. Theresa Girl's School at Leone and 1.4 mile northeast of Atauloma School at Afao (revision).

Drainage area.--Not computed. Tributary to.--Pacific Ocean

Type of site.--Miscellaneous site.

Period of record.--1971.

Low-flow frequency.--None computed. Municipal diversion upstream of site.

List of measurements: total of 1 .

Date Discharge $\left(\mathrm{ft}^{3} / \mathrm{s}\right)$

$08-05-71 \quad 0.58$ 
Table 4. Low-flow characteristics for miscellaneous sites on Tutuila, American Samoa--Continued

39. Leafu stream at altitude $360 \mathrm{ft}$ near Leone.

Location.--Lat $14^{\circ} 19^{\prime} 38^{\prime \prime} \mathrm{S} .$, long $170^{\circ} 46^{\prime} 56^{\prime \prime} \mathrm{W} ., 900$ ft above village catchment, 800 ft above partial-record station 16934000 , and 1.2 miles northeast of Leone (revision).

Drainage area.--0.66 $\mathrm{mi}^{2} \quad$ Tributary to.--Pacific Ocean.

Type of site.--Miscellaneous site.

Period of record.--1969, 1977-78.

\begin{tabular}{lcc}
\hline $\begin{array}{l}\text { Streamflow } \\
\text { characteristic }\end{array}$ & $\begin{array}{c}\text { Discharge } \\
\mathrm{ft}^{3} / \mathrm{s}\end{array}$ & $\begin{array}{c}\text { Accuracy } \\
\text { \%SE }\end{array}$ \\
\hline 7-day, 2-year low & 0.78 & 13.7 \\
7-day, 10-year low & 0.35 & 13.3 \\
Mean & 4.23 & 35.2 \\
Median & 2.67 & 21.6 \\
\hline
\end{tabular}

Basis of estimate.--Equations in table 9 .

Remarks.--Base-flow index of 1.80 computed using an average from stations 16920500 and 16931000 as index stations with the 7-12-78 streamflow measurement. Basin slope is 4,970 $\mathrm{ft} / \mathrm{mile}$.

List of measurements: total of 5 .

$\begin{array}{cccc}\text { Date } & \text { Discharge }\left(\mathrm{ft}^{3} / \mathrm{s}\right) & \text { Date } & \text { Discharge }\left(\mathrm{ft}^{3} / \mathrm{s}\right) \\ 05-24-69 & \mathrm{ca} 3.73 & 07-12-78 & \mathrm{c} 0.88 \\ 07-13-77 & \mathrm{e} 2.85 & 07-19-78 & \mathrm{c} 0.81 \\ 08-19-77 & 0.66 & & \end{array}$

a, includes surface runoff

c, not previously published

e, may include surface runoff 
Table 4. Low-flow characteristics for miscellaneous sites on Tutuila, American Samoa--Continued

40. Leafu Stream above 2nd unnamed tributary to Leafu stream.

Location. - - Lat $14^{\circ} 19^{\prime} 35^{\prime \prime S ., ~ l o n g ~} 170^{\circ} 46^{\prime} 54 " \mathrm{~W} ., 1,100$ ft above village catchment at altitude $365 \mathrm{ft}$ and 1.3 miles northeast of Leone (revision).

Drainage area. $-0.50 \mathrm{mi}^{2} \quad$ Tributary to.--Pacific Ocean.

Type of site.--Miscellaneous site.

Period of record.--1977, 1981-83, 1987, 1989-90.

\begin{tabular}{lcc}
\hline $\begin{array}{l}\text { Streamflow } \\
\text { characteristic }\end{array}$ & $\begin{array}{c}\text { Discharge } \\
\mathrm{ft}^{3} / \mathrm{s}\end{array}$ & $\begin{array}{c}\text { Accuracy } \\
\text { oSE }\end{array}$ \\
\hline 7-day, 2-year low & 0.70 & 22.7 \\
7-day, 10-year low & 0.26 & 44.9 \\
Mean & 5.80 & 61.9 \\
Median & 2.70 & 39.1 \\
\hline
\end{tabular}

Basis of estimate.--Graphical correlation with station 16931000 .

Remarks.--Site used in regression analysis.

List of measurements: total of 11 .

\begin{tabular}{|c|c|c|c|}
\hline Date & Discharge $\left(\mathrm{ft}^{3} / \mathrm{s}\right)$ & Date & Discharge $\left(\mathrm{ft}^{3} / \mathrm{s}\right)$ \\
\hline $07-13-77$ & be 2.34 & $08-09-83$ & 0.44 \\
\hline $08-19-77$ & 0.10 & $06-02-87$ & 0.86 \\
\hline $08-03-81$ & be 4.18 & $09-02-87$ & 1.02 \\
\hline $10-01-81$ & b1. 57 & $08-15-89$ & 0.85 \\
\hline $04-20-82$ & 1.27 & $08-07-90$ & 0.60 \\
\hline $07-14-83$ & 0.63 & & \\
\hline
\end{tabular}


Table 4. Low-flow characteristics for miscellaneous sites on Tutuila, American Samoa--Continued

41. 2nd unnamed tributary to Leafu stream.

Location.--Lat $14^{\circ} 19^{\prime} 35^{\prime \prime S ., ~ l o n g ~} 170^{\circ} 46^{\prime} 57^{\prime \prime W} ., 300 \mathrm{ft}$ above confluence with Leafu stream at altitude $390 \mathrm{ft}$ and 1.3 miles northeast of Leone.

Drainage area.--0.14 $\mathrm{mi}^{2} \quad$ Tributary to.--Leafu stream.

Type of site.--Miscellaneous site.

Period of record.--1977, 1983.

\begin{tabular}{lcc}
\hline $\begin{array}{l}\text { Streamflow } \\
\text { characteristic }\end{array}$ & $\begin{array}{c}\text { Discharge } \\
\mathrm{ft}^{3} / \mathrm{s}\end{array}$ & $\begin{array}{c}\text { Accuracy } \\
\text { \%SE }\end{array}$ \\
\hline 7-day, 2-year low & 0.15 & 13.7 \\
7-day, 10-year low & 0.06 & 13.3 \\
Mean & 0.79 & 35.2 \\
Median & 0.48 & 21.6 \\
\hline
\end{tabular}

Basis of estimate.--Equations in table 9.

Remarks. --Base-flow index of 1.21 computed using an average from stations 16920500 and 16931000 as index stations with the 8-9-83 streamflow measurement. Basin slope is 4,100 ft/mile.

List of measurements: total of 3 .

$\begin{array}{cccc}\frac{\text { Date }}{07-13-77} & \frac{\text { Discharge }\left(\mathrm{ft}^{3} / \mathrm{s}\right)}{0.50} & \frac{\text { Date }}{08-09-83} & \frac{\text { Discharge }\left(\mathrm{ft}^{3} / \mathrm{s}\right)}{0.07} \\ 08-19-77 & 0.53 & \end{array}$


Table 4. Low-flow characteristics for miscellaneous sites on Tutuila, American Samoa--Continued

42. Leafu Stream below 1st unnamed tributary near Leone.

Location.--Lat $14^{\circ} 19^{\prime} 33^{\prime \prime S ., ~ l o n g ~} 170^{\circ} 46^{\prime} 52^{\prime \prime W} ., 1,500$ ft upstream of village catchment and 1.3 miles northeast of Leone.

Drainage area.--0.48 $\mathrm{mi}^{2} \quad$ Tributary to.--Pacific Ocean.

Type of site.--Miscellaneous site.

Period of record.--1977-78.

\begin{tabular}{lcc}
\hline $\begin{array}{l}\text { Streamflow } \\
\text { characteristic }\end{array}$ & $\begin{array}{c}\text { Discharge } \\
\mathrm{ft} / \mathrm{s}\end{array}$ & $\begin{array}{c}\text { Accuracy } \\
\text { \%SE }\end{array}$ \\
\hline 7-day, 2-year low & 0.63 & 13.7 \\
7-day, 10-year low & 0.29 & 13.3 \\
Mean & 3.15 & 35.2 \\
Median & 2.05 & 21.6 \\
\hline
\end{tabular}

Basis of estimate.--Equations in table 9.

Remarks. - Base-flow index of 2.12 computed using an average from stations 16920500 and 16931000 as index stations with the 7-12-78 streamflow measurement. Basin slope is $4,810 \mathrm{ft} / \mathrm{mile}$.

List of measurements: total of 4 .

$\begin{array}{cccc}\frac{\text { Date }}{07-13-77} & \text { Discharge }\left(\mathrm{ft}^{3} / \mathrm{s}\right) & \frac{\text { Date }}{07-12-78} & \frac{\text { Discharge }\left(\mathrm{ft}^{3} / \mathrm{s}\right)}{\mathrm{be1} .56} \\ 08-19-77 & 0.32 & 07-19-78 & \mathrm{c} 0.55\end{array}$

b, revision

c, not previously published

e, may include surface runoff 
Table 4. Low-flow characteristics for miscellaneous sites on Tutuila, American Samoa--Continued

43. 1st unnamed tributary to Leafu Stream near Leone.

Location.--Lat $14^{\circ} 19 \cdot 31^{\prime \prime S} .$, long $170^{\circ} 46^{\prime} 52^{\prime \prime} \mathrm{W} ., 0.2 \mathrm{mile}$ above village catchment and 1.3 miles northeast of Leone (revision).

Drainage area.--0.14 $\mathrm{mi}^{2} \quad$ Tributary to.--Pacific Ocean.

Type of site.--Miscellaneous site.

Period of record.--1977-78.

\begin{tabular}{lcc}
\hline $\begin{array}{l}\text { Streamflow } \\
\text { characteristic }\end{array}$ & $\begin{array}{c}\text { Discharge } \\
\mathrm{ft}^{3} / \mathrm{s}\end{array}$ & $\begin{array}{c}\text { Accuracy } \\
\text { \%SE }\end{array}$ \\
\hline 7-day, 2-year low & 0.13 & 11.9 \\
7-day, 10-year low & 0.06 & 23.4 \\
Mean & 0.70 & 9.3 \\
Median & 0.49 & 8.6 \\
\hline
\end{tabular}

Basis of estimate.--Graphical correlation with station 16920500 .

Remarks.--Site used in regional regression analysis.

List of measurements: total of 21 .

\begin{tabular}{|c|c|c|c|}
\hline Date & Discharge $\left(\mathrm{ft}^{3} / \mathrm{s}\right)$ & Date & Discharge $\left(\mathrm{ft}^{3} / \mathrm{s}\right)$ \\
\hline $07-13-77$ & f0. 10 & $06-30-78$ & $\mathrm{c} 0.18$ \\
\hline $08-19-77$ & 0.01 & $07-12-78$ & c 0.11 \\
\hline $01-11-78$ & $\operatorname{acl} 1.26$ & $07-19-78$ & c0.11 \\
\hline $02-08-78$ & $\operatorname{ac} 1.23$ & $08-14-78$ & $\operatorname{ac} 1.28$ \\
\hline $03-07-78$ & $\mathrm{c} 0.26$ & $09-11-78$ & $\mathrm{c} 0.43$ \\
\hline $03-31-78$ & $\mathrm{ac} 1.14$ & $09-18-78$ & $c 0.36$ \\
\hline $04-26-78$ & $\mathrm{c} 0.32$ & $09-26-78$ & $\mathrm{c} 0.28$ \\
\hline $05-03-78$ & $\mathrm{c} 0.94$ & $10-02-78$ & $\mathrm{c} 0.18$ \\
\hline $05-10-78$ & $\operatorname{ac} 0.96$ & $10-16-78$ & $c 0.60$ \\
\hline $06-07-78$ & $\mathrm{C} 0.37$ & $11-06-78$ & $\mathrm{c} 0.79$ \\
\hline $06-26-78$ & C0.25 & & \\
\hline
\end{tabular}

a, includes surface runoff

c, not previously published

$f$, surface runoff at index station on this data 
Table 4. Low-flow characteristics for miscellaneous sites on Tutuila, American Samoa--Continued

44. Vaipuna Stream at Highway crossing at Amaluia.

Location.--Lat $14^{\circ} 20^{\prime} 18^{\prime S} \mathrm{~S} .$, long $170^{\circ} 47^{\prime} 27 " \mathrm{~W} ., 100$ ft upstream of highway crossing at Amaluia and 0.6 miles northwest of Leone.

Drainage area. $--0.35 \mathrm{mi}^{2} \quad$ Tributary to.--Pacific Ocean.

Type of site.--Miscellaneous site.

Period of record. --1969.

\begin{tabular}{lcc}
\hline $\begin{array}{l}\text { Streamflow } \\
\text { characteristic }\end{array}$ & $\begin{array}{c}\text { Discharge } \\
\mathrm{ft}^{3} / \mathrm{S}\end{array}$ & $\begin{array}{c}\text { Accuracy } \\
\text { o.SE }\end{array}$ \\
\hline 7-day, 2-year low & 0.36 & 13.7 \\
7-day, 10-year low & 0.15 & 13.3 \\
Mean & 2.07 & 35.2 \\
Median & 1.24 & 21.6 \\
\hline
\end{tabular}

Basis of estimate.--Equations in table 9.

Remarks.--Base-flow index of 1.26 computed using station 16931000 as index station. Basin slope is 4,760 ft/mile. Domestic diversion above site observed in 1975.

List of measurements: total of 1 .

Date Discharge $\left(\mathrm{ft}^{3} / \mathrm{s}\right)$

05-26-69 1.40 
Table 4. Low-flow characteristics for miscellaneous sites on Tutuila, American Samoa--Continued

45. Asili stream at altitude $270 \mathrm{ft}$ at Asili.

Location.--Lat $14^{\circ} 19 \cdot 34 \mathrm{MS}$, long $170^{\circ} 47^{\prime} 40^{\prime \prime} \mathrm{W}$., at altitude $270 \mathrm{ft}$ and 0.5 mile north of Asili (revision).

Drainage area. $-0.33 \mathrm{mi}^{2} \quad$ Tributary to.--Pacific Ocean.

Type of site.--Miscellaneous site.

Period of record. --1967 .

\begin{tabular}{lcc}
\hline Streamflow & $\begin{array}{c}\text { Discharge } \\
\mathrm{ft}^{3} / \mathrm{s}\end{array}$ & $\begin{array}{c}\text { Accuracy } \\
\text { oSE }\end{array}$ \\
\hline 7-day, 2-year low & 0.38 & 34.2 \\
7-day, 10-year low & 0.17 & 37.5 \\
Mean & 2.00 & 36.5 \\
Median & 1.21 & 29.8 \\
\hline
\end{tabular}

Basis of estimate.--Equations in table 8.

Remarks. --Single measurement not base flow, so equations in table 9 not used. Gage altitude is $270 \mathrm{ft}$, basin slope is $4,900 \mathrm{ft} / \mathrm{mi}$.

List of measurements: total of 1 .

$\frac{\text { Date }}{05-25-67} \quad \frac{\text { Discharge }\left\langle\mathrm{ft}^{3} / \mathrm{s}\right\rangle}{\mathrm{a} 2.17}$

a, includes surface runoff 
Table 4. Low-flow characteristics for miscellaneous sites on Tutuila, American Samoa--Continued

46. Asili Stream at altitude $190 \mathrm{ft}$ at Asili.

Location.--Lat $14^{\circ} 19^{\prime} 41^{\prime \prime S ., ~ l o n g ~} 170^{\circ} 47^{\prime} 44^{\prime \prime} \mathrm{W} .$, at altitude $190 \mathrm{ft}$ and 0.5 mile north of Asili.

Drainage area.--0.35 $\mathrm{mi}^{2} \quad$ Tributary to.--Pacific Ocean.

Type of site.--Miscellaneous site.

Period of record.--1967, 1977-79, 1982-85, 87, 1989-90.

\begin{tabular}{lcc}
\hline $\begin{array}{l}\text { Streamflow } \\
\text { characteristic }\end{array}$ & $\begin{array}{c}\text { Discharge } \\
\mathrm{ft}^{3} / \mathrm{s}\end{array}$ & $\begin{array}{c}\text { Accuracy } \\
\frac{8}{8} \mathrm{SE}\end{array}$ \\
\hline 7-day, 2-year low & 0.30 & 27.6 \\
7-day, 10-year low & 0.14 & 50.3 \\
Mean & 1.60 & 42.3 \\
Median & 1.10 & 33.3 \\
\hline
\end{tabular}

Basis of estimate.--Graphical correlation with station 16920500 .

Remarks.--Measurements from 10-28-82 through 08-07-90 were previously published under station 16932000 heading. Site used in regional regression analysis.

List of measurements: total of 13 .

\begin{tabular}{|c|c|c|c|}
\hline Date & Discharge $\left(\mathrm{ft}^{3} / \mathrm{s}\right)$ & Date & Discharge $\left(\mathrm{ft}^{3} / \mathrm{s}\right)$ \\
\hline $05-25-67$ & $\operatorname{ac} 2.00$ & $07-12-83$ & b0 0.24 \\
\hline $07-14-77$ & a2. 50 & $08-09-83$ & b0. 18 \\
\hline $08-18-77$ & 0.43 & $08-13-85$ & $\mathrm{~b} 0.53$ \\
\hline $07-11-78$ & $\mathrm{c} 0.06$ & $06-05-87$ & $\mathrm{~b} 0.32$ \\
\hline $07-18-78$ & $\mathrm{c} 0.65$ & $08-15-89$ & $\mathrm{~b} 0.52$ \\
\hline $10-03-78$ & c0. 50 & $08-07-90$ & $\mathrm{~b} 0.33$ \\
\hline $10-28-82$ & $\mathrm{~b} 0.80$ & & \\
\hline
\end{tabular}
$a$, includes surface runoff
b, revision
C, not previously published 
Table 4. Low-flow characteristics for miscellaneous sites on Tutuila, American Samoa--Continued

47. Unnamed tributary to Asili stream at Asili.

Location.--Lat $14^{\circ} 19^{\prime} 42^{\prime \prime S ., ~ l o n g ~} 170^{\circ} 47^{\prime} 46^{\prime \prime} \mathrm{W} ., 200$ ft above confluence with Asili Stream and 0.5 mile northwest of Asili.

Drainage area.--0.17 $\mathrm{mi}^{2} \quad$ Tributary to.--Asili stream.

Type of site.--Miscellaneous site.

Period of record.--1977-79, 1983, 1987-90.

\begin{tabular}{lcc}
\hline $\begin{array}{l}\text { Streamflow } \\
\text { characteristic }\end{array}$ & $\begin{array}{c}\text { Discharge } \\
\mathrm{ft}^{3} / \mathrm{S}\end{array}$ & $\begin{array}{c}\text { Accuracy } \\
\text { oSE }\end{array}$ \\
\hline 7-day, 2-year low & 0.06 & 13.7 \\
7-day, 10-year low & 0.02 & 13.3 \\
Mean & 0.73 & 35.2 \\
Median & 0.29 & 21.6 \\
\hline
\end{tabular}

Basis of estimate.--Equations in table 9.

Remarks.--Base-flow index of 0.14 computed using 08-15-89 measurement and station 16931000 as index station. Basin slope is 6,300 ft/mile. Correlation coefficient with station 16931000 less than 0.50 so graphical correlation method was not used.

List of measurements: total of 14 .

\begin{tabular}{|c|c|c|c|}
\hline Date & Discharge $\left(\mathrm{ft}^{3} / \mathrm{s}\right)$ & Date & Discharge $\left(\mathrm{ft}^{3} / \mathrm{s}\right)$ \\
\hline$\overline{05-25-69}$ & $\operatorname{ac} 0.60$ & $07-12-83$ & 0.09 \\
\hline $07-14-77$ & $\mathrm{a} 0.60$ & $08-09-83$ & 0.08 \\
\hline $08-18-77$ & 0.09 & $06-05-87$ & 0.03 \\
\hline $07-11-78$ & c0.06 & $09-02-87$ & 0.12 \\
\hline $07-18-78$ & $\mathrm{C} 0.07$ & $09-28-88$ & 0.02 \\
\hline $10-03-78$ & $\mathrm{C} 0.21$ & $08-15-89$ & 0.02 \\
\hline $10-28-82$ & 0.24 & $08-07-90$ & 0.02 \\
\hline
\end{tabular}

a, includes surface runoff

$c$, not previously published 
Table 4. Low-flow characteristics for miscellaneous sites on Tutuila, American Samoa--Continued

48. Asili Stream at altitude 60 ft at Asili.

Location.--Lat $14^{\circ} 19^{\prime} 57^{\prime \prime S ., ~ l o n g ~} 170^{\circ} 47^{\prime} 40^{\prime \prime W}$, at altitude 60 ft and 0.2 mile north of Asili.

Drainage area. $--0.64 \mathrm{mi}^{2} \quad$ Tributary to.--Pacific Ocean.

Type of site.--Miscellaneous site.

Period of record. --1967.

\begin{tabular}{lcc}
\hline $\begin{array}{l}\text { Streamflow } \\
\text { characteristic }\end{array}$ & $\begin{array}{c}\text { Discharge } \\
\mathrm{ft}^{3} / \mathrm{s}\end{array}$ & $\begin{array}{c}\text { Accuracy } \\
\frac{\circ}{8} \mathrm{SE}\end{array}$ \\
\hline 7-day, 2-year low & 0.66 & 34.2 \\
7-day, 10-year low & 0.29 & 37.5 \\
Mean & 4.19 & 36.5 \\
Median & 2.53 & 29.8 \\
\hline
\end{tabular}

Basis of estimate.--Equations in table 8 .

Remarks.--Single measurement not base flow, so equations in table 9 not used. Gage altitude is $60 \mathrm{ft}$, basin slope is 5,920 ft/mi.

List of measurements: total of 1 .

Date Discharge $\left(\mathrm{ft}^{3} / \mathrm{s}\right)$

05-25-67 a3.26

a, includes surface runoff 
Table 4. Low-flow characteristics for miscellaneous sites on Tutuila, American Samoa--Continued

49. Fagalii Stream at Fagalii.

Location.--Lat $14^{\circ} 18^{\prime} 45^{\prime \prime S}$. long $170^{\circ} 49^{\prime} 25^{\prime \prime} \mathrm{W} ., 600$ ft upstream from mouth, and 100 ft downstream from left bank tributary (revision).

Drainage area.--0.38 $\mathrm{mi}^{2} \quad$ Tributary to.--Pacific Ocean

Type of site.--Miscellaneous site.

Period of record. --1970.

\begin{tabular}{lcc}
\hline $\begin{array}{l}\text { Streamflow } \\
\text { characteristic }\end{array}$ & $\begin{array}{c}\text { Discharge } \\
\mathrm{ft}^{3} / \mathrm{s}\end{array}$ & $\begin{array}{c}\text { Accuracy } \\
\text { osE }\end{array}$ \\
\hline 7-day, 2-year low & 0.27 & 13.7 \\
7-day, 10-year low & 0.11 & 13.3 \\
Mean & 1.95 & 35.2 \\
Median & 1.06 & 21.6 \\
\hline
\end{tabular}

Basis of estimate.--Equations in table 9 .

Remarks.--Base-flow index of 0.68 computed using station 16931000 as index station. Basin slope is 4,530 ft/mile. Domestic diversion above site observed in 1975.

List of measurements: total of 1 .

$\left.\frac{\text { Date }}{08-05-70} \quad \frac{\text { Discharge }\left(\mathrm{ft}^{3}\right.}{0.80} / \mathrm{s}\right)$ 